Prepared for the U.S. Army Corps of Engineers, Portland District,

under an Interagency Agreement with the U.S. Department of Energy

Contract DE-AC05-76RL01830

\title{
Compliance Monitoring of Yearling and Subyearling Chinook Salmon and Juvenile Steelhead Survival and Passage at John Day Dam, 2012
}

\section{FINAL COMPLIANCE REPORT}

JR Skalski

RL Townsend

AG Seaburg

MA Weiland

CM Woodley
JS Hughes

GR Ploskey

$Z$ Deng

TJ Carlson

May 2013

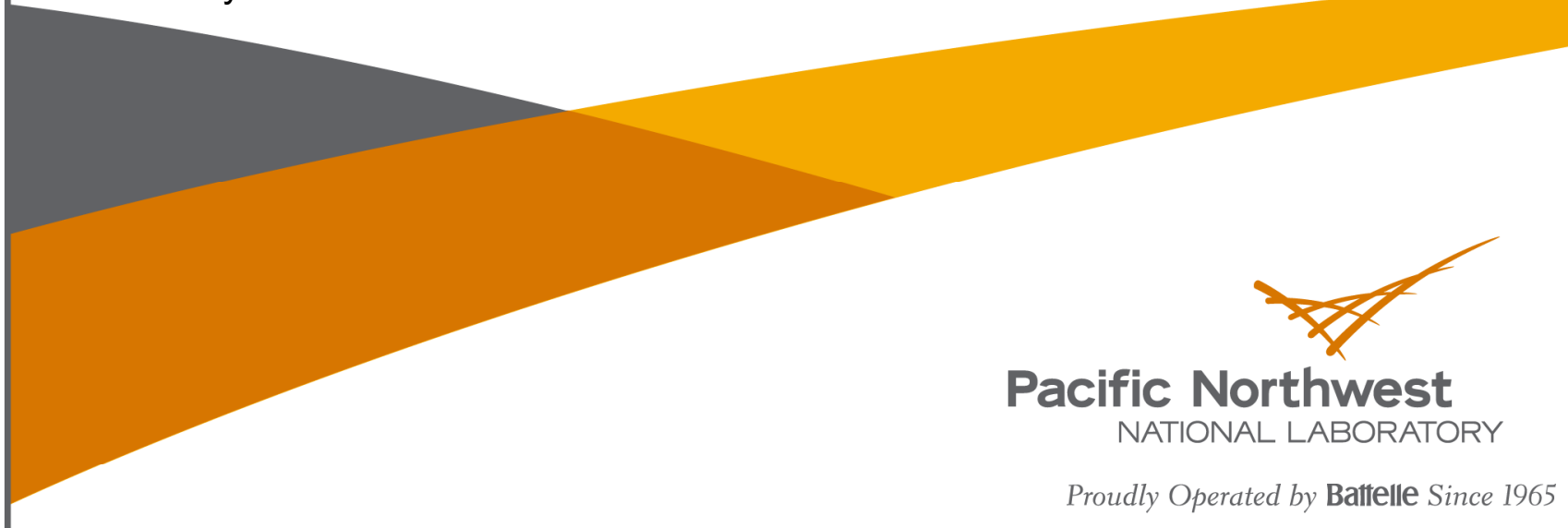




\title{
DISCLAIMER
}

This report was prepared as an account of work sponsored by an agency of the United States Government. Neither the United States Government nor any agency thereof, nor Battelle Memorial Institute, nor any of their employees, makes any warranty, express or implied, or assumes any legal liability or responsibility for the accuracy, completeness, or usefulness of any information, apparatus, product, or process disclosed, or represents that its use would not inf ringe privately owned rights. Reference herein to any specific commercial product, process, or service by trade name, trademark, manufacturer, or otherwise does not necessarily constitute or imply its endorsement, recommendation, or favoring by the United States Government or any agency thereof, or Battelle Memorial Institute. The views and opinions of authors expressed herein do not necessarily state or reflect those of the United States Government or any agency thereof.

\author{
PACIFIC NORTHWEST NATIONAL LABORATORY \\ operated by \\ BATTELLE \\ for the \\ UNITED STATES DEPARTMENT OF ENERGY \\ under Contract DE-AC05-76RL01830
}

Printed in the United States of America
Available to DOE and DOE contractors from the
Office of Scientific and Technical Information
P.O. Box 62, Oak Ridge, TN 37831-0062;
ph: (865) 576-8401
fax: $(865) 576-5728$
email: reports@adonis.osti.gov

Available to the public from the National Technical Information Service

5301 Shawnee Rd., Alexandria, VA 22312

ph: (800) 553-NTIS (6847)

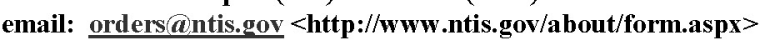

Online ordering: http://www.ntis.gov

This document was printed on recycled paper. 


\section{Compliance Monitoring of Yearling and Subyearling Chinook Salmon and Juvenile Steelhead Survival and Passage at John Day Dam, 2012}

\section{FINAL COMPLIANCE REPORT}

$\begin{array}{ll}\text { JR Skalski }^{1} & \text { JS Hughes } \\ \text { RL Townsend }^{1} & \text { GR Ploskey } \\ \text { AG Seaburg }^{1} & \text { Z Deng } \\ \text { MA Weiland } & \text { TJ Carlson } \\ \text { CM Woodley } & \end{array}$

May 2013

Prepared for

U.S. Army Corps of Engineers, Portland District under an Interagency Agreement with the U.S. Department of Energy

Contract DE-AC05-76RL01830

Pacific Northwest National Laboratory

Richland, Washington 99352

\footnotetext{
${ }^{1}$ University of Washington, Seattle, Washington.
} 


\section{Preface}

This study was conducted by the Pacific Northwest National Laboratory (PNNL) and the University of Washington (UW) for the U.S. Army Corps of Engineers, Portland District (USACE). The PNNL and UW project managers were Drs. Thomas J. Carlson and John R. Skalski, respectively. The USACE technical lead was Mr. Brad Eppard. The study was designed to estimate dam passage survival at John Day Dam as stipulated by the 2008 Federal Columbia River Power System (FCRPS) Biological Opinion (BiOp) and provide additional performance measures as specified in the Columbia Basin Fish Accords.

This report summarizes the results of the compliance studies of yearling and subyearling Chinook salmon and steelhead at John Day Dam in 2012.

Suggested citation for this report:

Skalski JR, RL Townsend, AG Seaburg, MA Weiland, CM Woodley, JS Hughes, GR Ploskey, Z Deng, and TJ Carlson. 2012. Compliance Monitoring of Yearling and Subyearling Chinook Salmon and Juvenile Steelhead Survival and Passage at John Day Dam, 2012. PNNL-22152, Pacific Northwest National Laboratory, Richland, Washington. 


\section{Executive Summary}

The purpose of this compliance study was to estimate dam passage survival of yearling and subyearling Chinook salmon and juvenile steelhead at John Day Dam during the spring and summer outmigrations in 2012. Under the 2008 Federal Columbia River Power System (FCRPS) Biological Opinion (BiOp), dam passage survival should be greater than or equal to 0.96 for spring migrants and greater than or equal to 0.93 for summer migrants, estimated with a standard error (SE) less than or equal to 0.015 . The study also estimated survival from the forebay $2 \mathrm{~km}$ upstream of the dam to the tailrace $3 \mathrm{~km}$ downstream of the dam, ${ }^{1}$ as well as the forebay residence time, tailrace egress time, spill passage efficiency (SPE), and fish passage efficiency (FPE), as required in the Columbia Basin Fish Accords (Fish Accords).

A virtual/paired-release design was used to estimate dam passage survival at John Day Dam. The approach included yearling and subyearling Chinook salmon and juvenile steelhead, tagged with acoustic micro-transmitters, released above John Day Dam that contributed to the formation of a virtual release at the face of John Day Dam. A survival estimate from this release was adjusted by a paired release below John Day Dam. A total of 3376 yearling Chinook salmon, 5726 subyearling Chinook salmon, and 3239 juvenile steelhead were used in the virtual releases. Sample sizes for the below-dam paired releases ( $R_{2}$ and $R_{3}$, respectively) were 997 and 995 for yearling Chinook salmon, 986 and 983 for subyearling Chinook salmon, and 1000 and 1000 for juvenile steelhead. The Juvenile Salmon Acoustic Telemetry System (JSATS) tags were manufactured by Advanced Telemetry Systems. Model SS300 tags, weighing $0.304 \mathrm{~g}$ in air, were surgically implanted in yearling and subyearling Chinook salmon, and Model SS130 tags, weighing $0.438 \mathrm{~g}$ in air, were surgically implanted in juvenile steelhead for this investigation.

The intent of the spring study was to estimate dam passage survival during both $30 \%$ and $40 \%$ spill conditions. The two spill conditions were to be systematically performed in alternating $2-\mathrm{d}$ test intervals over the course of the spring outmigration. High flow conditions in 2012 interrupted the spill study. Dam passage survival was therefore estimated season-wide regardless of spill conditions.

The study results are summarized in the following tables.

Table ES.1. Estimates of dam passage survival ${ }^{(a)}$ at John Day Dam in 2012.

\begin{tabular}{lccc}
\hline \multicolumn{1}{c}{ Spill Operations } & $\begin{array}{c}\text { Yearling Chinook } \\
\text { Salmon }\end{array}$ & Steelhead & $\begin{array}{c}\text { Subyearling Chinook } \\
\text { Salmon }\end{array}$ \\
\hline Season-wide spring & $0.9673(0.0065)$ & $0.9744(0.0028)^{(\mathrm{b})}$ & NA \\
Season-wide summer & NA & NA & $0.9414(0.0031)^{(\mathrm{b})}$ \\
\hline $\begin{array}{l}\text { (a) Dam passage survival is defined as survival from the upstream face of the dam to a standardized reference } \\
\text { point in the tailrace. }\end{array}$ & & \\
(b) Based on $V_{1}$ single release only. & & & \\
\hline
\end{tabular}

\footnotetext{
${ }^{1}$ The forebay-to-tailrace survival estimate satisfies the "BRZ-to-BRZ" (boat-restricted zone) survival estimate called for in the Fish Accords.
} 
Table ES.2. Fish Accords performance measures at John Day Dam in 2012. Standard errors are in parentheses.

\begin{tabular}{lccc}
\hline \multicolumn{1}{c}{ Performance Measures } & $\begin{array}{c}\text { Yearling Chinook } \\
\text { Salmon }\end{array}$ & Steelhead & $\begin{array}{c}\text { Subyearling } \\
\text { Chinook Salmon }\end{array}$ \\
\hline Forebay-to-tailrace survival (season-wide) & $0.9660(0.0065)$ & $0.9687(0.0030)^{(\mathrm{a})}$ & $0.9390(0.0032)^{(\mathrm{a})}$ \\
Forebay residence time (mean/median) & $2.50(0.14) / 1.15$ & $5.79(0.33) / 2.39$ & $2.91(0.26) / 1.02$ \\
Tailrace egress rate (mean/median) $_{\text {Spill passage efficiency }}^{(\mathrm{b})}$ & $2.80(0.28) / 0.50$ & $6.22(0.48) / 0.46$ & $2.95(0.16) / 0.48$ \\
Fish passage efficiency & $0.7456(0.0075)$ & $0.7452(0.0076)$ & $0.6962(0.0061)$ \\
\hline
\end{tabular}

(a) Based on $V_{1}$ single release only.

(b) The estimate of SPE includes temporary spill weir (TSW) and non-TSW spill bays. 
Table ES.3. Survival study summary.

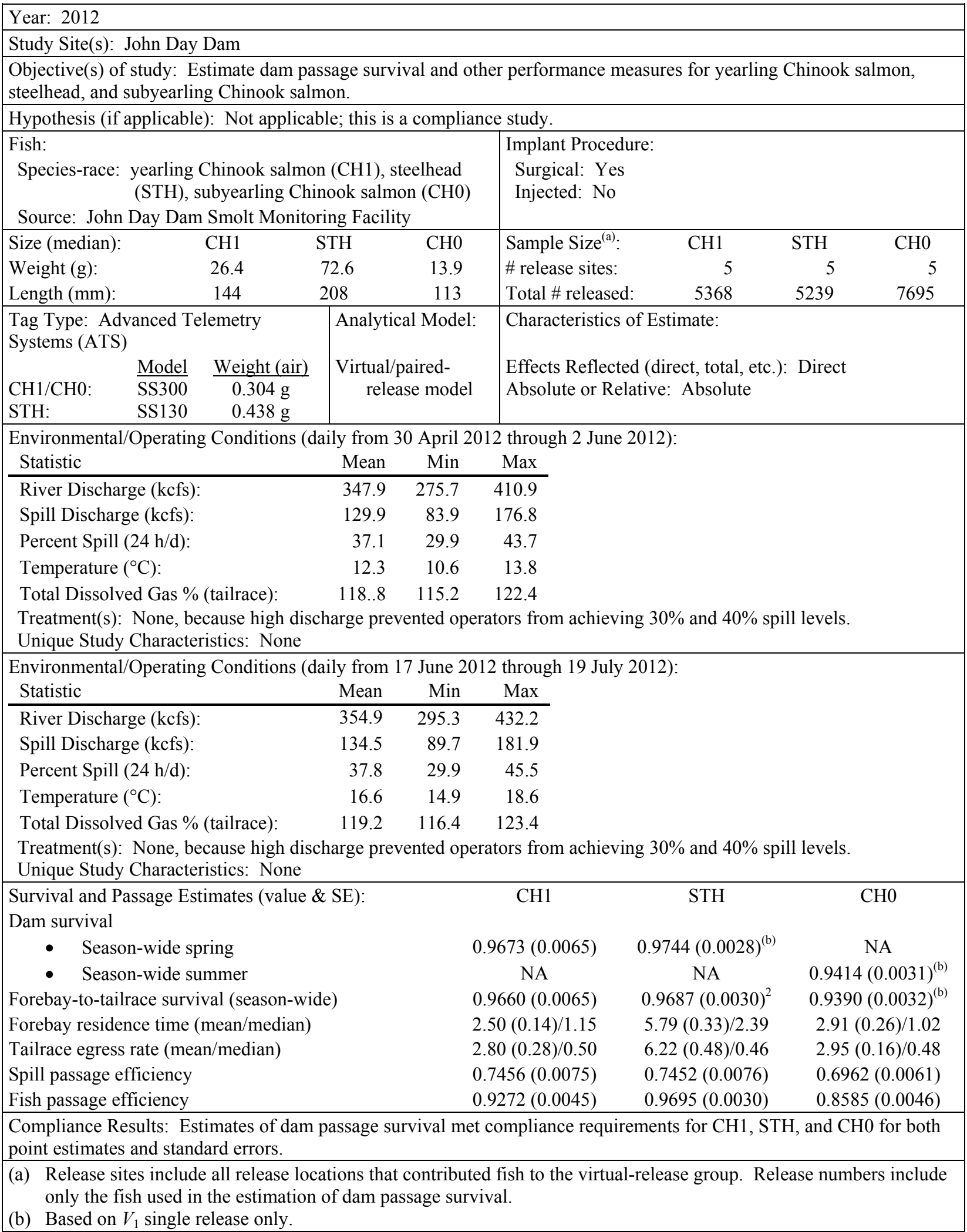




\section{Acknowledgments}

This study was the result of hard work by dedicated scientists from Cascade Aquatics, Pacific Northwest National Laboratory (PNNL), Pacific States Marine Fisheries Commission (PSMFC), the U.S. Army Corps of Engineers, Portland District (USACE), and the University of Washington (UW). Their teamwork and attention to detail, schedule, and budget were essential for the study to succeed in providing high-quality, timely results to decision-makers.

- Cascade Aquatics: B James, P James, E Anderson, C Green, E Green, J Herdman, K Martin, and H Watson

- PNNL: T Abel, C Brandt, A Bryson, E Choi, D Deng, G Dirkes, J Duncan, E Fischer, A Flory, T Fu, D Geist, M Greiner, K Hall, K Ham, R Herrington, J Horner, M Ingraham, G Johnson, R Karls, R Kaufman, F Khan, J Kim, B Lamarche, K Lavender, X Li, J Martinez, A Miracle, A Phillips, N Phillips, B Rayamajhi, G Roesijadi, D Saunders, S Southard, G Squeochs, A Thronas, N Trimble, J Varvinec, C Vernon, K Wagner, Y Yuan, and S Zimmerman

- PSMFC: R Martinson, G Kolvachuk, and D Ballenger, along with the helpful staff at John Day and Bonneville Dam Juvenile Smolt Facilities. Also we would like to thank PTAGIS and N Tancreto for her help with BON Sort-By-Code. In addition, A Ajmani, M Bahnick, A Barnes, G Batten, C Beyer, R Blanchard, S Carpenter, A Collins, A Cook, J Cox, A Cushing, L Cushing, R Davis, T Elder, D Etherington, G George, D Grugett, B Harkleroad, M Hennen, T Levandowsky, S Marvin, T Mitchell, M Neumann, G Ottoway, K Paine, K Prather, J Robertson, T Royal, G Schilperoort, G Seybert, D Spiteri, P Tramel, D Trott, R Wall, and L Wood

- USACE: B Eppard, D Schwartz, M Langeslay, and electricians, mechanics, riggers, operators, and biologists at John Day (M Zyndol, T Hurd), The Dalles (P Keller, B Cordie), and Bonneville (J Rerecich, B Hausmann, A Traylor, I Royer) dams

- UW: J Lady and P Westhagen. 


\section{Acronyms and Abbreviations}

$\begin{array}{ll}{ }^{\circ} \mathrm{C} & \text { degree(s) Celsius } \\ \text { 3D } & \text { three dimensional } \\ \text { ATS } & \text { Advanced Telemetry Systems } \\ \text { BiOp } & \text { biological opinion } \\ \text { BRZ } & \text { boat-restricted zone } \\ \text { CH0 } & \text { subyearling Chinook salmon } \\ \text { CH1 } & \text { yearling Chinook salmon } \\ \text { FCRPS } & \text { Federal Columbia River Power System } \\ \text { FPE } & \text { fish passage efficiency } \\ \text { g } & \text { gram(s) } \\ \text { h } & \text { hours(s) } \\ \text { JBS } & \text { juvenile bypass system } \\ \text { JSATS } & \text { Juvenile Salmon Acoustic Telemetry System } \\ \text { kcfs } & \text { thousand cubic feet per second } \\ \text { km } & \text { kilometer(s) } \\ \text { L } & \text { liter(s) } \\ \text { m } & \text { meter(s) } \\ \text { mg } & \text { milligram(s) } \\ \text { mm } & \text { millimeter(s) } \\ \text { PIT } & \text { passive integrated transponder } \\ \text { PNNL } & \text { Pacific Northwest National Laboratory } \\ \text { PRI } & \text { pulse repetition interval } \\ \text { PSMFC } & \text { Pacific States Marine Fisheries Commission } \\ \text { rkm } & \text { river kilometer(s) } \\ \text { RME } & \text { research, monitoring, and evaluation } \\ \text { ROR } & \text { run-of-river } \\ \text { RPA } & \text { reasonable and prudent alternative } \\ \text { s } & \text { second(s) } \\ \text { SE } & \text { standard error } \\ \text { SPE } & \text { STH } \\ \text { USACE } & \text { University of Washington } \\ \text { UW } & \end{array}$




\section{Contents}

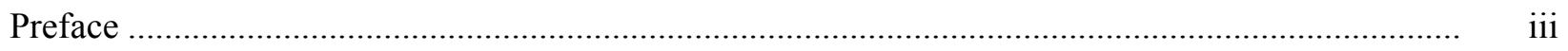

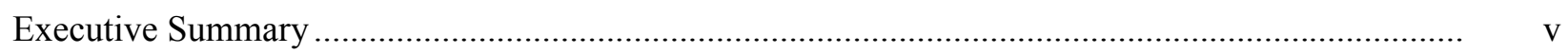

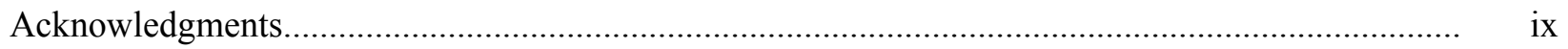

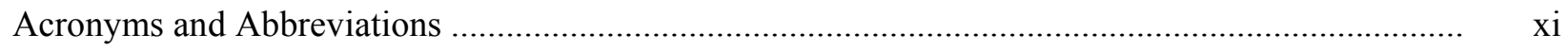

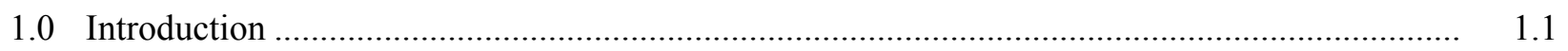

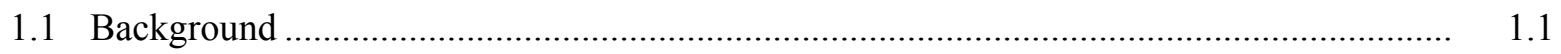

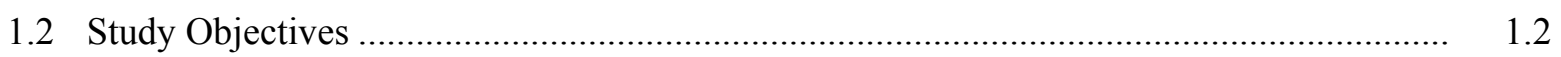

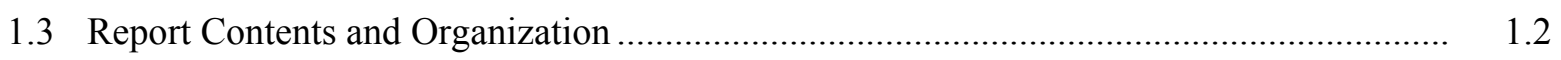

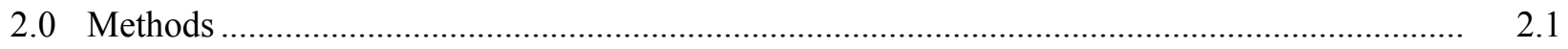

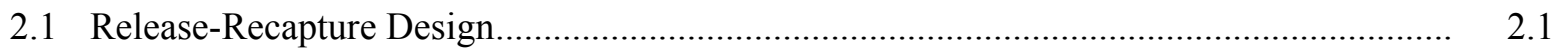

2.2 Handling, Tagging, and Release Procedures .................................................................. 2.3

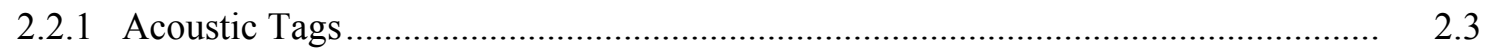

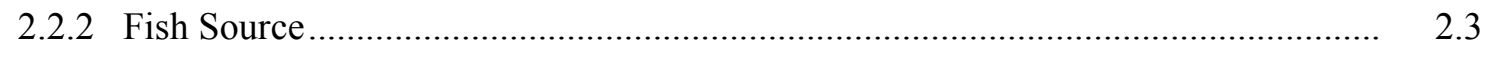

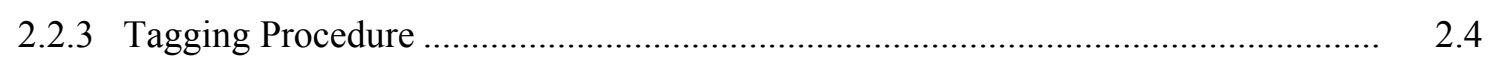

2.2.4 Release Procedures........................................................................................ 2.4

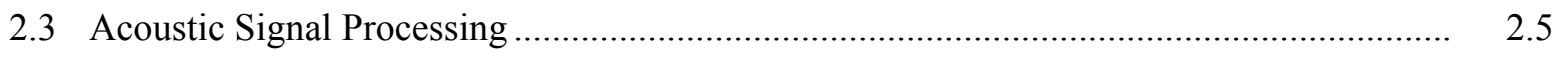

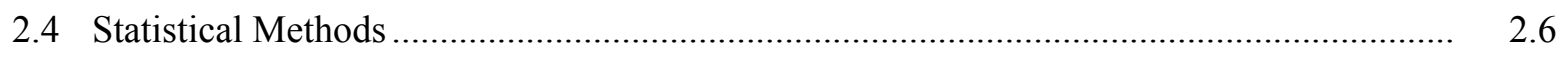

2.4.1 Estimation of Dam Passage Survival .............................................................. 2.6

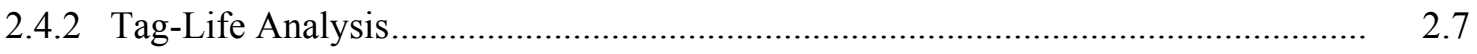

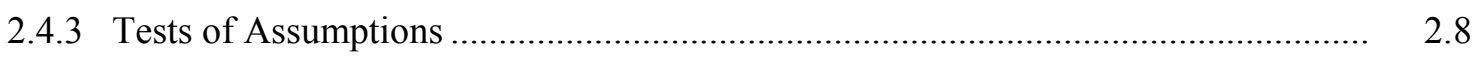

2.4.4 Forebay-to-Tailrace Survival .................................................................. 2.10

2.4.5 Estimation of Travel Times ........................................................................... 2.10

2.4.6 Estimation of Spill Passage Efficiency ........................................................... 2.10

2.4.7 Estimation of Fish Passage Efficiency ........................................................... 2.11

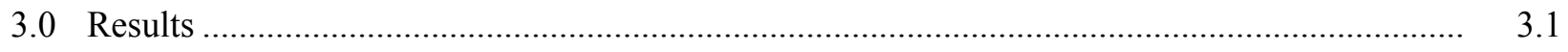

3.1 Fish Collection, Rejection, and Tagging ................................................................. 3.1

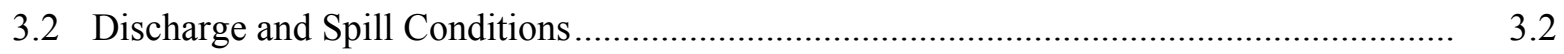

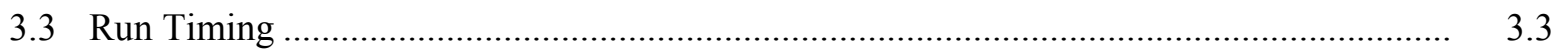

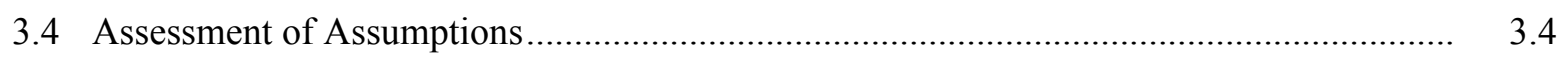

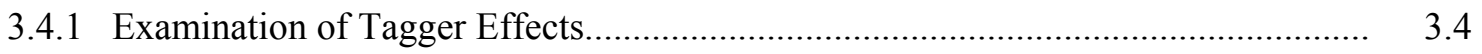

3.4.2 Examination of Tag-Lot Effects..................................................................... 3.4

3.4.3 Handling Mortality and Tag Shedding .............................................................. 3.4

3.4.4 Effects of Tailrace and Tailwater Release Locations on Survival........................... 3.4

3.4.5 Examination of Time In-River on Survivals of Different Release Groups .............. 3.8

3.4.6 Fish Size Distributions .................................................................................... 3.8

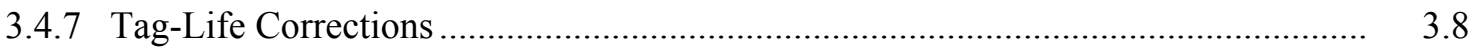




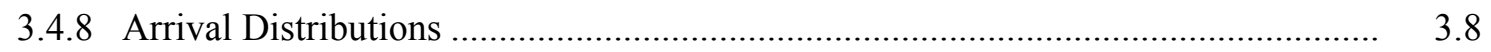

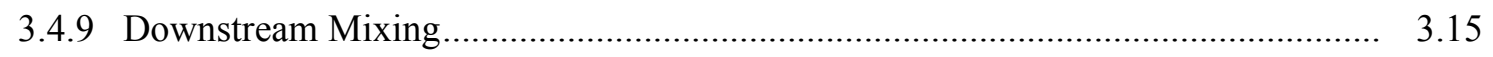

3.5 Survival and Passage Performance............................................................................ 3.17

3.5.1 Dam Passage Survival ............................................................................... 3.17

3.5.2 Forebay-to-Tailrace Passage Survival .............................................................. 3.20

3.5.3 Forebay Residence Time .............................................................................. 3.21

3.5.4 Tailrace Egress Time.................................................................................... 3.21

3.5.5 Spill Passage Efficiency ........................................................................... 3.21

3.5.6 Fish Passage Efficiency ............................................................................... 3.21

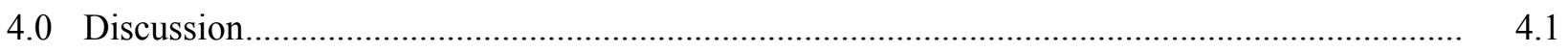

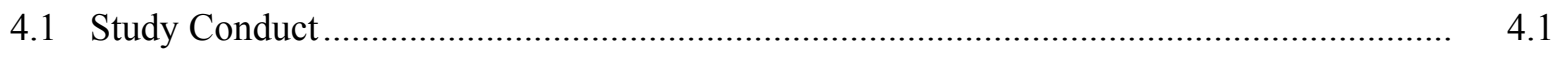

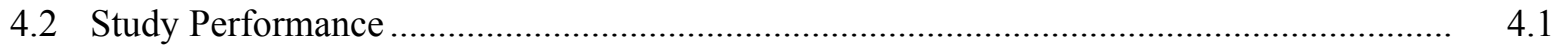

4.3 Summary of Compliance Study Results......................................................................

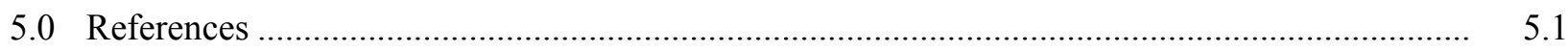

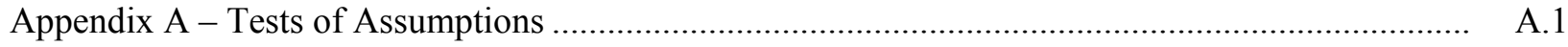

Appendix B - Capture Histories Used in Estimating Dam Passage Survival................................... B.1 


\section{Figures}

2.1 Schematic of the virtual/paired-release design used to estimate dam passage survival at John Day Dam

2.2 Front view schematic of hydrophone deployments at three turbines showing the doubledetection arrays

3.1 Daily average total discharge and percent spill at John Day Dam during the spring yearling Chinook salmon and steelhead study, 30 April to 2 June 2012, and the summer subyearling Chinook salmon study, 17 June to 19 July 2012.

3.2 Plots of the cumulative percentage of yearling Chinook salmon and steelhead that had passed John Day Dam during the spring study and subyearling Chinook salmon during the summer study of 2012

3.3 Single-release estimates of survival probabilities for yearling Chinook salmon released across the Columbia River at four or five locations from the Washington to the Oregon side of the channel.

3.4 Single-release estimates of survival probabilities for juvenile steelhead released across the Columbia River at four or five locations from the Washington to the Oregon side of the channel

3.5 Single-release estimates of survival probabilities for subyearling Chinook salmon released across the Columbia River at four or five locations from the Washington to the Oregon side of the channel

3.6 Relative frequency distributions for fish lengths of yearling Chinook salmon used in release $V_{1}$, release $R_{2}$, release $R_{3}$, and ROR fish sampled at John Day Dam by the Fish Passage Center in 2012 .

3.7 Relative frequency distributions for fish lengths of juvenile steelhead used in release $V_{1}$, release $R_{2}$, release $R_{3}$, and ROR fish sampled at John Day Dam by the Fish Passage Center in 2012

3.8 Relative frequency distributions for fish lengths of subyearling Chinook salmon used in release $V_{1}$, release $R_{2}$, release $R_{3}$, and ROR fish sampled at John Day Dam by the Fish Passage Center in 2012 during the period of the study

3.9 Range and median lengths of acoustic-tagged yearling Chinook salmon, steelhead, and subyearling Chinook salmon used over the course of the 2012 survival studies

3.10 Observed time of tag failure and fitted survivorship curves using the vitality model of Li and Anderson (2009) for yearling Chinook salmon and subyearling Chinook salmon tag lots and a three-parameter Weibull model for steelhead.....

3.11 Plots of the fitted tag-life survivorship curve and the arrival-time distributions of yearling Chinook salmon, juvenile steelhead, and subyearling Chinook salmon for releases $V_{1}, R_{2}$, and $R_{3}$ at the acoustic-detection array located at rkm 234 or rkm 275

3.12 Frequency distribution plots of downstream arrival timing for yearling Chinook salmon releases $R_{2}$ and $R_{3}$ at detection arrays located at rkm 309 and rkm 234 ......

3.13 Frequency distribution plots of downstream arrival timing for steelhead releases $R_{2}$ and $R_{3}$ at detection arrays located at rkm 309 and rkm 234

3.14 Frequency distribution plots of downstream arrival timing for subyearling Chinook salmon releases $R_{2}$ and $R_{3}$ at detection arrays located at rkm 309 and rkm 275 . 
3.15 Distribution of forebay residence times for yearling Chinook salmon, steelhead, and subyearling Chinook salmon at John Day Dam, 2012

3.16 Distribution of tailrace egress times for yearling Chinook salmon, steelhead, and subyearling Chinook salmon at John Day Dam, 2012

\section{Tables}

ES.1 Estimates of dam passage survival at John Day Dam in 2011 ........................................... v

ES.2 Fish Accords performance measures at John Day Dam in 2011 .......................................... vi

ES.3 Survival study summary ............................................................................................. vii

2.1 Sample sizes of acoustic-tagged fish releases used in the yearling and subyearling Chinook salmon and steelhead survival studies at John Day Dam in 2012 ............................ 2.3

2.2 Relative release times for acoustic-tagged fish to accommodate downstream mixing ............. 2.4

3.1 Total number of fish handled by PNNL during the spring and summer of 2012 and counts of fish in several handling categories

3.2 Number of observed malady types that warranted rejection of yearling and subyearling Chinook salmon and juvenile steelhead handled by PNNL during spring and summer of 2012

3.3 Estimated probabilities of an acoustic tag being active at a downstream detection site for yearling Chinook salmon, juvenile steelhead, and subyearling Chinook salmon by release group

3.4 Survival, detection, and $\lambda$ parameters for final model used to estimate dam passage survival for yearling Chinook salmon during the season-wide spring study....

3.5 Survival, detection, and $\lambda$ parameters for final model used to estimate dam passage survival for steelhead during the season-wide spring study ....

3.6 Survival, detection, and $\lambda$ parameters for final model used to estimate dam passage survival for subyearling Chinook during the season-wide spring study.....

3.7 Estimated mean and median forebay residence times and mean and median tailrace egress times for yearling Chinook salmon, steelhead, and subyearling Chinook salmon at John Day Dam in 2012

4.1 Summary of estimates of dam passage survival at John Day Dam from the 2011 and 2012 JSATS compliance studies 


\subsection{Introduction}

The compliance monitoring studies reported herein were conducted by researchers at the Pacific Northwest National Laboratory (PNNL) and the University of Washington for the U.S. Army Corps of Engineers, Portland District (USACE) in spring and summer 2012. The purpose of these studies was to estimate dam passage survival at John Day Dam as stipulated by the 2008 Federal Columbia River Power System (FCRPS) Biological Opinion (BiOp; NMFS 2008) and provide additional performance measures at the dam as stipulated in the Columbia Basin Fish Accords for yearling and subyearling Chinook salmon and steelhead (3 Treaty Tribes-Action Agencies 2008).

\subsection{Background}

The FCRPS 2008 BiOp contains a reasonable and prudent alternative (RPA) that includes actions calling for measurements of juvenile salmonid survival (RPAs 52.1 and 58.1). These RPAs are being addressed as part of the federal research, monitoring, and evaluation (RME) effort for the FCRPS BiOp. Most importantly, the FCRPS BiOp includes performance standards for juvenile salmonid survival in the FCRPS against which the Action Agencies (Bonneville Power Administration, Bureau of Reclamation, and USACE) must compare their estimates, as follows (after the RME Strategy 2 of the RPA):

Juvenile Dam Passage Performance Standards - The Action Agencies juvenile performance standards are an average across Snake River and lower Columbia River dams of $96 \%$ average dam passage survival for spring Chinook and steelhead and 93\% average across all dams for Snake River subyearling Chinook. Dam passage survival is defined as survival from the upstream face of the dam to a standardized reference point in the tailrace.

The Memorandum of Agreement between the three lower river tribes and the Action Agencies (known informally as the Fish Accords), contains three additional requirements relevant to the 2012 survival studies (after Attachment A to the Memorandum of Agreement):

Dam Survival Performance Standard - Meet the 96\% dam passage survival standard for yearling Chinook and steelhead and the $93 \%$ standard for subyearling Chinook. Achievement of the standard is based on 2 years of empirical survival data ....

Spill Passage Efficiency and Delay Metrics - Spill passage efficiency (SPE) and delay metrics under current spill conditions ... are not expected to be degraded ("no backsliding") with installation of new fish passage facilities at the dams ....

Future RME - The Action Agencies' dam survival studies for purposes of determining juvenile dam passage performance will also collect information about SPE, BRZ-to-BRZ (boat-restricted zone) survival and delay, as well as other distribution and survival information. Spill passage efficiency and delay metrics will be considered in the performance check-ins or with Configuration and Operations Plan updates, but not as principal or priority metrics over dam survival performance standards. Once a dam meets the survival performance standard, SPE and delay metrics may be monitored coincidentally with dam survival testing. 
This report summarizes the results of the 2012 spring acoustic-telemetry studies of yearling and subyearling Chinook salmon and steelhead at John Day Dam to assess the Action Agencies' compliance with the performance criteria of the BiOp and Fish Accords.

\subsection{Study Objectives}

The purpose of the 2012 compliance monitoring at John Day Dam was to estimate performance measures for yearling and subyearling Chinook salmon and juvenile steelhead as outlined in the FCRPS BiOp and Fish Accords. For each fish stock, the following metrics were estimated using the Juvenile Salmon Acoustic Telemetry System (JSATS) technology:

- Dam passage survival, defined as survival from the upstream face of the dam to a standardized reference point in the tailrace. Performance ${ }^{1}$ should be $\geq 96 \%$ survival for spring stocks (i.e., yearling Chinook salmon and steelhead) and $\geq 93 \%$ survival for summer stocks (i.e., subyearling Chinook salmon). Survival should be estimated with a standard error (SE) $\leq 1.5 \%$ (i.e., $95 \%$ confidence interval with half-width of $\pm 3 \% ; 3 \%=1.96 \mathrm{SE} \approx 2 \mathrm{SE}$ or $\mathrm{SE}=1.5 \%$ ).

- Forebay-to-tailrace survival, defined as survival from a forebay array $2 \mathrm{~km}$ upstream of the dam to a tailrace array $3 \mathrm{~km}$ downstream of the dam. The forebay-to-tailrace survival estimate satisfies the "BRZ-to-BRZ" survival estimated called for in the Fish Accords.

- Forebay residence time, defined as the time from first detection on the forebay entrance array, $2 \mathrm{~km}$ upstream of the dam, to the time of last detection on the dam-face array.

- Tailrace egress time, defined as the average travel time from last detection on the dam-face array to the last detection on the tailrace array $3 \mathrm{~km}$ downstream of the dam.

- Spill passage efficiency, defined as the fraction of fish going through the dam via the spillway.

- Fish passage efficiency (FPE), defined as the fraction of fish going through the dam via non-turbine routes.

The intent of the 2012 study was to assess compliance with the dam passage survival standard under alternative $30 \%$ and $40 \%$ spill conditions. The high river flow conditions during 2012 disrupted the intended spill studies. Consequently, only season-wide estimates of dam passage survival were performed.

Results are reported for the three fish stocks by performance measure. This report is designed to provide a succinct and timely summary of BiOp/Fish Accords performance measures.

\subsection{Report Contents and Organization}

The ensuing sections of this report present the study methods, results, and related discussion. The final section of the report lists references cited in the main text. The appendixes contain supplemental information about the tests of assumptions and capture-history data used in estimating dam passage survival rates.

\footnotetext{
${ }^{1}$ Performance as defined in the 2008 FCRPS BiOp, Section 6.0.
} 


\subsection{Methods}

Study methods involved fish release and recapture; the associated fish handling, tagging, and release procedures; acoustic signal processing; and statistical and analytical approaches.

\subsection{Release-Recapture Design}

The release-recapture design used to estimate dam passage survival at John Day Dam consisted of a novel combination of a virtual release $\left(V_{1}\right)$ of fish at the face of the dam and a paired release below the dam (Figure 2.1) (Skalski et al. 2010a, 2010b). Tagged fish were released above John Day Dam at three locations to supply a source of fish known to have arrived alive at the face of the dam. By releasing the fish far enough upstream, the fish should have arrived at the dam in a spatial pattern typical of run-ofriver (ROR) fish. This virtual-release group was then used to estimate survival through the dam and part of the way through the next reservoir (i.e., river kilometer [rkm] 325) (Figure 2.1). To account and adjust for this extra reach mortality, a paired release below John Day Dam (i.e., $R_{2}$ and $R_{3}$ ) (Figure 2.1) was used to estimate survival in that segment of the reservoir below the dam. Dam passage survival was then estimated as the quotient of the survival estimates for the virtual release to that of the paired release. The sizes of the releases of the fish tagged with acoustic micro-transmitters used in the dam passage survival estimates are summarized in Table 2.1.

The same release-recapture design was also used to estimate forebay-to-tailrace survival, except that the virtual-release group was constructed of fish known to have arrived at the forebay array (rkm 351). The same below-dam paired release was used to adjust for the extra release mortality below the dam as was used to estimate dam passage survival. The double-detection arrays at the face of the dam (Figure 2.2) were analyzed as two independent arrays to allow estimation of detection probabilities by route of passage and assign the location of the last detection (i.e., the passage route). These passage-route data were used to calculate SPE and FPE at John Day Dam. The fish used in the virtual release at the face of the dam were also used to estimate tailrace egress time.

One manufacturing lot of tags was used for yearling Chinook salmon, another for steelhead, and yet another tag lot for the subyearling Chinook salmon study. A total of 98 tags for yearling Chinook salmon, 100 for steelhead, and 99 for subyearling Chinook salmon were randomly sampled for the tag-life assessments. The tags were activated, held in river water, and monitored continuously until they failed. The information from the tag-life study was used to adjust the perceived survival estimates from the Cormack-Jolly-Seber release-recapture model according to the methods of Townsend et al. (2006). 


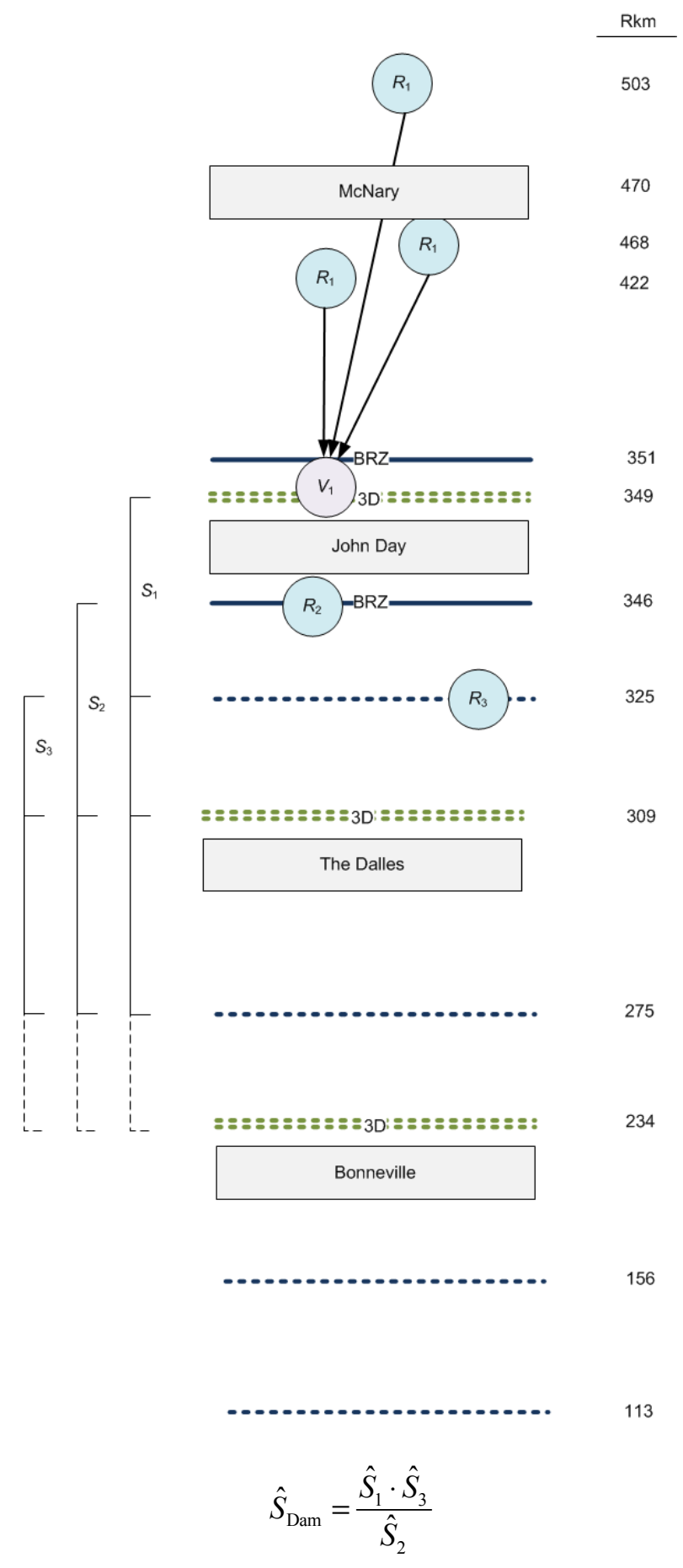

Figure 2.1. Schematic of the virtual/paired-release design used to estimate dam passage survival at John Day Dam. The virtual release $\left(V_{1}\right)$ was composed of fish that arrived at the dam face from releases at $\mathrm{rkm} 503,468$, and 422 . The below-dam release pair was composed of releases $R_{2}$ and $R_{3}$ with detection arrays used in the survival analysis denoted by dashed lines. During the spring study, the detection array at rkm 275 was unavailable. Instead, the last detection array used in the spring survival analyses was at rkm 234. 
Table 2.1. Sample sizes of acoustic-tagged fish releases used in the yearling and subyearling Chinook salmon and steelhead survival studies at John Day Dam in 2012.

\begin{tabular}{lccc}
\hline \multicolumn{1}{c}{ Release Location } & $\begin{array}{c}\text { Yearling Chinook } \\
\text { Salmon }\end{array}$ & Steelhead & $\begin{array}{c}\text { Subyearling } \\
\text { Chinook Salmon }\end{array}$ \\
\hline Above John Day Dam $\left(R_{1}\right)$ & 3797 & 3797 & 6501 \\
Virtual Release-John Day Dam $\left(V_{1}\right)$ & 3376 & 3239 & 5726 \\
John Day Dam Tailrace $\left(R_{2}\right)$ & 997 & 1000 & 986 \\
Celilo, Oregon $\left(R_{3}\right)$ & 995 & 1000 & 983 \\
\hline
\end{tabular}

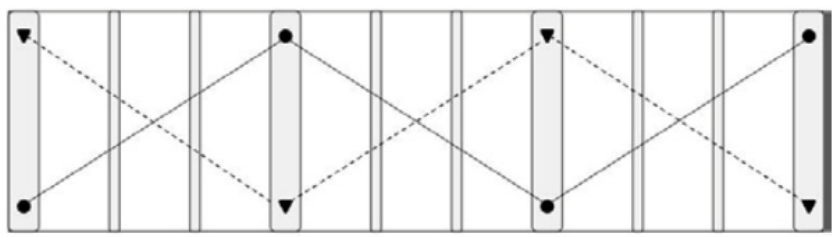

Figure 2.2. Front view schematic of hydrophone deployments at three turbines showing the doubledetection arrays. The circles denote the hydrophones of Array 1 and the triangles denote the hydrophones of Array 2.

\subsection{Handling, Tagging, and Release Procedures}

Fish obtained from the John Day Dam juvenile bypass system (JBS) were surgically implanted with both JSATS and PIT tags and transported to the different release locations, as described in the following sections.

\subsubsection{Acoustic Tags}

The acoustic tags used in the 2012 studies were manufactured by Advanced Telemetry Systems (ATS). Yearling and subyearling Chinook salmon were tagged with ATS model SS300 acoustic tags that were $10.7 \mathrm{~mm}$ long, $5.21 \mathrm{~mm}$ wide, $3.03 \mathrm{~mm}$ thick, and weighed $0.304 \mathrm{~g}$ in air. These tags had a nominal transmission rate of 1 pulse every $3 \mathrm{~s}$ and nominal tag life was expected to be about $25 \mathrm{~d}$. The ATS tag model SS130, used for juvenile steelhead, was $11.9 \mathrm{~mm}$ long, $5.1 \mathrm{~mm}$ wide, $3.7 \mathrm{~mm}$ thick, and weighed $0.438 \mathrm{~g}$ in air. This tag had a nominal transmission rate of 1 pulse every $3 \mathrm{~s}$ and nominal tag life was expected to be $33 \mathrm{~d}$.

\subsubsection{Fish Source}

The yearling and subyearling Chinook salmon and steelhead used in the studies were all obtained from the John Day Dam JBS. The Pacific States Marine Fisheries Commission diverted fish from the JBS into an examination trough, as described by Martinson et al. (2006). Fish $\geq 95$ and $<300 \mathrm{~mm}$ in length without malformations or excessive descaling $(>20 \%)$ were selected for tagging. 


\subsubsection{Tagging Procedure}

The fish to be tagged were anesthetized in an 18.9-L "knockdown" bucket that contained fresh river water and MS-222 (tricaine methanesulfonate; 80 to $100 \mathrm{mg} / \mathrm{L}$ ). Anesthesia buckets were refreshed repeatedly to maintain the temperature within $\pm 2{ }^{\circ} \mathrm{C}$ of current river temperatures. Each fish was weighed and measured before tagging.

During surgery, each fish was placed ventral side up and a gravity-fed anesthesia supply line was placed into its mouth. The dilution of the "maintenance" anesthesia was $40 \mathrm{mg} / \mathrm{L}$. Using a micro-sharp, a 5- to 7-mm incision was made in the body cavity between the pelvic girdle and pectoral fin. A passive integrated transponder (PIT) tag was inserted followed by an acoustic tag. Both tags were inserted toward the anterior end of the fish. The incision was closed using a 5-0 Monocryl suture.

After closing the incision, the fish were placed in a dark 18.9-L transport bucket filled with aerated river water. Fish were held in these buckets for 12 to $36 \mathrm{~h}$ before being transported for release into the river. The loading rate was five fish per bucket.

\subsubsection{Release Procedures}

All fish were tagged at John Day Dam and transported by truck to the release locations (Figure 2.1). Transportation routes were adjusted to provide equal travel times to each release location from John Day Dam. Upon arriving at a release site, fish buckets were transferred to a boat for transport to the in-river release location. There were five release locations at each release site across the river (Figure 2.1), and equal numbers of buckets of fish were released at each of the five locations.

Releases in the tailrace occurred for 32 consecutive days in spring (from 2 May to 2 June 2012) and another 32 consecutive days in summer (from 18 June to 19 July 2012). Upstream releases began above McNary Dam on 27 April in spring and 13 June in summer 2012, and fish were first detected on 30 April (spring) and 17 June (summer) at the $V_{1}$ array. Releases alternated between daytime and nighttime, every other day, over the course of the study. The timing of the releases at the release sites was staggered to help facilitate downstream mixing (Table 2.2).

Table 2.2. Relative release times for acoustic-tagged fish to accommodate downstream mixing. The virtual release occurred continuously from upstream release sites. Releases were timed to accommodate the approximately 6-h travel time between $R_{2}$ and $R_{3}$.

\begin{tabular}{ccc}
\hline & \multicolumn{2}{c}{ Relative Release Times } \\
\cline { 2 - 3 } Release Location & Daytime Start & Nighttime Start \\
\hline$V_{1}(\mathrm{rkm} 349)$ & Continuous & Continuous \\
$R_{2}(\mathrm{rkm} 346)$ & Day 1: 0400 & Day 2: 1600 \\
$R_{3}(\mathrm{rkm} \mathrm{325)}$ & Day 1: 1000 & Day 2: 2200 \\
\hline
\end{tabular}




\subsection{Acoustic Signal Processing}

Transmissions of JSATS tag codes received on cabled and autonomous hydrophones were recorded in raw data files. These files were downloaded periodically and transported to PNNL's North Bonneville offices for processing. Receptions of tag codes within raw data files were processed to produce a data set of accepted tag-detection events. For cabled arrays, detections from all hydrophones at a dam were combined for processing. The following three filters were used:

- Multipath filter: For data from each individual cabled hydrophone, all tag-code receptions that occur within $0.156 \mathrm{~s}$ after an initial identical tag code reception were deleted under the assumption that closely lagging signals are multipath. Initial code receptions were retained. The delay of $0.156 \mathrm{~s}$ was the maximum acceptance window width for evaluating a pulse repetition interval (PRI) and was computed as 2(PRI_Window+12×PRI_Increment). Both PRI_Window and PRI_Increment were set at $0.006 \mathrm{~s}$, which was chosen to be slightly larger than the potential rounding error in estimating PRI to two decimal places.

- Multi-detection filter: Receptions were retained only if the same tag code was received at another hydrophone in the same array within $0.3 \mathrm{~s}$ because receptions on separate hydrophones within $0.3 \mathrm{~s}$ (about $450 \mathrm{~m}$ of range) were likely from a single tag transmission.

- PRI filter: Only those series of receptions of a tag code (or "messages") that were consistent with the pattern of transmissions from a properly functioning JSATS acoustic tag were retained. Filtering rules were evaluated for each tag code individually, and it was assumed that only a single tag would be transmitting that code at any given time. For the cabled system, the PRI filter operated on a message, which included all receptions of the same transmission on multiple hydrophones within $0.3 \mathrm{~s}$. Message time was defined as the earliest reception time across all hydrophones for that message. Detection required that at least six messages were received with an appropriate time interval between the leading edges of successive messages.

The receptions of JSATS tag codes within raw data files from autonomous nodes were also processed to produce a data set of accepted tag-detection events, or events for short. A single file was processed at a time, and no information about receptions at other nodes was used. The Multipath and PRI filters described above were used.

The output of this process was a data set of events that summarized accepted tag detections for all times and locations where hydrophones were operating. Each unique event record included a basic set of fields that indicated the unique identification number of the fish, the first and last detection time for the event, the location of detection, and how many messages were detected within the event. This list was combined with accepted tag detections from the autonomous arrays and PIT-tag detections for additional quality assurance/quality control analysis prior to survival analysis. Additional fields capture specialized information, where available. One such example was route of passage, which was assigned a value for those events that immediately precede passage at a dam based on spatial tracking of tagged fish movements to a location of last detection. Multiple receptions of messages within an event can be used to triangulate successive tag position relative to hydrophone locations.

One of the most important quality control steps was to examine the chronology of detections of every tagged fish on all arrays above and below the dam-face array to identify any detection sequences that deviate from the expected upstream to downstream progression through arrays in the river. Except for 
possible detections on forebay entrance arrays after detection on a nearby dam-face array 1 to $3 \mathrm{~km}$ downstream, apparent upstream movements of tagged fish between arrays that were greater than $5 \mathrm{~km}$ apart or separated by one or more dams were very rare $(<0.015 \%)$ and probably represented false positive detections on the upstream array. False positive detections usually will have close to the minimum number of messages and were deleted from the event data set before survival analysis.

Three-dimensional (3D) tracking of JSATS-tagged fish in the immediate forebay of John Day Dam was used to determine routes of passage to estimate SPE and FPE. Acoustic tracking is a common technique in bioacoustics based on time-of-arrival differences among different hydrophones. Usually, the process requires a three-hydrophone array for two-dimensional tracking and a four-hydrophone array for $3 \mathrm{D}$ tracking. For this study, only 3D tracking was performed. The methods were similar to those described by Weiland et al. $(2009,2011,2013)$.

\subsection{Statistical Methods}

Statistical methods were used to test assumptions and estimate passage survival, tag life, forebay-totailrace survival, travel times, SPE, and FPE, as described below.

\subsubsection{Estimation of Dam Passage Survival}

Maximum likelihood estimation was used to estimate dam passage survival at John Day Dam based on the virtual/paired-release design. The capture histories from all the replicate releases, both daytime and nighttime, were pooled to produce the estimate of dam passage survival. A joint likelihood model was constructed of a product multinomial with separate multinomial distributions describing the capture histories of the separate release groups (i.e., $V_{1}, R_{2}$, and $R_{3}$ ) and differentiated by tag lot. Different tag-life adjustments were made for the different upstream releases contributing to $V_{1}$.

The joint likelihood used to model the three release groups was initially fully parameterized. Each of the three releases was allowed to have unique survival and detection parameters. If precision was adequate (i.e., $S E \leq 0.015$ ) with the fully parameterized model, no further modeling was performed. If initial precision was inadequate, then likelihood ratio tests were used to assess the homogeneity of parameters across release groups to identify the best parsimonious model to describe the capture-history data. This approach was used to help preserve both precision and robustness of the survival results. All calculations were performed using Program ATLAS (http://www.cbr.washington.edu/paramest/atlas/).

Dam passage survival was estimated by the function

$$
\hat{S}_{\text {Dam }}=\frac{\hat{S}_{1}}{\left(\frac{\hat{S}_{2}}{\hat{S}_{3}}\right)}=\frac{\hat{S}_{1} \cdot \hat{S}_{3}}{\hat{S}_{2}}
$$

where $\hat{S}_{i}$ is the tag-life-corrected survival estimate for the $i$ th release group $(i=1, \ldots, 3)$. The variance of $\hat{S}_{\text {Dam }}$ was estimated in a two-step process that incorporated both the uncertainty in the tag-life corrections and the release-recapture processes. 
In 2012, compliance tests at John Day Dam were planned for dam operation conditions that included alternating 2-d test intervals of either $30 \%$ or $40 \%$ spill during both spring and summer studies. However, because of high river discharge in 2012 , the spill conditions of $30 \%$ or $40 \%$ spill could not be achieved. Therefore, dam passage survival was estimated season-wide, including all days regardless of spill conditions.

\subsubsection{Tag-Life Analysis}

For each tag lot of JSATS tags, 98, 100, and 99 acoustic tags were systematically sampled over the course of the yearling Chinook salmon, juvenile steelhead, and subyearling Chinook salmon tagging studies, respectively. The tags were continuously monitored from activation to failure in ambient river water. For each tag lot, the failure times were fit to either the four-parameter vitality model of Li and Anderson (2009) or a three-parameter Weibull distribution. The vitality model tends to fit acoustic-tag failure times well, as it allows for both early onset of random failure due to manufacturing as well as systematic battery failure later on. In the case of the steelhead, no early onset failures occurred.

Consequently, the three-parameter Weibull distribution was used to model tag life for the steelhead study.

The survivorship function for the vitality model can be rewritten as

$$
S(t)=1-\left(\Phi\left(\frac{1-r t}{\sqrt{u^{2}+s^{2} t}}\right)-e^{\left(\frac{2 u^{2} r^{2}}{s^{4}}+\frac{2 r}{s^{2}}\right)} \Phi\left(\frac{2 u^{2} r+r t+1}{\sqrt{u^{2}+s^{2} t}}\right)\right)^{e^{-k t}}
$$

where $\Phi=$ cumulative normal distribution

$r=$ average wear rate of components

$s=$ standard deviation in wear rate

$k=$ rate of accidental failure

$u=$ standard deviation in quality of original components.

The random failure component, in addition to battery discharge, gives the vitality model additional latitude to fit tag-life data not found in other failure-time distributions such as the Weibull or Gompertz. Parameter estimation was based on maximum likelihood estimation.

The three-parameter Weibull distribution (Elandt-Johnson and Johnson 1980:62) with scale $(\lambda)$, shape $(\beta)$, and shift $(\gamma)$ parameters has the following probability density function

$$
f(t)=\frac{\beta}{\lambda}\left(\frac{t-\gamma}{\lambda}\right)^{\beta-1} e^{-\left(\frac{t-\gamma}{\lambda}\right)^{\beta}}
$$

with survivorship function

$$
S(t)=e^{-\left(\frac{t-\gamma}{\lambda}\right)^{\beta}}
$$


cumulative density function (CDF)

$$
F(t)=1-e^{-\left(\frac{t-\gamma}{\lambda}\right)^{\beta}}
$$

and hazard function

$$
h(t)=\frac{\beta}{\lambda}\left(\frac{t-\gamma}{\lambda}\right)^{\beta-1} .
$$

The three-parameter Weibull reduces to the two-parameter Weibull when $\gamma=0$; it reduces to the exponential distribution when $\beta=1$ and $\gamma=0$.

For the virtual-release group $\left(V_{1}\right)$ based on fish known to have arrived at the dam and with active tags, the conditional probability of tag activation, given the tag was active at the detection array at rkm 349 , was used in the tag-life adjustment for that release group. The conditional probability of tag activation at time $t_{1}$, given it was active at time $t_{0}$, was computed by the quotient:

$$
P\left(t_{1} \mid t_{0}\right)=\frac{S\left(t_{1}\right)}{S\left(t_{0}\right)}
$$

where $S\left(t_{0}\right)$ is the average unconditional probability that the tag is active when detected at the $V_{1}$ detection array ( $\mathrm{rkm} 349$ ), and $S\left(t_{1}\right)$ is the average unconditional probability that the tag is active when detected at the first downstream survival detection array ( $\mathrm{rkm} 325)$.

\subsubsection{Tests of Assumptions}

Approaches to assumption testing are described below.

\subsubsection{Burnham et al. (1987) Tests}

Tests 2 and 3 of Burnham et al. (1987) have been used to assess whether upstream detection history has an effect on downstream survival. Such tests are most appropriate when fish are physically recaptured or segregated during capture as in the case with PIT-tagged fish going through the JBS. However, acoustic-tag studies do not use physical recaptures to detect fish. Consequently, there is little or no relevance of these tests in acoustic-tag studies. Furthermore, the very high detection probabilities present in acoustic-tag studies frequently preclude calculation of these tests. For these reasons, these tests were not performed. 


\subsubsection{Tests of Mixing}

Evaluation of homogeneous arrival of release groups at downriver detection sites was based on graphs of arrival distributions. The graphs were used to identify any systematic and meaningful departures from mixing. Ideally, the arrival distributions should overlap one another with similarly timed modes.

\subsubsection{Tagger Effects}

Subtle differences in handling and tagging techniques can have an effect on the survival of juvenile salmonids used in the estimation of dam passage survival. For this reason, tagger effects were evaluated. The single release-recapture model was used to estimate reach survivals for fish tagged by different individuals. The analysis evaluated whether any consistent pattern of reduced reach survivals existed for fish tagged by any of the tagging staff.

For $k$ independent reach survival estimates, a test of equal survival was performed using the $F$-test

$$
F_{k-1, \infty}=\frac{s_{\hat{S}}^{2}}{\left(\frac{\left.\sum_{i=1}^{k} \widehat{\operatorname{Var}}\left(\hat{S}_{i} \mid S_{i}\right)\right)}{k}\right)}
$$

where

$$
s_{\hat{S}}^{2}=\frac{\sum_{i=1}^{k}\left(\hat{S}_{i}-\hat{\bar{S}}\right)^{2}}{k-1}
$$

and

$$
\hat{\bar{S}}=\frac{\sum_{i=1}^{k} \hat{S}_{i}}{k}
$$

The $F$-test was used in evaluating tagger effects as well as delayed tag effects.

\subsubsection{Delayed Tag Effects}

The fish forming the virtual-release group (i.e., $V_{1}$ ) came from multiple upstream release locations. If delayed effects of handling or tagging occurred, this could affect the performance of the virtual-release group. Consequently, downstream reach survivals and cumulative release survivals are compared among fish released at different upstream locations. The $F$-test (2.4) evaluates whether reach survivals are homogeneous regardless of release location. Should heterogeneity be detected, uppermost release groups might be eliminated from subsequent survival and other analyses. 


\subsubsection{Tag-Lot Effects}

Because only one tag lot was used per survival analysis, examination of tag-lot effects was unnecessary.

\subsubsection{Forebay-to-Tailrace Survival}

The same virtual/paired-release methods used to estimate dam passage were also used to estimate forebay-to-tailrace survival. The only distinction was the virtual-release group $\left(V_{1}\right)$ was composed of fish known to have arrived alive at the forebay array (rkm 351) of John Day Dam instead of at the dam face (Figure 2.1).

\subsubsection{Estimation of Travel Times}

Travel times associated with forebay residence time and tailrace egress were estimated using arithmetic averages as specified in the Fish Accords, i.e.,

$$
\bar{t}=\frac{\sum_{i=1}^{n} t_{i}}{n}
$$

with the variance of $\bar{t}$ estimated by

$$
\widehat{\operatorname{Var}}(\bar{t})=\frac{\sum_{i=1}^{n}\left(t_{i}-\bar{t}\right)^{2}}{n(n-1)},
$$

and where $t_{i}$ was the travel time of the $i^{\text {th }}$ fish $(i=1, \ldots, n)$. Median travel times were also computed and reported.

The estimated tailrace egress time was based on the time from last detection of a fish at the double array at the dam face at John Day Dam to the last detection at the tailrace array $3 \mathrm{~km}$ downstream of the dam ( $\mathrm{rkm} 346)$. The estimated forebay residence times were based on the time from the first detection at the forebay BRZ array $2 \mathrm{~km}$ above the dam to the last detection at the double array on the upstream face of John Day Dam.

\subsubsection{Estimation of Spill Passage Efficiency}

Spill passage efficiency was estimated by the fraction

$$
\widehat{\mathrm{SPE}}=\frac{\hat{N}_{N T S W}+\hat{N}_{T S W}}{\hat{N}_{N T S W}+\hat{N}_{T S W}+\hat{N}_{T U R}+\hat{N}_{J B S}}
$$

where $\hat{N}_{i}$ is the estimated abundance of acoustic-tagged fish through the $i$ th route $(i=$ non-TSW [NTSW], temporary spill weir [TSW], turbines [TUR], and juvenile bypass system [JBS]). The 
double-detection array was used to estimate absolute abundance $(N)$ through a route using the single mark-recapture model (Seber 1982:60) independently at each route. Calculating the variance in stages, the variance of $\widehat{\mathrm{SPE}}$ was estimated as

$$
\begin{aligned}
\operatorname{Var}(\widehat{\mathrm{SPE}})= & \frac{\widehat{\mathrm{SPE}}(1-\widehat{\mathrm{SPE}})}{\sum_{i=1}^{4} \hat{N}_{i}}+\widehat{\mathrm{SPE}}^{2}(1-\widehat{\mathrm{SPE}})^{2} \\
& \cdot\left[\frac{\operatorname{Var}\left(\hat{N}_{N T S W}\right)+\operatorname{Var}\left(\hat{N}_{T S W}\right)}{\left(\hat{N}_{N T S W}+\hat{N}_{T S W}\right)^{2}}+\frac{\widehat{\operatorname{Var}}\left(\hat{N}_{T U R}\right)+\operatorname{Var}\left(\hat{N}_{J B S}\right)}{\left(\hat{N}_{T U R}+\hat{N}_{J B S}\right)^{2}}\right] .
\end{aligned}
$$

\subsubsection{Estimation of Fish Passage Efficiency}

Fish passage efficiency was estimated by the fraction

$$
\widehat{\mathrm{FPE}}=\frac{\hat{N}_{N T S W}+\hat{N}_{T S W}+\hat{N}_{J B S}}{\hat{N}_{N T S W}+\hat{N}_{T S W}+\hat{N}_{J B S}+\hat{N}_{T U R}}
$$

Calculating the variance in stages, the variance of $\widehat{\mathrm{FPE}}$ was estimated as

$$
\begin{aligned}
\operatorname{Var}(\widehat{\mathrm{FPE}})= & \frac{\widehat{\mathrm{FPE}}(1-\widehat{\mathrm{FPE}})}{\sum_{i=1}^{4} \hat{N}_{i}}+\widehat{\mathrm{FPE}}^{2}(1-\widehat{\mathrm{FPE}})^{2} \\
& \cdot\left[\frac{\operatorname{Var}\left(\hat{N}_{N T S W}\right)+\operatorname{Var}\left(\hat{N}_{T S W}\right)+\operatorname{Var}\left(\hat{N}_{J B S}\right)}{\left(\hat{N}_{N T S W}+\hat{N}_{T S W}+\hat{N}_{J B S}\right)^{2}}+\frac{\widehat{\operatorname{Var}}\left(\hat{N}_{T U R}\right)}{\hat{N}_{T U R}^{2}}\right] .
\end{aligned}
$$




\subsection{Results}

The results cover four topics: 1) fish collection, rejection, and tagging; 2) discharge and spill conditions; 3) tests of assumptions; and 4) survival and passage estimates.

\subsection{Fish Collection, Rejection, and Tagging}

The total number of fish handled by PNNL in 2012 and the counts and percentages of fish by handling category are listed in Table 3.1. During the study, 29,645 yearling and subyearling Chinook salmon and juvenile steelhead were handled.

Table 3.1. Total number of fish handled by PNNL during the spring and summer of 2012 and counts of fish in several handling categories.

\begin{tabular}{cccrrrr}
\hline Handling Category & CH1 & \%CH1 & STH & \%STH & CH0 & \%CH0 \\
\hline Retained for Tagging & 6555 & 96.3 & 6515 & 93.0 & 15,328 & 96.8 \\
Non-Candidate based on Condition & 253 & 3.7 & 494 & 7.0 & 500 & 3.2 \\
\hline Total Handled & $\mathbf{6 8 0 8}$ & \multicolumn{5}{c}{$\mathbf{1 5 , 8 2 8}$} \\
\hline CH1 = yearling Chinook salmon, STH = juvenile steelhead, CH0 = subyearling Chinook salmon. \\
\hline
\end{tabular}

Staff rejecting fish from tagging recorded the reasons by tallying the maladies observed (Table 3.2). Conditions were based on the general recommendations of the Columbia Basin Rejection Criteria (CBSPSC 2011) and confirmed by the Studies Review Work Group and National Oceanic and Atmospheric Administration in meetings during spring 2012 (B Eppard, personal communication, April 20, 2012). PNNL broadened the criteria to accept more fish. Fish were not accepted for the project if they were moribund, or showed obvious signs of progressed infections/diseases (e.g., fungus or furunculosis presence greater than $5 \%$ on one side of fish flank), open wounds that perforated the body cavity, skeletal deformities that would inhibit tag insertion or swimming ability, and descaling greater than $20 \%$ where there is no indication of scale growth or slime coat present. If more than $5 \%$ of the sample the day before had a particular malady/infection, the following day fish with that malady were accepted after approval by the fish condition study manager.

Table 3.2. Number of observed malady types that warranted rejection of yearling and subyearling Chinook salmon and juvenile steelhead handled by PNNL during spring and summer of 2012.

\begin{tabular}{lrrrrrrr}
\hline & CH1 & \% CH1 & STH & \% STH & CH0 & \% CH0 & Total \\
\hline Descaling $>20 \%$ & 65 & 25.7 & 139 & 28.1 & 139 & 27.8 & $\mathbf{3 4 3}$ \\
Caudal Fin Missing & 8 & 3.2 & 1 & 0.2 & 8 & 1.6 & $\mathbf{1 7}$ \\
Diseases & 107 & 42.3 & 274 & 55.5 & 197 & 39.4 & $\mathbf{4 3}$ \\
Damage/Injury & 88 & 34.8 & 141 & 28.5 & 213 & 42.6 & $\mathbf{4 4 2}$ \\
Skeletal Deformity & 16 & 6.3 & 21 & 4.3 & 6 & 1.2 & $\mathbf{5 7 8}$ \\
\hline Total Fish $^{\text {(a) }}$ & $\mathbf{2 5 3}$ & & $\mathbf{4 9 4}$ & & $\mathbf{5 0 0}$ & & $\mathbf{1 2 4 7}$ \\
\hline
\end{tabular}

(a) Each species averaged $>1$ malady per fish; $11.5 \%$ for $\mathrm{CH} 1,15.9 \%$ for $\mathrm{STH}$, and $10.8 \%$ for $\mathrm{CH} 0$ of fish for each species had more than one malady.

$\mathrm{CH} 1=$ yearling Chinook salmon, $\mathrm{STH}=$ juvenile steelhead, $\mathrm{CH} 0=$ subyearling Chinook salmon . 


\subsection{Discharge and Spill Conditions}

High river discharge during spring and summer 2012 prevented formation of the intended $2-\mathrm{d} 30 \%$ or $40 \%$ spill test intervals (Figure 3.1). Dam passage survival was therefore calculated season-wide during the prevailing conditions of spill (i.e., $\geq 30 \%$ ) over the entire period.

a. Spring

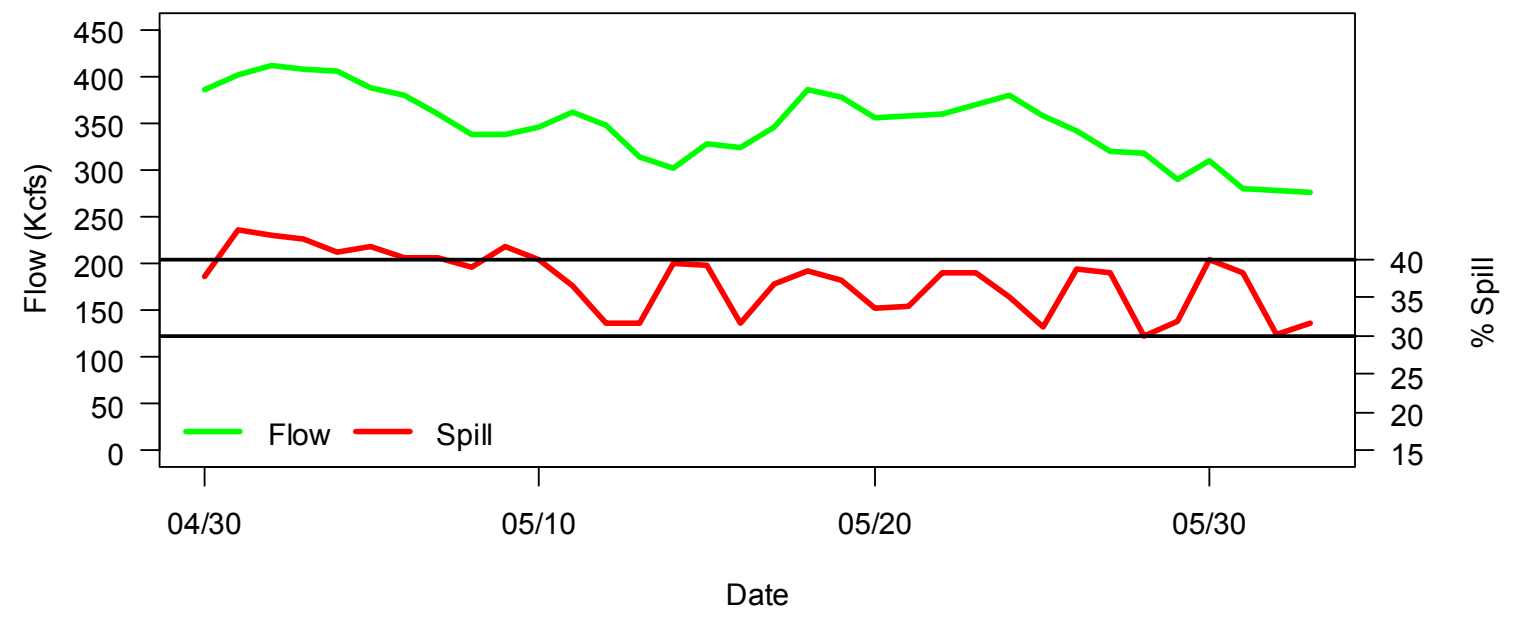

b. Summer

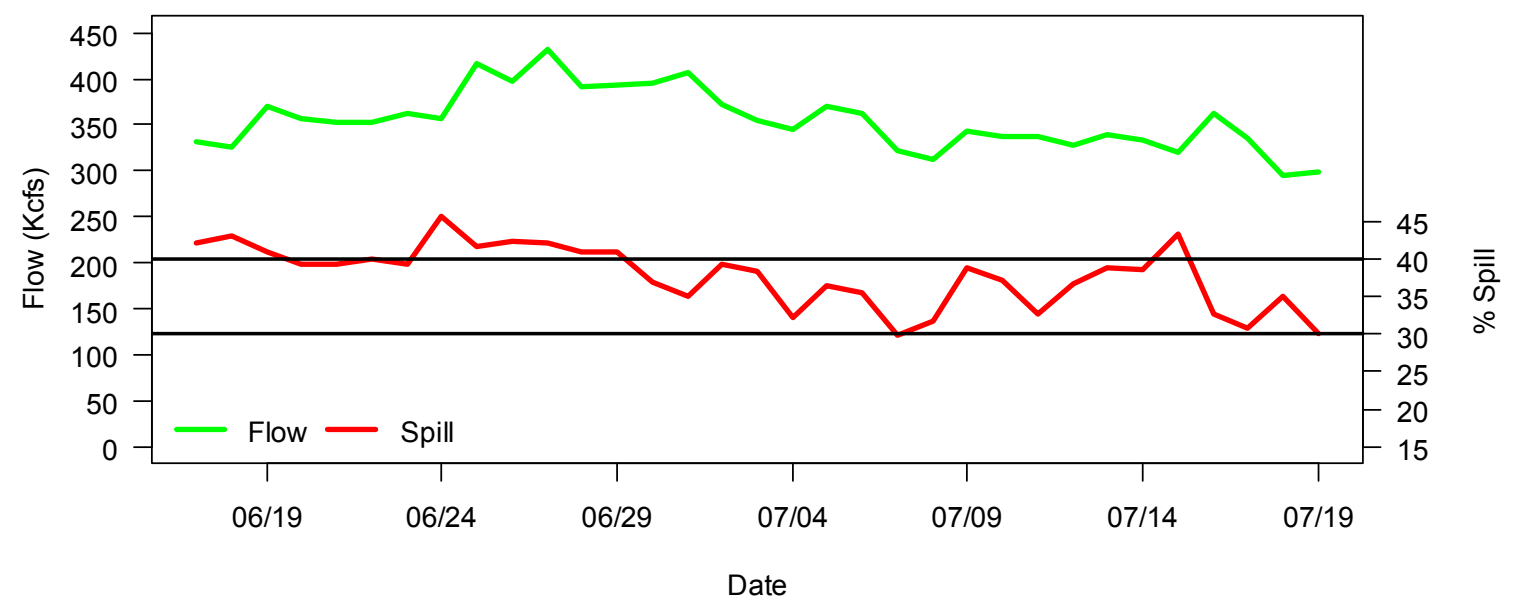

Figure 3.1. Daily average total discharge and percent spill at John Day Dam during a) the spring yearling Chinook salmon and steelhead study, 30 April to 2 June 2012, and b) the summer subyearling Chinook salmon study, 17 June to 19 July 2012. 


\subsection{Run Timing}

The cumulative percentage of yearling Chinook salmon, juvenile steelhead, and subyearling Chinook that had passed John Day Dam by date was calculated from smolt index data obtained from the Fish Passage Center (Figure 3.2). Over the period of the study, from April 30 through June 2, 2012, 89.7\% of yearling Chinook salmon and $65.2 \%$ of juvenile steelhead had passed John Day Dam. By the end of the study on June 2, 2012, 98.1\% of yearling Chinook salmon and $98.3 \%$ of juvenile steelhead relative to the total run had passed John Day Dam. Over the period of the study, from June 17 through July 19, 2012, 63.8\% of subyearling Chinook salmon had passed John Day Dam. By the end of the study on July 19, 2012, 66.5\% of subyearling Chinook salmon had passed John Day Dam relative to the total run.

a. Spring

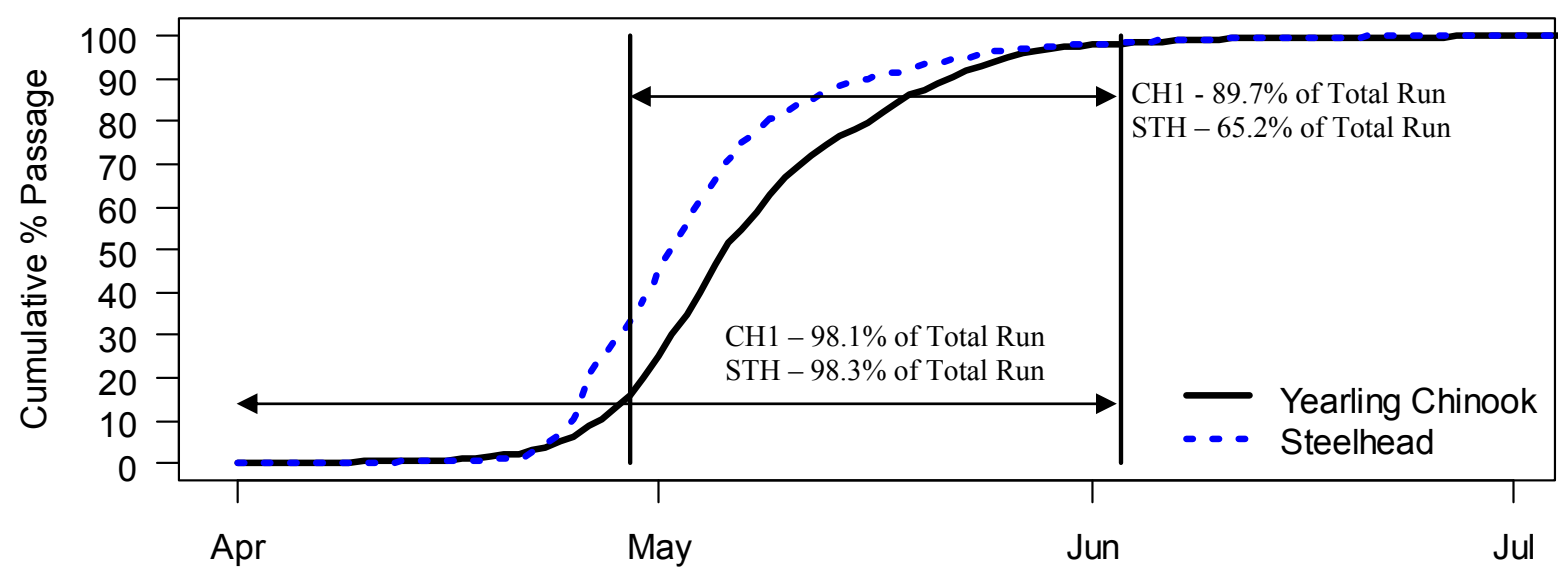

Date

b. Summer

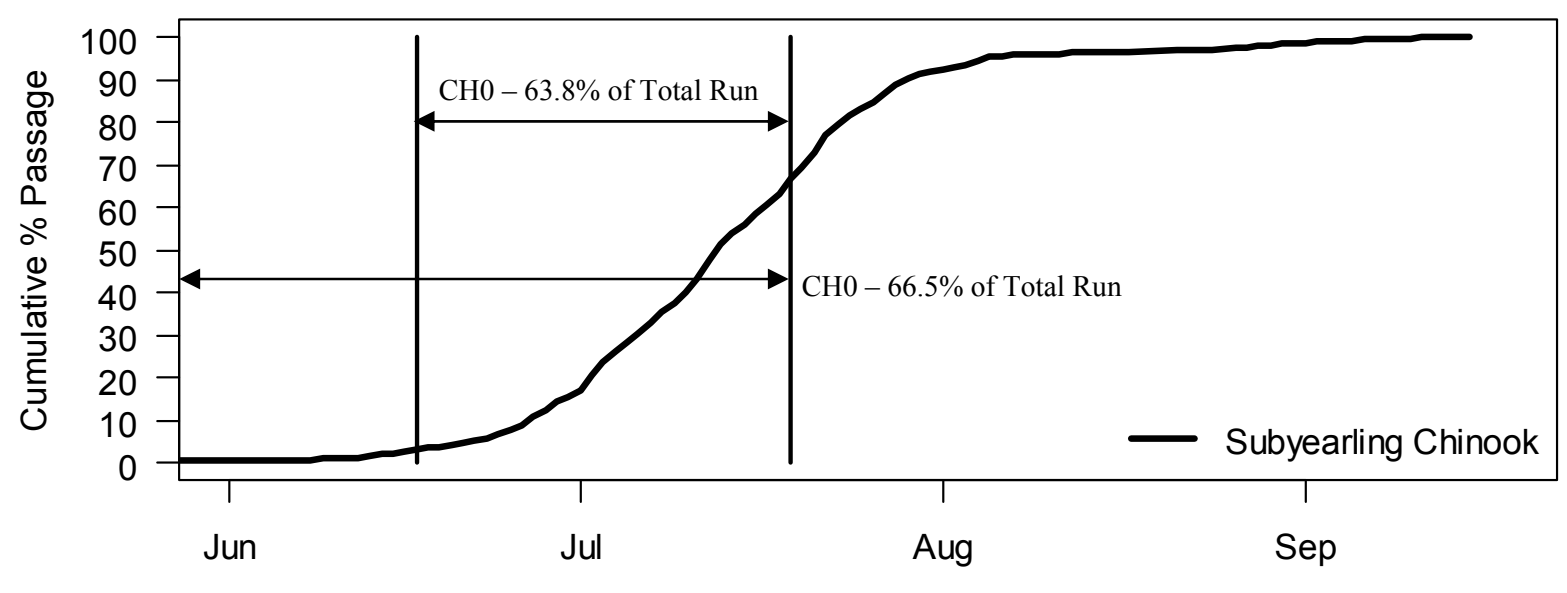

Date

Figure 3.2. Plots of the cumulative percentage of a) yearling Chinook salmon and steelhead that had passed John Day Dam during the spring study and b) subyearling Chinook salmon during the summer study of 2012. Vertical lines mark the beginning and end of the survival studies. 


\subsection{Assessment of Assumptions}

The assessment of assumptions covers tagger effects, tag-lot effects, delayed handling effects, fish size distributions, tag-life corrections, arrival distributions, and downstream mixing.

\subsubsection{Examination of Tagger Effects}

A total of eight different taggers assisted in tagging all yearling and subyearling Chinook salmon and juvenile steelhead associated with the JSATS survival studies at McNary, John Day, The Dalles, and Bonneville dams in spring and summer 2012. Analyses found tagger effort was homogeneously distributed either across all locations within a replicate release or within the project-specific releases within a replicate (Appendix A). Examination of reach survivals and cumulative survivals from above McNary Dam to below Bonneville Dam found no consistent or repeatable evidence that fish tagged by different staff members had different in-river survival rates (Appendix A). Therefore, fish tagged by all taggers were included in the estimation of survival and other performance measures.

\subsubsection{Examination of Tag-Lot Effects}

One tag lot was used for the spring yearling Chinook salmon study, another for the spring steelhead study, and yet another for the summer subyearling Chinook salmon study. Therefore, examination of taglot effects was unnecessary.

\subsubsection{Handling Mortality and Tag Shedding}

Fish were held for 12 to $36 \mathrm{~h}$ prior to release. The post-tagging mortality in spring was $0.27 \%$ and $0.02 \%$ for yearling Chinook salmon and steelhead, respectively. One PIT tag was shed during the posttagging holding period in spring. In summer, post-tagging mortality was $0.18 \%$ for subyearling Chinook salmon and no tags were shed.

\subsubsection{Effects of Tailrace and Tailwater Release Locations on Survival}

Survival rates for yearling Chinook salmon, steelhead, and subyearling Chinook salmon released at four or five adjacent locations across the John Day Dam tailrace and tailwater did not appear to differ significantly based upon overlap of 95\% confidence intervals (Figure 3.3, Figure 3.4, and Figure 3.5, respectively). The uppermost plot in each of the figures shows survival rates for dam-passed fish regrouped on tailrace autonomous nodes to form four virtual releases across the tailrace. Regrouping dam-passed fish $\left(V_{1}\right)$ on the tailrace array is problematic because it has the real potential to include some tagged fish that died during dam passage, which would violate survival model assumptions and underestimate survival in downstream reaches. Our intent was to provide some indication of the relative distribution of survival rates for fish regrouped at sites across the tailrace and not to provide robust estimates of dam-passage survival. An underlying assumption is that the probability of regrouping dead fish along with live fish is low and similar across the tailrace, but this assumption may not be valid.

The distribution of numbers of fish released at five locations across the tailrace release site was uniform, as was the distribution of numbers of fish released at five sites across the tailwater release site (see numbers and percentages in the middle and bottom plots in Figure 3.3, Figure 3.4, and Figure 3.5). 
We did not specify the number of $V_{1}$ fish regrouped on each autonomous node because that distribution can be highly biased by differences in tag detectability, which is inversely related to linear water velocity where each node was deployed.

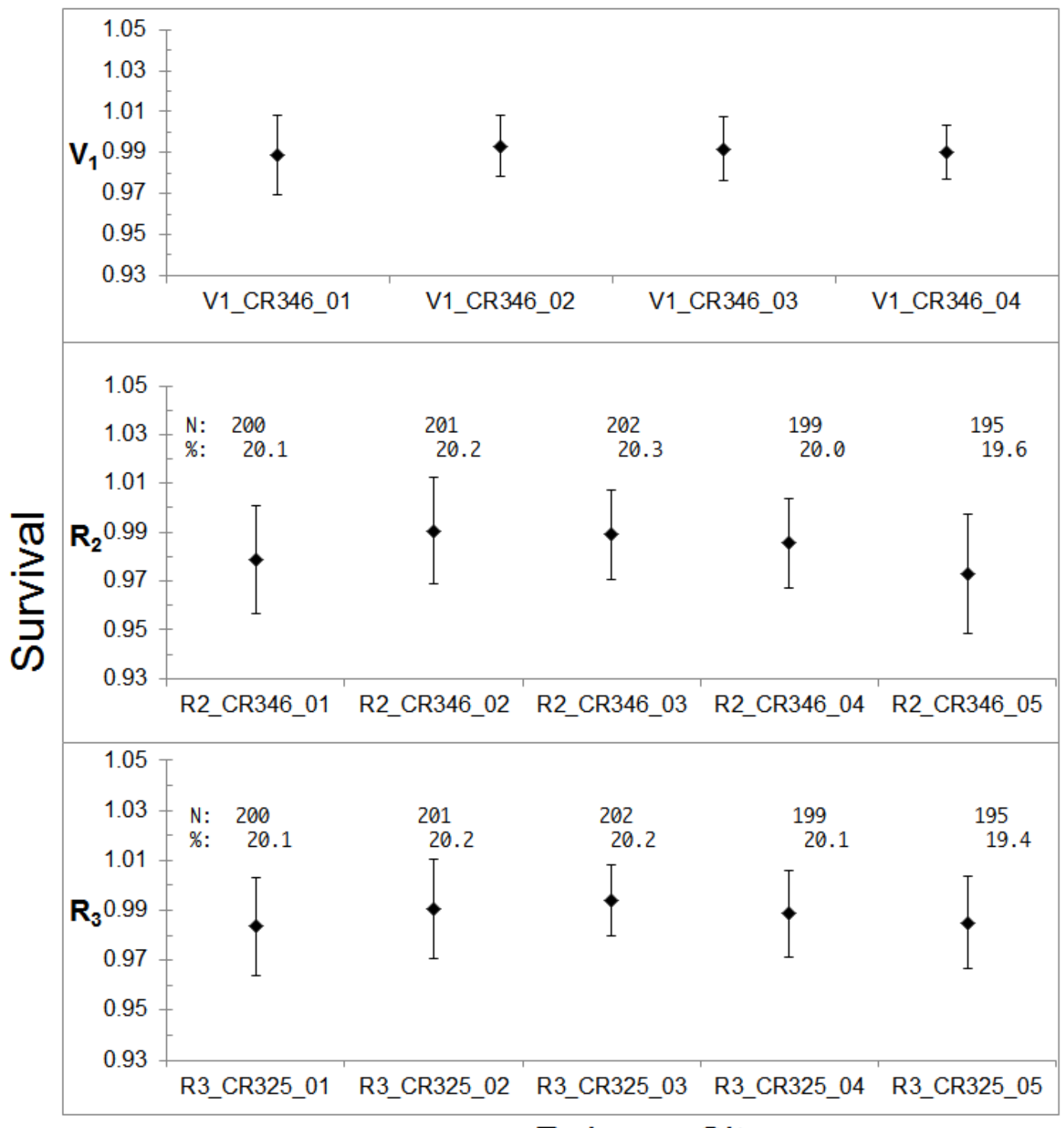

\section{Release Site}

Figure 3.3. Single-release estimates of survival probabilities (y axis) for yearling Chinook salmon released across the Columbia River at four or five locations from the Washington to the Oregon side of the channel (x axis). The top plot shows survival probabilities for the reach from CR346 to CR325 for four virtual releases of fish formed by regrouping dam-passed fish on the tailrace autonomous node that received the most receptions of a tag code. The middle plot shows reach survival probabilities for $R_{2}$ fish (John Day Dam-tailrace releases at CR346) to The Dalles Dam (CR309), and the bottom plot shows reach survivals for $R_{3}$ fish released in the John Day Dam tailwater near Celilo, Oregon (CR325), after travel to The Dalles Dam (CR309). Two lines of numbers across survival bars show the number $(\mathrm{N})$ and percent of fish released at each location. Vertical error bars represent the extent of the $95 \%$ confidence interval. 


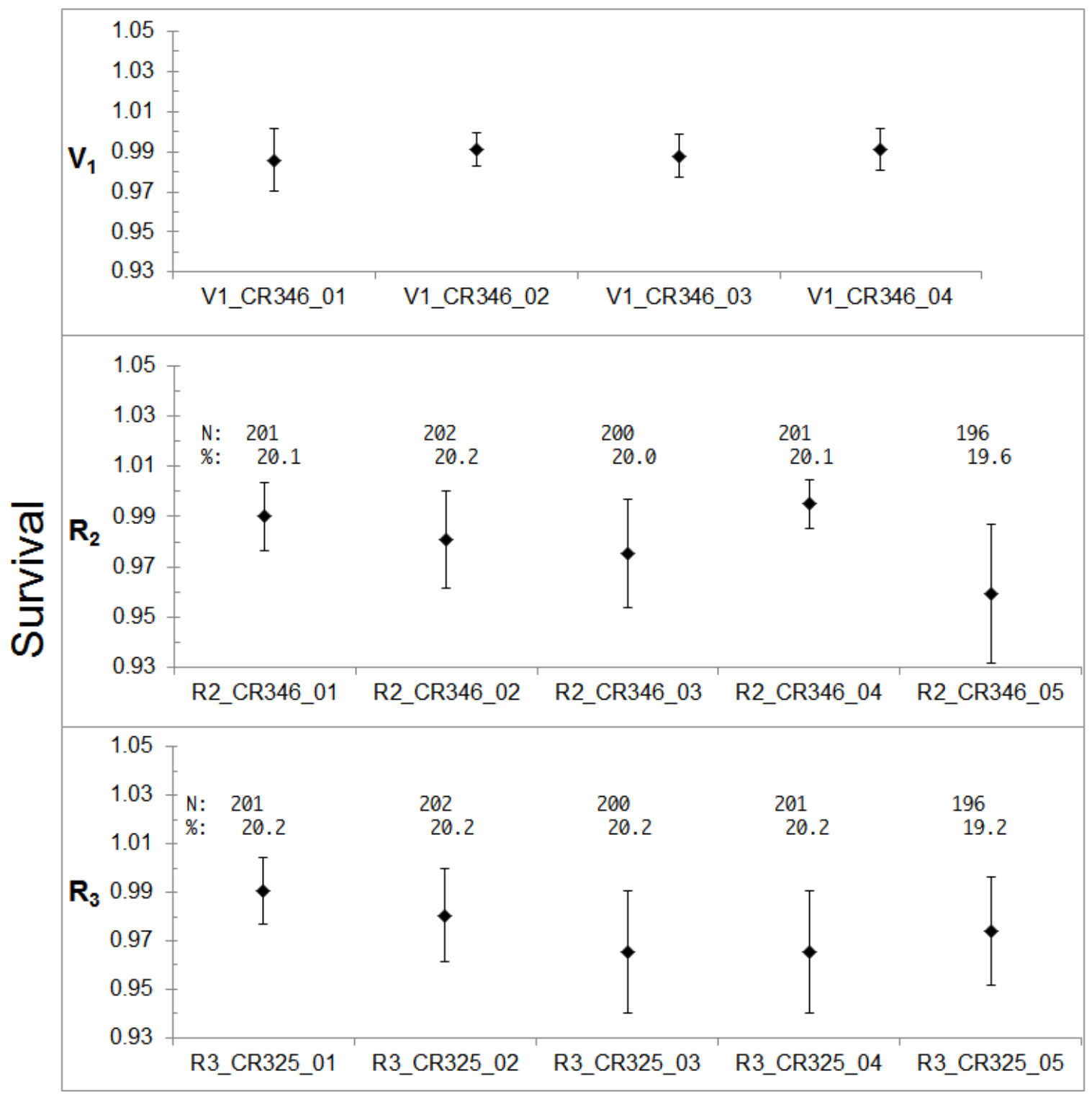

Release Site

Figure 3.4. Single-release estimates of survival probabilities (y axis) for juvenile steelhead released across the Columbia River at four or five locations from the Washington to the Oregon side of the channel (x axis). The top plot shows survival probabilities for the reach from CR346 to CR325 for four virtual releases of fish formed by regrouping dam-passed fish on the tailrace autonomous node that received the most receptions of a tag code. The middle plot shows reach survival probabilities for $R_{2}$ fish (John Day Dam-tailrace releases at CR346) to The Dalles Dam (CR309), and the bottom plot shows reach survivals for $R_{3}$ fish released in the John Day Dam tailwater near Celilo, Oregon (CR325), after travel to The Dalles Dam (CR309). Two lines of numbers across survival bars show the number $(\mathrm{N})$ and percent of fish released at each location. Vertical error bars represent the extent of the $95 \%$ confidence interval. 


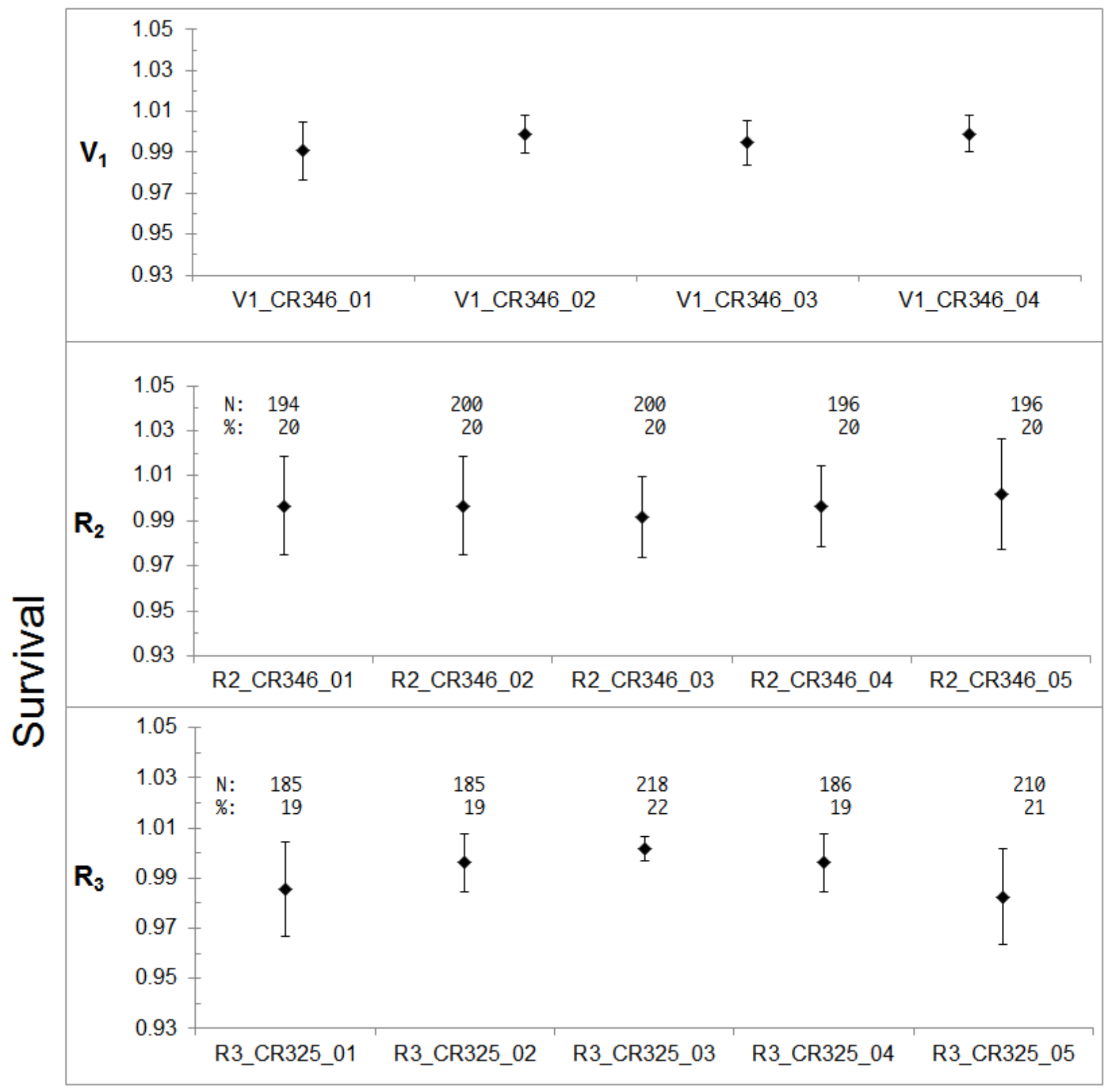

\section{Release Site}

Figure 3.5. Single-release estimates of survival probabilities (y axis) for subyearling Chinook salmon released across the Columbia River at four or five locations from the Washington to the Oregon side of the channel (x axis). The top plot shows survival probabilities for the reach from CR346 to CR325 for four virtual releases of fish formed by regrouping dam-passed fish on the tailrace autonomous node that received the most receptions of a tag code. The middle plot shows reach survival probabilities for $R_{2}$ fish (John Day Dam -tailrace releases at CR346) to The Dalles Dam (CR309), and the bottom plot shows reach survivals for $R_{3}$ fish released in the John Day Dam tailwater near Celilo, Oregon (CR325), after travel to The Dalles Dam (CR309). Two lines of numbers across survival bars show the number of fish (N) and percent of fish released at each site. Vertical error bars represent the extent of the $95 \%$ confidence interval. 


\subsubsection{Examination of Time In-River on Survivals of Different Release Groups}

The virtual release formed from the detections of upriver releases at the face of the dam could result in biased survival estimates if fish from varying upriver release locations had differential downriver survival rates (Figure 2.1). For this reason, reach survivals and cumulative survivals were compared across fish from different upriver release locations. There was no consistent or reproducible evidence to suggest that the amount of time (i.e., distance) in-river had a subsequent effect on downriver survival for either yearling Chinook salmon or juvenile steelhead (Appendix A). There was evidence for subyearling Chinook salmon that the uppermost releases could not be used at Bonneville Dam. However, in constructing the virtual releases at the face of John Day Dam, fish from all available upriver release locations were used in subsequent survival and other parameter estimation.

\subsubsection{Fish Size Distributions}

Comparison of JSATS-tagged fish with ROR fish sampled at John Day Dam through the Smolt Monitoring Program shows that the length frequency distributions were generally well matched for yearling Chinook salmon (Figure 3.6), steelhead (Figure 3.7), and subyearling Chinook salmon (Figure 3.8). The length distributions for the three yearling Chinook salmon releases (Figure 3.6), the three steelhead releases (Figure 3.7), and the three subyearling Chinook salmon releases (Figure 3.8) also were quite similar. Mean lengths for the acoustic-tagged yearling Chinook salmon were $143.9 \mathrm{~mm}$; for the steelhead, $206.7 \mathrm{~mm}$; and for the subyearling Chinook salmon, $112.9 \mathrm{~mm}$. Mean lengths for yearling Chinook salmon, steelhead, and subyearling Chinook salmon sampled by the Fish Passage Center at the John Day Dam juvenile sampling facility were $143.3 \mathrm{~mm}, 201.2 \mathrm{~mm}$, and $109.4 \mathrm{~mm}$, respectively. Fish size did not change over the course of the study for yearling Chinook salmon or steelhead (Figure 3.9). For subyearling Chinook salmon, size shifted ever so slightly smaller as the season progressed.

\subsubsection{Tag-Life Corrections}

During 2012, separate tag lots were used for each fish stock in the spring and summer studies. From each of these tag lots, 98 to 100 tags were systematically sampled to conduct independent tag-life studies. A 3-parameter Weibull curve was used to fit the tags used in the steelhead study, and the vitality curve of Li and Anderson (2009) was used to fit the yearling Chinook salmon spring study and the subyearling Chinook salmon summer study Figure 3.10). Average tag lives were $32.2 \mathrm{~d}, 23.0 \mathrm{~d}$, and $23.3 \mathrm{~d}$ for the steelhead, yearling Chinook salmon, and summer subyearling Chinook salmon tag lots, respectively.

\subsubsection{Arrival Distributions}

The estimated probability an acoustic tag was active when fish arrived at a downstream detection array depends on the tag-life curve and the distribution of observed travel times for yearling Chinook salmon, steelhead, and subyearling Chinook salmon (Figure 3.11). Examination of the fish arrival distributions to the last detection array used in the survival analyses indicated all fish that arrived had passed through the study area before tag failure became important. These probabilities were calculated by integrating the tag survivorship curve (Figure 3.11) over the observed distribution of fish arrival times (i.e., time from tag activation to arrival). The probabilities of a JSATS tag being active at a downstream detection site were specific to release location and season (Table 3.3). In all cases, the probability a tag was active at a downstream detection site as far as rkm 234 for yearling Chinook salmon was 0.9943 and 1.0000 for juvenile steelhead (Table 3.3). For subyearling Chinook salmon, the probability of an acoustic tag being active at rkm 275 was 0.9979 . 
a. John Day Dam (Release $\left.V_{1}\right)$

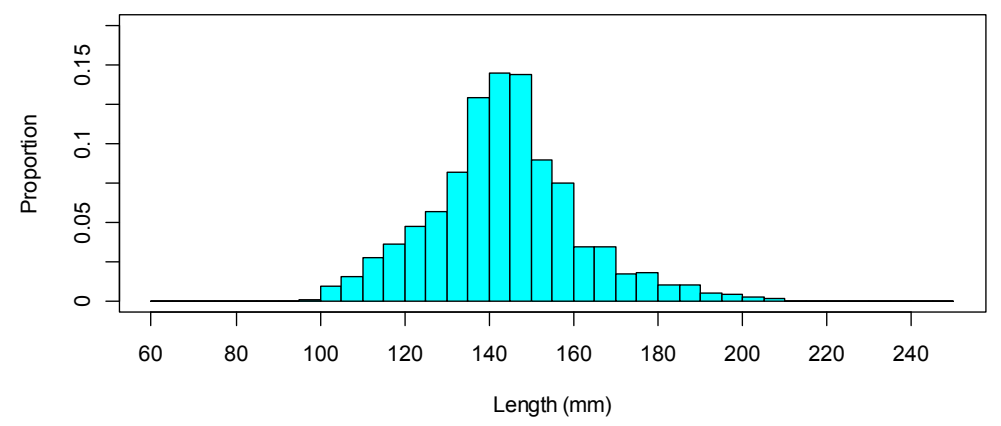

b. John Day Tailrace (Release $R_{2}$ )

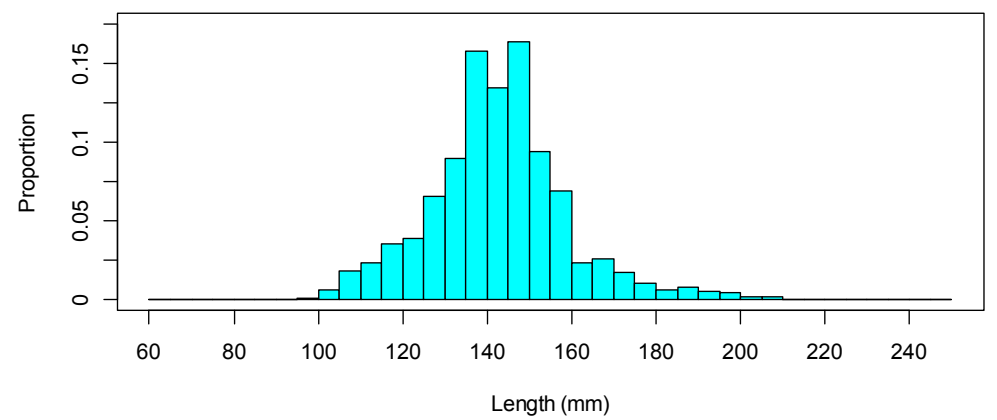

c. John Day Tailwater (Release $R_{3}$ )

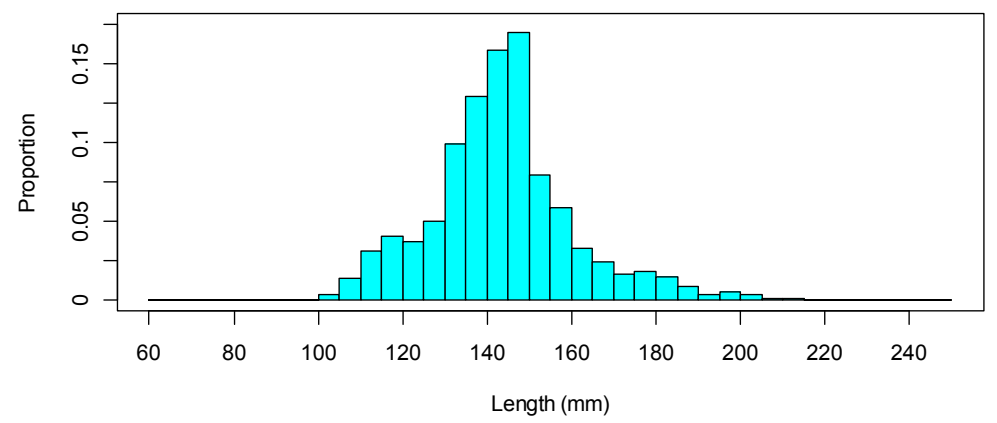

d. ROR Yearling Chinook Salmon at John Day Dam

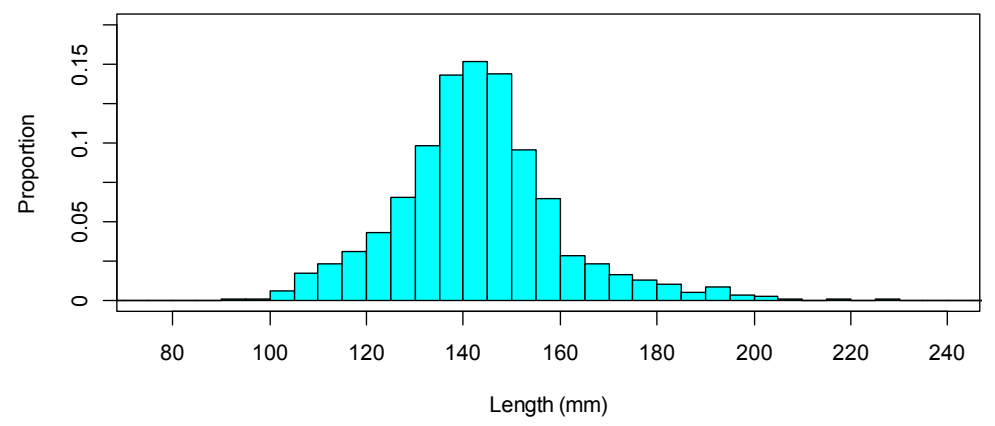

Figure 3.6. Relative frequency distributions for fish lengths $(\mathrm{mm})$ of yearling Chinook salmon used in a) release $V_{1}$, b) release $R_{2}$, c) release $R_{3}$, and d) ROR fish sampled at John Day Dam by the Fish Passage Center in 2012. 
a. John Day Dam (Release $\left.V_{1}\right)$

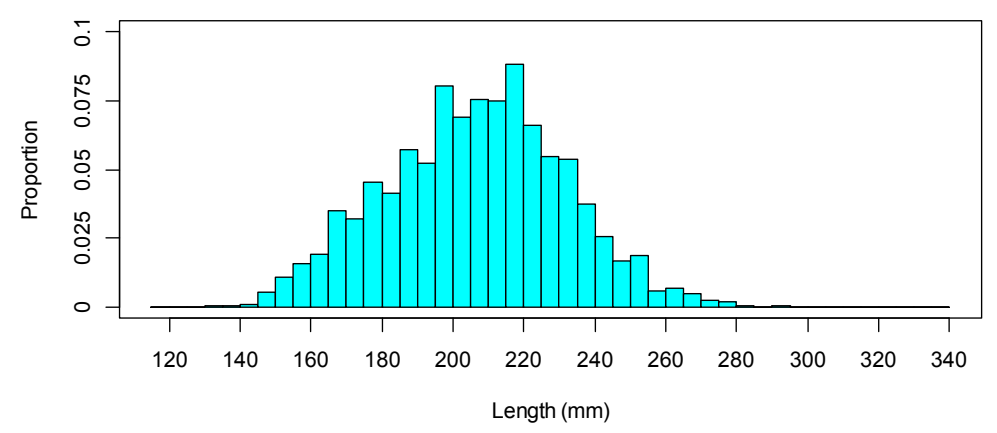

b. John Day Tailrace (Release $R_{2}$ )

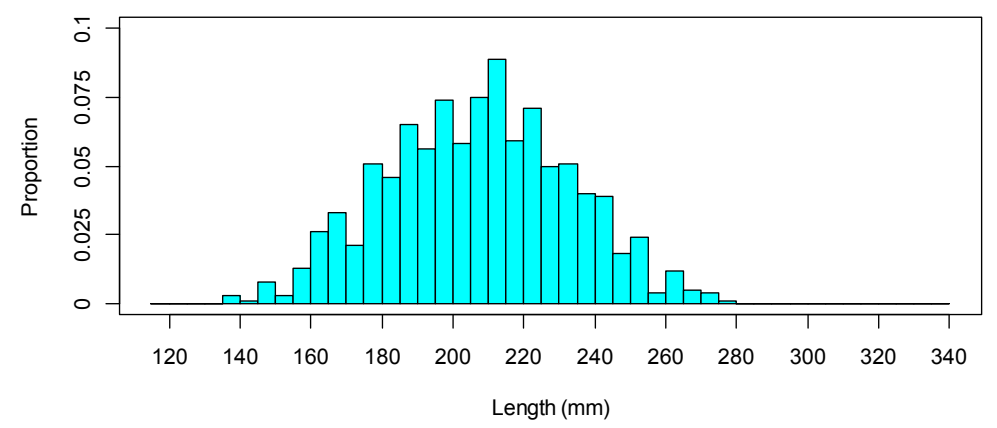

c. John Day Tailwater (Release $R_{3}$ )

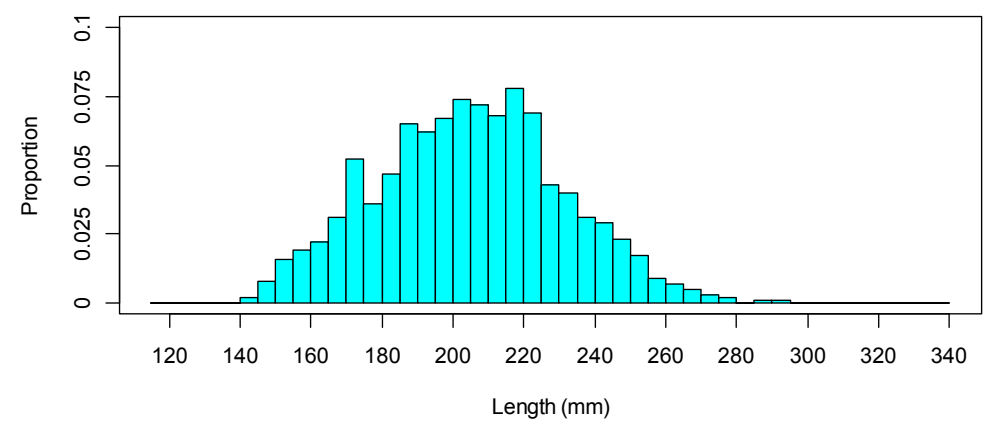

d. ROR Juvenile Steelhead at John Day Dam

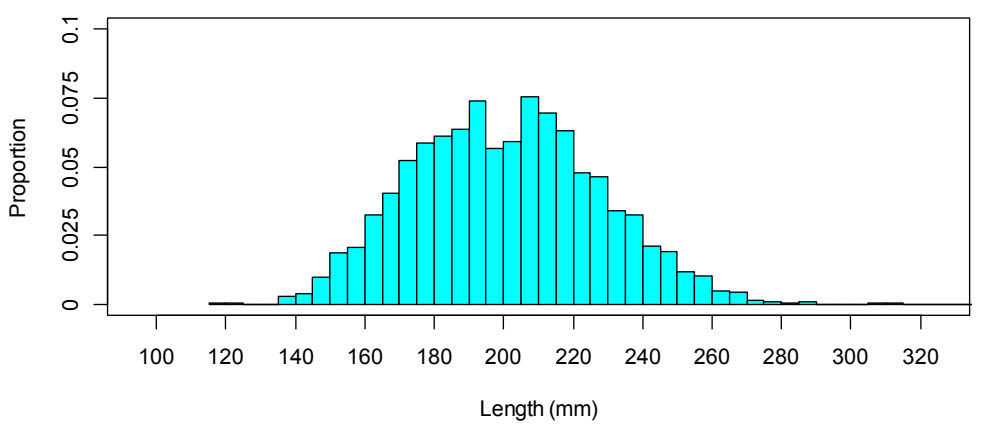

Figure 3.7. Relative frequency distributions for fish lengths $(\mathrm{mm})$ of juvenile steelhead used in a) release $V_{1}$, b) release $R_{2}$, c) release $R_{3}$, and d) ROR fish sampled at John Day Dam by the Fish Passage Center in 2012. 
a. John Day Dam (Release $\left.V_{1}\right)$

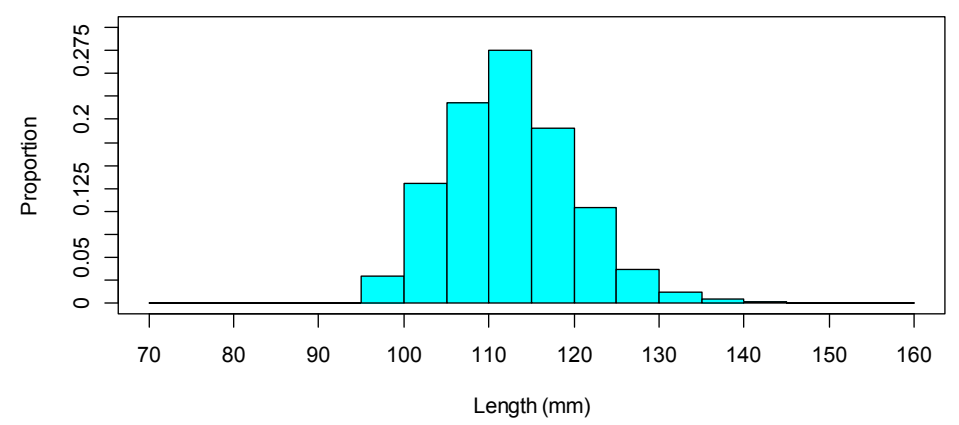

b. John Day Tailrace (Release $R_{2}$ )

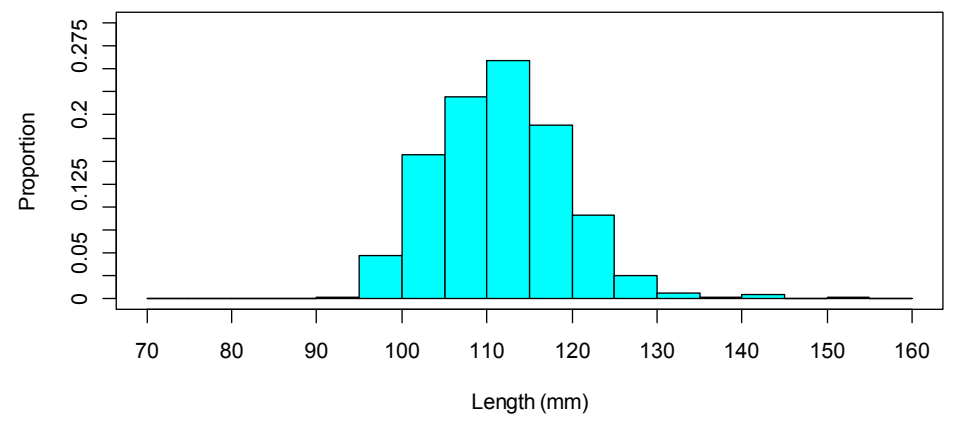

c. John Day Tailwater (Release $R_{3}$ )

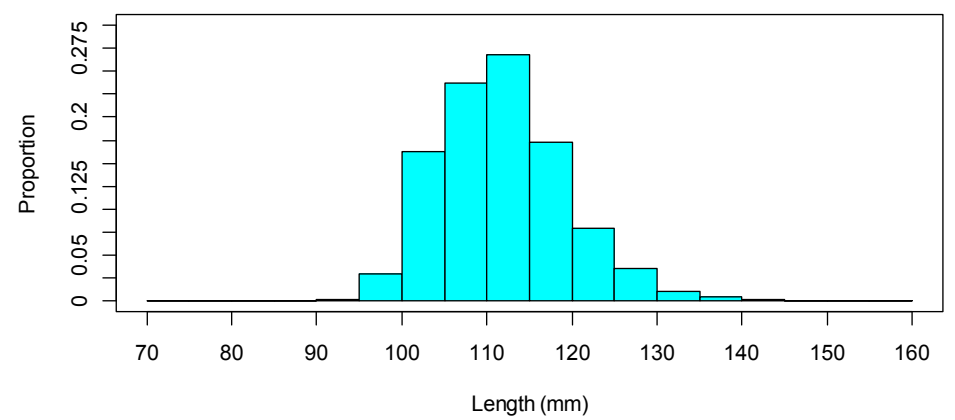

d. ROR Subyearling Chinook Salmon at John Day Dam

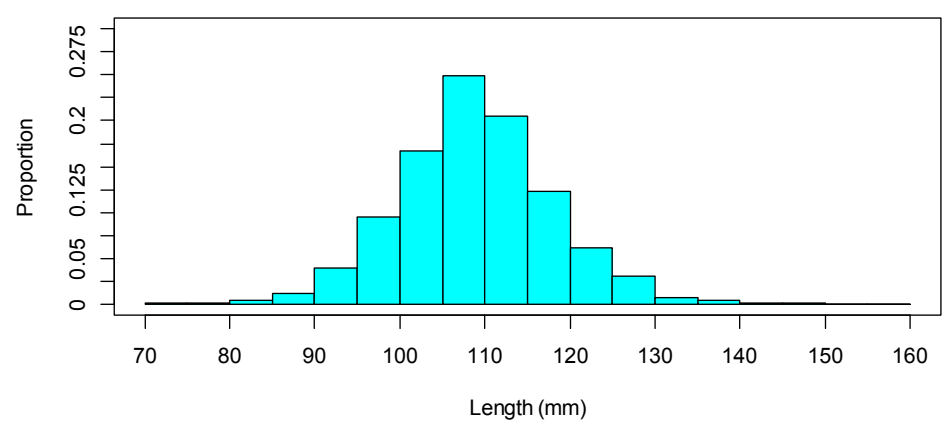

Figure 3.8. Relative frequency distributions for fish lengths $(\mathrm{mm})$ of subyearling Chinook salmon used in a) release $V_{1}, \mathrm{~b}$ ) release $R_{2}, \mathrm{c}$ ) release $R_{3}$, and d) ROR fish sampled at John Day Dam by the Fish Passage Center in 2012 during the period of the study. 
a. Yearling Chinook salmon

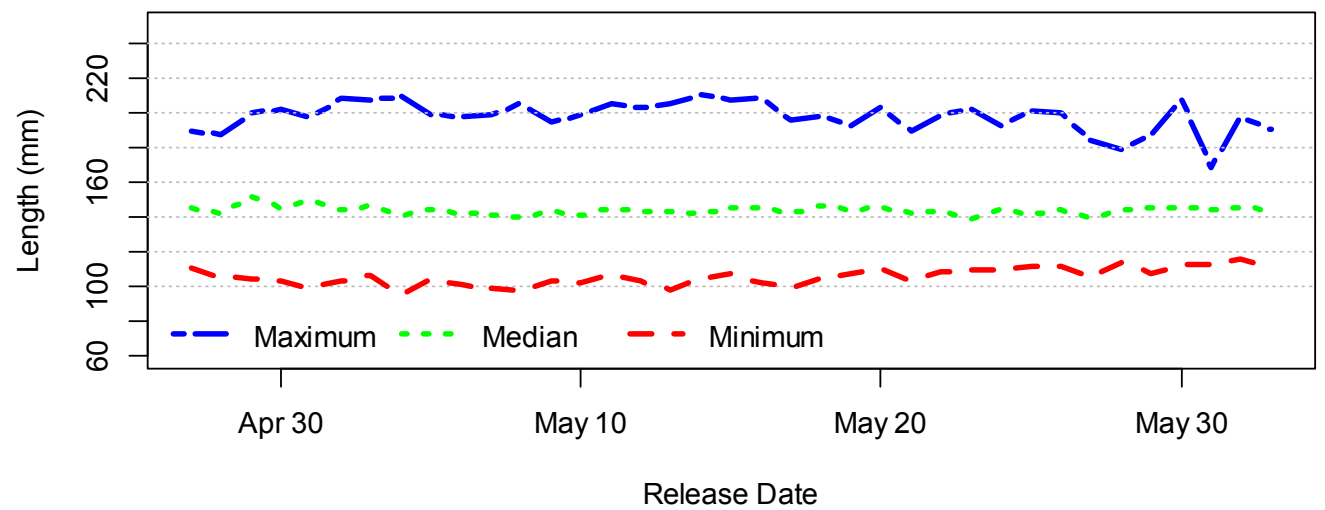

b. Juvenile steelhead

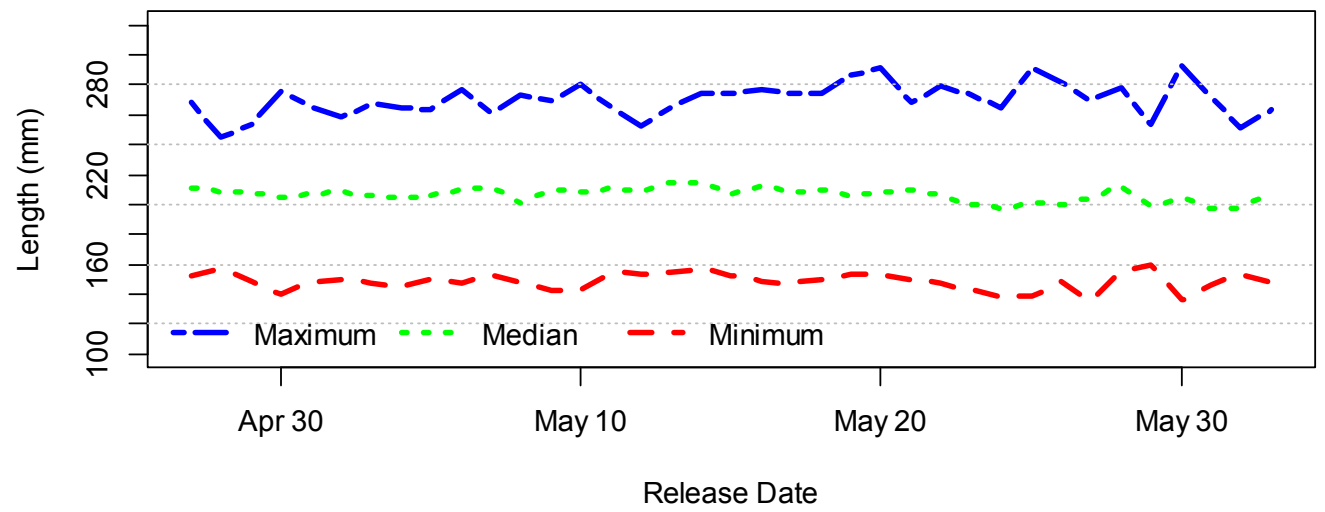

c. Subyearling Chinook salmon

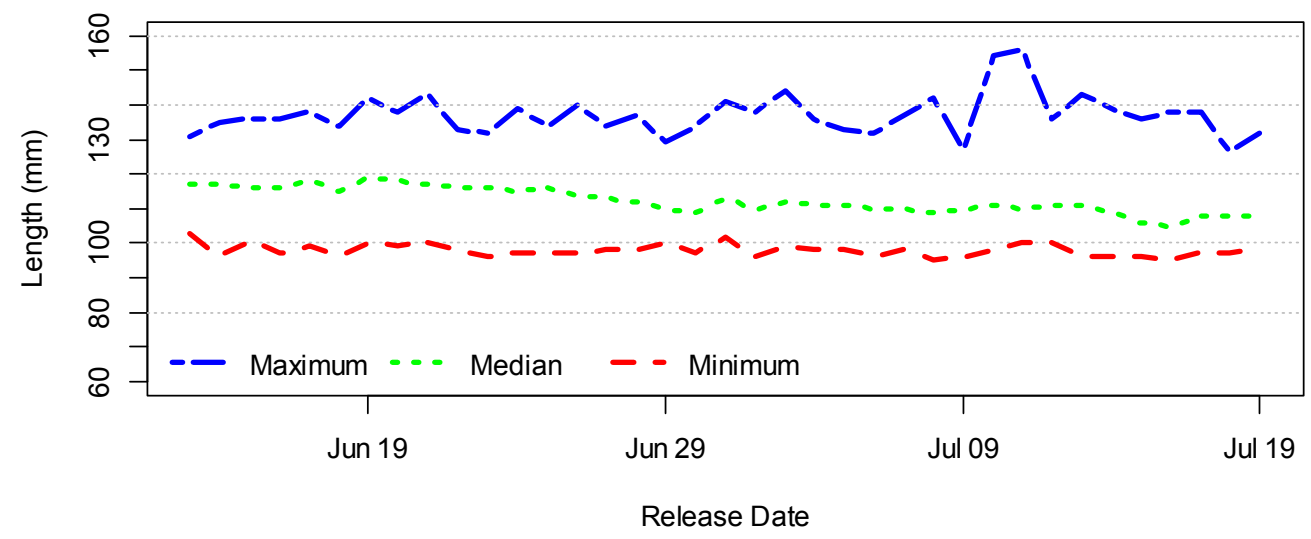

Figure 3.9. Range and median lengths of acoustic-tagged a) yearling Chinook salmon, b) steelhead, and c) subyearling Chinook salmon used over the course of the 2012 survival studies. 
a. Spring - Yearling Chinook Salmon

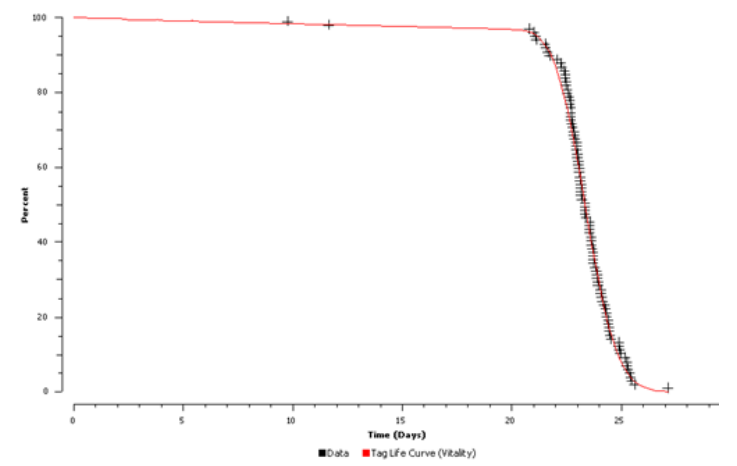

c. Summer - Subyearling Chinook Salmon

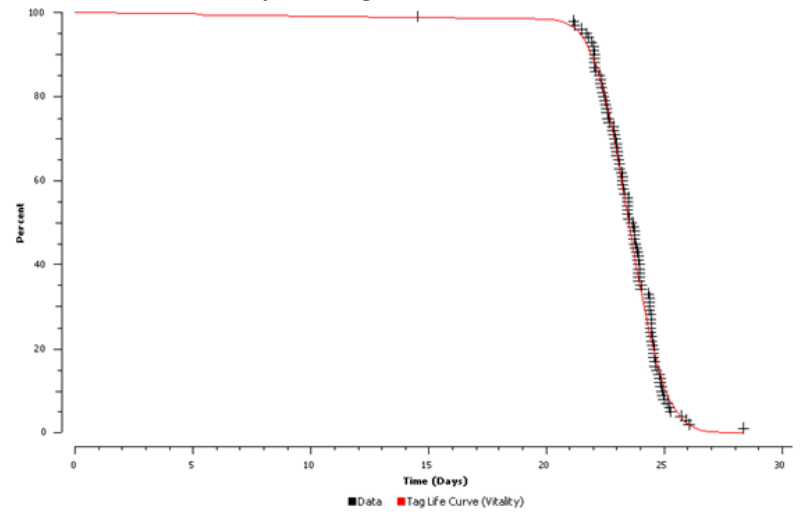

b. Spring - Steelhead

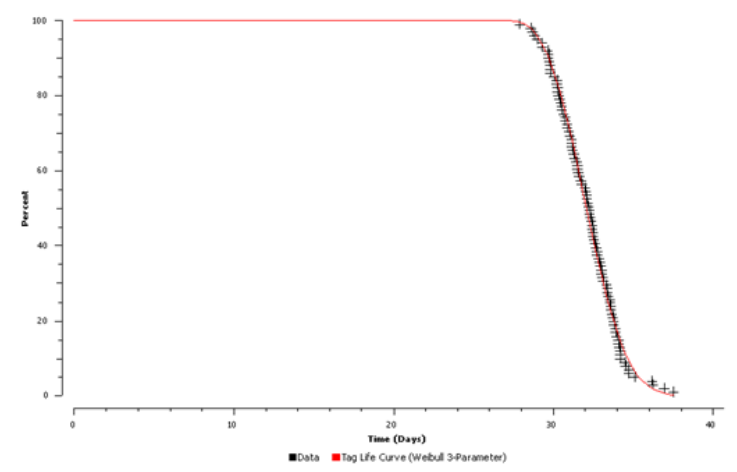

Figure 3.10. Observed time of tag failure and fitted survivorship curves using the vitality model of $\mathrm{Li}$ and Anderson (2009) for a) yearling Chinook salmon and c) subyearling Chinook salmon tag lots and a three-parameter Weibull model for b) steelhead. 
a. Yearling Chinook Salmon

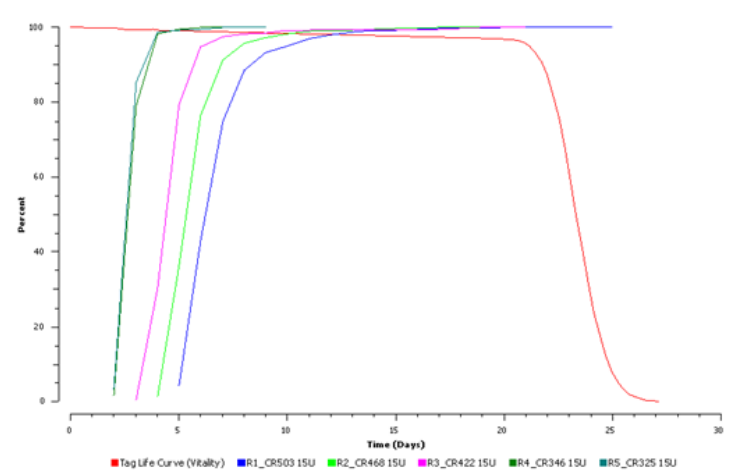

b. Steelhead

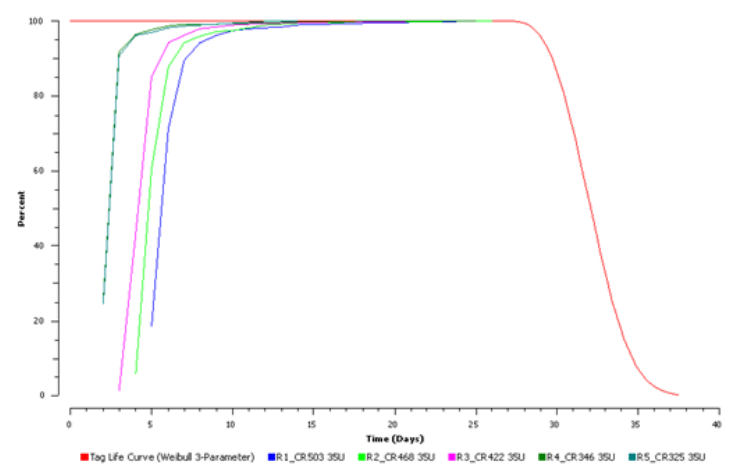

c. Subyearling Chinook Salmon

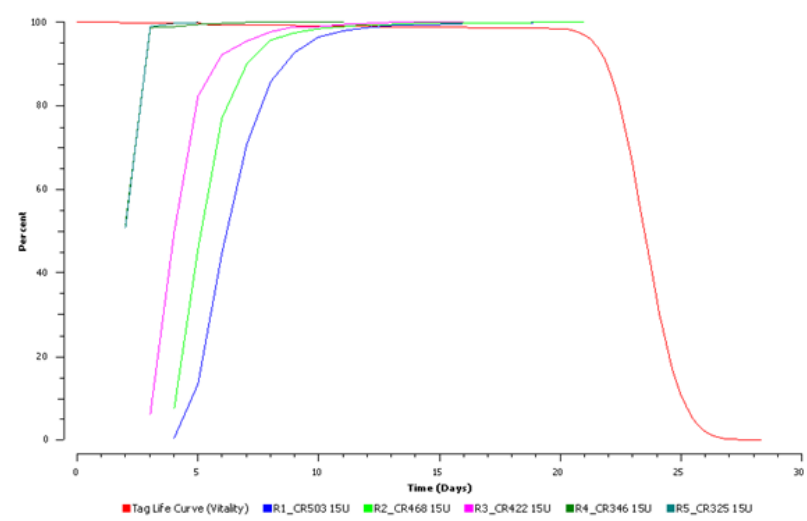

Figure 3.11. Plots of the fitted tag-life survivorship curve and the arrival-time distributions of a) yearling Chinook salmon, b) juvenile steelhead, and c) subyearling Chinook salmon for releases $V_{1}, R_{2}$, and $R_{3}$ at the acoustic-detection array located at rkm 234 (spring) or rkm 275 (summer) (Figure 2.1). 
Table 3.3. Estimated probabilities $(L)$ of an acoustic tag being active at a downstream detection site for a) yearling Chinook salmon, b) juvenile steelhead, and c) subyearling Chinook salmon by release group. (Standard errors are in parentheses.)

\begin{tabular}{|c|c|c|c|c|c|}
\hline \multicolumn{3}{|c|}{ Release Group } & \multicolumn{3}{|c|}{ Detection Site } \\
\hline & Stock & $\mathrm{Rkm}$ & Rkm 325 & Rkm 309 & Rkm 234 \\
\hline \multicolumn{6}{|c|}{ a. Yearling Chinook Salmon } \\
\hline & \multirow[t]{3}{*}{$V_{1}$} & 503 & $0.9994(0.0003)$ & $0.9989(0.0005)$ & $0.9964(0.0012)$ \\
\hline & & 468 & $0.9994(0.0002)$ & $0.9990(0.0004)$ & $0.9974(0.0011)$ \\
\hline & & 422 & $0.9994(0.0003)$ & $0.9989(0.0005)$ & $0.9971(0.0012)$ \\
\hline & $R_{2}$ & 346 & -- & $0.9961(0.0017)$ & $0.9943(0.0024)$ \\
\hline & $R_{3}$ & 325 & -- & $0.9963(0.0016)$ & $0.9944(0.0024)$ \\
\hline \multicolumn{6}{|c|}{ b. Steelhead } \\
\hline & \multirow[t]{3}{*}{$V_{1}$} & 503 & $1.0000(<0.0001)$ & $1.0000(<0.0001)$ & $1.0000(<0.0001)$ \\
\hline & & 468 & $1.0000(<0.0001)$ & $1.0000(<0.0001)$ & $1.0000(<0.0001)$ \\
\hline & & 422 & $1.0000(<0.0001)$ & $1.0000(<0.0001)$ & $1.0000(<0.0001)$ \\
\hline & $R_{2}$ & 346 & -- & $1.0000(<0.0001)$ & $1.0000(<0.0001)$ \\
\hline & $R_{3}$ & 325 & -- & $1.0000(<0.0001)$ & $1.0000(<0.0001)$ \\
\hline c. & \multicolumn{5}{|c|}{ Subyearling Chinook Salmon } \\
\hline & \multirow[t]{3}{*}{$V_{1}$} & 503 & $0.9997(0.0002)$ & $0.9995(0.0005)$ & $0.9992(0.0009)$ \\
\hline & & 468 & $0.9997(0.0002)$ & $0.9995(0.0005)$ & $0.9992(0.0009)$ \\
\hline & & 422 & $0.9997(0.0002)$ & $0.9995(0.0005)$ & $0.9992(0.0009)$ \\
\hline & $R_{2}$ & 346 & -- & $0.9983(0.0019)$ & $0.9979(0.0023)$ \\
\hline & $R_{3}$ & 325 & -- & $0.9983(0.0019)$ & $0.9979(0.0023)$ \\
\hline
\end{tabular}

\subsubsection{Downstream Mixing}

To help induce downstream mixing of the release groups, the $R_{2}$ release was $6 \mathrm{~h}$ before the $R_{3}$ release. The same release schedule was used for both the spring and summer studies. Plots of the arrival timing of the various release groups at downstream detection sites indicate reasonable mixing for yearling Chinook salmon (Figure 3.12), steelhead (Figure 3.13), and subyearling Chinook salmon (Figure 3.14). The arrival modes for releases $R_{2}$ and $R_{3}$ were nearly synchronous in all cases. 
a. $\quad$ rkm 309

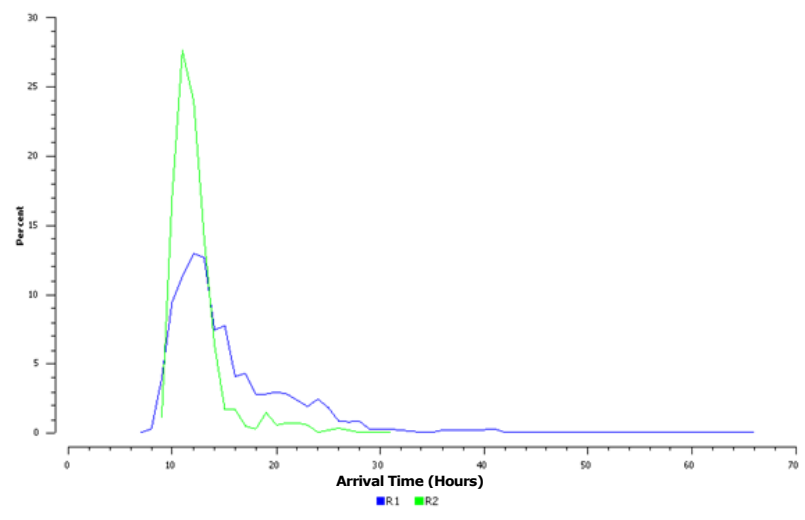

b. $\quad$ rkm 234

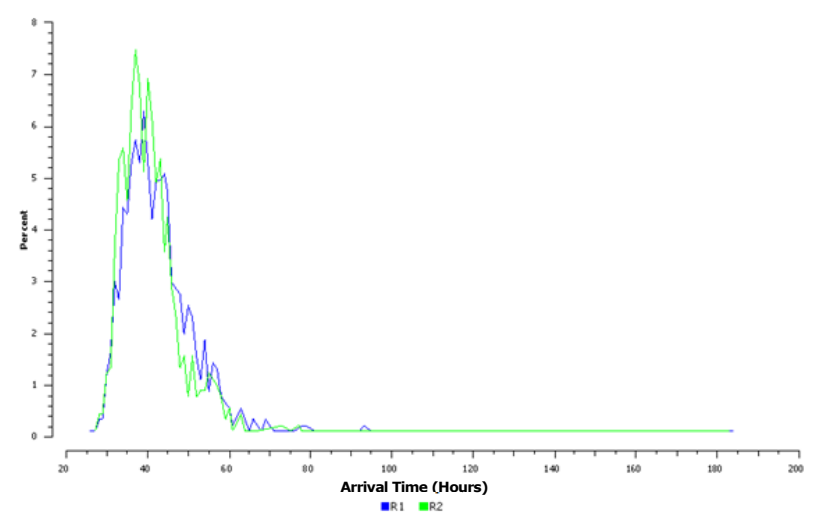

Figure 3.12. Frequency distribution plots of downstream arrival timing (expressed as percentages) for yearling Chinook salmon releases $R_{2}$ and $R_{3}$ at detection arrays located at a) rkm 309 and b) rkm 234 (see Figure 2.1). All times adjusted relative to the release time of $R_{2}$.

a. $\quad$ rkm 309

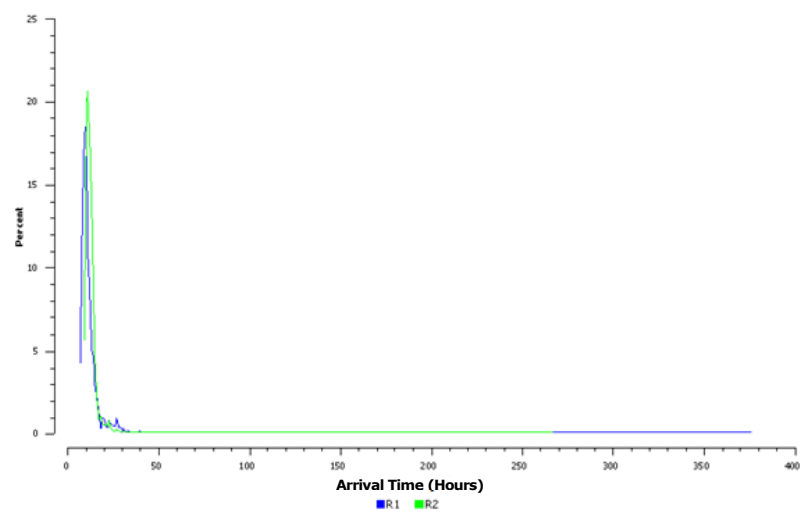

b. $\quad$ rkm 234

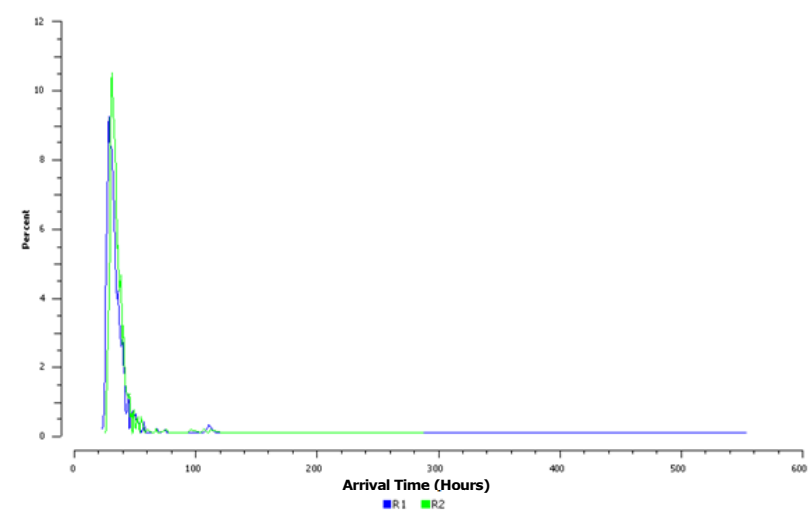

Figure 3.13. Frequency distribution plots of downstream arrival timing (expressed as percentages) for steelhead releases $R_{2}$ and $R_{3}$ at detection arrays located at a) rkm 309 and b) rkm 234 (see Figure 2.1). All times adjusted relative to the release time of $R_{2}$. 
a. $\quad$ rkm 309

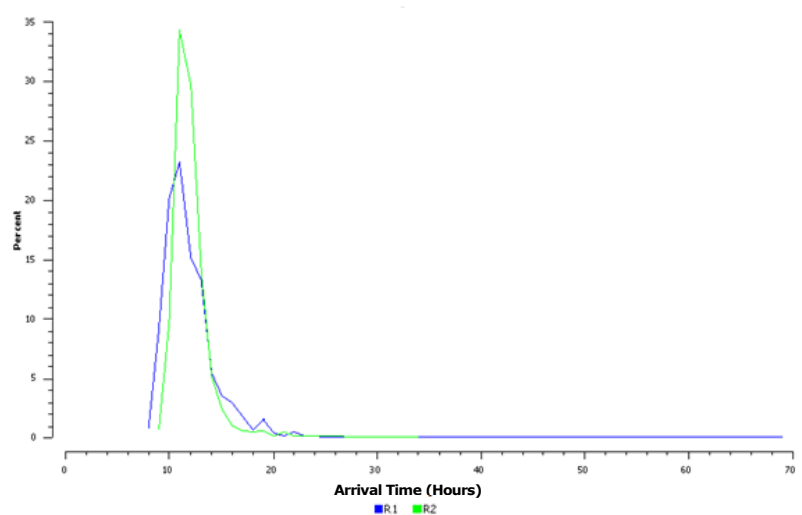

b. $\quad$ rkm 275

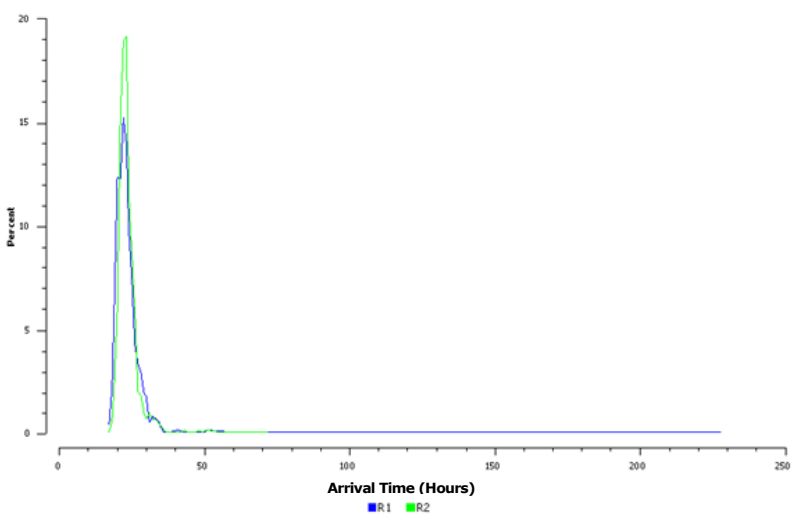

Figure 3.14. Frequency distribution plots of downstream arrival timing (expressed as percentages) for subyearling Chinook salmon releases $R_{2}$ and $R_{3}$ at detection arrays located at a) rkm 309 and b) rkm 275 (see Figure 2.1). All times adjusted relative to the release time of $R_{2}$.

\subsection{Survival and Passage Performance}

Survival and passage performance metrics include dam passage survival, forebay-to-tailrace passage survival, forebay residence time, tailrace to egress time, SPE, and FPE.

\subsubsection{Dam Passage Survival}

The high river flows in 2012 disrupted the planned 30\% and 40\% spill treatments. Season-wide survival estimates were calculated over the prevailing spill conditions.

\subsubsection{Yearling Chinook Salmon}

The estimate of season-wide dam passage survival for yearling Chinook salmon during spring 2012 was calculated to be

$$
\hat{S}_{\text {Dam }}=\frac{0.9627}{\left(\frac{0.9848}{0.9896}\right)}=\frac{0.9627}{0.9951}=0.9673
$$

with an estimated standard error of $\widehat{\mathrm{SE}}=0.0065$ (Table 3.4). This survival estimate exceeds the $2008 \mathrm{BiOp}$ standard of $\geq 0.96$ and with a standard error smaller than required (i.e., $\mathrm{SE} \leq 0.015$ ). Note the single-release survival from the virtual-release group $\left(V_{1}\right)$ to $\mathrm{rkm} 325$ (i.e., including $24 \mathrm{~km}$ of The Dalles reservoir) also exceeds the $2008 \mathrm{BiOp}$ standard (0.9627) with a standard error of $\widehat{\mathrm{SE}}=0.0033$. 
Table 3.4. Survival, detection, and $\lambda$ parameters for final model used to estimate dam passage survival for yearling Chinook salmon during the season-wide spring study (30 April to 2 June 2012). Standard errors (SE) based on both the inverse hessian matrix and bootstrapping for key parameters $(\dagger)$ and only the inverse hessian matrix for associated parameters $(*)$.

\begin{tabular}{|c|c|c|c|c|c|c|}
\hline \multirow[b]{2}{*}{ Release } & \multicolumn{2}{|c|}{ CR349 to 325} & \multicolumn{2}{|c|}{ CR325 to 309} & \multicolumn{2}{|c|}{ Release to CR309 } \\
\hline & $\hat{S}$ & $\widehat{\mathrm{SE}}^{\dagger}$ & $\hat{S}$ & $\widehat{\mathrm{SE}}^{*}$ & $\hat{S}$ & $\widehat{\mathrm{SE}}^{\dagger}$ \\
\hline$V_{1}$ & 0.9627 & 0.0033 & 0.9904 & 0.0018 & --- & -- \\
\hline$R_{2}$ & --- & --- & --- & --- & 0.9848 & 0.0046 \\
\hline \multirow[t]{2}{*}{$R_{3}$} & --- & --- & --- & --- & 0.9896 & 0.0040 \\
\hline & \multicolumn{2}{|c|}{ CR325 } & \multicolumn{2}{|c|}{ CR309 } & & \\
\hline Release & $\hat{p}$ & $\widehat{\mathrm{SE}}^{*}$ & $\hat{p}$ & $\widehat{\mathrm{SE}}^{*}$ & & \\
\hline$V_{1}$ & 0.9997 & 0.0003 & 0.9986 & 0.0007 & & \\
\hline$R_{2}$ & --- & --- & 1.0000 & $<0.0001$ & & \\
\hline \multirow[t]{2}{*}{$R_{3}$} & --- & --- & 1.0000 & $<0.0001$ & & \\
\hline & \multicolumn{2}{|c|}{ CR309-234 } & & & & \\
\hline Release & $\hat{\lambda}$ & $\widehat{\mathrm{SE}}^{*}$ & & & & \\
\hline$V_{1}$ & 0.9218 & 0.0048 & & & & \\
\hline$R_{2}$ & 0.9291 & 0.0083 & & & & \\
\hline$R_{3}$ & 0.9171 & 0.0089 & & & & \\
\hline
\end{tabular}

\subsubsection{Steelhead}

The estimate of season-wide dam passage survival for steelhead in spring 2012 was calculated to be

$$
\hat{S}_{\text {Dam }}=\frac{0.9744}{\left(\frac{0.9781}{0.9752}\right)}=\frac{0.9744}{1.0030} \stackrel{\text { set }}{=} 0.9744
$$

Because the paired release of $R_{2}$ and $R_{3}$ estimated survival between the John Day tailrace (rkm 346) and rkm 325 was $>1$, the recommended survival estimate for John Day Dam is the conservative estimate for single-release survival through the dam based on the virtual-release group where $\hat{S}_{\text {Dam }} \geq \hat{S}_{1}=0.9744$ with a standard error of $\widehat{\mathrm{SE}}=0.0028$ (Table 3.5). 
Table 3.5. Survival, detection, and $\lambda$ parameters for final model used to estimate dam passage survival for steelhead during the season-wide spring study (30 April to 2 June 2012). Standard errors (SE) based on both the inverse hessian matrix and bootstrapping for key parameters $(\dagger)$ and only the inverse hessian matrix for associated parameters $(*)$.

\begin{tabular}{|c|c|c|c|c|c|c|}
\hline \multirow[b]{2}{*}{ Release } & \multicolumn{2}{|c|}{ CR349 to 325} & \multicolumn{2}{|c|}{ CR325 to 309} & \multicolumn{2}{|c|}{ Release to CR309 } \\
\hline & $\hat{S}$ & $\widehat{\mathrm{SE}}^{\dagger}$ & $\hat{S}$ & $\widehat{\mathrm{SE}}^{*}$ & $\hat{S}$ & $\widehat{\mathrm{SE}}^{\dagger}$ \\
\hline$V_{1}$ & 0.9744 & 0.0028 & 0.9954 & 0.0012 & -- & -- \\
\hline$R_{2}$ & --- & --- & --- & --- & 0.9781 & 0.0046 \\
\hline \multirow[t]{2}{*}{$R_{3}$} & --- & --- & --- & --- & 0.9752 & 0.0049 \\
\hline & \multicolumn{2}{|c|}{ CR325 } & \multicolumn{2}{|c|}{ CR309 } & & \\
\hline Release & $\hat{p}$ & $\widehat{\mathrm{SE}}^{*}$ & $\hat{p}$ & $\widehat{\mathrm{SE}}^{*}$ & & \\
\hline$V_{1}$ & 0.9997 & 0.0003 & 0.9983 & 0.0008 & & \\
\hline$R_{2}$ & --- & --- & 0.9989 & 0.0011 & & \\
\hline \multirow[t]{2}{*}{$R_{3}$} & --- & --- & 0.9978 & 0.0016 & & \\
\hline & \multicolumn{2}{|c|}{ CR309-234 } & & & & \\
\hline Release & $\hat{\lambda}$ & $\widehat{\mathrm{SE}}^{*}$ & & & & \\
\hline$V_{1}$ & 0.9349 & 0.0044 & & & & \\
\hline$R_{2}$ & 0.9498 & 0.0070 & & & & \\
\hline$R_{3}$ & 0.9270 & 0.0083 & & & & \\
\hline
\end{tabular}

\subsubsection{Subyearling Chinook Salmon}

The estimate of season-wide dam passage survival for subyearling Chinook salmon during summer 2012 was calculated to be

$$
\hat{S}_{\text {Dam }}=\frac{0.9414}{\left(\frac{0.9966}{0.9925}\right)}=\frac{0.9414}{1.0041} \stackrel{\text { set }}{=} 0.9414
$$

Because the paired release of $R_{2}$ and $R_{3}$ estimated survival between the John Day tailrace (rkm 346) and rkm 325 was $>1$, the recommended survival estimate for John Day Dam is the conservative estimate for single-release survival through the dam based on the virtual-release group where $\hat{S}_{\text {Dam }}>\hat{S}_{1}=0.9414$ with a standard error of $\widehat{\mathrm{SE}}=0.0031$ (Table 3.6).

In all three cases of yearling Chinook salmon, steelhead, and subyearling Chinook salmon, the $R_{2}-R_{3}$ paired-release estimates of survival between the tailrace and rkm 325 were very similar, with values of $0.9951,1.0030$, and 1.0031, respectively. The average of these values is 1.0007 .

In all of the above analyses, the full model that estimated unique survival and capture probabilities for each release group was used in the calculation of dam passage survival. Precision was more than adequate (i.e., $\widehat{\mathrm{SE}} \leq 0.015$ ), so there was no need to attempt to find a more parsimonious model to improve precision. In this way, both precision and robustness were preserved. 
Table 3.6. Survival, detection, and $\lambda$ parameters for final model used to estimate dam passage survival for subyearling Chinook during the season-wide spring study (17 June to 19 July 2012). Standard errors (SE) based on both the inverse hessian matrix and bootstrapping for key parameters $(\dagger)$ and only the inverse hessian matrix for associated parameters $(*)$.

\begin{tabular}{|c|c|c|c|c|c|c|}
\hline \multirow[b]{2}{*}{ Release } & \multicolumn{2}{|c|}{ CR349 to 325} & \multicolumn{2}{|c|}{ CR325 to 309} & \multicolumn{2}{|c|}{ Release to CR309 } \\
\hline & $\hat{S}$ & $\widehat{\mathrm{SE}}^{\dagger}$ & $\hat{S}$ & $\widehat{\mathrm{SE}}^{*}$ & $\hat{S}$ & $\widehat{\mathrm{SE}}^{\dagger}$ \\
\hline$\overline{V_{1}}$ & 0.9414 & 0.00313 & 0.9906 & 0.0013 & --- & --- \\
\hline$R_{2}$ & --- & --- & --- & --- & 0.9966 & 0.0033 \\
\hline \multirow[t]{2}{*}{$R_{3}$} & --- & --- & --- & --- & 0.9925 & 0.0039 \\
\hline & \multicolumn{2}{|c|}{ CR325 } & \multicolumn{2}{|c|}{ CR309 } & & \\
\hline Release & $\hat{p}$ & $\widehat{\mathrm{SE}}^{*}$ & $\hat{p}$ & $\widehat{\mathrm{SE}}^{*}$ & & \\
\hline$\overline{V_{1}}$ & 0.9996 & 0.0003 & 0.9992 & 0.0004 & & \\
\hline$R_{2}$ & --- & --- & 1.0000 & $<0.0001$ & & \\
\hline \multirow[t]{2}{*}{$R_{3}$} & --- & --- & 1.0000 & $<0.0001$ & & \\
\hline & \multicolumn{2}{|c|}{ CR309-275 } & & & & \\
\hline Release & $\hat{\lambda}$ & $\widehat{\mathrm{SE}}^{*}$ & & & & \\
\hline$V_{1}$ & 0.9418 & 0.0032 & & & & \\
\hline$R_{2}$ & 0.9371 & 0.0078 & & & & \\
\hline$R_{3}$ & 0.9480 & 0.0071 & & & & \\
\hline
\end{tabular}

\subsubsection{Forebay-to-Tailrace Passage Survival}

The estimates of forebay-to-tailrace passage survival were calculated analogously to that of dam passage survival except the virtual-release group $\left(V_{1}\right)$ was composed of fish known to have arrived at the forebay (i.e., detection array rkm 351, Figure 2.1) rather than at the dam face. These season-wide survival estimates were based on all release data across the season, regardless of spill conditions. Using the same statistical model as was used in estimating dam passage survival, forebay-to-tailrace survival for yearling Chinook salmon was

$$
\hat{S}_{\text {forebay-to-tailrace }}=0.9660(0.0065)
$$

for steelhead,

$$
\hat{S}_{\text {forebay-to-tailrace }}=0.9687(0.0030)^{1}
$$

and for subyearling Chinook salmon,

$$
\hat{S}_{\text {forebay-to-tailrace }}=0.9390(0.0032)^{1}
$$

\footnotetext{
${ }^{1}$ Based on the single release from $V_{1}$ only.
} 


\subsubsection{Forebay Residence Time}

The forebay residence time was calculated from the first detection at the forebay BRZ array to the last detection at the dam $(2 \mathrm{rkm})$. For yearling Chinook salmon, the mean forebay residence time was estimated to be $2.50 \mathrm{~h}$ ( $\widehat{\mathrm{SE}}=0.14)$, for steelhead it was estimated to be $5.79 \mathrm{~h}$ ( $\widehat{\mathrm{SE}}=0.33)$, and for subyearling Chinook salmon it was estimated to be $2.91 \mathrm{~h}(\widehat{\mathrm{SE}}=0.26)$ (Figure 3.15, Table 3.7). The distribution of forebay residence times indicates the modes were $1.0 \mathrm{~h}$ for yearling Chinook salmon, $1.5 \mathrm{~h}$ for steelhead, and $1.0 \mathrm{~h}$ for subyearling Chinook salmon. Median residence times were $1.15 \mathrm{~h}, 2.39 \mathrm{~h}$, and $1.02 \mathrm{~h}$ for yearling Chinook salmon, steelhead, and subyearling Chinook salmon, respectively (Table 3.7).

\subsubsection{Tailrace Egress Time}

The tailrace egress time was calculated based on the time from the last detection of fish at the double array at the face of John Day Dam to the last detection at the BRZ tailrace array (Figure 3.16). Mean tailrace egress time for yearling Chinook salmon was estimated to be $\bar{t}=2.80 \mathrm{~h}$ ( $\widehat{\mathrm{SE}}=0.28)$. For juvenile steelhead, mean tailrace egress time was estimated to be $\bar{t}=6.22 \mathrm{~h}(\widehat{\mathrm{SE}}=0.48)$. Mean tailrace egress time for subyearling Chinook salmon was estimated to be $\bar{t}=2.95 \mathrm{~h}(\widehat{\mathrm{SE}}=0.16$ ). Median egress times were $0.50,0.46$, and $0.48 \mathrm{~h}$ for yearling Chinook salmon, steelhead, and subyearling Chinook salmon, respectively (Table 3.7). The distribution of tailrace egress times indicates the modes were $0.5 \mathrm{~h}$ for yearling Chinook salmon, steelhead, and subyearling Chinook salmon (Figure 3.16).

\subsubsection{Spill Passage Efficiency}

Spill passage efficiency is defined as the fraction of the fish that passed through a hydroproject by the spillway, including the temporary spill weirs. The double-detection array at the face of John Day Dam was used to identify and track fish as they entered the forebay. Given that the combined detection efficiency of double array was $100 \%$ for each run of fish passing each route, we were able to use observed counts of fish entering the various routes at John Day Dam to estimate SPE based on a binomial sampling model. For yearling Chinook salmon, $\mathrm{SPE}=0.7456$ (0.0075); for juvenile steelhead, $\mathrm{SPE}=0.7452$ (0.0076); and for subyearling Chinook salmon, $\mathrm{SPE}=0.6962$ (0.0061).

\subsubsection{Fish Passage Efficiency}

Fish passage efficiency, called SPE in the Fish Accords, is the fraction of the fish that passed through non-turbine routes at the dam. As with SPE, the double-detection array at the face of John Day Dam was used to identify and track fish as they entered the dam. Given $100 \%$ combined detection efficiency by the double array for each route and run of fish, we were able to use observed counts of fish entering the various routes at John Day Dam were used to estimate FPE based on a binomial sampling model. For yearling Chinook salmon at John Day Dam in 2012, FPE is estimated to be FPE $=0.9272$ (0.0045); for juvenile steelhead, FPE $=0.9695$ (0.0030); and for subyearling Chinook salmon, FPE $=0.8585$ (0.0046). 
a. Yearling Chinook salmon

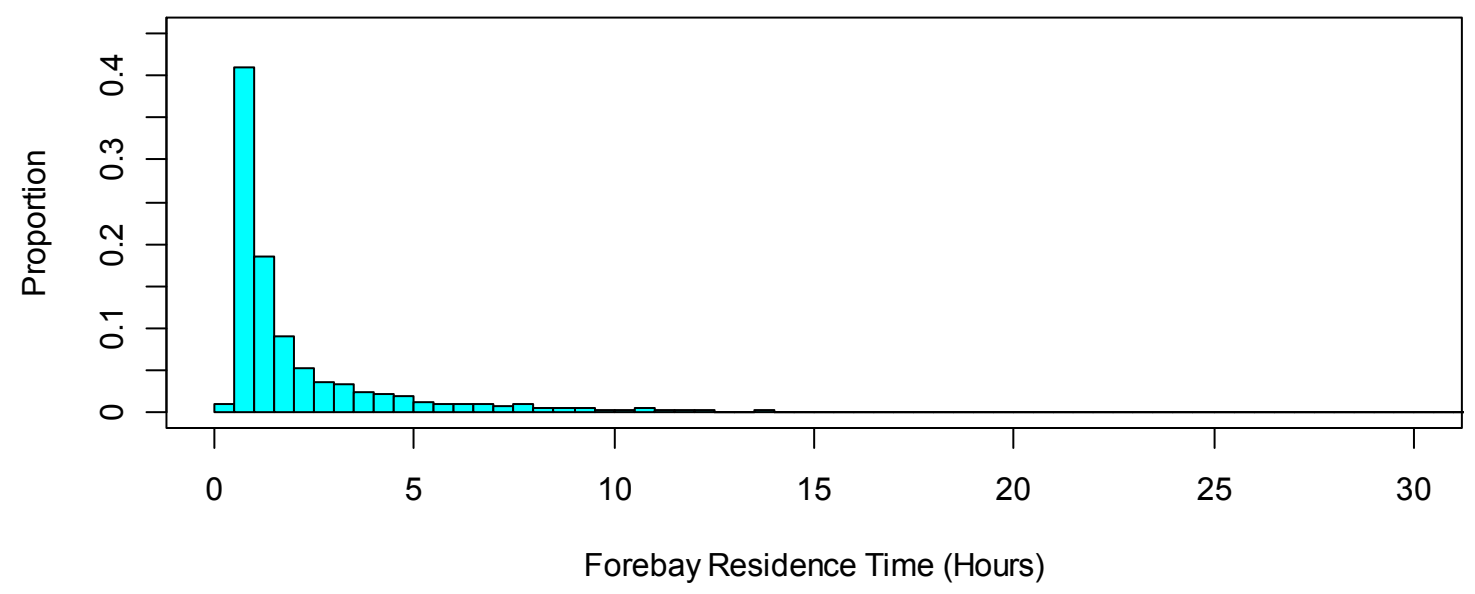

b. Steelhead

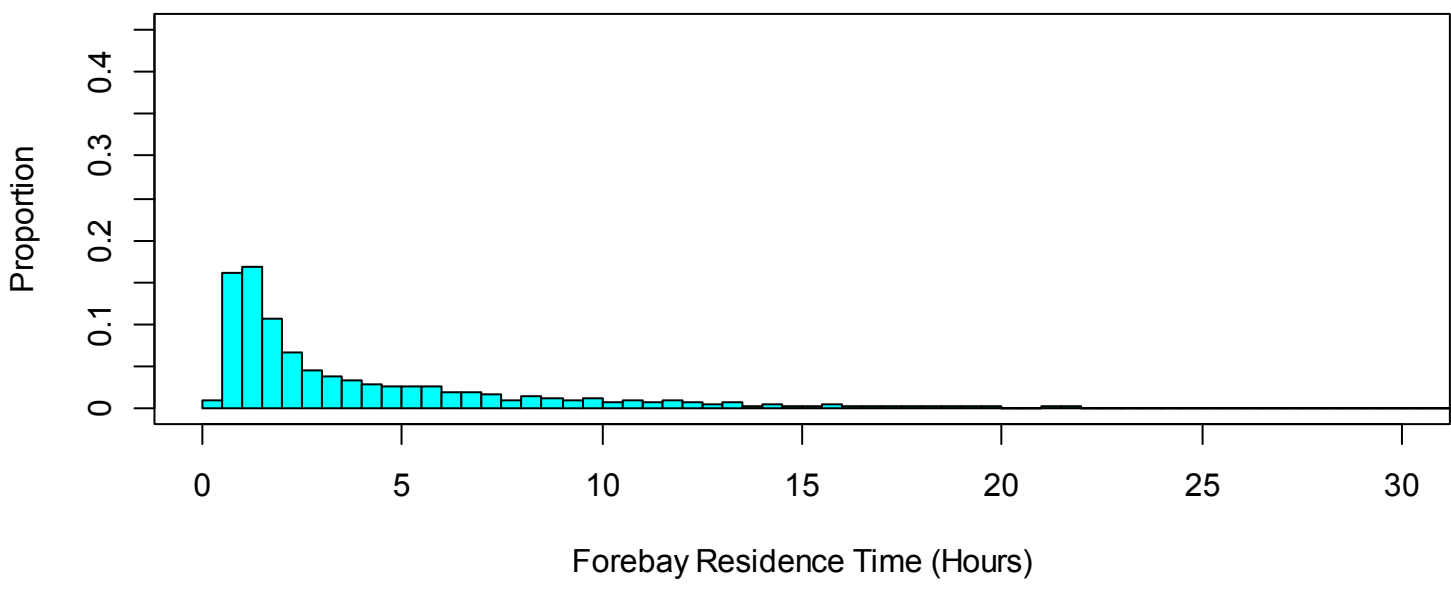

c. Subyearling Chinook salmon

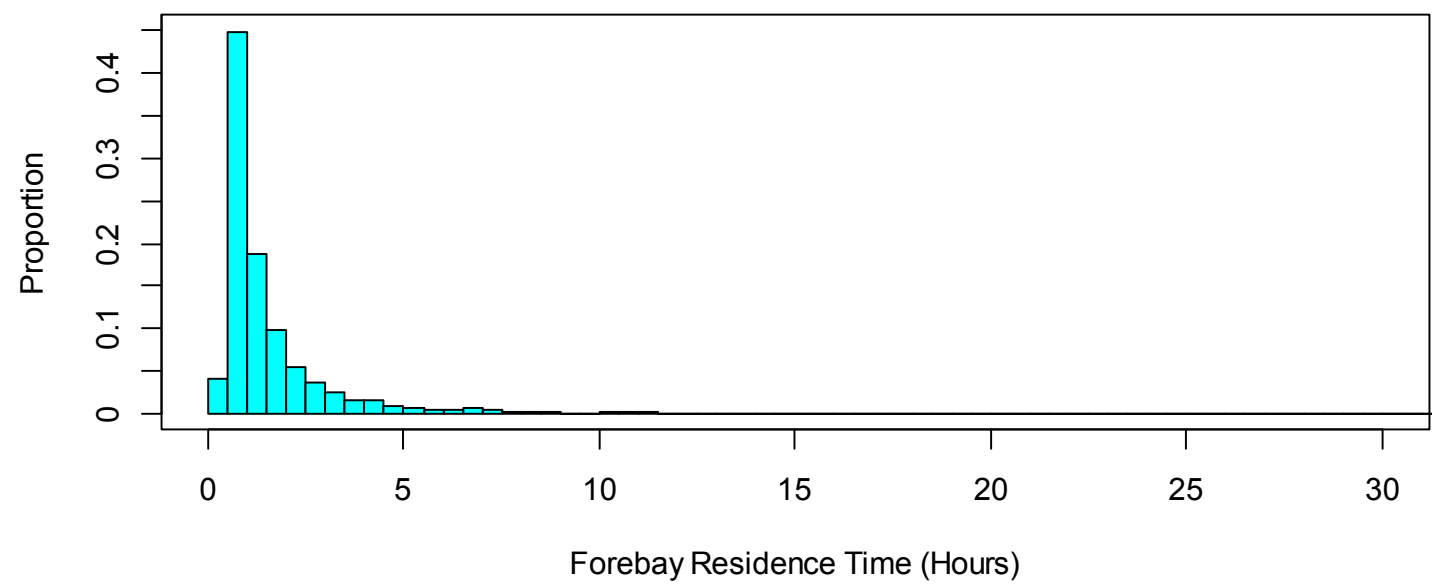

Figure 3.15. Distribution of forebay residence times for a) yearling Chinook salmon, b) steelhead, and c) subyearling Chinook salmon at John Day Dam, 2012. 
Table 3.7. Estimated mean and median forebay residence times (h) and mean and median tailrace egress times for yearling Chinook salmon, steelhead, and subyearling Chinook salmon at John Day Dam in 2012. (Standard errors in parentheses.)

\begin{tabular}{llll}
\hline Performance Measure & Yearling Chinook Salmon & Steelhead & Subyearling Chinook Salmon \\
\hline Forebay Residence Time & & & \\
- Mean & $2.50(0.14)$ & $5.79(0.33)$ & $2.91(0.26)$ \\
- Median & 1.15 & 2.39 & 1.02 \\
Tailrace Egress Time & & & $2.95(0.16)$ \\
- Mean & $2.80(0.28)$ & $6.22(0.48)$ & 0.48 \\
- Median & 0.50 & 0.46 & \\
- & & & \\
\hline
\end{tabular}


a. Yearling Chinook salmon

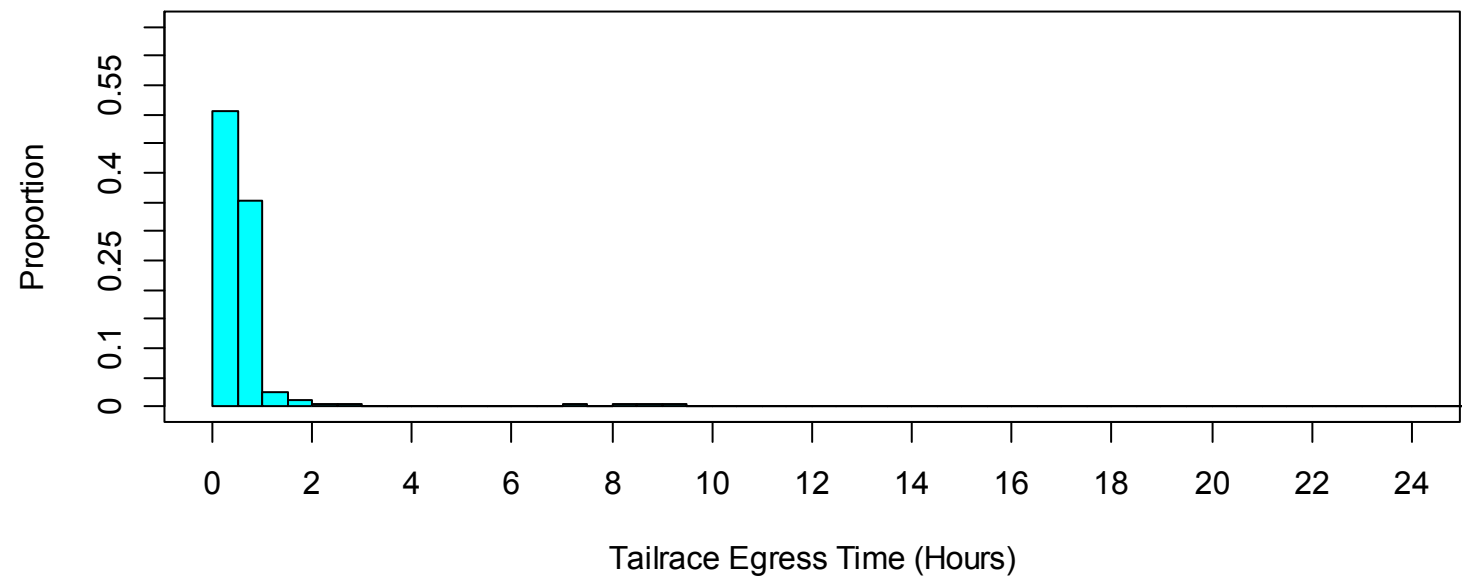

b. Steelhead

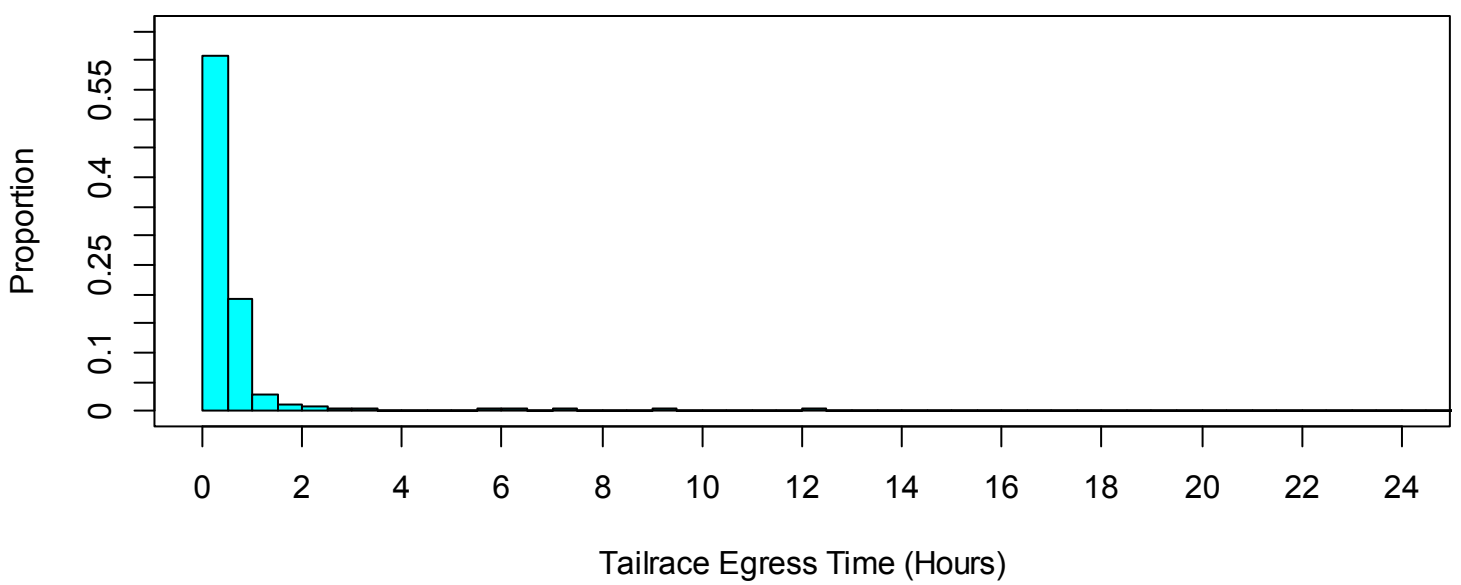

c. Subyearling Chinook salmon

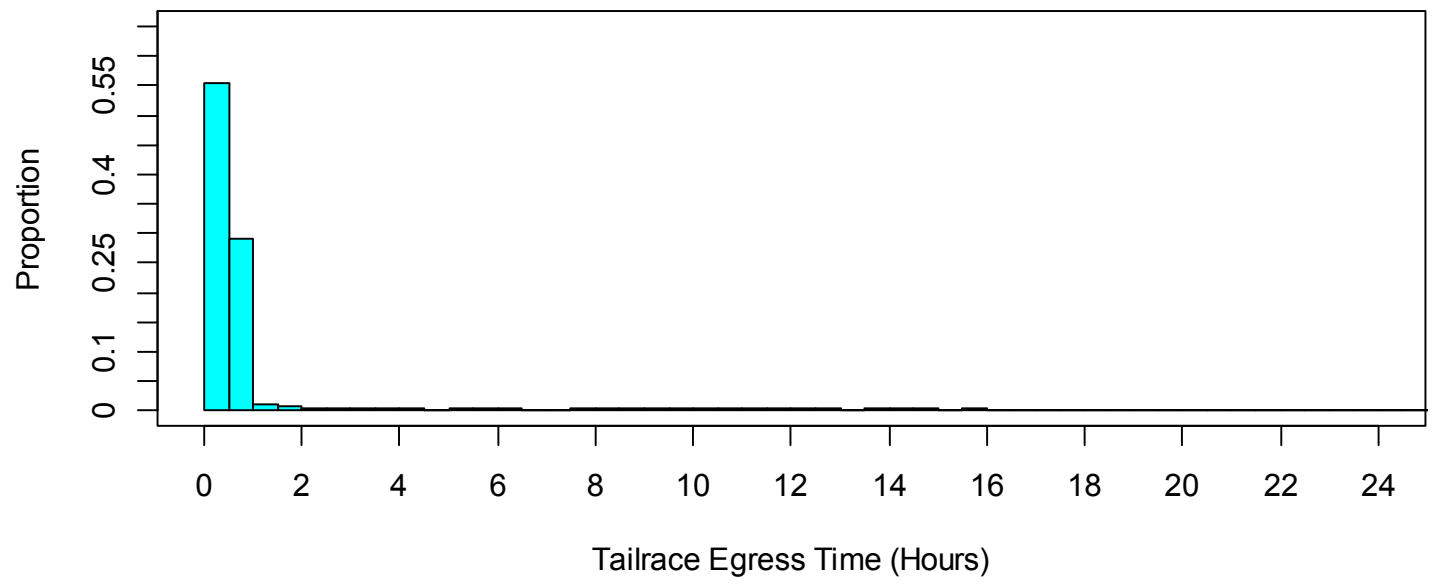

Figure 3.16. Distribution of tailrace egress times for a) yearling Chinook salmon, b) steelhead, and c) subyearling Chinook salmon at John Day Dam, 2012. 


\subsection{Discussion}

The discussion describes the conduct of the 2012 study, study performance, and compares the 2012 estimates with compliance results in 2011 at John Day Dam.

\subsection{Study Conduct}

The many tests of assumptions (Appendix A) found the acoustic-tag study achieved good downstream mixing, with adequate tag life and no evidence of adverse tagger effects. There was no evidence that delayed tagging/handling effects were present that might affect the performance of the $V_{1}$ release at the face of the dam. These results suggest the assumptions of the virtual/paired-release model were fulfilled, permitting valid estimation of dam passage survival and related parameters.

Despite not being able to compare compliance under $30 \%$ and $40 \%$ spill conditions, the season-wide estimates of dam passage survival in 2012 for yearling and subyearling Chinook salmon and steelhead met the $2008 \mathrm{BiOp}$ standards for point estimates and adequate precision.

\subsection{Study Performance}

The 2012 spring and summer compliance studies at John Day Dam were interrupted by high flow conditions that precluded conducting the $30 \%$ and $40 \%$ spill blocks. Early parts of the season were slightly above $40 \%$, while the remainder of the spring and summer studies fluctuated between $30-40 \%$ (Figure 3.1). No attempt was made to tease out days near the $30 \%$ and $40 \%$ spill targets. Instead, a single season-wide estimate of dam passage survival was calculated for each fish stock.

Results of the compliance studies suggest that BiOp survival standards at John Day Dam can be met under prevailing conditions with spills in the range of 30-40\%. Ultimate acceptance of the 2012 study results at John Day Dam will depend on whether the fisheries community considers the 2012 flow and spill conditions to be nominal.

\subsection{Summary of Compliance Study Results}

The compliance studies in 2012 were the second year of investigations at John Day Dam. During 2011, the first year of investigations, compliance studies were conducted in spring on yearling Chinook salmon and steelhead. To date, five compliance studies have been performed at John Day Dam (Table 4.1). There have now been two compliance studies of yearling Chinook salmon and steelhead and one study of subyearling Chinook salmon. All five studies met the $2008 \mathrm{BiOp}$ standards for dam passage survival and associated standard errors. 
Table 4.1. Summary of estimates of dam passage survival at John Day Dam from the 2011 and 2012 JSATS compliance studies. (Standard errors in parentheses.)

\begin{tabular}{lcc}
\hline \multicolumn{1}{c}{ Fish Stock } & \multicolumn{2}{c}{ Year of Study } \\
\cline { 2 - 3 } & 2011 & 2012 \\
\hline Yearling Chinook Salmon & $0.9678(0.0071)$ & $0.9673(0.0065)$ \\
Steelhead & $0.9867(0.0061)$ & $0.9744(0.0028)$ \\
Subyearling Chinook Salmon & & $0.9414(0.0031)$ \\
\hline
\end{tabular}




\subsection{References}

3 Treaty Tribes-Action Agencies. 2008. Memorandum of Agreement Among the Umatilla, Warm Springs and Yakama Tribes, Bonneville Power Administration, U.S. Army Corps of Engineers, and U.S. Bureau of Reclamation, Portland, Oregon, April 4, 2008. Available at http://www.salmonrecovery.gov/Files/BiologicalOpinions/3-tribe-AA-MOA-Final.pdf.

Burnham KP, DR Anderson, GC White, C Brownie, and KH Pollock. 1987. "Design and analysis methods for fish survival experiments based on release-recapture." American Fisheries Society Monograph 5.

CBSPSC (Columbia Basin Surgical Protocol Steering Committee). 2011. Surgical Protocols for Implanting JSATS Transmitters into Juvenile Salmonids for Studies Conducted for the U.S. Army Corps of Engineers. V1, 21 pp. U.S. Army Corps of Engineers, Portland District, Portland, Oregon.

Elandt-Johnson RC, and NL Johnson. 1980. Survival Models and Data Analysis. Wiley, New York.

Li T and JJ Anderson. 2009. "The vitality model: A way to understand population survival and demographic heterogeneity." Theoretical Population Biology 76:118-131.

Martinson R, G Kovalchuk, and D Ballinger. 2006. Monitoring of Downstream Salmon and Steelhead at Federal Hydroelectric Facilities. 2005-2006 Annual Report, Project No. 198712700, BPA Report DOE/BP-00022085-2, Portland, Oregon.

NMFS (National Marine Fisheries Service). 2008. Biological Opinion-Consultation on Remand for Operation of the Federal Columbia River Power System, 11 Bureau of Reclamation Projects in the Columbia Basin and ESA Section 10(a)(1)(A) Permit for Juvenile Fish Transportation Program. National Marine Fisheries Service (NOAA Fisheries) - Northwest Region, Seattle, Washington. Available at: http://www.salmonrecovery.gov/.

Seber GAF. 1982. The Estimation of Animal Abundance. MacMillan, New York.

Skalski JR, GE Johnson, and TJ Carlson. 2010a. Compliance Monitoring of Juvenile Yearling Chinook Salmon and Steelhead Survival and Passage at The Dalles Dam, Spring 2010. PNNL-19819, summary report submitted to the U.S. Army Corps of Engineers, Portland District, Portland, Oregon, by Pacific Northwest National Laboratory, Richland, Washington.

Skalski JR, RL Townsend, TW Steig, and S Hemstrom. 2010b. "Comparison of two alternative approaches for estimating dam passage survival using acoustic-tagged sockeye salmon smolts." North American Journal of Fisheries Management 30:831-839.

Townsend RL, JR Skalski, P Dillingham, and TW Steig. 2006. "Correcting bias in survival estimation resulting from tag failure in acoustic and radiotelemetry studies." Journal of Agricultural Biology and Environmental Statistics 11(2):183-196. 
Weiland MA, GR Ploskey, JS Hughes, and fifteen co-authors. 2009. Acoustic Telemetry Evaluation of Juvenile Salmonid Passage and Survival at John Day Dam with Emphasis on the Prototype Surface Flow Outlet, 2008. PNNL-18890, final report submitted to the U.S. Army Corps of Engineers, Portland District, Portland, Oregon, by Pacific Northwest National Laboratory, Richland, Washington.

Weiland MA, GR Ploskey, JS Hughes, and sixteen coauthors. 2011. Acoustic Telemetry Evaluation of Juvenile Salmonid Passage and Survival Proportions at John Day Dam, 2009. PNNL-20766, final report submitted to the U.S. Army Corps of Engineers, Portland District, Portland, Oregon, by Pacific Northwest National Laboratory, Richland, Washington.

Weiland MA, GR Ploskey, CM Woodley, and twenty-three coauthors. 2013. Acoustic Telemetry Evaluation of Juvenile Salmonid Passage and Survival at John Day Dam, 2010. Draft Technical Report submitted to the U.S. Army Corps of Engineers, Portland District, Portland, Oregon, by Pacific Northwest National Laboratory, Richland, Washington. 
Appendix A

Tests of Assumptions 


\section{Appendix A}

\section{Test of Assumptions}

\section{A.1 Tagger Effects}

\section{A.1.1 Spring Study}

Data from all five release locations in the two-dam study were examined for tagger effects. This was done to maximize the statistical power to detect tagger effects that might have influenced either or both of the McNary and John Day dam studies.

To minimize any tagger effects that might go undetected, tagger effort should be balanced across release locations and within replicates. A total of eight taggers participated in tagging the yearling Chinook salmon and steelhead during the spring study. Tagger effort was found to be balanced across the five release locations regardless of whether the data were pooled across species $\left(P\left(\chi_{28}^{2} \geq 7.8016\right)=0.9999\right)$, or analyzed separately for yearling Chinook salmon $\left(P\left(\chi_{28}^{2} \geq 4.3024\right) \approx 1\right)$ or steelhead $\left(P\left(\chi_{28}^{2} \geq 5.1934\right) \approx 1\right)$ (Table A.1).

Tagger effort was examined within each of the 32 replicate releases conducted over the course of the spring study (Table A.2, Table A.3). Tagger effort was found to be balanced within replicates 1, 5, 9, 13, $17,21,25$, and $29(P \approx 1)$. To accommodate staff time off during the month-long study, tagger effort was conditionally balanced within the individual project releases (i.e., $R_{1}-R_{3}, R_{4}-R_{5}$ ) (Table A.2, Table A.3) for the remainder of the replicate release groups. This conditional and unconditional balance within replicates is the reason for the overall balance observed in Table A.1.

To test for tagger effects, reach survivals and cumulative survivals were calculated for fish tagged by different staff members based on release location (i.e., $R_{1}, \ldots, R_{5}$ ) and species (Table A.4). Of the 38 tests of homogeneous reach survivals, 6 were found to be significant at $\alpha=0.10$ (i.e., $15.8 \%$ ). By chance alone, one might expect $10 \%$ of the 38 tests (i.e., 4) to be significant at $\alpha=0.10$ when no effect exists. Similarly, we found 11 of 38 tests of homogeneous cumulative survival to be significant at $\alpha=0.10$ (i.e., $28.9 \%$ ). The percentages of rejections are higher than one might expect to see, but detailed examination of the data indicates no particular pattern to the results. No particular tagger had fish with consistently lower survivals. All taggers had fish releases with the highest and lowest reach survivals. For some unknown reason, there is more heterogeneity among the survival estimates across taggers than expected by binomial change alone, but no identifiable below average taggers were observed. For this reason, all fish tagged by all taggers were included in the subsequent survival analyses. 
Table A.1. Numbers of yearling Chinook salmon and steelhead tagged by each staff member by release location (i.e., $R_{1}, R_{2}, \ldots$ ). Chi-square tests of homogeneity were not significant for a) yearling Chinook salmon or b) steelhead.

a. Combined yearling Chinook salmon and steelhead

\begin{tabular}{cccccccccc}
\hline Release & A & B & C & D & E & F & G & H & $P$-value \\
\hline R1_CR503 & 457 & 297 & 348 & 358 & 288 & 286 & 293 & 472 & \\
R2_CR468 & 361 & 257 & 309 & 309 & 248 & 258 & 249 & 406 & \\
R3_CR422 & 357 & 258 & 311 & 310 & 235 & 262 & 253 & 412 & \\
R4_CR346 & 310 & 222 & 247 & 258 & 190 & 227 & 209 & 334 & \\
R5_CR325 & 306 & 223 & 238 & 259 & 199 & 231 & 207 & 332 & \\
\hline \multicolumn{7}{l}{ Chi-square $=7.8016$} & df = 28
\end{tabular}

b. Yearling Chinook salmon

\begin{tabular}{cccccccccc}
\hline Release & A & B & C & D & E & F & G & H & $P$-value \\
\hline R1_CR503 & 225 & 152 & 172 & 179 & 141 & 145 & 145 & 240 \\
R2_CR468 & 182 & 129 & 155 & 155 & 122 & 127 & 121 & 207 \\
R3_CR422 & 180 & 131 & 157 & 154 & 116 & 131 & 126 & 205 & 170 \\
R4_CR346 & 153 & 112 & 124 & 129 & 94 & 113 & 102 & 170 \\
R5_CR325 & 146 & 115 & 115 & 131 & 101 & 115 & 102 & 17 \\
\hline Chi-square $=4.3024$ & & \multicolumn{2}{c}{$\mathrm{df}=28$} & &
\end{tabular}

c. Steelhead

\begin{tabular}{|c|c|c|c|c|c|c|c|c|c|}
\hline Release & $A$ & $B$ & $C$ & $\mathrm{D}$ & $E$ & $\mathrm{~F}$ & G & $\mathrm{H}$ & $P$-value \\
\hline R1_CR503 & 232 & 145 & 176 & 179 & 147 & 141 & 148 & 232 & \\
\hline R2_CR468 & 179 & 128 & 154 & 154 & 126 & 131 & 128 & 199 & \\
\hline R3_CR422 & 177 & 127 & 154 & 156 & 119 & 131 & 127 & 207 & \\
\hline R4_CR346 & 157 & 110 & 123 & 129 & 96 & 114 & 107 & 164 & \\
\hline R5_CR325 & 160 & 108 & 123 & 128 & 98 & 116 & 105 & 162 & \\
\hline
\end{tabular}


Table A.2. Contingency tables with numbers of yearling Chinook salmon tagged by each staff member per release location within a replicate release. A total of 32 replicate day or night releases were performed over the course of the spring 2012 study. Results of chi-square tests of homogeneity presented in the form of $P$-values.

a. Replicate 1

\begin{tabular}{cccccc}
\hline Release & C & G & E & H & $P$-value \\
\hline R1_CR503 & 10 & 9 & 9 & 16 & 0.9983 \\
R2_CR468 & 10 & 7 & 8 & 12 & \\
R3_CR422 & 10 & 8 & 7 & 12 & \\
\hline R4_CR346 & 9 & 6 & 6 & 11 & \multirow{2}{*}{0.9463} \\
R5_CR325 & 7 & 7 & 6 & 12 & 1
\end{tabular}

b. Replicate 2

\begin{tabular}{cccccccccc}
\hline Release & C & G & E & H & A & B & D & F & $P$-value \\
\hline R1_CR503 & 10 & 9 & 9 & 15 & 0 & 0 & 0 & 0 \\
R2_CR468 & 11 & 6 & 8 & 13 & 0 & 0 & 0 & 0 & 0.9864 \\
R3_CR422 & 12 & 7 & 7 & 12 & 0 & 0 & 0 & 0 \\
\hline R4_CR346 & 0 & 0 & 0 & 0 & 10 & 6 & 9 & 7 & 0.9416 \\
R5_CR325 & 0 & 0 & 0 & 0 & 10 & 7 & 7 & 8 \\
\hline Chi-square $=185.6299$ & & & & & df $=28$ & & & $<0.0001$
\end{tabular}

c. Replicate 3

\begin{tabular}{cccccccccc}
\hline Release & $\mathrm{C}$ & $\mathrm{G}$ & $\mathrm{E}$ & $\mathrm{H}$ & $\mathrm{A}$ & $\mathrm{B}$ & $\mathrm{D}$ & $\mathrm{F}$ & $P$-value \\
\hline R1_CR503 & 11 & 10 & 10 & 12 & 0 & 0 & 0 & 0 & 0 \\
R2_CR468 & 10 & 7 & 8 & 13 & 0 & 0 & 0 & 0.9939 \\
R3_CR422 & 10 & 7 & 8 & 13 & 0 & 0 & 0 & 0 & \\
\hline R4_CR346 & 0 & 0 & 0 & 0 & 10 & 6 & 9 & 7 & 0.9819 \\
R5_CR325 & 0 & 0 & 0 & 0 & 9 & 7 & 8 & 7 & $<0.0001$
\end{tabular}

d. Replicate 4

\begin{tabular}{lccccccccc}
\hline Release & $\mathrm{C}$ & $\mathrm{G}$ & $\mathrm{E}$ & $\mathrm{H}$ & $\mathrm{A}$ & $\mathrm{B}$ & $\mathrm{D}$ & $\mathrm{F}$ & $P$-value \\
\hline R1_CR503 & 11 & 8 & 9 & 16 & 0 & 0 & 0 & 0 & 0 \\
R2_CR468 & 10 & 7 & 7 & 14 & 0 & 0 & 0 & 0.9983 \\
R3_CR422 & 9 & 8 & 6 & 15 & 0 & 0 & 0 & 0 \\
\hline R4_CR346 & 0 & 0 & 0 & 0 & 11 & 7 & 8 & 6 & 0.9827 \\
R5_CR325 & 0 & 0 & 0 & 0 & 10 & 6 & 9 & 6 & $<0.0001$
\end{tabular}


Table A.2. (contd)

e. Replicate 5

\begin{tabular}{crrrrc}
\hline Release & A & B & D & F & $P$-value \\
\hline R1_CR503 & 14 & 9 & 11 & 9 & \\
R2_CR468 & 12 & 8 & 11 & 7 & 0.9999 \\
R3_CR422 & 12 & 8 & 10 & 8 & \\
\hline R4_CR346 & 10 & 7 & 8 & 7 & 0.8918 \\
R5_CR325 & 9 & 9 & 8 & 5 & 1
\end{tabular}

f. Replicate 6

\begin{tabular}{lccccccccc}
\hline Release & C & G & E & H & A & B & D & F & $P$-value \\
\hline R1_CR503 & 0 & 0 & 0 & 0 & 15 & 9 & 13 & 7 & 7 \\
R2_CR468 & 0 & 0 & 0 & 0 & 13 & 8 & 10 & 0.9983 \\
R3_CR422 & 0 & 0 & 0 & 0 & 12 & 8 & 10 & 8 \\
\hline R4_CR346 & 8 & 6 & 7 & 10 & 0 & 0 & 0 & 0 & 0.9799 \\
R5_CR325 & 8 & 7 & 6 & 11 & 0 & 0 & 0 & 0 & $<0.0001$
\end{tabular}

g. $\quad$ Replicate 7

\begin{tabular}{|c|c|c|c|c|c|c|c|c|c|}
\hline Release & $C$ & $\mathrm{G}$ & $E$ & $\mathrm{H}$ & $A$ & $B$ & $\mathrm{D}$ & $\mathrm{F}$ & $P$-value \\
\hline R1_CR503 & 0 & 0 & 0 & 0 & 15 & 10 & 12 & 6 & \multirow{3}{*}{0.9103} \\
\hline R2_CR468 & 0 & 0 & 0 & 0 & 11 & 8 & 10 & 9 & \\
\hline R3_CR422 & 0 & 0 & 0 & 0 & 12 & 6 & 10 & 9 & \\
\hline R4_CR346 & 7 & 6 & 7 & 12 & 0 & 0 & 0 & 0 & \multirow{2}{*}{1} \\
\hline R5_CR325 & 7 & 6 & 7 & 12 & 0 & 0 & 0 & 0 & \\
\hline
\end{tabular}

h. Replicate 8

\begin{tabular}{|c|c|c|c|c|c|c|c|c|c|}
\hline Release & $\mathrm{C}$ & $\mathrm{G}$ & $E$ & $\mathrm{H}$ & $A$ & $\mathrm{~B}$ & $\mathrm{D}$ & $\mathrm{F}$ & P-value \\
\hline R1_CR503 & 0 & 0 & 0 & 0 & 15 & 9 & 11 & 9 & \multirow{3}{*}{0.9999} \\
\hline R2_CR468 & 0 & 0 & 0 & 0 & 13 & 8 & 10 & 7 & \\
\hline R3_CR422 & 0 & 0 & 0 & 0 & 12 & 8 & 9 & 8 & \\
\hline R4_CR346 & 7 & 8 & 5 & 11 & 0 & 0 & 0 & 0 & \multirow{2}{*}{0.8848} \\
\hline R5_CR325 & 7 & 6 & 7 & 10 & 0 & 0 & 0 & 0 & \\
\hline
\end{tabular}

i. $\quad$ Replicate 9

\begin{tabular}{lrrrrc}
\hline Release & C & G & E & H & $P$-value \\
\hline R1_CR503 & 11 & 9 & 8 & 16 & \\
R2_CR468 & 10 & 8 & 7 & 13 & 1 \\
R3_CR422 & 10 & 8 & 7 & 13 & \\
\hline R4_CR346 & 8 & 6 & 6 & 12 & \multirow{2}{*}{0.9667} \\
R5_CR325 & 7 & 7 & 7 & 11 & 1
\end{tabular}


Table A.2. (contd)

j. Replicate 10

\begin{tabular}{lccccccccc}
\hline Release & C & G & E & H & A & B & D & F & $P$-value \\
\hline R1_CR503 & 11 & 9 & 9 & 14 & 0 & 0 & 0 & 0 & 0 \\
R2_CR468 & 10 & 6 & 8 & 14 & 0 & 0 & 0 & 0.9986 \\
R3_CR422 & 9 & 7 & 8 & 13 & 0 & 0 & 0 & 0 & 7 \\
\hline R4_CR346 & 0 & 0 & 0 & 0 & 11 & 6 & 8 & 7 \\
R5_CR325 & 0 & 0 & 0 & 0 & 9 & 7 & 9 & 7 \\
\hline Chi-square $=183.6209$ & & & & & df $=28$ & & & &
\end{tabular}

k. Replicate 11

\begin{tabular}{lccccccccc}
\hline Release & C & G & E & H & A & B & D & F & $P$-value \\
\hline R1_CR503 & 10 & 8 & 10 & 16 & 0 & 0 & 0 & 0 & 0 \\
R2_CR468 & 11 & 9 & 6 & 12 & 0 & 0 & 0 & 0.9633 \\
R3_CR422 & 9 & 7 & 8 & 14 & 0 & 0 & 0 & 0 \\
\hline R4_CR346 & 0 & 0 & 0 & 0 & 9 & 7 & 9 & 7 & 0.9861 \\
R5_CR325 & 0 & 0 & 0 & 0 & 9 & 6 & 9 & 8 & $<0.0001$
\end{tabular}

1. Replicate 12

\begin{tabular}{cccccccccc}
\hline Release & C & G & E & H & A & B & D & F & $P$-value \\
\hline R1_CR503 & 10 & 9 & 7 & 17 & 0 & 0 & 0 & 0 & \\
R2_CR468 & 9 & 9 & 8 & 12 & 0 & 0 & 0 & 0 & 0.9903 \\
R3_CR422 & 8 & 9 & 8 & 13 & 0 & 0 & 0 & 0 & \\
\hline R4_CR346 & 0 & 0 & 0 & 0 & 10 & 7 & 7 & 8 & \multirow{2}{*}{0.8837} \\
R5_CR325 & 0 & 0 & 0 & 0 & 9 & 8 & 9 & 6 & \\
\hline \multicolumn{7}{l}{ Chi-square $=186.2008$} & \multicolumn{7}{c}{$\mathrm{df}=28$} & & & & $<0.0001$
\end{tabular}

m. Replicate 13

\begin{tabular}{cccccc}
\hline Release & A & B & D & F & $P$-value \\
\hline R1_CR503 & 15 & 9 & 10 & 9 & \\
R2_CR468 & 13 & 7 & 10 & 8 & 0.9966 \\
R3_CR422 & 11 & 8 & 11 & 8 & \\
\hline R4_CR346 & 9 & 8 & 8 & 7 & \multirow{2}{*}{0.9970} \\
R5_CR325 & 9 & 8 & 7 & 7 & 0.9999
\end{tabular}

n. Replicate 14

\begin{tabular}{cccccccccc}
\hline Release & C & G & E & H & A & B & D & F & $P$-value \\
\hline R1_CR503 & 0 & 0 & 0 & 0 & 14 & 9 & 11 & 9 & 8 \\
R2_CR468 & 0 & 0 & 0 & 0 & 12 & 8 & 10 & 1 \\
R3_CR422 & 0 & 0 & 0 & 0 & 12 & 8 & 10 & 8 \\
\hline R4_CR346 & 8 & 7 & 6 & 11 & 0 & 0 & 0 & 0 & 0.9861 \\
R5_CR325 & 7 & 7 & 7 & 11 & 0 & 0 & 0 & 0 & $<0.0001$
\end{tabular}


Table A.2. (contd)

o. Replicate 15

\begin{tabular}{|c|c|c|c|c|c|c|c|c|c|}
\hline Release & $\mathrm{C}$ & $\mathrm{G}$ & $E$ & $\mathrm{H}$ & $A$ & $B$ & $\mathrm{D}$ & $\mathrm{F}$ & $P$-value \\
\hline R1_CR503 & 0 & 0 & 0 & 0 & 15 & 9 & 10 & 9 & \multirow{3}{*}{0.9918} \\
\hline R2_CR468 & 0 & 0 & 0 & 0 & 11 & 8 & 10 & 9 & \\
\hline R3_CR422 & 0 & 0 & 0 & 0 & 11 & 10 & 9 & 8 & \\
\hline R4_CR346 & 9 & 7 & 7 & 9 & 0 & 0 & 0 & 0 & \multirow{2}{*}{0.9532} \\
\hline R5_CR325 & 8 & 7 & 6 & 11 & 0 & 0 & 0 & 0 & \\
\hline
\end{tabular}

p. Replicate 16

\begin{tabular}{|c|c|c|c|c|c|c|c|c|c|}
\hline Release & $C$ & $\mathrm{G}$ & $E$ & $\mathrm{H}$ & A & $B$ & $\mathrm{D}$ & $\mathrm{F}$ & $P$-value \\
\hline R1_CR503 & 0 & 0 & 0 & 0 & 16 & 9 & 11 & 8 & \multirow{3}{*}{0.9881} \\
\hline R2_CR468 & 0 & 0 & 0 & 0 & 10 & 9 & 10 & 8 & \\
\hline R3_CR422 & 0 & 0 & 0 & 0 & 12 & 9 & 9 & 8 & \\
\hline R4_CR346 & 8 & 6 & 6 & 12 & 0 & 0 & 0 & 0 & \multirow{2}{*}{0.9532} \\
\hline R5_CR325 & 8 & 7 & 7 & 10 & 0 & 0 & 0 & 0 & \\
\hline
\end{tabular}

q. Replicate 17

\begin{tabular}{lrrrrc}
\hline \multicolumn{1}{c}{ Release } & C & G & E & H & $P$-value \\
\hline R1_CR503 & 11 & 9 & 9 & 15 & \\
R2_CR468 & 9 & 8 & 9 & 11 & 0.9957 \\
R3_CR422 & 10 & 9 & 7 & 11 & \\
\hline R4_CR346 & 9 & 6 & 6 & 11 & \multirow{2}{*}{0.9872} \\
R5_CR325 & 8 & 6 & 7 & 11 & 1
\end{tabular}

r. Replicate 18

\begin{tabular}{|c|c|c|c|c|c|c|c|c|c|}
\hline Release & $C$ & $\mathrm{G}$ & $E$ & $\mathrm{H}$ & $\mathrm{A}$ & $B$ & $\mathrm{D}$ & $\mathrm{F}$ & $P$-value \\
\hline R1_CR503 & 11 & 10 & 7 & 15 & 0 & 0 & 0 & 0 & \multirow{3}{*}{0.9945} \\
\hline R2_CR468 & 10 & 8 & 8 & 12 & 0 & 0 & 0 & 0 & \\
\hline R3_CR422 & 11 & 8 & 8 & 11 & 0 & 0 & 0 & 0 & \\
\hline R4_CR346 & 0 & 0 & 0 & 0 & 10 & 7 & 8 & 7 & \multirow{2}{*}{0.9493} \\
\hline R5_CR325 & 0 & 0 & 0 & 0 & 8 & 8 & 8 & 8 & \\
\hline
\end{tabular}

S. Replicate 19

\begin{tabular}{lccccccccc}
\hline Release & C & G & E & H & A & B & D & F & $P$-value \\
\hline R1_CR503 & 11 & 9 & 9 & 14 & 0 & 0 & 0 & 0 & 0 \\
R2_CR468 & 10 & 6 & 8 & 13 & 0 & 0 & 0 & 0.9985 \\
R3_CR422 & 9 & 7 & 8 & 14 & 0 & 0 & 0 & 0 \\
\hline R4_CR346 & 0 & 0 & 0 & 0 & 8 & 9 & 7 & 7 & 0.8110 \\
R5_CR325 & 0 & 0 & 0 & 0 & 9 & 6 & 9 & 8 & $<0.0001$
\end{tabular}


Table A.2. (contd)

t. Replicate 20

\begin{tabular}{|c|c|c|c|c|c|c|c|c|c|}
\hline Release & $\mathrm{C}$ & $\mathrm{G}$ & $E$ & $\mathrm{H}$ & $A$ & $B$ & $\mathrm{D}$ & $\mathrm{F}$ & $P$-value \\
\hline R1_CR503 & 12 & 9 & 9 & 14 & 0 & 0 & 0 & 0 & \multirow{3}{*}{0.9998} \\
\hline R2_CR468 & 9 & 8 & 8 & 13 & 0 & 0 & 0 & 0 & \\
\hline R3_CR422 & 10 & 8 & 7 & 12 & 0 & 0 & 0 & 0 & \\
\hline R4_CR346 & 0 & 0 & 0 & 0 & 9 & 7 & 9 & 7 & \multirow{2}{*}{0.9437} \\
\hline R5_CR325 & 0 & 0 & 0 & 0 & 9 & 8 & 7 & 8 & \\
\hline
\end{tabular}

u. Replicate 21

\begin{tabular}{lrrrrc}
\hline \multicolumn{1}{c}{ Release } & A & B & D & F & $P$-value \\
\hline R1_CR503 & 14 & 9 & 11 & 9 & \\
R2_CR468 & 12 & 8 & 9 & 9 & 0.9998 \\
R3_CR422 & 12 & 9 & 9 & 8 & \\
\hline R4_CR346 & 10 & 7 & 7 & 7 & \multirow{2}{*}{0.9625} \\
R5_CR325 & 9 & 7 & 9 & 7 & 1
\end{tabular}

v. Replicate 22

\begin{tabular}{llllllrrrr}
\hline Release & C & G & E & H & A & B & D & F & $P$-value \\
\hline R1_CR503 & 0 & 0 & 0 & 0 & 13 & 10 & 11 & 10 & 8 \\
R2_CR468 & 0 & 0 & 0 & 0 & 12 & 8 & 10 & 0.9994 \\
R3_CR422 & 0 & 0 & 0 & 0 & 10 & 9 & 10 & 9 \\
\hline R4_CR346 & 8 & 7 & 6 & 11 & 0 & 0 & 0 & 0 & 0.9847 \\
R5_CR325 & 8 & 6 & 7 & 11 & 0 & 0 & 0 & 0 & $<0.0001$
\end{tabular}

w. Replicate 23

\begin{tabular}{cccccccccc}
\hline Release & C & G & E & H & A & B & D & F & $P$-value \\
\hline R1_CR503 & 0 & 0 & 0 & 0 & 14 & 8 & 11 & 11 & 9 \\
R2_CR468 & 0 & 0 & 0 & 0 & 11 & 8 & 10 & 0.9884 \\
R3_CR422 & 0 & 0 & 0 & 0 & 11 & 9 & 11 & 7 & 0 \\
\hline R4_CR346 & 7 & 7 & 7 & 11 & 0 & 0 & 0 & 0 & 0.9861 \\
R5_CR325 & 8 & 7 & 6 & 11 & 0 & 0 & 0 & 0 \\
\hline Chi-square $=185.8277$ & & & & & df $=28$ & & &
\end{tabular}

x. Replicate 24

\begin{tabular}{llllllrrrr}
\hline Release & C & G & E & H & A & B & D & F & P-value \\
\hline R1_CR503 & 0 & 0 & 0 & 0 & 13 & 10 & 11 & 10 & 9 \\
R2_CR468 & 0 & 0 & 0 & 0 & 11 & 9 & 9 & 1 \\
R3_CR422 & 0 & 0 & 0 & 0 & 11 & 9 & 10 & 8 \\
\hline R4_CR346 & 8 & 7 & 6 & 11 & 0 & 0 & 0 & 0 & 0.9847 \\
R5_CR325 & 8 & 6 & 7 & 11 & 0 & 0 & 0 & 0 & $<0.0001$
\end{tabular}


Table A.2. (contd)

y. Replicate 25

\begin{tabular}{lrrrrc}
\hline \multicolumn{1}{c}{ Release } & \multicolumn{1}{c}{ C } & G & E & H & $P$-value \\
\hline R1_CR503 & 11 & 10 & 10 & 13 & \\
R2_CR468 & 9 & 8 & 7 & 14 & 0.9948 \\
R3_CR422 & 10 & 8 & 7 & 13 & \\
\hline R4_CR346 & 8 & 7 & 6 & 11 & 1 \\
R5_CR325 & 8 & 7 & 6 & 11 & 1 \\
\hline Chi-square $=0.7352$ & & $\mathrm{df}=12$ & &
\end{tabular}

z. Replicate 26

\begin{tabular}{|c|c|c|c|c|c|c|c|c|c|}
\hline Release & $\mathrm{C}$ & $\mathrm{G}$ & $E$ & $\mathrm{H}$ & A & $B$ & D & $\mathrm{F}$ & $P$-value \\
\hline R1_CR503 & 11 & 9 & 9 & 15 & 0 & 0 & 0 & 0 & \multirow{3}{*}{0.9937} \\
\hline R2_CR468 & 8 & 8 & 8 & 14 & 0 & 0 & 0 & 0 & \\
\hline R3_CR422 & 10 & 9 & 6 & 13 & 0 & 0 & 0 & 0 & \\
\hline R4_CR346 & 0 & 0 & 0 & 0 & 8 & 7 & 8 & 7 & \multirow{2}{*}{0.9977} \\
\hline R5_CR325 & 0 & 0 & 0 & 0 & 9 & 7 & 8 & 7 & \\
\hline
\end{tabular}

aa. Replicate 27

\begin{tabular}{|c|c|c|c|c|c|c|c|c|c|}
\hline Release & $\mathrm{C}$ & $\mathrm{G}$ & $E$ & $\mathrm{H}$ & $A$ & $B$ & $\mathrm{D}$ & $\mathrm{F}$ & $P$-value \\
\hline R1_CR503 & 11 & 9 & 9 & 15 & 0 & 0 & 0 & 0 & \multirow{3}{*}{0.9999} \\
\hline R2_CR468 & 9 & 8 & 7 & 14 & 0 & 0 & 0 & 0 & \\
\hline R3_CR422 & 10 & 8 & 7 & 13 & 0 & 0 & 0 & 0 & \\
\hline R4_CR346 & 0 & 0 & 0 & 0 & 9 & 6 & 8 & 8 & \multirow{2}{*}{0.9807} \\
\hline R5_CR325 & 0 & 0 & 0 & 0 & 10 & 7 & 8 & 7 & \\
\hline
\end{tabular}

bb. Replicate 28

\begin{tabular}{cccccccccc}
\hline Release & C & G & E & H & A & B & D & F & P-value \\
\hline R1_CR503 & 10 & 9 & 8 & 17 & 0 & 0 & 0 & 0 & 0 \\
R2_CR468 & 10 & 8 & 7 & 13 & 0 & 0 & 0 & 0.9995 \\
R3_CR422 & 10 & 8 & 7 & 13 & 0 & 0 & 0 & 0 \\
\hline R4_CR346 & 0 & 0 & 0 & 0 & 10 & 8 & 8 & 6 & 0.9392 \\
R5_CR325 & 0 & 0 & 0 & 0 & 9 & 7 & 8 & 8 & $<0.0001$
\end{tabular}

cc. Replicate 29

\begin{tabular}{crrrrc}
\hline Release & A & \multicolumn{1}{c}{ B } & D & F & $P$-value \\
\hline R1_CR503 & 13 & 10 & 11 & 10 & \\
R2_CR468 & 11 & 9 & 10 & 7 & 0.9992 \\
R3_CR422 & 11 & 8 & 10 & 9 & \\
R4_CR346 & 9 & 7 & 8 & 8 & 1 \\
R5_CR325 & 9 & 7 & 8 & 8 & 1 \\
\hline Chi-square $=0.5707$ & & $\mathrm{df}=12$ & & 1
\end{tabular}


Table A.2. (contd)

dd. Replicate 30

\begin{tabular}{|c|c|c|c|c|c|c|c|c|c|}
\hline Release & $C$ & $\mathrm{G}$ & $E$ & $\mathrm{H}$ & $A$ & $B$ & $\mathrm{D}$ & $\mathrm{F}$ & $P$-value \\
\hline R1_CR503 & 0 & 0 & 0 & 0 & 13 & 10 & 12 & 9 & \multirow{3}{*}{0.9999} \\
\hline R2_CR468 & 0 & 0 & 0 & 0 & 11 & 8 & 10 & 9 & \\
\hline R3_CR422 & 0 & 0 & 0 & 0 & 11 & 8 & 10 & 9 & \\
\hline R4_CR346 & 9 & 7 & 4 & 12 & 0 & 0 & 0 & 0 & \multirow{2}{*}{0.7768} \\
\hline R5_CR325 & 6 & 6 & 6 & 13 & 0 & 0 & 0 & 0 & \\
\hline
\end{tabular}

ee. Replicate 31

\begin{tabular}{lccccrrrrr}
\hline Release & C & G & E & H & A & B & D & F & $P$-value \\
\hline R1_CR503 & 0 & 0 & 0 & 0 & 14 & 11 & 12 & 10 & 7 \\
R2_CR468 & 0 & 0 & 0 & 0 & 9 & 8 & 8 & 0.9998 \\
R3_CR422 & 0 & 0 & 0 & 0 & 10 & 7 & 8 & 8 \\
\hline R4_CR346 & 6 & 4 & 5 & 8 & 0 & 0 & 0 & 0 & 0.9460 \\
R5_CR325 & 5 & 5 & 4 & 9 & 0 & 0 & 0 & 0 & \multirow{2}{*}{ df = 28 } \\
\hline Chi-square $=159.5936$ & & & & & &
\end{tabular}

ff. Replicate 32

\begin{tabular}{|c|c|c|c|c|c|c|c|c|c|}
\hline Release & $C$ & $G$ & $E$ & $\mathrm{H}$ & $A$ & $\mathrm{~B}$ & $\mathrm{D}$ & $\mathrm{F}$ & $P$-value \\
\hline R1_CR503 & 0 & 0 & 0 & 0 & 12 & 11 & 11 & 10 & \multirow{3}{*}{0.9981} \\
\hline R2_CR468 & 0 & 0 & 0 & 0 & 10 & 7 & 8 & 6 & \\
\hline R3_CR422 & 0 & 0 & 0 & 0 & 10 & 7 & 8 & 8 & \\
\hline R4_CR346 & 5 & 5 & 4 & 7 & 0 & 0 & 0 & 0 & \multirow{2}{*}{0.9360} \\
\hline R5_CR325 & 5 & 5 & 5 & 5 & 0 & 0 & 0 & 0 & \\
\hline
\end{tabular}


Table A.3. Contingency tables with numbers of steelhead tagged by each staff member per release location within a replicate release. A total of 32 replicate day or nighttime releases were performed over the course of the spring 2012 study. Results of chi-square tests of homogeneity are presented in the form of $P$-values.

a. Replicate 1

\begin{tabular}{crrrrc}
\hline Release & C & G & E & H & $P$-value \\
\hline R1_CR503 & 11 & 8 & 10 & 15 & \\
R2_CR468 & 10 & 7 & 8 & 12 & 0.9993 \\
R3_CR422 & 10 & 8 & 7 & 13 & \\
\hline R4_CR346 & 8 & 6 & 7 & 11 & 1 \\
R5_CR325 & 8 & 6 & 7 & 11 & 1 \\
\hline Chi-square $=0.3823$ & & $\mathrm{df}=12$ & & & 1
\end{tabular}

b. Replicate 2

\begin{tabular}{lccccccccc}
\hline Release & C & G & E & H & A & B & D & F & $P$-value \\
\hline R1_CR503 & 10 & 8 & 10 & 16 & 0 & 0 & 0 & 0 \\
R2_CR468 & 9 & 7 & 8 & 14 & 0 & 0 & 0 & 0 & 1 \\
R3_CR422 & 9 & 7 & 8 & 14 & 0 & 0 & 0 & 0 \\
\hline R4_CR346 & 0 & 0 & 0 & 0 & 11 & 7 & 8 & 6 & 0.9872 \\
R5_CR325 & 0 & 0 & 0 & 0 & 11 & 6 & 9 & 6 & $<0.0001$
\end{tabular}

c. Replicate 3

\begin{tabular}{lccccccccc}
\hline Release & C & G & E & H & A & B & D & F & $P$-value \\
\hline R1_CR503 & 12 & 9 & 11 & 12 & 0 & 0 & 0 & 0 \\
R2_CR468 & 9 & 8 & 7 & 14 & 0 & 0 & 0 & 0 & 0.9600 \\
R3_CR422 & 9 & 8 & 7 & 14 & 0 & 0 & 0 & 0 \\
\hline R4_CR346 & 0 & 0 & 0 & 0 & 11 & 7 & 8 & 6 & 0.9667 \\
R5_CR325 & 0 & 0 & 0 & 0 & 12 & 6 & 7 & 7 & $<0.0001$
\end{tabular}

d. Replicate 4

\begin{tabular}{lccccccccc}
\hline Release & C & G & E & H & A & B & D & F & $P$-value \\
\hline R1_CR503 & 11 & 9 & 10 & 14 & 0 & 0 & 0 & 0 \\
R2_CR468 & 9 & 8 & 8 & 13 & 0 & 0 & 0 & 0 & 1 \\
R3_CR422 & 9 & 8 & 8 & 13 & 0 & 0 & 0 & 0 \\
\hline R4_CR346 & 0 & 0 & 0 & 0 & 11 & 6 & 7 & 7 & 0.9970 \\
R5_CR325 & 0 & 0 & 0 & 0 & 11 & 6 & 8 & 7 & $<0.0001$
\end{tabular}


Table A.3. (contd)

e. Replicate 5

\begin{tabular}{lccccc}
\hline Release & A & B & D & F & $P$-value \\
\hline R1_CR503 & 15 & 8 & 12 & 9 & \\
R2_CR468 & 12 & 9 & 10 & 7 & 0.9985 \\
R3_CR422 & 12 & 8 & 10 & 8 & \\
\hline R4_CR346 & 11 & 6 & 8 & 6 & \multirow{2}{*}{0.9768} \\
R5_CR325 & 11 & 7 & 7 & 7 & 1
\end{tabular}

f. Replicate 6

\begin{tabular}{|c|c|c|c|c|c|c|c|c|c|}
\hline Release & $C$ & $\mathrm{G}$ & $E$ & $\mathrm{H}$ & A & $B$ & $\mathrm{D}$ & $\mathrm{F}$ & $P$-value \\
\hline R1_CR503 & 0 & 0 & 0 & 0 & 15 & 8 & 11 & 9 & \multirow{3}{*}{0.9998} \\
\hline R2_CR468 & 0 & 0 & 0 & 0 & 13 & 8 & 9 & 8 & \\
\hline R3_CR422 & 0 & 0 & 0 & 0 & 13 & 7 & 10 & 7 & \\
\hline R4_CR346 & 9 & 6 & 6 & 11 & 0 & 0 & 0 & 0 & \multirow{2}{*}{0.9419} \\
\hline R5_CR325 & 8 & 6 & 8 & 10 & 0 & 0 & 0 & 0 & \\
\hline
\end{tabular}

g. $\quad$ Replicate 7

\begin{tabular}{cccccccccc}
\hline Release & C & G & E & H & A & B & D & F & $P$-value \\
\hline R1_CR503 & 0 & 0 & 0 & 0 & 14 & 10 & 11 & 9 \\
R2_CR468 & 0 & 0 & 0 & 0 & 12 & 7 & 10 & 9 & 0.9980 \\
R3_CR422 & 0 & 0 & 0 & 0 & 12 & 7 & 11 & 8 & 0 \\
\hline R4_CR346 & 7 & 7 & 6 & 12 & 0 & 0 & 0 & 0 \\
R5_CR325 & 8 & 7 & 6 & 11 & 0 & 0 & 0 & 0 & 0.9906 \\
\hline Chi-square $=185.0656$ & & & & $\mathrm{df}=28$ & & & $<0.0001$
\end{tabular}

h. Replicate 8

\begin{tabular}{|c|c|c|c|c|c|c|c|c|c|}
\hline Release & $C$ & $\mathrm{G}$ & $E$ & $\mathrm{H}$ & $\mathrm{A}$ & $\mathrm{B}$ & $\mathrm{D}$ & $\mathrm{F}$ & $P$-value \\
\hline R1_CR503 & 0 & 0 & 0 & 0 & 14 & 9 & 12 & 9 & \multirow{3}{*}{0.9999} \\
\hline R2_CR468 & 0 & 0 & 0 & 0 & 12 & 7 & 11 & 8 & \\
\hline R3_CR422 & 0 & 0 & 0 & 0 & 13 & 7 & 10 & 8 & \\
\hline R4_CR346 & 8 & 7 & 6 & 11 & 0 & 0 & 0 & 0 & \multirow{2}{*}{0.9847} \\
\hline R5_CR325 & 8 & 6 & 7 & 11 & 0 & 0 & 0 & 0 & \\
\hline
\end{tabular}


Table A.3. (contd)

i. Replicate 9

\begin{tabular}{lrrrrr}
\hline Release & C & G & E & H & $P$-value \\
\hline R1_CR503 & 11 & 9 & 9 & 15 & \\
R2_CR468 & 9 & 9 & 8 & 12 & 0.9974 \\
R3_CR422 & 10 & 7 & 7 & 14 & \\
\hline R4_CR346 & 7 & 7 & 6 & 11 & \multirow{2}{*}{0.9970} \\
R5_CR325 & 8 & 7 & 6 & 11 & 1
\end{tabular}

j. Replicate 10

\begin{tabular}{|c|c|c|c|c|c|c|c|c|c|}
\hline Release & $C$ & $\mathrm{G}$ & $E$ & $\mathrm{H}$ & $A$ & $B$ & $D$ & $\mathrm{~F}$ & $P$-value \\
\hline R1_CR503 & 11 & 10 & 9 & 14 & 0 & 0 & 0 & 0 & \multirow{3}{*}{0.9986} \\
\hline R2_CR468 & 11 & 8 & 8 & 11 & 0 & 0 & 0 & 0 & \\
\hline R3_CR422 & 9 & 8 & 8 & 13 & 0 & 0 & 0 & 0 & \\
\hline R4_CR346 & 0 & 0 & 0 & 0 & 10 & 7 & 8 & 7 & \multirow{2}{*}{1} \\
\hline R5_CR325 & 0 & 0 & 0 & 0 & 10 & 7 & 8 & 7 & \\
\hline
\end{tabular}

k. Replicate 11

\begin{tabular}{|c|c|c|c|c|c|c|c|c|c|}
\hline Release & $C$ & $\mathrm{G}$ & $\mathrm{E}$ & $\mathrm{H}$ & $A$ & B & $\mathrm{D}$ & $\mathrm{F}$ & $P$-value \\
\hline R1_CR503 & 11 & 9 & 9 & 15 & 0 & 0 & 0 & 0 & \multirow{3}{*}{0.9974} \\
\hline R2_CR468 & 10 & 8 & 8 & 12 & 0 & 0 & 0 & 0 & \\
\hline R3_CR422 & 9 & 9 & 6 & 13 & 0 & 0 & 0 & 0 & \\
\hline R4_CR346 & 0 & 0 & 0 & 0 & 11 & 6 & 8 & 7 & \multirow{2}{*}{0.9516} \\
\hline R5_CR325 & 0 & 0 & 0 & 0 & 9 & 7 & 8 & 8 & \\
\hline \multicolumn{4}{|c|}{ Chi-square $=184.8016$} & \multicolumn{2}{|c|}{$d f=28$} & & & & $<0.0001$ \\
\hline
\end{tabular}

1. Replicate 12

\begin{tabular}{|c|c|c|c|c|c|c|c|c|c|}
\hline Release & $\mathrm{C}$ & $\mathrm{G}$ & $\mathrm{E}$ & $\mathrm{H}$ & $\mathrm{A}$ & $B$ & $\mathrm{D}$ & $\mathrm{F}$ & $P$-value \\
\hline R1_CR503 & 10 & 10 & 9 & 14 & 0 & 0 & 0 & 0 & \multirow{3}{*}{0.9976} \\
\hline R2_CR468 & 10 & 7 & 8 & 13 & 0 & 0 & 0 & 0 & \\
\hline R3_CR422 & 9 & 7 & 8 & 14 & 0 & 0 & 0 & 0 & \\
\hline R4_CR346 & 0 & 0 & 0 & 0 & 11 & 6 & 8 & 7 & \multirow{2}{*}{0.9887} \\
\hline R5_CR325 & 0 & 0 & 0 & 0 & 10 & 7 & 8 & 7 & \\
\hline
\end{tabular}


Table A.3. (contd)

m. Replicate 13

\begin{tabular}{lrrrrc}
\hline \multicolumn{1}{c}{ Release } & A & B & D & F & $P$-value \\
\hline R1_CR503 & 15 & 10 & 10 & 9 & \\
R2_CR468 & 12 & 8 & 10 & 8 & 0.9976 \\
R3_CR422 & 11 & 8 & 11 & 8 & \\
\hline R4_CR346 & 9 & 7 & 9 & 7 & \multirow{2}{*}{0.9904} \\
R5_CR325 & 10 & 7 & 8 & 7 & 1
\end{tabular}

n. Replicate 14

\begin{tabular}{|c|c|c|c|c|c|c|c|c|c|}
\hline Release & $\mathrm{C}$ & $\mathrm{G}$ & $\mathrm{E}$ & $\mathrm{H}$ & $\mathrm{A}$ & $\mathrm{B}$ & $\mathrm{D}$ & $\mathrm{F}$ & $P$-value \\
\hline R1_CR503 & 0 & 0 & 0 & 0 & 15 & 9 & 11 & 9 & \multirow{3}{*}{0.9999} \\
\hline R2_CR468 & 0 & 0 & 0 & 0 & 12 & 8 & 10 & 8 & \\
\hline R3_CR422 & 0 & 0 & 0 & 0 & 11 & 8 & 10 & 8 & \\
\hline R4_CR346 & 7 & 7 & 7 & 11 & 0 & 0 & 0 & 0 & \multirow{2}{*}{0.9861} \\
\hline R5_CR325 & 8 & 7 & 6 & 11 & 0 & 0 & 0 & 0 & \\
\hline
\end{tabular}

o. Replicate 15

\begin{tabular}{llllllrrrr}
\hline Release & C & G & E & H & A & B & D & F & P-value \\
\hline R1_CR503 & 0 & 0 & 0 & 0 & 15 & 9 & 12 & 8 & 9 \\
R2_CR468 & 0 & 0 & 0 & 0 & 11 & 8 & 10 & 0.9691 \\
R3_CR422 & 0 & 0 & 0 & 0 & 11 & 10 & 8 & 9 \\
\hline R4_CR346 & 7 & 8 & 7 & 9 & 0 & 0 & 0 & 0 & 0.9027 \\
R5_CR325 & 9 & 6 & 7 & 10 & 0 & 0 & 0 & 0 & $<0.0001$
\end{tabular}

p. Replicate 16

\begin{tabular}{|c|c|c|c|c|c|c|c|c|c|}
\hline Release & $C$ & $\mathrm{G}$ & $E$ & $\mathrm{H}$ & $A$ & B & $\mathrm{D}$ & $\mathrm{F}$ & $P$-value \\
\hline R1_CR503 & 0 & 0 & 0 & 0 & 14 & 9 & 12 & 9 & \multirow{3}{*}{0.9361} \\
\hline R2_CR468 & 0 & 0 & 0 & 0 & 8 & 10 & 11 & 9 & \\
\hline R3_CR422 & 0 & 0 & 0 & 0 & 12 & 7 & 10 & 9 & \\
\hline R4_CR346 & 9 & 7 & 6 & 10 & 0 & 0 & 0 & 0 & \multirow{2}{*}{0.9886} \\
\hline R5_CR325 & 8 & 8 & 6 & 10 & 0 & 0 & 0 & 0 & \\
\hline
\end{tabular}


Table A.3. (contd)

q. Replicate 17

\begin{tabular}{cccccc}
\hline Release & C & G & E & H & $P$-value \\
\hline R1_CR503 & 12 & 9 & 8 & 15 & \\
R2_CR468 & 10 & 9 & 9 & 10 & 0.9882 \\
R3_CR422 & 10 & 9 & 7 & 12 & \\
\hline R4_CR346 & 8 & 7 & 6 & 11 & \multirow{2}{*}{0.9911} \\
R5_CR325 & 9 & 7 & 6 & 10 & 1
\end{tabular}

r. Replicate 18

\begin{tabular}{cccccccccc}
\hline Release & C & G & E & H & A & B & D & F & $P$-value \\
\hline R1_CR503 & 11 & 9 & 10 & 14 & 0 & 0 & 0 & 0 \\
R2_CR468 & 10 & 7 & 8 & 13 & 0 & 0 & 0 & 0 & 0.9994 \\
R3_CR422 & 10 & 8 & 7 & 13 & 0 & 0 & 0 & 0 \\
\hline R4_CR346 & 0 & 0 & 0 & 0 & 9 & 7 & 8 & 8 & 0.9894 \\
R5_CR325 & 0 & 0 & 0 & 0 & 10 & 7 & 8 & 7 & $<0.0001$
\end{tabular}

S. Replicate 19

\begin{tabular}{|c|c|c|c|c|c|c|c|c|c|}
\hline Release & $\mathrm{C}$ & $\mathrm{G}$ & $E$ & $\mathrm{H}$ & $\mathrm{A}$ & $\mathrm{B}$ & $\mathrm{D}$ & $\mathrm{F}$ & $P$-value \\
\hline R1_CR503 & 11 & 9 & 9 & 15 & 0 & 0 & 0 & 0 & \multirow{3}{*}{0.9998} \\
\hline R2_CR468 & 9 & 9 & 8 & 12 & 0 & 0 & 0 & 0 & \\
\hline R3_CR422 & 10 & 8 & 8 & 12 & 0 & 0 & 0 & 0 & \\
\hline R4_CR346 & 0 & 0 & 0 & 0 & 9 & 9 & 7 & 7 & \multirow{2}{*}{0.9465} \\
\hline R5_CR325 & 0 & 0 & 0 & 0 & 10 & 7 & 7 & 8 & \\
\hline
\end{tabular}

t. Replicate 20

\begin{tabular}{|c|c|c|c|c|c|c|c|c|c|}
\hline Release & C & $\mathrm{G}$ & $E$ & $\mathrm{H}$ & $A$ & $B$ & $D$ & $\mathrm{~F}$ & $P$-value \\
\hline R1_CR503 & 11 & 10 & 9 & 14 & 0 & 0 & 0 & 0 & \multirow{3}{*}{0.9941} \\
\hline R2_CR468 & 9 & 8 & 7 & 14 & 0 & 0 & 0 & 0 & \\
\hline R3_CR422 & 11 & 9 & 7 & 11 & 0 & 0 & 0 & 0 & \\
\hline R4_CR346 & 0 & 0 & 0 & 0 & 8 & 7 & 9 & 8 & \multirow{2}{*}{0.9508} \\
\hline R5_CR325 & 0 & 0 & 0 & 0 & 10 & 7 & 8 & 7 & \\
\hline
\end{tabular}


Table A.3. (contd)

u. Replicate 21

\begin{tabular}{cccccc}
\hline Release & A & B & D & F & $P$-value \\
\hline R1_CR503 & 16 & 9 & 11 & 8 & \\
R2_CR468 & 11 & 8 & 10 & 8 & 0.9925 \\
R3_CR422 & 11 & 8 & 10 & 9 & \\
\hline R4_CR346 & 10 & 7 & 8 & 7 & 1 \\
R5_CR325 & 10 & 7 & 8 & 7 & 1
\end{tabular}

v. Replicate 22

\begin{tabular}{cccccccccc}
\hline Release & C & G & E & H & A & B & D & F & $P$-value \\
\hline R1_CR503 & 0 & 0 & 0 & 0 & 15 & 10 & 10 & 9 \\
R2_CR468 & 0 & 0 & 0 & 0 & 11 & 8 & 10 & 9 & 0.9972 \\
R3_CR422 & 0 & 0 & 0 & 0 & 11 & 8 & 10 & 9 \\
\hline R4_CR346 & 9 & 7 & 6 & 10 & 0 & 0 & 0 & 0 & 0.9872 \\
R5_CR325 & 8 & 7 & 7 & 10 & 0 & 0 & 0 & 0 \\
\hline Chi-square $=185.2304$ & & & & df $=28$ & & & $<0.0001$
\end{tabular}

w. Replicate 23

\begin{tabular}{|c|c|c|c|c|c|c|c|c|c|}
\hline Release & $C$ & $\mathrm{G}$ & $E$ & $\mathrm{H}$ & $A$ & $\mathrm{~B}$ & $\mathrm{D}$ & $\mathrm{F}$ & $P$-value \\
\hline R1_CR503 & 0 & 0 & 0 & 0 & 15 & 9 & 11 & 9 & \multirow{3}{*}{0.9804} \\
\hline R2_CR468 & 0 & 0 & 0 & 0 & 11 & 8 & 9 & 10 & \\
\hline R3_CR422 & 0 & 0 & 0 & 0 & 10 & 9 & 11 & 8 & \\
\hline R4_CR346 & 8 & 7 & 6 & 11 & 0 & 0 & 0 & 0 & \multirow{2}{*}{0.9901} \\
\hline R5_CR325 & 8 & 8 & 6 & 10 & 0 & 0 & 0 & 0 & \\
\hline
\end{tabular}

x. Replicate 24

\begin{tabular}{|c|c|c|c|c|c|c|c|c|c|}
\hline Release & C & $\mathrm{G}$ & $E$ & $\mathrm{H}$ & $A$ & $B$ & $\mathrm{D}$ & $\mathrm{F}$ & $P$-value \\
\hline R1_CR503 & 0 & 0 & 0 & 0 & 15 & 9 & 11 & 9 & \multirow{3}{*}{0.9948} \\
\hline R2_CR468 & 0 & 0 & 0 & 0 & 11 & 9 & 10 & 8 & \\
\hline R3_CR422 & 0 & 0 & 0 & 0 & 10 & 9 & 10 & 9 & \\
\hline R4_CR346 & 8 & 7 & 7 & 10 & 0 & 0 & 0 & 0 & \multirow{2}{*}{0.9887} \\
\hline R5_CR325 & 8 & 7 & 6 & 11 & 0 & 0 & 0 & 0 & \\
\hline
\end{tabular}


Table A.3. (contd)

y. Replicate 25

\begin{tabular}{lrrrrc}
\hline Release & C & G & E & H & $P$-value \\
\hline R1_CR503 & 12 & 10 & 8 & 14 & \\
R2_CR468 & 10 & 8 & 8 & 12 & 0.9992 \\
R3_CR422 & 10 & 7 & 8 & 13 & \\
\hline R4_CR346 & 8 & 7 & 6 & 11 & \multirow{2}{*}{0.9876} \\
R5_CR325 & 7 & 8 & 6 & 11 & 1
\end{tabular}

z. Replicate 26

\begin{tabular}{|c|c|c|c|c|c|c|c|c|c|}
\hline Release & $C$ & $\mathrm{G}$ & $E$ & $\mathrm{H}$ & A & $B$ & $\mathrm{D}$ & $\mathrm{F}$ & $P$-value \\
\hline R1_CR503 & 11 & 9 & 9 & 15 & 0 & 0 & 0 & 0 & \multirow{3}{*}{0.9987} \\
\hline R2_CR468 & 8 & 9 & 8 & 13 & 0 & 0 & 0 & 0 & \\
\hline R3_CR422 & 10 & 8 & 7 & 13 & 0 & 0 & 0 & 0 & \\
\hline R4_CR346 & 0 & 0 & 0 & 0 & 8 & 7 & 9 & 8 & \multirow{2}{*}{0.9488} \\
\hline R5_CR325 & 0 & 0 & 0 & 0 & 10 & 6 & 8 & 8 & \\
\hline
\end{tabular}

aa. Replicate 27

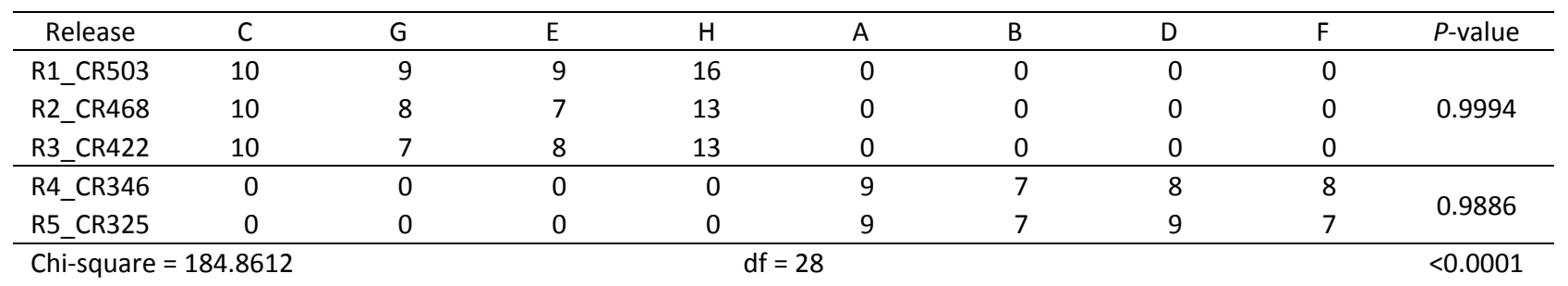

bb. Replicate 28

\begin{tabular}{cccccccccc}
\hline Release & C & G & E & H & A & B & D & F & $P$-value \\
\hline R1_CR503 & 11 & 11 & 8 & 14 & 0 & 0 & 0 & 0 & 0 \\
R2_CR468 & 11 & 8 & 8 & 11 & 0 & 0 & 0 & 0.9973 \\
R3_CR422 & 9 & 9 & 8 & 12 & 0 & 0 & 0 & 0 \\
\hline R4_CR346 & 0 & 0 & 0 & 0 & 9 & 7 & 8 & 8 & 1 \\
R5_CR325 & 0 & 0 & 0 & 0 & 9 & 7 & 8 & 8 & $<0.0001$
\end{tabular}


Table A.3. (contd)

cc. Replicate 29

\begin{tabular}{lrrrrc}
\hline Release & A & B & D & F & $P$-value \\
\hline R1_CR503 & 14 & 9 & 11 & 10 & \\
R2_CR468 & 12 & 8 & 10 & 8 & 0.9998 \\
R3_CR422 & 11 & 9 & 10 & 8 & \\
\hline R4_CR346 & 10 & 7 & 8 & 7 & \multirow{2}{*}{0.9508} \\
R5_CR325 & 8 & 7 & 9 & 8 & 1
\end{tabular}

dd. Replicate 30

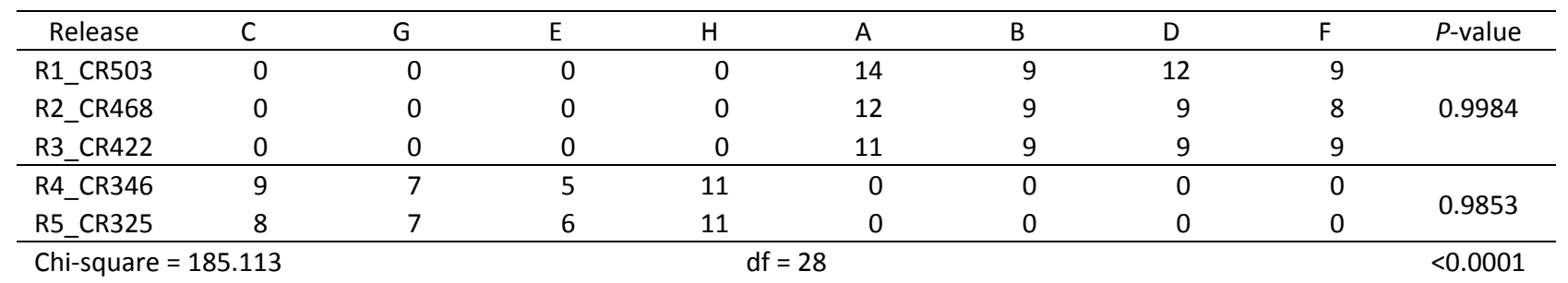

ee. Replicate 31

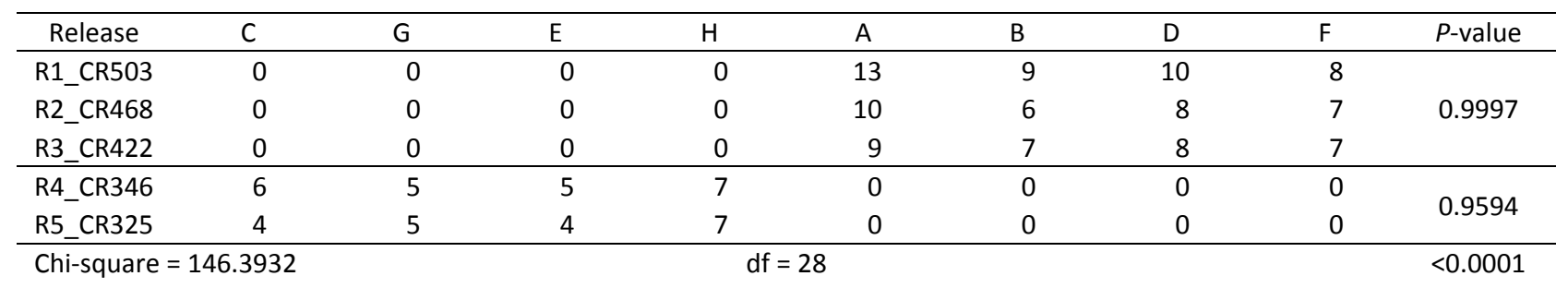

ff. Replicate 32

\begin{tabular}{cccccccccc}
\hline Release & C & G & E & H & A & B & D & F & $P$-value \\
\hline R1_CR503 & 0 & 0 & 0 & 0 & 13 & 9 & 12 & 8 & 7 \\
R2_CR468 & 0 & 0 & 0 & 0 & 9 & 7 & 7 & 0.9981 \\
R3_CR422 & 0 & 0 & 0 & 0 & 9 & 6 & 8 & 7 \\
\hline R4_CR346 & 5 & 5 & 4 & 7 & 0 & 0 & 0 & 0 & 0.9040 \\
R5_CR325 & 6 & 3 & 4 & 7 & 0 & 0 & 0 & 0 & $<0.0001$
\end{tabular}


Table A.4. Estimates of reach survival and cumulative survival for a) yearling Chinook salmon and b) steelhead, along with $P$-values associated with the $F$-tests of homogeneous survival across fish tagged by different staff members.

\section{a. Yearling Chinook salmon}

1) Release 1 (CR503) - Reach survival

\begin{tabular}{|c|c|c|c|c|c|c|c|c|c|c|}
\hline & \multicolumn{2}{|c|}{ Release to CR422.0 } & \multicolumn{2}{|c|}{ CR422.0 to CR349.0 } & \multicolumn{2}{|c|}{ CR349.0 to CR325.0 } & \multicolumn{2}{|c|}{ CR325.0 to CR309.0 } & \multicolumn{2}{|c|}{ CR309.0 to CR234.0 } \\
\hline & Est & $\mathrm{SE}$ & Est & $\mathrm{SE}$ & Est & SE & Est & $\mathrm{SE}$ & Est & $\mathrm{SE}$ \\
\hline$A$ & 0.9111 & 0.0190 & 0.9317 & 0.0176 & 0.9686 & 0.0126 & 0.9784 & 0.0107 & 0.9344 & 0.0185 \\
\hline B & 0.8947 & 0.0249 & 0.9268 & 0.0224 & 0.9600 & 0.0175 & 1.0000 & 0.0000 & 0.9179 & 0.0251 \\
\hline C & 0.9012 & 0.0228 & 0.9484 & 0.0178 & 0.9660 & 0.0150 & 0.9937 & 0.0071 & 0.9098 & 0.0247 \\
\hline D & 0.8994 & 0.0225 & 0.9503 & 0.0171 & 0.9605 & 0.0158 & 1.0000 & 0.0000 & 0.9394 & 0.0199 \\
\hline $\mathrm{E}$ & 0.8571 & 0.0296 & 0.9667 & 0.0164 & 0.9828 & 0.0121 & 0.9831 & 0.0123 & 0.9316 & 0.0247 \\
\hline $\mathrm{F}$ & 0.8968 & 0.0253 & 0.9615 & 0.0170 & 0.9678 & 0.0159 & 0.9917 & 0.0083 & 0.9510 & 0.0199 \\
\hline G & 0.9241 & 0.0220 & 0.9403 & 0.0205 & 0.9762 & 0.0136 & 0.9919 & 0.0081 & 0.9365 & 0.0225 \\
\hline $\mathrm{H}$ & 0.9042 & 0.0190 & 0.9631 & 0.0128 & 0.9809 & 0.0095 & 0.9902 & 0.0069 & 0.9416 & 0.0166 \\
\hline P-value & \multicolumn{2}{|c|}{0.6922} & \multicolumn{2}{|c|}{0.6846} & \multicolumn{2}{|c|}{0.9160} & \multicolumn{2}{|c|}{0.6937} & \multicolumn{2}{|c|}{0.9199} \\
\hline
\end{tabular}

2) Release 1 (CR503) - Cumulative survival

\begin{tabular}{|c|c|c|c|c|c|c|c|c|c|c|}
\hline & \multicolumn{2}{|c|}{ Release to CR422.0 } & \multicolumn{2}{|c|}{ Release to CR349.0 } & \multicolumn{2}{|c|}{ Release to CR325.0 } & \multicolumn{2}{|c|}{ Release to CR309.0 } & \multicolumn{2}{|c|}{ Release to CR234.0 } \\
\hline & Est & $\mathrm{SE}$ & Est & $\mathrm{SE}$ & Est & SE & Est & SE & Est & SE \\
\hline A & 0.9111 & 0.0190 & 0.8489 & 0.0239 & 0.8222 & 0.0255 & 0.8044 & 0.0264 & 0.7517 & 0.0289 \\
\hline B & 0.8947 & 0.0249 & 0.8292 & 0.0306 & 0.7961 & 0.0327 & 0.7961 & 0.0327 & 0.7307 & 0.0360 \\
\hline C & 0.9012 & 0.0228 & 0.8547 & 0.0269 & 0.8256 & 0.0289 & 0.8204 & 0.0293 & 0.7464 & 0.0334 \\
\hline D & 0.8994 & 0.0225 & 0.8547 & 0.0263 & 0.8210 & 0.0287 & 0.8210 & 0.0287 & 0.7712 & 0.0315 \\
\hline E & 0.8571 & 0.0296 & 0.8286 & 0.0319 & 0.8143 & 0.0329 & 0.8006 & 0.0338 & 0.7458 & 0.0371 \\
\hline $\mathrm{F}$ & 0.8968 & 0.0253 & 0.8623 & 0.0286 & 0.8345 & 0.0309 & 0.8276 & 0.0314 & 0.7871 & 0.0341 \\
\hline G & 0.9241 & 0.0220 & 0.8690 & 0.0280 & 0.8483 & 0.0298 & 0.8414 & 0.0303 & 0.7880 & 0.0342 \\
\hline $\mathrm{H}$ & 0.9042 & 0.0190 & 0.8708 & 0.0216 & 0.8542 & 0.0228 & 0.8458 & 0.0233 & 0.7964 & 0.0260 \\
\hline P-value & \multicolumn{2}{|c|}{0.6922} & \multicolumn{2}{|c|}{0.9309} & \multicolumn{2}{|c|}{0.8989} & \multicolumn{2}{|c|}{0.9116} & \multicolumn{2}{|c|}{0.8012} \\
\hline
\end{tabular}


Table A.4. (contd)

3) Release 2 (CR468) - Reach survival

\begin{tabular}{|c|c|c|c|c|c|c|c|c|c|c|}
\hline & \multicolumn{2}{|c|}{ Release to CR422.0 } & \multicolumn{2}{|c|}{ CR422.0 to CR349.0 } & \multicolumn{2}{|c|}{ CR349.0 to CR325.0 } & \multicolumn{2}{|c|}{ CR325.0 to CR309.0 } & \multicolumn{2}{|c|}{ CR309.0 to CR234.0 } \\
\hline & Est & SE & Est & SE & Est & SE & Est & SE & Est & SE \\
\hline$A$ & 0.9066 & 0.0216 & 0.9879 & 0.0085 & 0.9691 & 0.0136 & 0.9809 & 0.0109 & 0.9420 & 0.0189 \\
\hline B & 0.9147 & 0.0246 & 0.9407 & 0.0217 & 0.9369 & 0.0231 & 0.9904 & 0.0096 & 0.9728 & 0.0167 \\
\hline D & 0.9484 & 0.0178 & 0.9456 & 0.0187 & 0.9565 & 0.0174 & 0.9924 & 0.0075 & 0.9084 & 0.0252 \\
\hline$E$ & 0.9262 & 0.0237 & 0.9912 & 0.0088 & 0.9821 & 0.0125 & 1.0000 & 0.0000 & 0.9733 & 0.0155 \\
\hline G & 0.9587 & 0.0181 & 0.9914 & 0.0086 & 0.9826 & 0.0122 & 1.0000 & 0.0000 & 0.9395 & 0.0227 \\
\hline H & 0.9227 & 0.0186 & 0.9895 & 0.0074 & 0.9365 & 0.0177 & 0.9892 & 0.0080 & 0.9257 & 0.0199 \\
\hline P-value & \multicolumn{2}{|c|}{0.6034} & \multicolumn{2}{|c|}{0.0208} & \multicolumn{2}{|c|}{0.1745} & \multicolumn{2}{|c|}{0.8435} & \multicolumn{2}{|c|}{0.3297} \\
\hline
\end{tabular}

4) Release 2 (CR468) -Cumulative survival

\begin{tabular}{|c|c|c|c|c|c|c|c|c|c|c|}
\hline & \multicolumn{2}{|c|}{ Release to CR422.0 } & \multicolumn{2}{|c|}{ Release to CR349.0 } & \multicolumn{2}{|c|}{ Release to CR325.0 } & \multicolumn{2}{|c|}{ Release to CR309.0 } & \multicolumn{2}{|c|}{ Release to CR234.0 } \\
\hline & Est & SE & Est & SE & Est & SE & Est & SE & Est & SE \\
\hline A & 0.9066 & 0.0216 & 0.8956 & 0.0227 & 0.8680 & 0.0251 & 0.8514 & 0.0264 & 0.8020 & 0.0296 \\
\hline B & 0.9147 & 0.0246 & 0.8605 & 0.0305 & 0.8062 & 0.0348 & 0.7985 & 0.0353 & 0.7768 & 0.0369 \\
\hline C & 0.9161 & 0.0223 & 0.8903 & 0.0251 & 0.8582 & 0.0280 & 0.8452 & 0.0291 & 0.7965 & 0.0327 \\
\hline D & 0.9484 & 0.0178 & 0.8968 & 0.0244 & 0.8578 & 0.0281 & 0.8513 & 0.0286 & 0.7733 & 0.0337 \\
\hline $\mathrm{E}$ & 0.9262 & 0.0237 & 0.9180 & 0.0248 & 0.9016 & 0.0270 & 0.9016 & 0.0270 & 0.8775 & 0.0298 \\
\hline H & 0.9227 & 0.0186 & 0.9130 & 0.0196 & 0.8551 & 0.0245 & 0.8458 & 0.0251 & 0.7830 & 0.0287 \\
\hline P-value & \multicolumn{2}{|c|}{0.6034} & \multicolumn{2}{|c|}{0.1751} & \multicolumn{2}{|c|}{0.0140} & \multicolumn{2}{|c|}{0.0077} & \multicolumn{2}{|c|}{0.0353} \\
\hline
\end{tabular}


Table A.4. (contd)

5) Release 3 (CR422) - Reach survival

\begin{tabular}{|c|c|c|c|c|c|c|c|c|}
\hline & \multicolumn{2}{|c|}{ Release to CR349.0 } & \multicolumn{2}{|c|}{ CR349.0 to CR325.0 } & \multicolumn{2}{|c|}{ CR325.0 to CR309.0 } & \multicolumn{2}{|c|}{ CR309.0 to CR234.0 } \\
\hline & Est & SE & Est & SE & Est & SE & Est & SE \\
\hline A & 0.9389 & 0.0179 & 0.9527 & 0.0163 & 1.0000 & 0.0000 & 0.9516 & 0.0172 \\
\hline B & 0.9389 & 0.0209 & 0.9098 & 0.0259 & 0.9910 & 0.0090 & 0.9455 & 0.0217 \\
\hline C & 0.9745 & 0.0126 & 0.9542 & 0.0169 & 1.0000 & 0.0000 & 0.9272 & 0.0220 \\
\hline D & 0.9482 & 0.0179 & 0.9723 & 0.0137 & 0.9929 & 0.0071 & 0.9357 & 0.0207 \\
\hline $\mathrm{E}$ & 0.9397 & 0.0221 & 0.9817 & 0.0129 & 1.0006 & 0.0006 & 0.9443 & 0.0225 \\
\hline H & 0.9317 & 0.0176 & 0.9581 & 0.0145 & 0.9891 & 0.0077 & 0.9415 & 0.0178 \\
\hline P-value & \multicolumn{2}{|c|}{0.7931} & \multicolumn{2}{|c|}{0.1229} & \multicolumn{2}{|c|}{0.0752} & \multicolumn{2}{|c|}{0.6593} \\
\hline
\end{tabular}

6) Release 3 (CR422) - Cumulative survival

\begin{tabular}{|c|c|c|c|c|c|c|c|c|}
\hline & \multicolumn{2}{|c|}{ Release to CR349.0 } & \multicolumn{2}{|c|}{ Release to CR325.0 } & \multicolumn{2}{|c|}{ Release to CR309.0 } & \multicolumn{2}{|c|}{ Release to CR234.0 } \\
\hline & Est & SE & Est & SE & Est & SE & Est & SE \\
\hline A & 0.9389 & 0.0179 & 0.8944 & 0.0229 & 0.8944 & 0.0229 & 0.8512 & 0.0267 \\
\hline C & 0.9745 & 0.0126 & 0.9299 & 0.0204 & 0.9299 & 0.0204 & 0.8622 & 0.0278 \\
\hline D & 0.9482 & 0.0179 & 0.9219 & 0.0217 & 0.9154 & 0.0225 & 0.8565 & 0.0283 \\
\hline $\mathrm{E}$ & 0.9397 & 0.0221 & 0.9224 & 0.0248 & 0.9229 & 0.0249 & 0.8715 & 0.0312 \\
\hline $\mathrm{H}$ & 0.9317 & 0.0176 & 0.8927 & 0.0216 & 0.8829 & 0.0225 & 0.8313 & 0.0264 \\
\hline P-value & \multicolumn{2}{|c|}{0.7931} & \multicolumn{2}{|c|}{0.3975} & \multicolumn{2}{|c|}{0.3121} & \multicolumn{2}{|c|}{0.5294} \\
\hline
\end{tabular}


Table A.4. (contd)

7) Release 4 (CR346) - Reach survival

\begin{tabular}{|c|c|c|c|c|c|c|}
\hline & \multicolumn{2}{|c|}{ Release to CR325.0 } & \multicolumn{2}{|c|}{ CR325.0 to CR309.0 } & \multicolumn{2}{|c|}{ CR309.0 to CR234.0 } \\
\hline & Est & SE & Est & SE & Est & SE \\
\hline A & 0.9935 & 0.0065 & 0.9737 & 0.0130 & 0.9126 & 0.0233 \\
\hline B & 1.0002 & 0.0002 & 0.9820 & 0.0126 & 0.9560 & 0.0199 \\
\hline C & 0.9919 & 0.0080 & 0.9919 & 0.0081 & 0.9705 & 0.0163 \\
\hline D & 1.0000 & 0.0000 & 0.9767 & 0.0133 & 0.9534 & 0.0190 \\
\hline $\mathrm{E}$ & 1.0000 & 0.0000 & 0.9574 & 0.0208 & 0.9558 & 0.0217 \\
\hline H & 1.0000 & 0.0000 & 0.9941 & 0.0059 & 0.9529 & 0.0163 \\
\hline P-value & \multicolumn{2}{|c|}{0.9217} & \multicolumn{2}{|c|}{0.3168} & \multicolumn{2}{|c|}{0.6115} \\
\hline
\end{tabular}

8) Release 4 (CR346) - Cumulative survival

\begin{tabular}{|c|c|c|c|c|c|c|}
\hline & \multicolumn{2}{|c|}{ Release to CR325.0 } & \multicolumn{2}{|c|}{ Release to CR309.0 } & \multicolumn{2}{|c|}{ Release to CR234.0 } \\
\hline & Est & SE & Est & SE & Est & SE \\
\hline A & 0.9935 & 0.0065 & 0.9673 & 0.0144 & 0.8828 & 0.0261 \\
\hline c & 0.9919 & 0.0080 & 0.9839 & 0.0113 & 0.9548 & 0.0194 \\
\hline D & 1.0000 & 0.0000 & 0.9767 & 0.0133 & 0.9312 & 0.0225 \\
\hline $\mathrm{E}$ & 1.0000 & 0.0000 & 0.9574 & 0.0208 & 0.9152 & 0.0288 \\
\hline $\mathrm{H}$ & 1.0000 & 0.0000 & 0.9941 & 0.0059 & 0.9473 & 0.0172 \\
\hline P-value & \multicolumn{2}{|c|}{0.9217} & \multicolumn{2}{|c|}{0.4389} & \multicolumn{2}{|c|}{0.5142} \\
\hline
\end{tabular}


Table A.4. (contd)

9) Release 5 (CR325) - Reach survival

\begin{tabular}{|c|c|c|c|c|}
\hline & \multicolumn{2}{|c|}{ Release to CR309.0 } & \multicolumn{2}{|c|}{ CR309.0 to CR234.0 } \\
\hline & Est & SE & Est & SE \\
\hline$A$ & 0.9932 & 0.0068 & 0.9385 & 0.0201 \\
\hline B & 0.9826 & 0.0122 & 0.9217 & 0.0255 \\
\hline c & 0.9913 & 0.0087 & 0.9744 & 0.0150 \\
\hline $\mathrm{D}$ & 0.9771 & 0.0131 & 0.9551 & 0.0188 \\
\hline $\mathrm{E}$ & 0.9802 & 0.0139 & 0.9192 & 0.0274 \\
\hline $\mathrm{F}$ & 0.9826 & 0.0122 & 0.9207 & 0.0255 \\
\hline G & 0.9804 & 0.0137 & 0.8909 & 0.0313 \\
\hline $\mathrm{H}$ & 0.9941 & 0.0059 & 0.9121 & 0.0219 \\
\hline P-value & \multicolumn{2}{|c|}{0.9313} & \multicolumn{2}{|c|}{0.2886} \\
\hline
\end{tabular}

N

10) Release 5 (CR325) - Cumulative survival

\begin{tabular}{|c|c|c|c|c|}
\hline & \multicolumn{2}{|c|}{ Release to CR309.0 } & \multicolumn{2}{|c|}{ Release to CR234.0 } \\
\hline & Est & SE & Est & SE \\
\hline A & 0.9932 & 0.0068 & 0.9321 & 0.0209 \\
\hline B & 0.9826 & 0.0122 & 0.9057 & 0.0275 \\
\hline D & 0.9771 & 0.0131 & 0.9332 & 0.0222 \\
\hline $\mathrm{E}$ & 0.9802 & 0.0139 & 0.9010 & 0.0297 \\
\hline $\mathrm{F}$ & 0.9826 & 0.0122 & 0.9047 & 0.0274 \\
\hline P-value & \multicolumn{2}{|c|}{0.9313} & \multicolumn{2}{|c|}{0.3072} \\
\hline
\end{tabular}


Table A.4. (contd)

\section{b. Steelhead}

1) Release 1 (CR503) - Reach survival

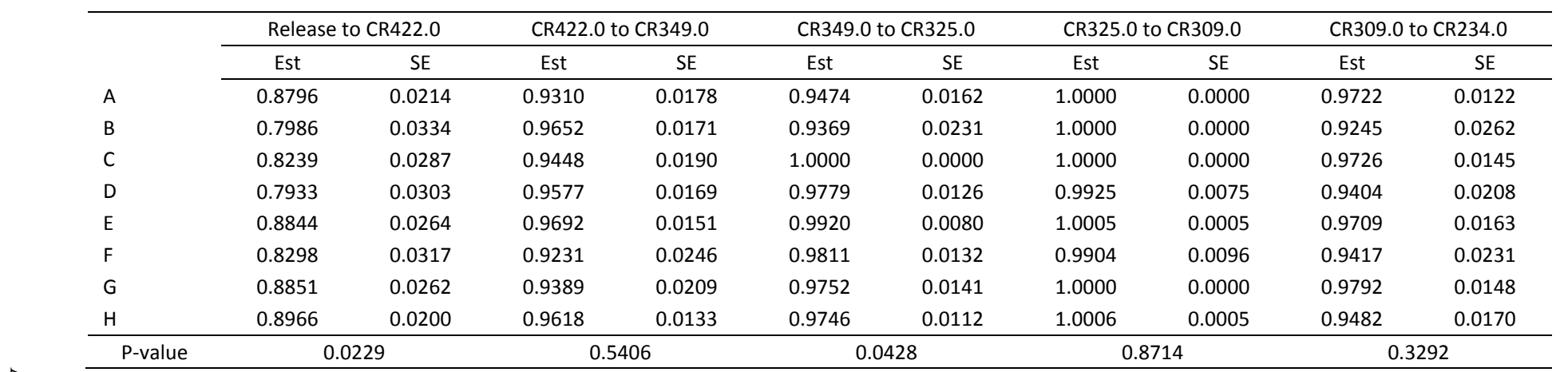

$\stackrel{⿱ 乛}{\mathrm{w}}$

2) Release 1 (CR503) - Cumulative survival

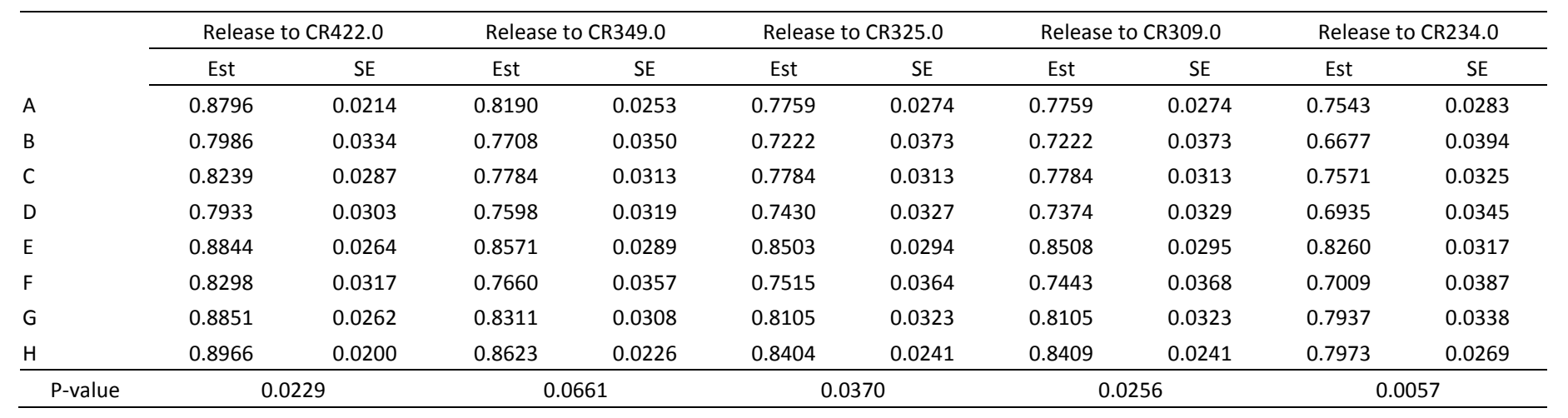


Table A.4. (contd)

3) Release 2 (CR468) - Reach survival

\begin{tabular}{|c|c|c|c|c|c|c|c|c|c|c|}
\hline & \multicolumn{2}{|c|}{ Release to CR422.0 } & \multicolumn{2}{|c|}{ CR422.0 to CR349.0 } & \multicolumn{2}{|c|}{ CR349.0 to CR325.0 } & \multicolumn{2}{|c|}{ CR325.0 to CR309.0 } & \multicolumn{2}{|c|}{ CR309.0 to CR234.0 } \\
\hline & Est & SE & Est & SE & Est & SE & Est & SE & Est & $\mathrm{SE}$ \\
\hline A & 0.9162 & 0.0207 & 0.9451 & 0.0178 & 0.9739 & 0.0129 & 0.9933 & 0.0067 & 0.9688 & 0.0150 \\
\hline B & 0.8828 & 0.0284 & 0.9115 & 0.0267 & 0.9902 & 0.0098 & 1.0000 & 0.0000 & 0.9219 & 0.0269 \\
\hline D & 0.9286 & 0.0208 & 0.9231 & 0.0223 & 0.9847 & 0.0107 & 1.0000 & 0.0000 & 0.9690 & 0.0153 \\
\hline$E$ & 0.8810 & 0.0289 & 0.9640 & 0.0177 & 0.9810 & 0.0133 & 0.9908 & 0.0097 & 0.9536 & 0.0218 \\
\hline $\mathrm{F}$ & 0.9160 & 0.0242 & 0.9417 & 0.0214 & 0.9643 & 0.0175 & 1.0000 & 0.0000 & 0.9820 & 0.0130 \\
\hline $\mathrm{H}$ & 0.9196 & 0.0193 & 0.9290 & 0.0190 & 0.9706 & 0.0130 & 0.9939 & 0.0060 & 0.9417 & 0.0188 \\
\hline P-value & \multicolumn{2}{|c|}{0.5984} & \multicolumn{2}{|c|}{0.7263} & \multicolumn{2}{|c|}{0.4919} & \multicolumn{2}{|c|}{0.8238} & \multicolumn{2}{|c|}{0.2294} \\
\hline
\end{tabular}

4) Release 2 (CR468) - Cumulative survival

\begin{tabular}{|c|c|c|c|c|c|c|c|c|c|c|}
\hline & \multicolumn{2}{|c|}{ Release to CR422.0 } & \multicolumn{2}{|c|}{ Release to CR349.0 } & \multicolumn{2}{|c|}{ Release to CR325.0 } & \multicolumn{2}{|c|}{ Release to CR309.0 } & \multicolumn{2}{|c|}{ Release to CR234.0 } \\
\hline & Est & SE & Est & SE & Est & SE & Est & SE & Est & SE \\
\hline A & 0.9162 & 0.0207 & 0.8659 & 0.0255 & 0.8433 & 0.0272 & 0.8376 & 0.0276 & 0.8115 & 0.0295 \\
\hline B & 0.8828 & 0.0284 & 0.8047 & 0.0350 & 0.7968 & 0.0356 & 0.7968 & 0.0356 & 0.7345 & 0.0392 \\
\hline D & 0.9286 & 0.0208 & 0.8571 & 0.0282 & 0.8441 & 0.0292 & 0.8441 & 0.0292 & 0.8179 & 0.0311 \\
\hline$E$ & 0.8810 & 0.0289 & 0.8492 & 0.0319 & 0.8330 & 0.0333 & 0.8254 & 0.0339 & 0.7871 & 0.0369 \\
\hline $\mathrm{H}$ & 0.9196 & 0.0193 & 0.8543 & 0.0250 & 0.8291 & 0.0267 & 0.8241 & 0.0270 & 0.7761 & 0.0298 \\
\hline P-value & \multicolumn{2}{|c|}{0.5984} & \multicolumn{2}{|c|}{0.8151} & \multicolumn{2}{|c|}{0.9408} & \multicolumn{2}{|c|}{0.9634} & \multicolumn{2}{|c|}{0.5815} \\
\hline
\end{tabular}


Table A.4. (contd)

5) Release 3 (CR422) - Reach survival

\begin{tabular}{|c|c|c|c|c|c|c|c|c|}
\hline & \multicolumn{2}{|c|}{ Release to CR349.0 } & \multicolumn{2}{|c|}{ CR349.0 to CR325.0 } & \multicolumn{2}{|c|}{ CR325.0 to CR309.0 } & \multicolumn{2}{|c|}{ CR309.0 to CR234.0 } \\
\hline & Est & SE & Est & SE & Est & SE & Est & SE \\
\hline A & 0.9266 & 0.0196 & 0.9695 & 0.0134 & 0.9937 & 0.0063 & 0.9624 & 0.0152 \\
\hline B & 0.9291 & 0.0228 & 0.9487 & 0.0204 & 1.0000 & 0.0000 & 0.9647 & 0.0177 \\
\hline D & 0.9359 & 0.0196 & 0.9583 & 0.0167 & 0.9928 & 0.0072 & 0.9799 & 0.0126 \\
\hline E & 0.9496 & 0.0201 & 0.9732 & 0.0153 & 0.9908 & 0.0091 & 0.9630 & 0.0182 \\
\hline $\mathrm{F}$ & 0.9313 & 0.0221 & 0.9664 & 0.0165 & 1.0000 & 0.0000 & 0.9489 & 0.0208 \\
\hline $\mathrm{H}$ & 0.9324 & 0.0175 & 0.9789 & 0.0104 & 0.9839 & 0.0092 & 0.9704 & 0.0133 \\
\hline P-value & \multicolumn{2}{|c|}{0.3370} & \multicolumn{2}{|c|}{0.7138} & \multicolumn{2}{|c|}{0.7856} & \multicolumn{2}{|c|}{0.8674} \\
\hline
\end{tabular}

i v

6) Release 3 (CR422) - Reach survival

\begin{tabular}{|c|c|c|c|c|c|c|c|c|}
\hline & \multicolumn{2}{|c|}{ Release to CR349.0 } & \multicolumn{2}{|c|}{ Release to CR325.0 } & \multicolumn{2}{|c|}{ Release to CR309.0 } & \multicolumn{2}{|c|}{ Release to CR234.0 } \\
\hline & Est & $\mathrm{SE}$ & Est & SE & Est & $\mathrm{SE}$ & Est & $\mathrm{SE}$ \\
\hline$A$ & 0.9266 & 0.0196 & 0.8983 & 0.0227 & 0.8927 & 0.0233 & 0.8591 & 0.0262 \\
\hline B & 0.9291 & 0.0228 & 0.8815 & 0.0287 & 0.8815 & 0.0287 & 0.8504 & 0.0318 \\
\hline D & 0.9359 & 0.0196 & 0.8969 & 0.0244 & 0.8904 & 0.0251 & 0.8725 & 0.0270 \\
\hline E & 0.9496 & 0.0201 & 0.9241 & 0.0243 & 0.9157 & 0.0255 & 0.8818 & 0.0297 \\
\hline $\mathrm{H}$ & 0.9324 & 0.0175 & 0.9127 & 0.0197 & 0.8980 & 0.0211 & 0.8715 & 0.0237 \\
\hline P-value & \multicolumn{2}{|c|}{0.3370} & \multicolumn{2}{|c|}{0.1350} & \multicolumn{2}{|c|}{0.3479} & \multicolumn{2}{|c|}{0.8434} \\
\hline
\end{tabular}


Table A.4. (contd)

7) Release 4 (CR346) - Reach survival

\begin{tabular}{|c|c|c|c|c|c|c|}
\hline & \multicolumn{2}{|c|}{ Release to CR325.0 } & \multicolumn{2}{|c|}{ CR325.0 to CR309.0 } & \multicolumn{2}{|c|}{ CR309.0 to CR234.0 } \\
\hline & Est & SE & Est & SE & Est & SE \\
\hline A & 0.9936 & 0.0063 & 0.9936 & 0.0064 & 0.9742 & 0.0127 \\
\hline B & 1.0000 & 0.0000 & 1.0000 & 0.0000 & 0.9639 & 0.0179 \\
\hline D & 0.9535 & 0.0185 & 0.9919 & 0.0081 & 0.9597 & 0.0180 \\
\hline E & 1.0000 & 0.0000 & 1.0009 & 0.0008 & 0.9589 & 0.0209 \\
\hline $\mathrm{F}$ & 0.9825 & 0.0123 & 0.9911 & 0.0089 & 0.9657 & 0.0178 \\
\hline $\mathrm{H}$ & 0.9939 & 0.0061 & 0.9816 & 0.0105 & 0.9693 & 0.0138 \\
\hline P-value & \multicolumn{2}{|c|}{0.0947} & \multicolumn{2}{|c|}{0.4834} & \multicolumn{2}{|c|}{0.8119} \\
\hline
\end{tabular}

i

8) Release 4 (CR346) - Cumulative survival

\begin{tabular}{|c|c|c|c|c|c|c|}
\hline & \multicolumn{2}{|c|}{ Release to CR325.0 } & \multicolumn{2}{|c|}{ Release to CR309.0 } & \multicolumn{2}{|c|}{ Release to CR234.0 } \\
\hline & Est & SE & Est & SE & Est & SE \\
\hline A & 0.9936 & 0.0063 & 0.9873 & 0.0090 & 0.9618 & 0.0153 \\
\hline B & 1.0000 & 0.0000 & 1.0000 & 0.0000 & 0.9639 & 0.0179 \\
\hline D & 0.9535 & 0.0185 & 0.9457 & 0.0199 & 0.9076 & 0.0256 \\
\hline $\mathrm{E}$ & 1.0000 & 0.0000 & 1.0009 & 0.0008 & 0.9598 & 0.0205 \\
\hline $\mathrm{F}$ & 0.9825 & 0.0123 & 0.9737 & 0.0150 & 0.9402 & 0.0226 \\
\hline $\mathrm{H}$ & 0.9939 & 0.0061 & 0.9756 & 0.0120 & 0.9456 & 0.0178 \\
\hline P-value & \multicolumn{2}{|c|}{0.0947} & \multicolumn{2}{|c|}{0.0512} & \multicolumn{2}{|c|}{0.3512} \\
\hline
\end{tabular}


Table A.4. (contd)

9) Release 5 (CR325) - Reach survival

\begin{tabular}{|c|c|c|c|c|}
\hline & \multicolumn{2}{|c|}{ Release to CR309.0 } & \multicolumn{2}{|c|}{ CR309.0 to CR234.0 } \\
\hline & Est & SE & Est & SE \\
\hline A & 0.9879 & 0.0088 & 0.9471 & 0.0188 \\
\hline B & 1.0000 & 0.0000 & 0.9458 & 0.0221 \\
\hline D & 0.9688 & 0.0154 & 0.9362 & 0.0221 \\
\hline$E$ & 1.0000 & 0.0000 & 0.9204 & 0.0278 \\
\hline $\mathrm{F}$ & 0.9655 & 0.0169 & 0.9470 & 0.0213 \\
\hline $\mathrm{H}$ & 0.9447 & 0.0180 & 0.9555 & 0.0171 \\
\hline P-value & \multicolumn{2}{|c|}{0.0688} & \multicolumn{2}{|c|}{0.9297} \\
\hline
\end{tabular}

10) Release 5 (CR325) - Cumulative survival

\begin{tabular}{|c|c|c|c|c|}
\hline & \multicolumn{2}{|c|}{ Release to CR309.0 } & \multicolumn{2}{|c|}{ Release to CR234.0 } \\
\hline & Est & SE & Est & SE \\
\hline A & 0.9879 & 0.0088 & 0.9357 & 0.0202 \\
\hline B & 1.0000 & 0.0000 & 0.9458 & 0.0221 \\
\hline D & 0.9688 & 0.0154 & 0.9070 & 0.0258 \\
\hline $\mathrm{E}$ & 1.0000 & 0.0000 & 0.9204 & 0.0278 \\
\hline $\mathrm{F}$ & 0.9655 & 0.0169 & 0.9143 & 0.0261 \\
\hline $\mathrm{H}$ & 0.9447 & 0.0180 & 0.9027 & 0.0235 \\
\hline P-value & \multicolumn{2}{|c|}{0.0688} & \multicolumn{2}{|c|}{0.7495} \\
\hline
\end{tabular}




\section{A.1.2 Summer Study}

Data from all nine release locations in the four-dam study were examined for tagger effects. This was again done to maximize the statistical power to detect tagger effects that might have influenced any of the Lower Columbia River survival studies in summer 2012.

Tagger effort was balanced across the nine release locations and eight taggers (Table A.5) $\left(P\left(\chi_{56}^{2} \geq 4.8194\right)=1\right)$. Tagger effort was also examined within each of the 32 replicate releases (Table A.6). Tagger effort was found to be balanced within the individual project releases (i.e., $R_{1}-R_{3}, R_{4}-R_{5}, R_{6}-R_{7}$, and $R_{8}-R_{9}$ ) within each of the replicate releases (Table A.7). These conditionally balanced designs within the individual replicates and the balance of taggers across projects resulted in the overall balanced design.

Tests of tagger effects were examined across the nine release locations based on both reach survivals and cumulative reach survivals (Table A.7). Five of the 45 tests of homogeneous reach survival across taggers were significant at $\alpha=0.10$ (i.e., 11.11\%). Two of the 44 tests of homogeneous cumulative reach survival across taggers were significant at $\alpha=0.10$ (i.e., $4.55 \%$ ). The rate of rejection in both cases is below that expected by chance alone, suggesting no evidence of tagger effects.

Based on the balanced release design (Table A.5 and Table A.6) and tests of homogeneity (Table A.7), all fish tagged by all staff members were used in the subsequent survival analyses for summer 2012. 
Table A.5. Numbers of subyearling Chinook salmon tagged by each staff member by release location (i.e., $\left.R_{1}, R_{2}, \ldots\right)$. Chi-square test of homogeneity was not significant $\left(P\left(\chi_{56}^{2} \geq 4.8194\right)=1\right)$.

\begin{tabular}{crrrrrrrc}
\hline & \multicolumn{10}{c}{ Tagger } \\
\cline { 2 - 9 } Release location & \multicolumn{1}{c}{$\mathrm{E}$} & $\mathrm{C}$ & $\mathrm{H}$ & $\mathrm{G}$ & $\mathrm{B}$ & \multicolumn{1}{c}{$\mathrm{D}$} & $\mathrm{F}$ & $\mathrm{A}$ \\
\hline R1_CR503 & 255 & 327 & 397 & 287 & 309 & 304 & 287 & 358 \\
R2_CR468 & 201 & 246 & 316 & 224 & 239 & 248 & 235 & 284 \\
R3_CR422 & 192 & 255 & 314 & 218 & 239 & 241 & 236 & 289 \\
R4_CR346 & 98 & 126 & 153 & 111 & 119 & 119 & 116 & 144 \\
R5_CR325 & 93 & 123 & 157 & 114 & 119 & 122 & 111 & 144 \\
R6_CR307 & 81 & 105 & 124 & 90 & 91 & 94 & 89 & 114 \\
R7_CR275 & 78 & 103 & 127 & 90 & 88 & 101 & 90 & 109 \\
R8_CR233 & 203 & 260 & 315 & 225 & 235 & 241 & 227 & 288 \\
R9_CR156 & 199 & 263 & 312 & 232 & 229 & 242 & 233 & 285 \\
\hline Chi-square $=4.8194$ & & & & df =56 & & & & P-value $=1$
\end{tabular}


Table A.6. Contingency tables with numbers of subyearling Chinook salmon tagged by each staff member per release location within a replicate release. A total of 32 replicate day or night releases were performed over the course of the summer 2012 study. Results of chi-square tests of homogeneity presented in the form of $P$-values.

a. Replicate 1

\begin{tabular}{|c|c|c|c|c|c|c|c|c|c|}
\hline Release & $E$ & $C$ & $\mathrm{H}$ & $\mathrm{G}$ & $B$ & $\mathrm{D}$ & $\mathrm{F}$ & A & P-value \\
\hline R1_CR503 & 16 & 20 & 25 & 17 & 0 & 0 & 0 & 0 & \multirow{3}{*}{0.9992} \\
\hline R2_CR468 & 13 & 16 & 21 & 13 & 0 & 0 & 0 & 0 & \\
\hline R3_CR422 & 12 & 15 & 23 & 13 & 0 & 0 & 0 & 0 & \\
\hline R4_CR346 & 0 & 0 & 0 & 0 & 8 & 7 & 8 & 8 & \multirow{2}{*}{0.9876} \\
\hline R5_CR325 & 0 & 0 & 0 & 0 & 8 & 8 & 7 & 8 & \\
\hline R6_CR307 & 0 & 0 & 0 & 0 & 6 & 5 & 6 & 8 & \multirow{2}{*}{0.9841} \\
\hline R7_CR275 & 0 & 0 & 0 & 0 & 6 & 6 & 6 & 7 & \\
\hline R8_CR233 & 0 & 0 & 0 & 0 & 15 & 14 & 15 & 19 & \multirow{2}{*}{0.9824} \\
\hline R9_CR156 & 0 & 0 & 0 & 0 & 13 & 15 & 15 & 19 & \\
\hline
\end{tabular}

b. Replicate 2

\begin{tabular}{|c|c|c|c|c|c|c|c|c|c|}
\hline Release & $E$ & $\mathrm{C}$ & $\mathrm{H}$ & $\mathrm{G}$ & $B$ & $\mathrm{D}$ & $\mathrm{F}$ & $A$ & P-value \\
\hline R1_CR503 & 16 & 19 & 27 & 17 & 0 & 0 & 0 & 0 & \multirow{3}{*}{1} \\
\hline R2_CR468 & 13 & 15 & 21 & 14 & 0 & 0 & 0 & 0 & \\
\hline R3_CR422 & 12 & 16 & 21 & 14 & 0 & 0 & 0 & 0 & \\
\hline R4_CR346 & 0 & 0 & 0 & 0 & 9 & 7 & 9 & 10 & \multirow{2}{*}{0.9886} \\
\hline R5_CR325 & 0 & 0 & 0 & 0 & 8 & 8 & 9 & 10 & \\
\hline R6_CR307 & 0 & 0 & 0 & 0 & 6 & 5 & 6 & 8 & \multirow{2}{*}{0.9841} \\
\hline R7_CR275 & 0 & 0 & 0 & 0 & 6 & 6 & 6 & 7 & \\
\hline R8_CR233 & 12 & 16 & 21 & 14 & 0 & 0 & 0 & 0 & \multirow{2}{*}{0.9967} \\
\hline R9_CR156 & 12 & 17 & 20 & 14 & 0 & 0 & 0 & 0 & \\
\hline
\end{tabular}

c. Replicate 3

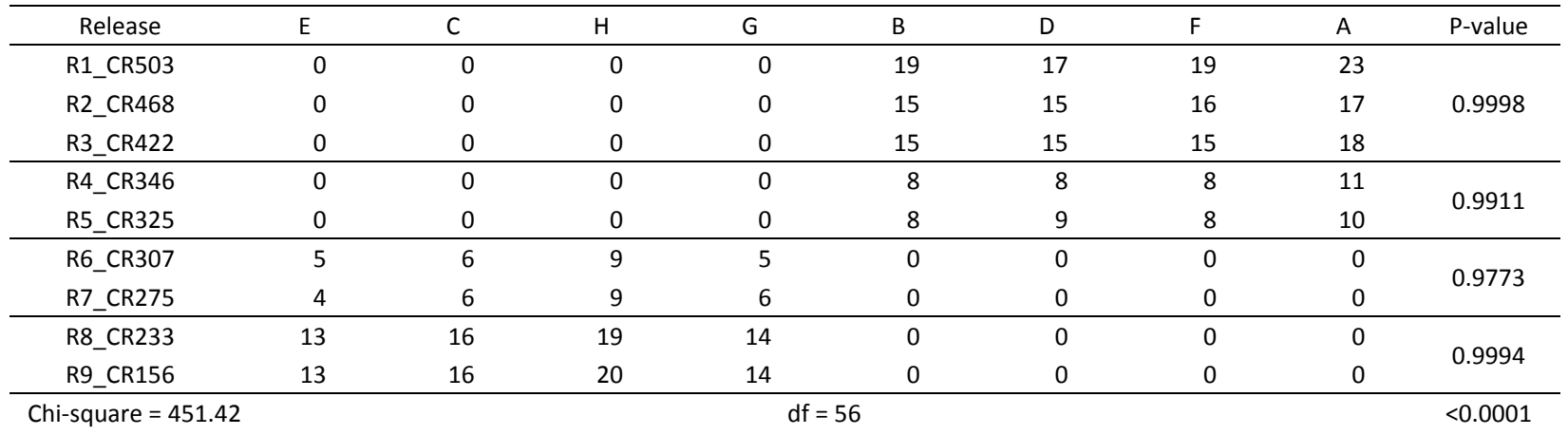


Table A.6. (contd)

d. Replicate 4

\begin{tabular}{|c|c|c|c|c|c|c|c|c|c|}
\hline Release & $E$ & $C$ & $\mathrm{H}$ & G & B & $\mathrm{D}$ & $\mathrm{F}$ & $A$ & P-value \\
\hline R1_CR503 & 0 & 0 & 0 & 0 & 21 & 18 & 19 & 21 & \multirow{3}{*}{0.9884} \\
\hline R2_CR468 & 0 & 0 & 0 & 0 & 13 & 16 & 16 & 18 & \\
\hline R3_CR422 & 0 & 0 & 0 & 0 & 15 & 13 & 16 & 18 & \\
\hline R4_CR346 & 6 & 8 & 10 & 7 & 0 & 0 & 0 & 0 & \multirow{2}{*}{0.9929} \\
\hline R5_CR325 & 5 & 7 & 10 & 7 & 0 & 0 & 0 & 0 & \\
\hline R6_CR307 & 5 & 6 & 8 & 6 & 0 & 0 & 0 & 0 & \multirow{2}{*}{1} \\
\hline R7_CR275 & 5 & 6 & 8 & 6 & 0 & 0 & 0 & 0 & \\
\hline R8_CR233 & 12 & 15 & 22 & 14 & 0 & 0 & 0 & 0 & \multirow{2}{*}{0.8004} \\
\hline R9_CR156 & 13 & 16 & 17 & 17 & 0 & 0 & 0 & 0 & \\
\hline
\end{tabular}

e. Replicate 5

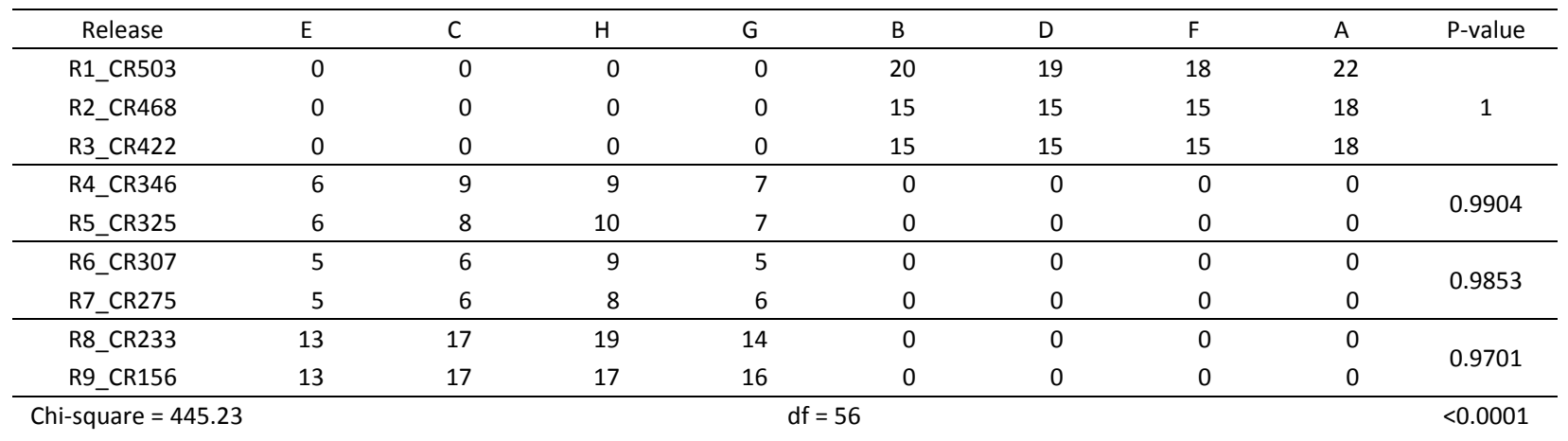

f. Replicate 6

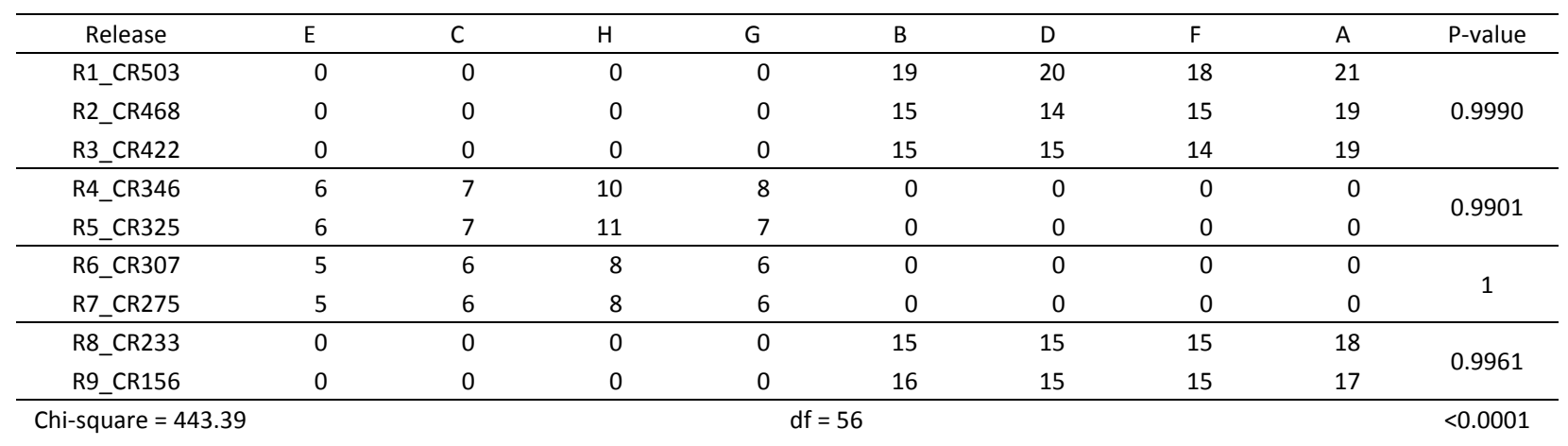


Table A.6. (contd)

g. $\quad$ Replicate 7

\begin{tabular}{|c|c|c|c|c|c|c|c|c|c|}
\hline Release & $\mathrm{E}$ & $C$ & $\mathrm{H}$ & $\mathrm{G}$ & B & D & $\mathrm{F}$ & $A$ & P-value \\
\hline R1_CR503 & 15 & 18 & 26 & 16 & 0 & 0 & 0 & 0 & \multirow{3}{*}{1} \\
\hline R2_CR468 & 13 & 14 & 22 & 14 & 0 & 0 & 0 & 0 & \\
\hline R3_CR422 & 13 & 14 & 22 & 14 & 0 & 0 & 0 & 0 & \\
\hline R4_CR346 & 6 & 8 & 10 & 7 & 0 & 0 & 0 & 0 & \multirow{2}{*}{0.9416} \\
\hline R5_CR325 & 5 & 8 & 9 & 9 & 0 & 0 & 0 & 0 & \\
\hline R6_CR307 & 0 & 0 & 0 & 0 & 6 & 6 & 6 & 7 & \multirow{2}{*}{1} \\
\hline R7_CR275 & 0 & 0 & 0 & 0 & 6 & 6 & 6 & 7 & \\
\hline R8_CR233 & 0 & 0 & 0 & 0 & 15 & 15 & 14 & 18 & \multirow{2}{*}{0.9932} \\
\hline R9_CR156 & 0 & 0 & 0 & 0 & 15 & 14 & 15 & 19 & \\
\hline
\end{tabular}

h. Replicate 8

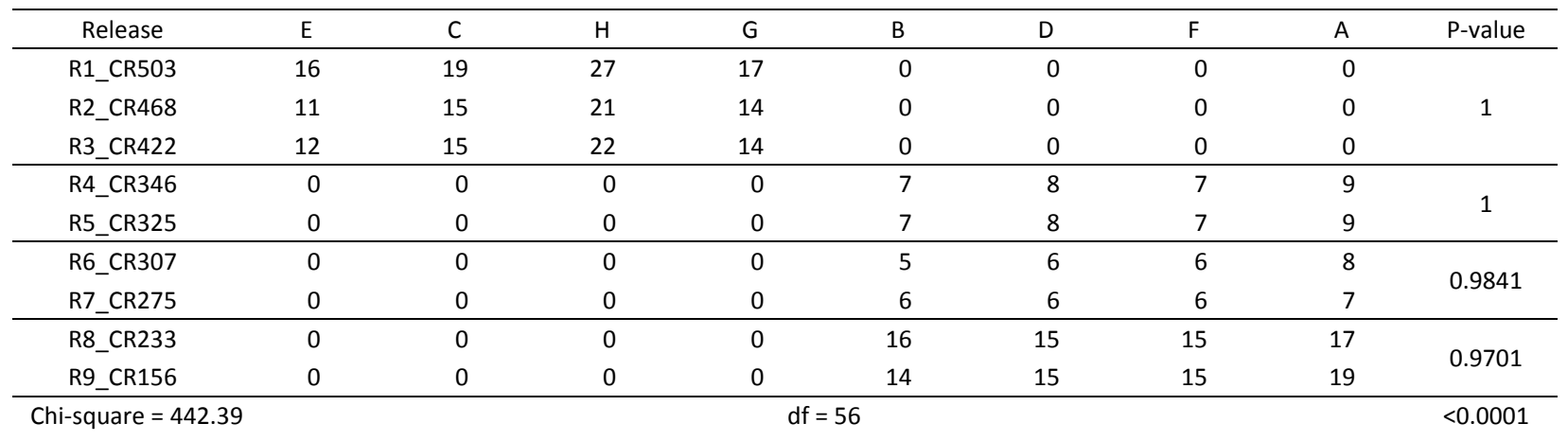

i. Replicate 9

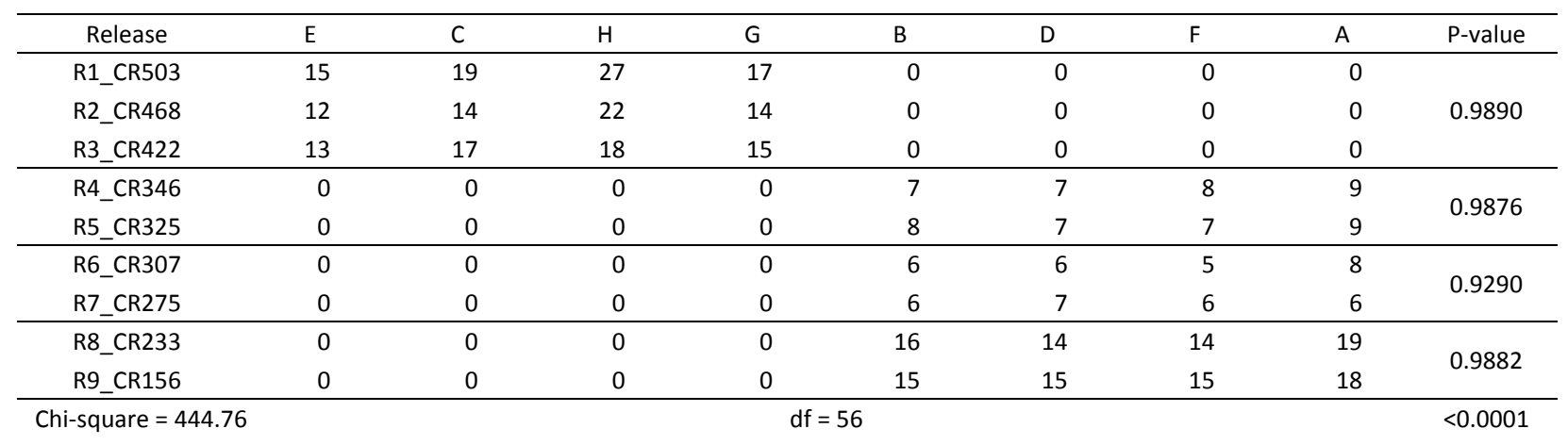


Table A.6. (contd)

j. Replicate 10

\begin{tabular}{|c|c|c|c|c|c|c|c|c|c|}
\hline Release & $\mathrm{E}$ & C & $\mathrm{H}$ & G & B & $\mathrm{D}$ & $\mathrm{F}$ & A & P-value \\
\hline R1_CR503 & 16 & 19 & 26 & 18 & 0 & 0 & 0 & 0 & \multirow{3}{*}{0.9893} \\
\hline R2_CR468 & 12 & 16 & 21 & 12 & 0 & 0 & 0 & 0 & \\
\hline R3_CR422 & 13 & 16 & 18 & 16 & 0 & 0 & 0 & 0 & \\
\hline R4_CR346 & 0 & 0 & 0 & 0 & 7 & 7 & 7 & 10 & \multirow{2}{*}{0.9894} \\
\hline R5_CR325 & 0 & 0 & 0 & 0 & 8 & 7 & 7 & 9 & \\
\hline R6_CR307 & 0 & 0 & 0 & 0 & 6 & 7 & 5 & 7 & \multirow{2}{*}{0.9826} \\
\hline R7_CR275 & 0 & 0 & 0 & 0 & 6 & 6 & 6 & 7 & \\
\hline R8_CR233 & 13 & 16 & 18 & 15 & 0 & 0 & 0 & 0 & \multirow{2}{*}{0.9288} \\
\hline R9_CR156 & 11 & 17 & 21 & 14 & 0 & 0 & 0 & 0 & \\
\hline
\end{tabular}

k. Replicate 11

\begin{tabular}{|c|c|c|c|c|c|c|c|c|c|}
\hline Release & $E$ & $C$ & $\mathrm{H}$ & G & $\mathrm{B}$ & $\mathrm{D}$ & $\mathrm{F}$ & A & P-value \\
\hline R1_CR503 & 0 & 0 & 0 & 0 & 19 & 18 & 18 & 23 & \multirow{3}{*}{0.9980} \\
\hline R2_CR468 & 0 & 0 & 0 & 0 & 14 & 16 & 15 & 18 & \\
\hline R3_CR422 & 0 & 0 & 0 & 0 & 15 & 13 & 16 & 19 & \\
\hline R4_CR346 & 0 & 0 & 0 & 0 & 8 & 7 & 7 & 9 & \multirow{2}{*}{0.9886} \\
\hline R5_CR325 & 0 & 0 & 0 & 0 & 8 & 7 & 8 & 8 & \\
\hline R6_CR307 & 6 & 7 & 7 & 5 & 0 & 0 & 0 & 0 & \multirow{2}{*}{0.9552} \\
\hline R7_CR275 & 5 & 6 & 8 & 6 & 0 & 0 & 0 & 0 & \\
\hline R8_CR233 & 13 & 16 & 19 & 14 & 0 & 0 & 0 & 0 & \multirow{2}{*}{0.9936} \\
\hline R9_CR156 & 13 & 15 & 20 & 15 & 0 & 0 & 0 & 0 & \\
\hline
\end{tabular}

1. Replicate 12

\begin{tabular}{|c|c|c|c|c|c|c|c|c|c|}
\hline Release & $E$ & $\mathrm{C}$ & $\mathrm{H}$ & $G$ & $B$ & $\mathrm{D}$ & $\mathrm{F}$ & $A$ & P-value \\
\hline R1_CR503 & 0 & 0 & 0 & 0 & 19 & 19 & 17 & 23 & \multirow{3}{*}{0.9994} \\
\hline R2_CR468 & 0 & 0 & 0 & 0 & 13 & 15 & 15 & 19 & \\
\hline R3_CR422 & 0 & 0 & 0 & 0 & 14 & 15 & 15 & 18 & \\
\hline R4_CR346 & 6 & 8 & 10 & 7 & 0 & 0 & 0 & 0 & \multirow{2}{*}{0.9881} \\
\hline R5_CR325 & 7 & 8 & 9 & 7 & 0 & 0 & 0 & 0 & \\
\hline R6_CR307 & 5 & 7 & 8 & 5 & 0 & 0 & 0 & 0 & \multirow{2}{*}{1} \\
\hline R7_CR275 & 5 & 7 & 8 & 5 & 0 & 0 & 0 & 0 & \\
\hline R8_CR233 & 13 & 15 & 20 & 14 & 0 & 0 & 0 & 0 & \multirow{2}{*}{0.9548} \\
\hline R9_CR156 & 13 & 18 & 19 & 13 & 0 & 0 & 0 & 0 & \\
\hline
\end{tabular}


Table A.6. (contd)

m. Replicate 13

\begin{tabular}{|c|c|c|c|c|c|c|c|c|c|}
\hline Release & $E$ & $C$ & $\mathrm{H}$ & G & B & $\mathrm{D}$ & $\mathrm{F}$ & $A$ & P-value \\
\hline R1_CR503 & 0 & 0 & 0 & 0 & 20 & 18 & 18 & 23 & \multirow{3}{*}{1} \\
\hline R2_CR468 & 0 & 0 & 0 & 0 & 16 & 15 & 14 & 18 & \\
\hline R3_CR422 & 0 & 0 & 0 & 0 & 16 & 14 & 15 & 18 & \\
\hline R4_CR346 & 6 & 8 & 10 & 7 & 0 & 0 & 0 & 0 & \multirow{2}{*}{1} \\
\hline R5_CR325 & 6 & 8 & 10 & 7 & 0 & 0 & 0 & 0 & \\
\hline R6_CR307 & 5 & 7 & 7 & 6 & 0 & 0 & 0 & 0 & \multirow{2}{*}{0.9841} \\
\hline R7_CR275 & 5 & 7 & 8 & 5 & 0 & 0 & 0 & 0 & \\
\hline R8_CR233 & 13 & 18 & 19 & 13 & 0 & 0 & 0 & 0 & \multirow{2}{*}{0.9967} \\
\hline R9_CR156 & 13 & 19 & 18 & 13 & 0 & 0 & 0 & 0 & \\
\hline
\end{tabular}

n. Replicate 14

\begin{tabular}{|c|c|c|c|c|c|c|c|c|c|}
\hline Release & $E$ & $C$ & $\mathrm{H}$ & G & B & $\mathrm{D}$ & $\mathrm{F}$ & A & P-value \\
\hline R1_CR503 & 0 & 0 & 0 & 0 & 19 & 18 & 19 & 23 & \multirow{3}{*}{0.9992} \\
\hline R2_CR468 & 0 & 0 & 0 & 0 & 16 & 15 & 14 & 18 & \\
\hline R3_CR422 & 0 & 0 & 0 & 0 & 15 & 16 & 13 & 19 & \\
\hline R4_CR346 & 6 & 8 & 10 & 7 & 0 & 0 & 0 & 0 & \multirow{2}{*}{1} \\
\hline R5_CR325 & 6 & 8 & 10 & 7 & 0 & 0 & 0 & 0 & \\
\hline R6_CR307 & 5 & 8 & 8 & 4 & 0 & 0 & 0 & 0 & \multirow{2}{*}{0.9974} \\
\hline R7_CR275 & 5 & 7 & 8 & 4 & 0 & 0 & 0 & 0 & \\
\hline R8_CR233 & 0 & 0 & 0 & 0 & 15 & 15 & 15 & 18 & \multirow{2}{*}{0.9955} \\
\hline R9_CR156 & 0 & 0 & 0 & 0 & 14 & 15 & 16 & 18 & \\
\hline
\end{tabular}

o. Replicate 15

\begin{tabular}{|c|c|c|c|c|c|c|c|c|c|}
\hline Release & $\mathrm{E}$ & C & $\mathrm{H}$ & G & $B$ & $\mathrm{D}$ & $\mathrm{F}$ & A & P-value \\
\hline R1_CR503 & 16 & 21 & 23 & 19 & 0 & 0 & 0 & 0 & \multirow{3}{*}{0.9967} \\
\hline R2_CR468 & 13 & 17 & 17 & 16 & 0 & 0 & 0 & 0 & \\
\hline R3_CR422 & 13 & 17 & 20 & 13 & 0 & 0 & 0 & 0 & \\
\hline R4_CR346 & 6 & 8 & 10 & 7 & 0 & 0 & 0 & 0 & \multirow{2}{*}{0.9853} \\
\hline R5_CR325 & 5 & 9 & 10 & 7 & 0 & 0 & 0 & 0 & \\
\hline R6_CR307 & 0 & 0 & 0 & 0 & 6 & 6 & 6 & 7 & \multirow{2}{*}{0.9826} \\
\hline R7_CR275 & 0 & 0 & 0 & 0 & 6 & 7 & 5 & 7 & \\
\hline R8_CR233 & 0 & 0 & 0 & 0 & 15 & 15 & 15 & 18 & \multirow{2}{*}{1} \\
\hline R9_CR156 & 0 & 0 & 0 & 0 & 15 & 15 & 15 & 18 & \\
\hline
\end{tabular}


Table A.6. (contd)

p. Replicate 16

\begin{tabular}{|c|c|c|c|c|c|c|c|c|c|}
\hline Release & $\mathrm{E}$ & C & $\mathrm{H}$ & G & $\mathrm{B}$ & $\mathrm{D}$ & $\mathrm{F}$ & A & P-value \\
\hline R1_CR503 & 16 & 21 & 23 & 19 & 0 & 0 & 0 & 0 & \multirow{3}{*}{0.9946} \\
\hline R2_CR468 & 13 & 16 & 19 & 15 & 0 & 0 & 0 & 0 & \\
\hline R3_CR422 & 11 & 16 & 22 & 14 & 0 & 0 & 0 & 0 & \\
\hline R4_CR346 & 0 & 0 & 0 & 0 & 7 & 8 & 7 & 9 & \multirow{2}{*}{0.9876} \\
\hline R5_CR325 & 0 & 0 & 0 & 0 & 8 & 7 & 7 & 9 & \\
\hline R6_CR307 & 0 & 0 & 0 & 0 & 6 & 6 & 6 & 7 & \multirow{2}{*}{0.9826} \\
\hline R7_CR275 & 0 & 0 & 0 & 0 & 5 & 7 & 6 & 7 & \\
\hline R8_CR233 & 0 & 0 & 0 & 0 & 14 & 16 & 14 & 19 & \multirow{2}{*}{0.9960} \\
\hline R9_CR156 & 0 & 0 & 0 & 0 & 15 & 16 & 14 & 18 & \\
\hline
\end{tabular}

q. Replicate 17

\begin{tabular}{|c|c|c|c|c|c|c|c|c|c|}
\hline Release & $E$ & C & $\mathrm{H}$ & $\mathrm{G}$ & $\mathrm{B}$ & $\mathrm{D}$ & $\mathrm{F}$ & A & P-value \\
\hline R1_CR503 & 16 & 22 & 20 & 20 & 0 & 0 & 0 & 0 & \multirow{3}{*}{0.9852} \\
\hline R2_CR468 & 13 & 16 & 17 & 15 & 0 & 0 & 0 & 0 & \\
\hline R3_CR422 & 12 & 18 & 20 & 13 & 0 & 0 & 0 & 0 & \\
\hline R4_CR346 & 0 & 0 & 0 & 0 & 8 & 8 & 7 & 8 & \multirow{2}{*}{0.9876} \\
\hline R5_CR325 & 0 & 0 & 0 & 0 & 7 & 8 & 8 & 8 & \\
\hline R6_CR307 & 0 & 0 & 0 & 0 & 6 & 6 & 6 & 7 & \multirow{2}{*}{0.9826} \\
\hline R7_CR275 & 0 & 0 & 0 & 0 & 6 & 7 & 5 & 7 & \\
\hline R8_CR233 & 0 & 0 & 0 & 0 & 15 & 16 & 13 & 19 & \multirow{2}{*}{0.9772} \\
\hline R9_CR156 & 0 & 0 & 0 & 0 & 15 & 15 & 15 & 18 & \\
\hline
\end{tabular}

r. Replicate 18

\begin{tabular}{|c|c|c|c|c|c|c|c|c|c|}
\hline Release & $E$ & $\mathrm{C}$ & $\mathrm{H}$ & $G$ & $B$ & $\mathrm{D}$ & $\mathrm{F}$ & $A$ & P-value \\
\hline R1_CR503 & 16 & 20 & 24 & 19 & 0 & 0 & 0 & 0 & \multirow{3}{*}{0.9962} \\
\hline R2_CR468 & 13 & 15 & 21 & 14 & 0 & 0 & 0 & 0 & \\
\hline R3_CR422 & 13 & 18 & 19 & 13 & 0 & 0 & 0 & 0 & \\
\hline R4_CR346 & 0 & 0 & 0 & 0 & 7 & 8 & 7 & 9 & \multirow{2}{*}{0.9894} \\
\hline R5_CR325 & 0 & 0 & 0 & 0 & 7 & 7 & 7 & 10 & \\
\hline R6_CR307 & 0 & 0 & 0 & 0 & 6 & 6 & 6 & 7 & \multirow{2}{*}{0.9841} \\
\hline R7_CR275 & 0 & 0 & 0 & 0 & 5 & 6 & 6 & 8 & \\
\hline R8_CR233 & 12 & 16 & 19 & 15 & 0 & 0 & 0 & 0 & \multirow{2}{*}{0.9725} \\
\hline R9_CR156 & 13 & 17 & 20 & 13 & 0 & 0 & 0 & 0 & \\
\hline
\end{tabular}


Table A.6. (contd)

S. Replicate 19

\begin{tabular}{|c|c|c|c|c|c|c|c|c|c|}
\hline Release & $\mathrm{E}$ & $\mathrm{C}$ & $\mathrm{H}$ & G & $\mathrm{B}$ & $\mathrm{D}$ & $\mathrm{F}$ & A & P-value \\
\hline R1_CR503 & 0 & 0 & 0 & 0 & 19 & 19 & 19 & 22 & \multirow{3}{*}{0.9997} \\
\hline R2_CR468 & 0 & 0 & 0 & 0 & 16 & 16 & 14 & 16 & \\
\hline R3_CR422 & 0 & 0 & 0 & 0 & 15 & 15 & 15 & 18 & \\
\hline R4_CR346 & 0 & 0 & 0 & 0 & 8 & 7 & 7 & 9 & \multirow{2}{*}{0.9669} \\
\hline R5_CR325 & 0 & 0 & 0 & 0 & 7 & 8 & 6 & 10 & \\
\hline R6_CR307 & 5 & 7 & 7 & 6 & 0 & 0 & 0 & 0 & \multirow{2}{*}{0.9861} \\
\hline R7_CR275 & 5 & 6 & 8 & 6 & 0 & 0 & 0 & 0 & \\
\hline R8_CR233 & 13 & 16 & 21 & 13 & 0 & 0 & 0 & 0 & \multirow{2}{*}{0.9951} \\
\hline R9_CR156 & 12 & 17 & 21 & 13 & 0 & 0 & 0 & 0 & \\
\hline
\end{tabular}

t. Replicate 20

\begin{tabular}{|c|c|c|c|c|c|c|c|c|c|}
\hline Release & $E$ & $C$ & $\mathrm{H}$ & $\mathrm{G}$ & $B$ & $\mathrm{D}$ & $\mathrm{F}$ & $\mathrm{A}$ & P-value \\
\hline R1_CR503 & 0 & 0 & 0 & 0 & 19 & 19 & 18 & 22 & \multirow{3}{*}{1} \\
\hline R2_CR468 & 0 & 0 & 0 & 0 & 16 & 15 & 14 & 18 & \\
\hline R3_CR422 & 0 & 0 & 0 & 0 & 15 & 15 & 15 & 18 & \\
\hline R4_CR346 & 6 & 8 & 10 & 7 & 0 & 0 & 0 & 0 & \multirow{2}{*}{1} \\
\hline R5_CR325 & 6 & 8 & 10 & 7 & 0 & 0 & 0 & 0 & \\
\hline R6_CR307 & 5 & 7 & 8 & 5 & 0 & 0 & 0 & 0 & \multirow{2}{*}{1} \\
\hline R7_CR275 & 5 & 7 & 8 & 5 & 0 & 0 & 0 & 0 & \\
\hline R8_CR233 & 13 & 16 & 20 & 14 & 0 & 0 & 0 & 0 & \multirow{2}{*}{0.9957} \\
\hline R9_CR156 & 12 & 16 & 21 & 14 & 0 & 0 & 0 & 0 & \\
\hline
\end{tabular}

u. Replicate 21

\begin{tabular}{|c|c|c|c|c|c|c|c|c|c|}
\hline Release & $E$ & $C$ & $\mathrm{H}$ & G & $B$ & D & $\mathrm{F}$ & $A$ & P-value \\
\hline R1_CR503 & 0 & 0 & 0 & 0 & 20 & 19 & 17 & 23 & \multirow{3}{*}{0.9993} \\
\hline R2_CR468 & 0 & 0 & 0 & 0 & 15 & 16 & 15 & 17 & \\
\hline R3_CR422 & 0 & 0 & 0 & 0 & 15 & 14 & 15 & 18 & \\
\hline R4_CR346 & 7 & 8 & 10 & 6 & 0 & 0 & 0 & 0 & \multirow{2}{*}{0.9887} \\
\hline R5_CR325 & 6 & 8 & 11 & 6 & 0 & 0 & 0 & 0 & \\
\hline R6_CR307 & 5 & 7 & 7 & 6 & 0 & 0 & 0 & 0 & \multirow{2}{*}{0.9861} \\
\hline R7_CR275 & 5 & 6 & 8 & 6 & 0 & 0 & 0 & 0 & \\
\hline R8_CR233 & 13 & 17 & 18 & 15 & 0 & 0 & 0 & 0 & \multirow{2}{*}{0.9814} \\
\hline R9_CR156 & 12 & 16 & 20 & 15 & 0 & 0 & 0 & 0 & \\
\hline
\end{tabular}


Table A.6. (contd)

v. Replicate 22

\begin{tabular}{|c|c|c|c|c|c|c|c|c|c|}
\hline Release & $\mathrm{E}$ & C & $\mathrm{H}$ & G & $\mathrm{B}$ & $\mathrm{D}$ & $\mathrm{F}$ & A & P-value \\
\hline R1_CR503 & 0 & 0 & 0 & 0 & 19 & 19 & 18 & 23 & \multirow{3}{*}{1} \\
\hline R2_CR468 & 0 & 0 & 0 & 0 & 15 & 15 & 15 & 18 & \\
\hline R3_CR422 & 0 & 0 & 0 & 0 & 15 & 16 & 14 & 18 & \\
\hline R4_CR346 & 7 & 8 & 9 & 7 & 0 & 0 & 0 & 0 & \multirow{2}{*}{0.9881} \\
\hline R5_CR325 & 6 & 8 & 10 & 7 & 0 & 0 & 0 & 0 & \\
\hline R6_CR307 & 5 & 7 & 6 & 7 & 0 & 0 & 0 & 0 & \multirow{2}{*}{0.9423} \\
\hline R7_CR275 & 5 & 7 & 7 & 5 & 0 & 0 & 0 & 0 & \\
\hline R8_CR233 & 0 & 0 & 0 & 0 & 14 & 17 & 14 & 18 & \multirow{2}{*}{0.9850} \\
\hline R9_CR156 & 0 & 0 & 0 & 0 & 15 & 15 & 14 & 18 & \\
\hline
\end{tabular}

w. Replicate 23

\begin{tabular}{|c|c|c|c|c|c|c|c|c|c|}
\hline Release & $E$ & $C$ & $\mathrm{H}$ & G & $\mathrm{B}$ & $\mathrm{D}$ & $\mathrm{F}$ & $\mathrm{A}$ & P-value \\
\hline R1_CR503 & 16 & 21 & 24 & 18 & 0 & 0 & 0 & 0 & \multirow{3}{*}{0.9996} \\
\hline R2_CR468 & 13 & 16 & 19 & 15 & 0 & 0 & 0 & 0 & \\
\hline R3_CR422 & 13 & 18 & 19 & 13 & 0 & 0 & 0 & 0 & \\
\hline R4_CR346 & 5 & 9 & 9 & 8 & 0 & 0 & 0 & 0 & \multirow{2}{*}{0.9853} \\
\hline R5_CR325 & 6 & 8 & 9 & 8 & 0 & 0 & 0 & 0 & \\
\hline R6_CR307 & 0 & 0 & 0 & 0 & 6 & 6 & 5 & 8 & \multirow{2}{*}{0.9861} \\
\hline R7_CR275 & 0 & 0 & 0 & 0 & 6 & 7 & 5 & 7 & \\
\hline R8_CR233 & 0 & 0 & 0 & 0 & 15 & 16 & 15 & 17 & \multirow{2}{*}{0.9959} \\
\hline R9_CR156 & 0 & 0 & 0 & 0 & 14 & 16 & 15 & 18 & \\
\hline
\end{tabular}

x. Replicate 24

\begin{tabular}{|c|c|c|c|c|c|c|c|c|c|}
\hline Release & $E$ & $C$ & $\mathrm{H}$ & G & $B$ & $\mathrm{D}$ & $\mathrm{F}$ & $A$ & P-value \\
\hline R1_CR503 & 16 & 21 & 24 & 18 & 0 & 0 & 0 & 0 & \multirow{3}{*}{0.9999} \\
\hline R2_CR468 & 13 & 17 & 20 & 13 & 0 & 0 & 0 & 0 & \\
\hline R3_CR422 & 13 & 17 & 20 & 13 & 0 & 0 & 0 & 0 & \\
\hline R4_CR346 & 0 & 0 & 0 & 0 & 7 & 8 & 7 & 9 & \multirow{2}{*}{1} \\
\hline R5_CR325 & 0 & 0 & 0 & 0 & 7 & 8 & 7 & 9 & \\
\hline R6_CR307 & 0 & 0 & 0 & 0 & 5 & 7 & 6 & 7 & \multirow{2}{*}{1} \\
\hline R7_CR275 & 0 & 0 & 0 & 0 & 5 & 7 & 6 & 7 & \\
\hline R8_CR233 & 0 & 0 & 0 & 0 & 15 & 16 & 14 & 18 & \multirow{2}{*}{0.9953} \\
\hline R9_CR156 & 0 & 0 & 0 & 0 & 14 & 16 & 15 & 18 & \\
\hline
\end{tabular}


Table A.6. (contd)

y. Replicate 25

\begin{tabular}{|c|c|c|c|c|c|c|c|c|c|}
\hline Release & $\mathrm{E}$ & $\mathrm{C}$ & $\mathrm{H}$ & G & $\mathrm{B}$ & $\mathrm{D}$ & $\mathrm{F}$ & A & P-value \\
\hline R1_CR503 & 16 & 22 & 23 & 17 & 0 & 0 & 0 & 0 & \multirow{3}{*}{0.9999} \\
\hline R2_CR468 & 13 & 17 & 19 & 13 & 0 & 0 & 0 & 0 & \\
\hline R3_CR422 & 13 & 17 & 18 & 15 & 0 & 0 & 0 & 0 & \\
\hline R4_CR346 & 0 & 0 & 0 & 0 & 7 & 9 & 7 & 8 & \multirow{2}{*}{0.9886} \\
\hline R5_CR325 & 0 & 0 & 0 & 0 & 8 & 8 & 7 & 8 & \\
\hline R6_CR307 & 0 & 0 & 0 & 0 & 6 & 6 & 6 & 7 & \multirow{2}{*}{0.9826} \\
\hline R7_CR275 & 0 & 0 & 0 & 0 & 5 & 7 & 6 & 7 & \\
\hline R8_CR233 & 0 & 0 & 0 & 0 & 16 & 15 & 15 & 17 & \multirow{2}{*}{0.9847} \\
\hline R9_CR156 & 0 & 0 & 0 & 0 & 14 & 15 & 15 & 18 & \\
\hline
\end{tabular}

z. Replicate 26

\begin{tabular}{|c|c|c|c|c|c|c|c|c|c|}
\hline Release & $E$ & C & $\mathrm{H}$ & G & B & D & $\mathrm{F}$ & A & $\mathrm{P}$-value \\
\hline R1_CR503 & 16 & 21 & 26 & 16 & 0 & 0 & 0 & 0 & \multirow{3}{*}{0.9846} \\
\hline R2_CR468 & 13 & 15 & 19 & 16 & 0 & 0 & 0 & 0 & \\
\hline R3_CR422 & 11 & 18 & 19 & 15 & 0 & 0 & 0 & 0 & \\
\hline R4_CR346 & 0 & 0 & 0 & 0 & 8 & 7 & 7 & 9 & \multirow{2}{*}{0.9669} \\
\hline R5_CR325 & 0 & 0 & 0 & 0 & 7 & 8 & 6 & 10 & \\
\hline R6_CR307 & 0 & 0 & 0 & 0 & 6 & 6 & 6 & 7 & \multirow{2}{*}{1} \\
\hline R7_CR275 & 0 & 0 & 0 & 0 & 6 & 6 & 6 & 7 & \\
\hline R8_CR233 & 13 & 19 & 19 & 12 & 0 & 0 & 0 & 0 & \multirow{2}{*}{0.8913} \\
\hline R9_CR156 & 12 & 16 & 19 & 15 & 0 & 0 & 0 & 0 & \\
\hline
\end{tabular}

aa. Replicate 27

\begin{tabular}{|c|c|c|c|c|c|c|c|c|c|}
\hline Release & $E$ & C & $\mathrm{H}$ & G & $B$ & $\mathrm{D}$ & $\mathrm{F}$ & $A$ & P-value \\
\hline R1_CR503 & 0 & 0 & 0 & 0 & 19 & 20 & 17 & 23 & \multirow{3}{*}{0.9996} \\
\hline R2_CR468 & 0 & 0 & 0 & 0 & 16 & 17 & 14 & 16 & \\
\hline R3_CR422 & 0 & 0 & 0 & 0 & 15 & 17 & 14 & 17 & \\
\hline R4_CR346 & 0 & 0 & 0 & 0 & 7 & 7 & 7 & 10 & \multirow{2}{*}{0.9436} \\
\hline R5_CR325 & 0 & 0 & 0 & 0 & 7 & 8 & 5 & 10 & \\
\hline R6_CR307 & 5 & 6 & 9 & 5 & 0 & 0 & 0 & 0 & \multirow{2}{*}{0.9853} \\
\hline R7_CR275 & 5 & 6 & 8 & 6 & 0 & 0 & 0 & 0 & \\
\hline R8_CR233 & 12 & 16 & 22 & 13 & 0 & 0 & 0 & 0 & \multirow{2}{*}{0.9581} \\
\hline R9_CR156 & 13 & 15 & 20 & 15 & 0 & 0 & 0 & 0 & \\
\hline
\end{tabular}


Table A.6. (contd)

bb. Replicate 28

\begin{tabular}{cccccccccc}
\hline Release & E & C & H & G & B & D & F & A & P-value \\
\hline R1_CR503 & 0 & 0 & 0 & 0 & 19 & 20 & 18 & 21 \\
R2_CR468 & 0 & 0 & 0 & 0 & 15 & 15 & 14 & 19 & 0.9998 \\
R3_CR422 & 0 & 0 & 0 & 0 & 15 & 16 & 14 & 18 & 0 \\
\hline R4_CR346 & 7 & 8 & 10 & 6 & 0 & 0 & 0 & 0 \\
R5_CR325 & 6 & 8 & 10 & 7 & 0 & 0 & 0 & 0 \\
\hline R6_CR307 & 5 & 6 & 7 & 7 & 0 & 0 & 0 & 0 \\
R7_CR275 & 5 & 6 & 8 & 6 & 0 & 0 & 0 & 0 & 0.9847 \\
\hline R8_CR233 & 13 & 15 & 19 & 16 & 0 & 0 & 0 & 0 & \multirow{2}{*}{0.9819} \\
R9_CR156 & 12 & 15 & 21 & 15 & 0 & 0 & 0 & 0 & 0.0001
\end{tabular}

cc. Replicate 29

\begin{tabular}{|c|c|c|c|c|c|c|c|c|c|}
\hline Release & $E$ & C & $\mathrm{H}$ & G & B & D & $\mathrm{F}$ & A & $\mathrm{P}$-value \\
\hline R1_CR503 & 0 & 0 & 0 & 0 & 19 & 20 & 17 & 23 & \multirow{3}{*}{1} \\
\hline R2_CR468 & 0 & 0 & 0 & 0 & 15 & 16 & 14 & 18 & \\
\hline R3_CR422 & 0 & 0 & 0 & 0 & 15 & 15 & 15 & 18 & \\
\hline R4_CR346 & 7 & 7 & 10 & 7 & 0 & 0 & 0 & 0 & \multirow{2}{*}{0.9861} \\
\hline R5_CR325 & 6 & 8 & 10 & 7 & 0 & 0 & 0 & 0 & \\
\hline R6_CR307 & 5 & 6 & 8 & 6 & 0 & 0 & 0 & 0 & \multirow{2}{*}{0.9861} \\
\hline R7_CR275 & 5 & 7 & 7 & 6 & 0 & 0 & 0 & 0 & \\
\hline R8_CR233 & 12 & 16 & 20 & 15 & 0 & 0 & 0 & 0 & \multirow{2}{*}{0.9881} \\
\hline R9_CR156 & 12 & 16 & 18 & 16 & 0 & 0 & 0 & 0 & \\
\hline
\end{tabular}

dd. Replicate 30

\begin{tabular}{|c|c|c|c|c|c|c|c|c|c|}
\hline Release & $E$ & $C$ & $\mathrm{H}$ & $\mathrm{G}$ & $B$ & $\mathrm{D}$ & $\mathrm{F}$ & $A$ & P-value \\
\hline R1_CR503 & 0 & 0 & 0 & 0 & 19 & 21 & 17 & 22 & \multirow{3}{*}{0.9998} \\
\hline R2_CR468 & 0 & 0 & 0 & 0 & 14 & 17 & 15 & 17 & \\
\hline R3_CR422 & 0 & 0 & 0 & 0 & 14 & 17 & 15 & 17 & \\
\hline R4_CR346 & 6 & 8 & 9 & 7 & 0 & 0 & 0 & 0 & \multirow{2}{*}{0.9392} \\
\hline R5_CR325 & 6 & 6 & 10 & 8 & 0 & 0 & 0 & 0 & \\
\hline R6_CR307 & 5 & 6 & 8 & 6 & 0 & 0 & 0 & 0 & \multirow{2}{*}{0.9795} \\
\hline R7_CR275 & 4 & 7 & 8 & 6 & 0 & 0 & 0 & 0 & \\
\hline R8_CR233 & 0 & 0 & 0 & 0 & 14 & 16 & 14 & 19 & \multirow{2}{*}{0.9960} \\
\hline R9_CR156 & 0 & 0 & 0 & 0 & 15 & 16 & 14 & 18 & \\
\hline
\end{tabular}


Table A.6. (contd)

ee. Replicate 31

\begin{tabular}{cccccccccc}
\hline Release & E & C & H & G & B & D & F & A & P-value \\
\hline R1_CR503 & 18 & 22 & 26 & 21 & 0 & 0 & 0 & 0 \\
R2_CR468 & 12 & 13 & 19 & 15 & 0 & 0 & 0 & 0 & 0.9994 \\
R3_CR422 & 10 & 11 & 16 & 12 & 0 & 0 & 0 & 0 & 0 \\
\hline R4_CR346 & 5 & 6 & 7 & 6 & 0 & 0 & 0 & 0 \\
R5_CR325 & 5 & 6 & 8 & 6 & 0 & 0 & 0 & 0 \\
\hline R6_CR307 & 0 & 0 & 0 & 0 & 4 & 5 & 4 & 6 & \multirow{2}{*}{0.9773} \\
R7_CR275 & 0 & 0 & 0 & 0 & 4 & 5 & 5 & 5 \\
\hline R8_CR233 & 0 & 0 & 0 & 0 & 12 & 13 & 13 & 17 & \multirow{2}{*}{0.9754} \\
R9_CR156 & 0 & 0 & 0 & 0 & 12 & 15 & 12 & 16 & $<0.0001$
\end{tabular}

ff. Replicate 32

\begin{tabular}{|c|c|c|c|c|c|c|c|c|c|}
\hline Release & $\mathrm{E}$ & $\mathrm{C}$ & $\mathrm{H}$ & $\mathrm{G}$ & $\mathrm{B}$ & $\mathrm{D}$ & $\mathrm{F}$ & $\mathrm{A}$ & P-value \\
\hline R1_CR503 & 15 & 22 & 26 & 18 & 0 & 0 & 0 & 0 & \multirow{3}{*}{0.9986} \\
\hline R2_CR468 & 11 & 14 & 18 & 11 & 0 & 0 & 0 & 0 & \\
\hline R3_CR422 & 8 & 12 & 17 & 11 & 0 & 0 & 0 & 0 & \\
\hline R4_CR346 & 0 & 0 & 0 & 0 & 6 & 6 & 6 & 7 & \multirow{2}{*}{0.9951} \\
\hline R5_CR325 & 0 & 0 & 0 & 0 & 6 & 6 & 5 & 7 & \\
\hline R6_CR307 & 0 & 0 & 0 & 0 & 5 & 5 & 4 & 5 & \multirow{2}{*}{0.9773} \\
\hline R7_CR275 & 0 & 0 & 0 & 0 & 4 & 5 & 4 & 6 & \\
\hline R8_CR233 & 0 & 0 & 0 & 0 & 13 & 13 & 12 & 17 & \multirow{2}{*}{0.9773} \\
\hline R9_CR156 & 0 & 0 & 0 & 0 & 13 & 14 & 13 & 15 & \\
\hline
\end{tabular}


Table A.7. Estimates of reach and cumulative survival for subyearling Chinook salmon and associated $F$-test of homogeneous survival across fish tagged by different staff members.

a. Release 1 - Reach survival

\begin{tabular}{|c|c|c|c|c|c|c|c|c|c|c|c|c|c|c|c|c|c|c|}
\hline & \multicolumn{2}{|c|}{$\begin{array}{c}\text { Release to } \\
\text { CR470.0 }\end{array}$} & \multicolumn{2}{|c|}{$\begin{array}{l}\text { CR470.0 to } \\
\text { CR422.0 }\end{array}$} & \multicolumn{2}{|c|}{$\begin{array}{l}\text { CR422.0 to } \\
\text { CR349.0 }\end{array}$} & \multicolumn{2}{|c|}{$\begin{array}{c}\text { CR349.0 to } \\
\text { CR325.0 }\end{array}$} & \multicolumn{2}{|c|}{$\begin{array}{c}\text { CR325.0 to } \\
\text { CR309.0 }\end{array}$} & \multicolumn{2}{|c|}{$\begin{array}{l}\text { CR309.0 to } \\
\text { CR275.0 }\end{array}$} & \multicolumn{2}{|c|}{$\begin{array}{c}\text { CR275.0 to } \\
\text { CR234.0 }\end{array}$} & \multicolumn{2}{|c|}{$\begin{array}{c}\text { CR234.0 to } \\
\text { CR156.0 }\end{array}$} & \multicolumn{2}{|c|}{$\begin{array}{l}\text { CR156.0 to } \\
\text { CR113.0 }\end{array}$} \\
\hline & Est & SE & Est & SE & Est & SE & Est & SE & Est & SE & Est & SE & Est & SE & Est & SE & Est & SE \\
\hline A & 0.9777 & 0.0078 & 0.9229 & 0.0143 & 0.9505 & 0.0121 & 0.9375 & 0.0139 & 0.9860 & 0.0070 & 0.9395 & 0.0142 & 0.9889 & 0.0065 & 0.9468 & 0.0147 & 0.9768 & 0.0106 \\
\hline B & 0.9841 & 0.0072 & 0.9175 & 0.0158 & 0.9465 & 0.0135 & 0.9198 & 0.0168 & 0.9962 & 0.0041 & 0.9167 & 0.0178 & 1.0002 & 0.0002 & 0.9531 & 0.0150 & 0.9887 & 0.0083 \\
\hline C & 0.9908 & 0.0053 & 0.8920 & 0.0172 & 0.9412 & 0.0138 & 0.9449 & 0.0138 & 0.9961 & 0.0039 & 0.9570 & 0.0127 & 0.9926 & 0.0058 & 0.9399 & 0.0158 & 0.9954 & 0.0054 \\
\hline D & 0.9803 & 0.0080 & 0.9161 & 0.0161 & 0.9560 & 0.0124 & 0.9387 & 0.0148 & 0.9878 & 0.0070 & 0.9504 & 0.0140 & 0.9957 & 0.0043 & 0.9550 & 0.0139 & 1.0012 & 0.0007 \\
\hline $\mathrm{E}$ & 0.9647 & 0.0116 & 0.9228 & 0.0170 & 0.9604 & 0.0130 & 0.9447 & 0.0155 & 0.9951 & 0.0049 & 0.9559 & 0.0144 & 0.9694 & 0.0124 & 0.9730 & 0.0122 & 0.9941 & 0.0063 \\
\hline $\mathrm{F}$ & 0.9759 & 0.0091 & 0.9247 & 0.0158 & 0.9537 & 0.0131 & 0.9271 & 0.0165 & 0.9913 & 0.0061 & 0.9427 & 0.0154 & 0.9953 & 0.0047 & 0.9476 & 0.0155 & 0.9949 & 0.0056 \\
\hline G & 0.9721 & 0.0097 & 0.9104 & 0.0171 & 0.9724 & 0.0103 & 0.9224 & 0.0171 & 0.9779 & 0.0098 & 0.9910 & 0.0064 & 0.9822 & 0.0091 & 0.9480 & 0.0155 & 0.9893 & 0.0077 \\
\hline $\mathrm{H}$ & 0.9748 & 0.0079 & 0.9093 & 0.0146 & 0.9573 & 0.0108 & 0.9521 & 0.0117 & 1.0000 & 0.0000 & 0.9497 & 0.0123 & 0.9967 & 0.0033 & 0.9493 & 0.0132 & 0.9803 & 0.0090 \\
\hline$P$-value & \multicolumn{2}{|c|}{0.5443} & \multicolumn{2}{|c|}{0.8721} & \multicolumn{2}{|c|}{0.7766} & \multicolumn{2}{|c|}{0.7610} & \multicolumn{2}{|c|}{0.2749} & \multicolumn{2}{|c|}{0.0246} & \multicolumn{2}{|c|}{0.0307} & \multicolumn{2}{|c|}{0.8701} & \multicolumn{2}{|c|}{0.2653} \\
\hline
\end{tabular}

b. Release 1 - Cumulative survival

\begin{tabular}{|c|c|c|c|c|c|c|c|c|c|c|c|c|c|c|c|c|c|c|}
\hline & \multicolumn{2}{|c|}{$\begin{array}{c}\text { Release to } \\
\text { CR470.0 }\end{array}$} & \multicolumn{2}{|c|}{$\begin{array}{c}\text { Release to } \\
\text { CR422.0 }\end{array}$} & \multicolumn{2}{|c|}{$\begin{array}{c}\text { Release to } \\
\text { CR349.0 }\end{array}$} & \multicolumn{2}{|c|}{$\begin{array}{c}\text { Release to } \\
\text { CR325.0 }\end{array}$} & \multicolumn{2}{|c|}{$\begin{array}{c}\text { Release to } \\
\text { CR309.0 }\end{array}$} & \multicolumn{2}{|c|}{$\begin{array}{c}\text { Release to } \\
\text { CR275.0 }\end{array}$} & \multicolumn{2}{|c|}{$\begin{array}{l}\text { Release to } \\
\text { CR234.0 }\end{array}$} & \multicolumn{2}{|c|}{$\begin{array}{c}\text { Release to } \\
\text { CR156.0 }\end{array}$} & \multicolumn{2}{|c|}{$\begin{array}{c}\text { Release to } \\
\text { CR113.0 }\end{array}$} \\
\hline & Est & SE & Est & SE & Est & SE & Est & SE & Est & SE & Est & SE & Est & SE & Est & SE & Est & SE \\
\hline A & 0.9777 & 0.0078 & 0.9022 & 0.0157 & 0.8575 & 0.0185 & 0.8039 & 0.0210 & 0.7927 & 0.0215 & 0.7447 & 0.0231 & 0.7364 & 0.0234 & 0.6973 & 0.0246 & 0.6811 & 0.0249 \\
\hline B & 0.9841 & 0.0072 & 0.9029 & 0.0168 & 0.8547 & 0.0201 & 0.7861 & 0.0233 & 0.7832 & 0.0235 & 0.7179 & 0.0256 & 0.7181 & 0.0256 & 0.6844 & 0.0267 & 0.6766 & 0.0268 \\
\hline C & 0.9908 & 0.0053 & 0.8838 & 0.0177 & 0.8318 & 0.0207 & 0.7859 & 0.0227 & 0.7829 & 0.0228 & 0.7492 & 0.0240 & 0.7437 & 0.0242 & 0.6990 & 0.0255 & 0.6958 & 0.0256 \\
\hline D & 0.9803 & 0.0080 & 0.8980 & 0.0174 & 0.8586 & 0.0200 & 0.8059 & 0.0227 & 0.7961 & 0.0231 & 0.7566 & 0.0246 & 0.7533 & 0.0247 & 0.7194 & 0.0258 & 0.7202 & 0.0259 \\
\hline $\mathrm{E}$ & 0.9647 & 0.0116 & 0.8902 & 0.0196 & 0.8549 & 0.0221 & 0.8076 & 0.0247 & 0.8037 & 0.0249 & 0.7682 & 0.0265 & 0.7447 & 0.0273 & 0.7246 & 0.0281 & 0.7204 & 0.0282 \\
\hline $\mathrm{F}$ & 0.9759 & 0.0091 & 0.9024 & 0.0175 & 0.8606 & 0.0204 & 0.7979 & 0.0237 & 0.7909 & 0.0240 & 0.7456 & 0.0257 & 0.7422 & 0.0258 & 0.7033 & 0.0270 & 0.6997 & 0.0271 \\
\hline G & 0.9721 & 0.0097 & 0.8850 & 0.0188 & 0.8606 & 0.0204 & 0.7939 & 0.0239 & 0.7763 & 0.0246 & 0.7693 & 0.0249 & 0.7556 & 0.0254 & 0.7163 & 0.0268 & 0.7087 & 0.0270 \\
\hline H & 0.9748 & 0.0079 & 0.8864 & 0.0159 & 0.8485 & 0.0180 & 0.8079 & 0.0198 & 0.8079 & 0.0198 & 0.7672 & 0.0213 & 0.7647 & 0.0213 & 0.7259 & 0.0226 & 0.7116 & 0.0230 \\
\hline$P$-value & \multicolumn{2}{|c|}{0.5443} & \multicolumn{2}{|c|}{0.9784} & \multicolumn{2}{|c|}{0.9788} & \multicolumn{2}{|c|}{0.9923} & \multicolumn{2}{|c|}{0.9813} & \multicolumn{2}{|c|}{0.8396} & \multicolumn{2}{|c|}{0.9452} & \multicolumn{2}{|c|}{0.9396} & \multicolumn{2}{|c|}{0.8998} \\
\hline
\end{tabular}


Table A.7. (contd)

c. Release 2-Reach survival

\begin{tabular}{|c|c|c|c|c|c|c|c|c|c|c|c|c|c|c|c|c|c|c|}
\hline & & & \multicolumn{2}{|c|}{$\begin{array}{c}\text { Release to } \\
\text { CR422.0 }\end{array}$} & \multicolumn{2}{|c|}{$\begin{array}{c}\text { CR422.0 to } \\
\text { CR349.0 }\end{array}$} & \multicolumn{2}{|c|}{$\begin{array}{c}\text { CR349.0 to } \\
\text { CR325.0 }\end{array}$} & \multicolumn{2}{|c|}{$\begin{array}{c}\text { CR325.0 to } \\
\text { CR309.0 }\end{array}$} & \multicolumn{2}{|c|}{$\begin{array}{c}\text { CR309.0 to } \\
\text { CR275.0 }\end{array}$} & \multicolumn{2}{|c|}{$\begin{array}{c}\text { CR275.0 to } \\
\text { CR234.0 }\end{array}$} & \multicolumn{2}{|c|}{$\begin{array}{c}\text { CR234.0 to } \\
\text { CR156.0 }\end{array}$} & \multicolumn{2}{|c|}{$\begin{array}{c}\text { CR156.0 to } \\
\text { CR113.0 }\end{array}$} \\
\hline & Est & SE & Est & SE & Est & SE & Est & SE & Est & SE & Est & SE & Est & SE & Est & SE & Est & SE \\
\hline A & & & 0.9296 & 0.0152 & 0.9394 & 0.0147 & 0.9673 & 0.0114 & 0.9876 & 0.0073 & 0.9442 & 0.0150 & 0.9864 & 0.0078 & 0.9367 & 0.0166 & 0.9896 & 0.0076 \\
\hline B & & & 0.9205 & 0.0175 & 0.9636 & 0.0126 & 0.9426 & 0.0161 & 0.9848 & 0.0087 & 0.9433 & 0.0166 & 0.9891 & 0.0077 & 0.9826 & 0.0112 & 0.9671 & 0.0145 \\
\hline C & & & 0.9228 & 0.0170 & 0.9648 & 0.0122 & 0.9401 & 0.0161 & 0.9904 & 0.0069 & 0.9602 & 0.0138 & 0.9848 & 0.0089 & 0.9586 & 0.0146 & 0.9940 & 0.0062 \\
\hline D & & & 0.9194 & 0.0173 & 0.9430 & 0.0154 & 0.9206 & 0.0185 & 0.9848 & 0.0087 & 0.9381 & 0.0173 & 0.9835 & 0.0094 & 0.9835 & 0.0114 & 0.9616 & 0.0161 \\
\hline $\mathrm{E}$ & & & 0.9353 & 0.0173 & 0.9468 & 0.0164 & 0.9326 & 0.0188 & 0.9880 & 0.0085 & 0.9329 & 0.0195 & 0.9804 & 0.0112 & 0.9617 & 0.0161 & 0.9844 & 0.0110 \\
\hline $\mathrm{F}$ & & & 0.9277 & 0.0169 & 0.9404 & 0.0160 & 0.9513 & 0.0150 & 0.9897 & 0.0073 & 0.9430 & 0.0167 & 0.9949 & 0.0055 & 0.9399 & 0.0179 & 0.9876 & 0.0090 \\
\hline G & & & 0.9330 & 0.0167 & 0.9713 & 0.0116 & 0.9307 & 0.0179 & 1.0004 & 0.0004 & 0.9305 & 0.0186 & 0.9945 & 0.0057 & 0.9607 & 0.0152 & 0.9862 & 0.0097 \\
\hline $\mathrm{H}$ & & & 0.9177 & 0.0155 & 0.9655 & 0.0107 & 0.9534 & 0.0126 & 0.9887 & 0.0065 & 0.9354 & 0.0152 & 0.9837 & 0.0081 & 0.9550 & 0.0134 & 0.9951 & 0.0048 \\
\hline$P$-value & & & \multicolumn{2}{|c|}{0.9932} & \multicolumn{2}{|c|}{0.5042} & \multicolumn{2}{|c|}{0.5409} & \multicolumn{2}{|c|}{0.8623} & \multicolumn{2}{|c|}{0.9499} & \multicolumn{2}{|c|}{0.8961} & \multicolumn{2}{|c|}{0.2245} & \multicolumn{2}{|c|}{0.2164} \\
\hline
\end{tabular}

d. Release 2-Cumulative survival

\begin{tabular}{|c|c|c|c|c|c|c|c|c|c|c|c|c|c|c|c|c|c|c|}
\hline & & & \multicolumn{2}{|c|}{$\begin{array}{l}\text { Release to } \\
\text { CR422.0 }\end{array}$} & \multicolumn{2}{|c|}{$\begin{array}{c}\text { Release to } \\
\text { CR349.0 }\end{array}$} & \multicolumn{2}{|c|}{$\begin{array}{c}\text { Release to } \\
\text { CR325.0 }\end{array}$} & \multicolumn{2}{|c|}{$\begin{array}{c}\text { Release to } \\
\text { CR309.0 }\end{array}$} & \multicolumn{2}{|c|}{$\begin{array}{c}\text { Release to } \\
\text { CR275.0 }\end{array}$} & \multicolumn{2}{|c|}{$\begin{array}{c}\text { Release to } \\
\text { CR234.0 }\end{array}$} & \multicolumn{2}{|c|}{$\begin{array}{c}\text { Release to } \\
\text { CR156.0 }\end{array}$} & \multicolumn{2}{|c|}{$\begin{array}{c}\text { Release to } \\
\text { CR113.0 }\end{array}$} \\
\hline & Est & SE & Est & SE & Est & SE & Est & SE & Est & SE & Est & SE & Est & SE & Est & SE & Est & SE \\
\hline A & & & 0.9296 & 0.0152 & 0.8732 & 0.0197 & 0.8447 & 0.0215 & 0.8342 & 0.0221 & 0.7877 & 0.0243 & 0.7770 & 0.0248 & 0.7278 & 0.0266 & 0.7202 & 0.0268 \\
\hline B & & & 0.9205 & 0.0175 & 0.8870 & 0.0205 & 0.8361 & 0.0240 & 0.8234 & 0.0247 & 0.7767 & 0.0270 & 0.7682 & 0.0274 & 0.7548 & 0.0283 & 0.7300 & 0.0289 \\
\hline C & & & 0.9228 & 0.0170 & 0.8902 & 0.0199 & 0.8369 & 0.0236 & 0.8289 & 0.0241 & 0.7959 & 0.0258 & 0.7838 & 0.0263 & 0.7513 & 0.0277 & 0.7468 & 0.0278 \\
\hline D & & & 0.9194 & 0.0173 & 0.8669 & 0.0216 & 0.7981 & 0.0255 & 0.7859 & 0.0261 & 0.7373 & 0.0280 & 0.7251 & 0.0284 & 0.7132 & 0.0291 & 0.6858 & 0.0296 \\
\hline $\mathrm{E}$ & & & 0.9353 & 0.0173 & 0.8856 & 0.0225 & 0.8259 & 0.0267 & 0.8159 & 0.0273 & 0.7612 & 0.0301 & 0.7463 & 0.0307 & 0.7177 & 0.0319 & 0.7065 & 0.0321 \\
\hline $\mathrm{F}$ & & & 0.9277 & 0.0169 & 0.8723 & 0.0218 & 0.8298 & 0.0245 & 0.8213 & 0.0250 & 0.7745 & 0.0273 & 0.7705 & 0.0275 & 0.7242 & 0.0292 & 0.7152 & 0.0295 \\
\hline G & & & 0.9330 & 0.0167 & 0.9063 & 0.0195 & 0.8434 & 0.0243 & 0.8438 & 0.0243 & 0.7851 & 0.0275 & 0.7808 & 0.0277 & 0.7501 & 0.0291 & 0.7398 & 0.0294 \\
\hline $\mathrm{H}$ & & & 0.9177 & 0.0155 & 0.8861 & 0.0179 & 0.8448 & 0.0204 & 0.8353 & 0.0209 & 0.7813 & 0.0233 & 0.7686 & 0.0238 & 0.7340 & 0.0249 & 0.7305 & 0.0250 \\
\hline$P$-value & & & \multicolumn{2}{|c|}{0.9932} & \multicolumn{2}{|c|}{0.9183} & \multicolumn{2}{|c|}{0.8893} & \multicolumn{2}{|c|}{0.8190} & \multicolumn{2}{|c|}{0.8566} & \multicolumn{2}{|c|}{0.8114} & \multicolumn{2}{|c|}{0.9441} & \multicolumn{2}{|c|}{0.8622} \\
\hline
\end{tabular}


Table A.7. (contd)

e. Release 3-Reach survival

\begin{tabular}{|c|c|c|c|c|c|c|c|c|c|c|c|c|c|c|c|c|c|c|}
\hline & & & & & \multicolumn{2}{|c|}{$\begin{array}{c}\text { Release to } \\
\text { CR349.0 }\end{array}$} & \multicolumn{2}{|c|}{$\begin{array}{c}\text { CR349.0 to } \\
\text { CR325.0 }\end{array}$} & \multicolumn{2}{|c|}{$\begin{array}{c}\text { CR325.0 to } \\
\text { CR309.0 }\end{array}$} & \multicolumn{2}{|c|}{$\begin{array}{c}\text { CR309.0 to } \\
\text { CR275.0 }\end{array}$} & \multicolumn{2}{|c|}{$\begin{array}{c}\text { CR275.0 to } \\
\text { CR234.0 }\end{array}$} & \multicolumn{2}{|c|}{$\begin{array}{l}\text { CR234.0 to } \\
\text { CR156.0 }\end{array}$} & \multicolumn{2}{|c|}{$\begin{array}{c}\text { CR156.0 to } \\
\text { CR113.0 }\end{array}$} \\
\hline & Est & SE & Est & SE & Est & SE & Est & SE & Est & SE & Est & SE & Est & SE & Est & SE & Est & SE \\
\hline A & & & & & 0.9412 & 0.0138 & 0.9556 & 0.0125 & 0.9767 & 0.0094 & 0.9167 & 0.0174 & 0.9827 & 0.0086 & 0.9571 & 0.0137 & 0.9858 & 0.0086 \\
\hline B & & & & & 0.9372 & 0.0157 & 0.9361 & 0.0165 & 0.9854 & 0.0084 & 0.9356 & 0.0173 & 0.9894 & 0.0074 & 0.9544 & 0.0158 & 0.9811 & 0.0112 \\
\hline C & & & & & 0.9137 & 0.0176 & 0.9348 & 0.0163 & 0.9862 & 0.0080 & 0.9668 & 0.0123 & 0.9954 & 0.0049 & 0.9472 & 0.0159 & 0.9882 & 0.0083 \\
\hline D & & & & & 0.9423 & 0.0151 & 0.9156 & 0.0185 & 1.0000 & 0.0000 & 0.8889 & 0.0218 & 0.9728 & 0.0120 & 0.9285 & 0.0194 & 0.9878 & 0.0093 \\
\hline $\mathrm{E}$ & & & & & 0.9375 & 0.0175 & 0.9333 & 0.0186 & 1.0000 & 0.0000 & 0.9226 & 0.0206 & 0.9935 & 0.0064 & 0.9805 & 0.0111 & 1.0000 & 0.0000 \\
\hline $\mathrm{F}$ & & & & & 0.9534 & 0.0137 & 0.9412 & 0.0158 & 1.0000 & 0.0000 & 0.9471 & 0.0155 & 0.9746 & 0.0112 & 0.9305 & 0.0189 & 0.9630 & 0.0149 \\
\hline G & & & & & 0.9541 & 0.0142 & 0.9614 & 0.0134 & 0.9849 & 0.0086 & 0.9082 & 0.0206 & 0.9944 & 0.0056 & 0.9943 & 0.0057 & 1.0001 & 0.0001 \\
\hline $\mathrm{H}$ & & & & & 0.9490 & 0.0124 & 0.9461 & 0.0131 & 0.9929 & 0.0050 & 0.9570 & 0.0121 & 0.9889 & 0.0065 & 0.9847 & 0.0076 & 1.0001 & 0.0001 \\
\hline$P$-value & & & & & \multicolumn{2}{|c|}{0.6476} & \multicolumn{2}{|c|}{0.5717} & \multicolumn{2}{|c|}{0.2967} & \multicolumn{2}{|c|}{0.0291} & \multicolumn{2}{|c|}{0.3174} & \multicolumn{2}{|c|}{0.0040} & \multicolumn{2}{|c|}{0.0605} \\
\hline
\end{tabular}

f. Release 3-Cumulative survival

\begin{tabular}{|c|c|c|c|c|c|c|c|c|c|c|c|c|c|c|c|c|c|c|}
\hline & & & & & \multicolumn{2}{|c|}{$\begin{array}{c}\text { Release to } \\
\text { CR349.0 }\end{array}$} & \multicolumn{2}{|c|}{$\begin{array}{c}\text { Release to } \\
\text { CR325.0 }\end{array}$} & \multicolumn{2}{|c|}{$\begin{array}{c}\text { Release to } \\
\text { CR309.0 }\end{array}$} & \multicolumn{2}{|c|}{$\begin{array}{l}\text { Release to } \\
\text { CR275.0 }\end{array}$} & \multicolumn{2}{|c|}{$\begin{array}{c}\text { Release to } \\
\text { CR234.0 }\end{array}$} & \multicolumn{2}{|c|}{$\begin{array}{c}\text { Release to } \\
\text { CR156.0 }\end{array}$} & \multicolumn{2}{|c|}{$\begin{array}{c}\text { Release to } \\
\text { CR113.0 }\end{array}$} \\
\hline & Est & SE & Est & SE & Est & SE & Est & SE & Est & SE & Est & SE & Est & SE & Est & SE & Est & SE \\
\hline$A$ & & & & & 0.9412 & 0.0138 & 0.8993 & 0.0177 & 0.8784 & 0.0193 & 0.8052 & 0.0234 & 0.7913 & 0.0240 & 0.7573 & 0.0254 & 0.7465 & 0.0257 \\
\hline B & & & & & 0.9372 & 0.0157 & 0.8773 & 0.0213 & 0.8645 & 0.0223 & 0.8089 & 0.0256 & 0.8003 & 0.0261 & 0.7638 & 0.0279 & 0.7494 & 0.0283 \\
\hline C & & & & & 0.9137 & 0.0176 & 0.8541 & 0.0222 & 0.8424 & 0.0229 & 0.8144 & 0.0244 & 0.8107 & 0.0246 & 0.7679 & 0.0267 & 0.7588 & 0.0269 \\
\hline D & & & & & 0.9423 & 0.0151 & 0.8627 & 0.0222 & 0.8627 & 0.0222 & 0.7669 & 0.0273 & 0.7460 & 0.0281 & 0.6927 & 0.0298 & 0.6842 & 0.0301 \\
\hline $\mathrm{E}$ & & & & & 0.9375 & 0.0175 & 0.8750 & 0.0239 & 0.8750 & 0.0239 & 0.8073 & 0.0285 & 0.8021 & 0.0288 & 0.7865 & 0.0296 & 0.7865 & 0.0296 \\
\hline $\mathrm{F}$ & & & & & 0.9534 & 0.0137 & 0.8973 & 0.0199 & 0.8973 & 0.0199 & 0.8499 & 0.0234 & 0.8283 & 0.0247 & 0.7707 & 0.0278 & 0.7422 & 0.0287 \\
\hline G & & & & & 0.9541 & 0.0142 & 0.9173 & 0.0187 & 0.9034 & 0.0200 & 0.8205 & 0.0260 & 0.8159 & 0.0263 & 0.8112 & 0.0266 & 0.8113 & 0.0266 \\
\hline $\mathrm{H}$ & & & & & 0.9490 & 0.0124 & 0.8979 & 0.0171 & 0.8915 & 0.0176 & 0.8532 & 0.0200 & 0.8437 & 0.0205 & 0.8308 & 0.0212 & 0.8309 & 0.0212 \\
\hline$P$-value & & & & & \multicolumn{2}{|c|}{0.6476} & \multicolumn{2}{|c|}{0.3731} & \multicolumn{2}{|c|}{0.4859} & \multicolumn{2}{|c|}{0.3012} & \multicolumn{2}{|c|}{0.2486} & \multicolumn{2}{|c|}{0.0235} & \multicolumn{2}{|c|}{0.0064} \\
\hline
\end{tabular}


Table A.7. (contd)

g. Release 4 - Reach survival

\begin{tabular}{|c|c|c|c|c|c|c|c|c|c|c|c|c|c|c|c|c|c|c|}
\hline & & & & & & & \multicolumn{2}{|c|}{$\begin{array}{l}\text { Release to } \\
\text { CR325.0 }\end{array}$} & \multicolumn{2}{|c|}{$\begin{array}{c}\text { CR325.0 to } \\
\text { CR309.0 }\end{array}$} & \multicolumn{2}{|c|}{$\begin{array}{c}\text { CR309.0 to } \\
\text { CR275.0 }\end{array}$} & \multicolumn{2}{|c|}{$\begin{array}{c}\text { CR275.0 to } \\
\text { CR234.0 }\end{array}$} & \multicolumn{2}{|c|}{$\begin{array}{l}\text { CR234.0 to } \\
\text { CR156.0 }\end{array}$} & \multicolumn{2}{|c|}{$\begin{array}{c}\text { CR156.0 to } \\
\text { CR113.0 }\end{array}$} \\
\hline & Est & SE & Est & SE & Est & $\mathrm{SE}$ & Est & SE & Est & SE & Est & SE & Est & SE & Est & SE & Est & SE \\
\hline A & & & & & & & 1.0000 & 0.0000 & 1.0000 & 0.0000 & 0.9167 & 0.0230 & 0.9932 & 0.0076 & 0.9535 & 0.0185 & 1.0003 & 0.0003 \\
\hline B & & & & & & & 1.0000 & 0.0000 & 0.9916 & 0.0084 & 0.9576 & 0.0185 & 0.9735 & 0.0151 & 0.9545 & 0.0199 & 1.0004 & 0.0004 \\
\hline C & & & & & & & 1.0000 & 0.0000 & 0.9921 & 0.0079 & 0.9440 & 0.0206 & 0.9831 & 0.0119 & 0.9741 & 0.0147 & 1.0000 & 0.0000 \\
\hline D & & & & & & & 1.0000 & 0.0000 & 1.0000 & 0.0000 & 0.8908 & 0.0286 & 1.0002 & 0.0002 & 0.9830 & 0.0135 & 0.9787 & 0.0149 \\
\hline $\mathrm{E}$ & & & & & & & 1.0000 & 0.0000 & 0.9898 & 0.0102 & 0.9691 & 0.0176 & 0.9894 & 0.0106 & 0.9469 & 0.0234 & 0.9891 & 0.0121 \\
\hline $\mathrm{F}$ & & & & & & & 1.0000 & 0.0000 & 1.0000 & 0.0000 & 0.9483 & 0.0206 & 1.0000 & 0.0000 & 0.9737 & 0.0156 & 0.9897 & 0.0103 \\
\hline G & & & & & & & 1.0000 & 0.0000 & 1.0000 & 0.0000 & 0.9459 & 0.0215 & 0.9905 & 0.0095 & 0.9712 & 0.0164 & 1.0000 & 0.0000 \\
\hline $\mathrm{H}$ & & & & & & & 0.9935 & 0.0065 & 0.9934 & 0.0066 & 0.9404 & 0.0193 & 0.9932 & 0.0070 & 0.9722 & 0.0141 & 0.9919 & 0.0080 \\
\hline$P$-value & & & & & & & \multicolumn{2}{|c|}{0.9966} & \multicolumn{2}{|c|}{0.9572} & \multicolumn{2}{|c|}{0.2388} & \multicolumn{2}{|c|}{0.5865} & \multicolumn{2}{|c|}{0.8045} & \multicolumn{2}{|c|}{0.6814} \\
\hline
\end{tabular}

h. Release 4-Cumulative survival

\begin{tabular}{|c|c|c|c|c|c|c|c|c|c|c|c|c|c|c|c|c|c|c|}
\hline & & & & & & & \multicolumn{2}{|c|}{$\begin{array}{l}\text { Release to } \\
\text { CR325.0 }\end{array}$} & \multicolumn{2}{|c|}{$\begin{array}{c}\text { Release to } \\
\text { CR309.0 }\end{array}$} & \multicolumn{2}{|c|}{$\begin{array}{l}\text { Release to } \\
\text { CR275.0 }\end{array}$} & \multicolumn{2}{|c|}{$\begin{array}{c}\text { Release to } \\
\text { CR234.0 }\end{array}$} & \multicolumn{2}{|c|}{$\begin{array}{c}\text { Release to } \\
\text { CR156.0 }\end{array}$} & \multicolumn{2}{|c|}{$\begin{array}{c}\text { Release to } \\
\text { CR113.0 }\end{array}$} \\
\hline & Est & SE & Est & SE & Est & SE & Est & SE & Est & SE & Est & SE & Est & SE & Est & SE & Est & SE \\
\hline A & & & & & & & 1.0000 & 0.0000 & 1.0000 & 0.0000 & 0.9167 & 0.0230 & 0.9104 & 0.0239 & 0.8681 & 0.0282 & 0.8683 & 0.0282 \\
\hline B & & & & & & & 1.0000 & 0.0000 & 0.9916 & 0.0084 & 0.9496 & 0.0201 & 0.9244 & 0.0242 & 0.8824 & 0.0295 & 0.8827 & 0.0295 \\
\hline C & & & & & & & 1.0000 & 0.0000 & 0.9921 & 0.0079 & 0.9365 & 0.0217 & 0.9206 & 0.0241 & 0.8968 & 0.0271 & 0.8968 & 0.0271 \\
\hline D & & & & & & & 1.0000 & 0.0000 & 1.0000 & 0.0000 & 0.8908 & 0.0286 & 0.8909 & 0.0286 & 0.8758 & 0.0305 & 0.8571 & 0.0321 \\
\hline $\mathrm{E}$ & & & & & & & 1.0000 & 0.0000 & 0.9898 & 0.0102 & 0.9592 & 0.0200 & 0.9490 & 0.0222 & 0.8986 & 0.0306 & 0.8888 & 0.0319 \\
\hline $\mathrm{F}$ & & & & & & & 1.0000 & 0.0000 & 1.0000 & 0.0000 & 0.9483 & 0.0206 & 0.9483 & 0.0206 & 0.9233 & 0.0249 & 0.9138 & 0.0261 \\
\hline G & & & & & & & 1.0000 & 0.0000 & 1.0000 & 0.0000 & 0.9459 & 0.0215 & 0.9369 & 0.0231 & 0.9099 & 0.0272 & 0.9099 & 0.0272 \\
\hline $\mathrm{H}$ & & & & & & & 0.9935 & 0.0065 & 0.9869 & 0.0092 & 0.9281 & 0.0209 & 0.9218 & 0.0217 & 0.8961 & 0.0248 & 0.8889 & 0.0254 \\
\hline$P$-value & & & & & & & \multicolumn{2}{|c|}{0.9966} & \multicolumn{2}{|c|}{0.9159} & \multicolumn{2}{|c|}{0.4336} & \multicolumn{2}{|c|}{0.6888} & \multicolumn{2}{|c|}{0.8919} & \multicolumn{2}{|c|}{0.8673} \\
\hline
\end{tabular}


Table A.7. (contd)

i. Release 5-Reach survival

\begin{tabular}{|c|c|c|c|c|c|c|c|c|c|c|c|c|c|c|c|c|c|c|}
\hline & & & & & & & & & \multicolumn{2}{|c|}{$\begin{array}{l}\text { Release to } \\
\text { CR309.0 }\end{array}$} & \multicolumn{2}{|c|}{$\begin{array}{l}\text { CR309.0 to } \\
\text { CR275.0 }\end{array}$} & \multicolumn{2}{|c|}{$\begin{array}{l}\text { CR275.0 to } \\
\text { CR234.0 }\end{array}$} & \multicolumn{2}{|c|}{$\begin{array}{l}\text { CR234.0 to } \\
\text { CR156.0 }\end{array}$} & \multicolumn{2}{|c|}{$\begin{array}{l}\text { CR156.0 to } \\
\text { CR113.0 }\end{array}$} \\
\hline & Est & SE & Est & SE & Est & $\mathrm{SE}$ & Est & SE & Est & SE & Est & SE & Est & SE & Est & SE & Est & SE \\
\hline$A$ & & & & & & & & & 0.9931 & 0.0069 & 0.9510 & 0.0180 & 1.0002 & 0.0002 & 0.9787 & 0.0127 & 0.9840 & 0.0112 \\
\hline B & & & & & & & & & 0.9832 & 0.0118 & 0.9402 & 0.0219 & 1.0015 & 0.0012 & 0.9252 & 0.0254 & 1.0000 & 0.0000 \\
\hline C & & & & & & & & & 1.0000 & 0.0000 & 0.9187 & 0.0246 & 1.0002 & 0.0003 & 0.9732 & 0.0153 & 1.0003 & 0.0003 \\
\hline D & & & & & & & & & 0.9918 & 0.0082 & 0.9752 & 0.0141 & 1.0000 & 0.0000 & 0.9658 & 0.0168 & 1.0003 & 0.0004 \\
\hline $\mathrm{E}$ & & & & & & & & & 0.9892 & 0.0107 & 0.9130 & 0.0294 & 0.9881 & 0.0118 & 0.9639 & 0.0205 & 1.0015 & 0.0012 \\
\hline $\mathrm{F}$ & & & & & & & & & 0.9910 & 0.0090 & 0.9545 & 0.0199 & 1.0000 & 0.0000 & 0.9631 & 0.0187 & 0.9891 & 0.0111 \\
\hline G & & & & & & & & & 1.0000 & 0.0000 & 0.9561 & 0.0192 & 1.0004 & 0.0004 & 0.9630 & 0.0182 & 1.0000 & 0.0000 \\
\hline $\mathrm{H}$ & & & & & & & & & 0.9809 & 0.0109 & 0.9610 & 0.0156 & 1.0002 & 0.0003 & 0.9667 & 0.0150 & 0.9936 & 0.0077 \\
\hline$P$-value & & & & & & & & & \multicolumn{2}{|c|}{0.8337} & \multicolumn{2}{|c|}{0.4055} & \multicolumn{2}{|c|}{0.5798} & \multicolumn{2}{|c|}{0.6072} & \multicolumn{2}{|c|}{0.5697} \\
\hline
\end{tabular}

j. Release 5 - Cumulative survival

\begin{tabular}{|c|c|c|c|c|c|c|c|c|c|c|c|c|c|c|c|c|c|c|}
\hline & & & & & & & & & \multicolumn{2}{|c|}{$\begin{array}{c}\text { Release to } \\
\text { CR309.0 }\end{array}$} & \multicolumn{2}{|c|}{$\begin{array}{l}\text { Release to } \\
\text { CR275.0 }\end{array}$} & \multicolumn{2}{|c|}{$\begin{array}{c}\text { Release to } \\
\text { CR234.0 }\end{array}$} & \multicolumn{2}{|c|}{$\begin{array}{c}\text { Release to } \\
\text { CR156.0 }\end{array}$} & \multicolumn{2}{|c|}{$\begin{array}{c}\text { Release to } \\
\text { CR113.0 }\end{array}$} \\
\hline & Est & SE & Est & SE & Est & $\mathrm{SE}$ & Est & SE & Est & SE & Est & SE & Est & SE & Est & SE & Est & SE \\
\hline A & & & & & & & & & 0.9931 & 0.0069 & 0.9444 & 0.0191 & 0.9446 & 0.0191 & 0.9245 & 0.0222 & 0.9097 & 0.0239 \\
\hline B & & & & & & & & & 0.9832 & 0.0118 & 0.9244 & 0.0242 & 0.9257 & 0.0243 & 0.8565 & 0.0322 & 0.8565 & 0.0322 \\
\hline C & & & & & & & & & 1.0000 & 0.0000 & 0.9187 & 0.0246 & 0.9189 & 0.0247 & 0.8943 & 0.0277 & 0.8945 & 0.0277 \\
\hline D & & & & & & & & & 0.9918 & 0.0082 & 0.9672 & 0.0161 & 0.9672 & 0.0161 & 0.9341 & 0.0225 & 0.9345 & 0.0225 \\
\hline$E$ & & & & & & & & & 0.9892 & 0.0107 & 0.9032 & 0.0307 & 0.8925 & 0.0321 & 0.8602 & 0.0360 & 0.8615 & 0.0360 \\
\hline $\mathrm{F}$ & & & & & & & & & 0.9910 & 0.0090 & 0.9459 & 0.0215 & 0.9459 & 0.0215 & 0.9110 & 0.0272 & 0.9011 & 0.0284 \\
\hline G & & & & & & & & & 1.0000 & 0.0000 & 0.9561 & 0.0192 & 0.9565 & 0.0192 & 0.9211 & 0.0253 & 0.9211 & 0.0253 \\
\hline $\mathrm{H}$ & & & & & & & & & 0.9809 & 0.0109 & 0.9427 & 0.0186 & 0.9429 & 0.0186 & 0.9115 & 0.0228 & 0.9056 & 0.0235 \\
\hline$P$-value & & & & & & & & & \multicolumn{2}{|c|}{0.8337} & \multicolumn{2}{|c|}{0.5108} & \multicolumn{2}{|c|}{0.3564} & \multicolumn{2}{|c|}{0.3386} & \multicolumn{2}{|c|}{0.4658} \\
\hline
\end{tabular}


Table A.7. (contd)

k. Release 6 - Reach survival

\begin{tabular}{|c|c|c|c|c|c|c|c|c|c|c|c|c|c|c|c|c|c|c|}
\hline & & & & & & & & & & & \multicolumn{2}{|c|}{$\begin{array}{c}\text { Release to } \\
\text { CR275.0 }\end{array}$} & \multicolumn{2}{|c|}{$\begin{array}{l}\text { CR275.0 to } \\
\text { CR234.0 }\end{array}$} & \multicolumn{2}{|c|}{$\begin{array}{c}\text { CR234.0 to } \\
\text { CR156.0 }\end{array}$} & \multicolumn{2}{|c|}{$\begin{array}{l}\text { CR156.0 to } \\
\text { CR113.0 }\end{array}$} \\
\hline & Est & SE & Est & $\mathrm{SE}$ & Est & $\mathrm{SE}$ & Est & SE & Est & $\mathrm{SE}$ & Est & $\mathrm{SE}$ & Est & SE & Est & SE & Est & SE \\
\hline$A$ & & & & & & & & & & & 1.0000 & 0.0000 & 1.0000 & 0.0000 & 0.9474 & 0.0209 & 1.0000 & 0.0000 \\
\hline B & & & & & & & & & & & 1.0000 & 0.0000 & 1.0000 & 0.0000 & 0.9780 & 0.0154 & 1.0000 & 0.0000 \\
\hline C & & & & & & & & & & & 0.9905 & 0.0095 & 0.9905 & 0.0096 & 0.9916 & 0.0099 & 0.9895 & 0.0112 \\
\hline D & & & & & & & & & & & 0.9894 & 0.0106 & 1.0002 & 0.0003 & 0.9795 & 0.0153 & 0.9879 & 0.0121 \\
\hline$E$ & & & & & & & & & & & 1.0000 & 0.0000 & 0.9753 & 0.0172 & 0.9873 & 0.0126 & 1.0000 & 0.0000 \\
\hline $\mathrm{F}$ & & & & & & & & & & & 0.9775 & 0.0157 & 0.9774 & 0.0161 & 0.9654 & 0.0203 & 0.9867 & 0.0132 \\
\hline G & & & & & & & & & & & 0.9889 & 0.0110 & 1.0000 & 0.0000 & 0.9775 & 0.0157 & 1.0000 & 0.0000 \\
\hline $\mathrm{H}$ & & & & & & & & & & & 1.0000 & 0.0000 & 0.9923 & 0.0080 & 0.9590 & 0.0179 & 1.0005 & 0.0005 \\
\hline$P$-value & & & & & & & & & & & \multicolumn{2}{|c|}{0.8550} & \multicolumn{2}{|c|}{0.6237} & \multicolumn{2}{|c|}{0.5666} & \multicolumn{2}{|c|}{0.9283} \\
\hline
\end{tabular}

1. Release 6 - Cumulative survival

\begin{tabular}{|c|c|c|c|c|c|c|c|c|c|c|c|c|c|c|c|c|c|c|}
\hline & & & & & & & & & & & \multicolumn{2}{|c|}{$\begin{array}{c}\text { Release to } \\
\text { CR275.0 }\end{array}$} & \multicolumn{2}{|c|}{$\begin{array}{c}\text { Release to } \\
\text { CR234.0 }\end{array}$} & \multicolumn{2}{|c|}{$\begin{array}{c}\text { Release to } \\
\text { CR156.0 }\end{array}$} & \multicolumn{2}{|c|}{$\begin{array}{c}\text { Release to } \\
\text { CR113.0 }\end{array}$} \\
\hline & Est & SE & Est & SE & Est & SE & Est & SE & Est & SE & Est & SE & Est & SE & Est & SE & Est & SE \\
\hline A & & & & & & & & & & & 1.0000 & 0.0000 & 1.0000 & 0.0000 & 0.9474 & 0.0209 & 0.9474 & 0.0209 \\
\hline B & & & & & & & & & & & 1.0000 & 0.0000 & 1.0000 & 0.0000 & 0.9780 & 0.0154 & 0.9780 & 0.0154 \\
\hline C & & & & & & & & & & & 0.9905 & 0.0095 & 0.9810 & 0.0133 & 0.9728 & 0.0163 & 0.9626 & 0.0187 \\
\hline D & & & & & & & & & & & 0.9894 & 0.0106 & 0.9896 & 0.0106 & 0.9693 & 0.0182 & 0.9576 & 0.0208 \\
\hline $\mathrm{E}$ & & & & & & & & & & & 1.0000 & 0.0000 & 0.9753 & 0.0172 & 0.9630 & 0.0210 & 0.9630 & 0.0210 \\
\hline $\mathrm{F}$ & & & & & & & & & & & 0.9775 & 0.0157 & 0.9555 & 0.0220 & 0.9224 & 0.0286 & 0.9101 & 0.0303 \\
\hline G & & & & & & & & & & & 0.9889 & 0.0110 & 0.9889 & 0.0110 & 0.9667 & 0.0189 & 0.9667 & 0.0189 \\
\hline $\mathrm{H}$ & & & & & & & & & & & 1.0000 & 0.0000 & 0.9923 & 0.0080 & 0.9516 & 0.0193 & 0.9520 & 0.0193 \\
\hline$P$-value & & & & & & & & & & & \multicolumn{2}{|c|}{0.8550} & \multicolumn{2}{|c|}{0.4015} & \multicolumn{2}{|c|}{0.5931} & \multicolumn{2}{|c|}{0.4837} \\
\hline
\end{tabular}


Table A.7. (contd)

m. Release 7 - Reach survival

\begin{tabular}{|c|c|c|c|c|c|c|c|c|c|c|c|c|c|c|c|c|c|c|}
\hline & & & & & & & & & & & & & \multicolumn{2}{|c|}{$\begin{array}{c}\text { Release to } \\
\text { CR234.0 }\end{array}$} & \multicolumn{2}{|c|}{$\begin{array}{c}\text { CR234.0 to } \\
\text { CR156.0 }\end{array}$} & \multicolumn{2}{|c|}{$\begin{array}{l}\text { CR156.0 to } \\
\text { CR113.0 }\end{array}$} \\
\hline & Est & SE & Est & SE & Est & SE & Est & SE & Est & SE & Est & SE & Est & SE & Est & SE & Est & SE \\
\hline$A$ & & & & & & & & & & & & & 1.0000 & 0.0000 & 0.9729 & 0.0157 & 0.9901 & 0.0099 \\
\hline B & & & & & & & & & & & & & 0.9886 & 0.0113 & 0.9770 & 0.0161 & 1.0006 & 0.0007 \\
\hline C & & & & & & & & & & & & & 1.0001 & 0.0001 & 0.9911 & 0.0099 & 0.9792 & 0.0146 \\
\hline D & & & & & & & & & & & & & 0.9607 & 0.0194 & 0.9700 & 0.0178 & 0.9881 & 0.0118 \\
\hline$E$ & & & & & & & & & & & & & 1.0000 & 0.0000 & 0.9872 & 0.0127 & 1.0000 & 0.0000 \\
\hline$F$ & & & & & & & & & & & & & 0.9891 & 0.0111 & 0.9773 & 0.0159 & 1.0001 & 0.0002 \\
\hline G & & & & & & & & & & & & & 1.0000 & 0.0000 & 0.9667 & 0.0189 & 1.0000 & 0.0000 \\
\hline $\mathrm{H}$ & & & & & & & & & & & & & 1.0010 & 0.0007 & 0.9597 & 0.0177 & 1.0000 & 0.0000 \\
\hline$P$-value & & & & & & & & & & & & & \multicolumn{2}{|c|}{0.1548} & \multicolumn{2}{|c|}{0.8860} & \multicolumn{2}{|c|}{0.6569} \\
\hline
\end{tabular}

n. Release 7 - Cumulative survival

\begin{tabular}{|c|c|c|c|c|c|c|c|c|c|c|c|c|c|c|c|c|c|c|}
\hline & & & & & & & & & & & & & \multicolumn{2}{|c|}{$\begin{array}{c}\text { Release to } \\
\text { CR234.0 }\end{array}$} & \multicolumn{2}{|c|}{$\begin{array}{c}\text { Release to } \\
\text { CR156.0 }\end{array}$} & \multicolumn{2}{|c|}{$\begin{array}{c}\text { Release to } \\
\text { CR113.0 }\end{array}$} \\
\hline & Est & SE & Est & SE & Est & SE & Est & SE & Est & SE & Est & SE & Est & SE & Est & SE & Est & SE \\
\hline A & & & & & & & & & & & & & 1.0000 & 0.0000 & 0.9729 & 0.0157 & 0.9633 & 0.0180 \\
\hline B & & & & & & & & & & & & & 0.9886 & 0.0113 & 0.9659 & 0.0193 & 0.9665 & 0.0194 \\
\hline C & & & & & & & & & & & & & 1.0001 & 0.0001 & 0.9912 & 0.0098 & 0.9706 & 0.0167 \\
\hline D & & & & & & & & & & & & & 0.9607 & 0.0194 & 0.9319 & 0.0253 & 0.9208 & 0.0269 \\
\hline$E$ & & & & & & & & & & & & & 1.0000 & 0.0000 & 0.9872 & 0.0127 & 0.9872 & 0.0127 \\
\hline $\mathrm{F}$ & & & & & & & & & & & & & 0.9891 & 0.0111 & 0.9667 & 0.0189 & 0.9668 & 0.0189 \\
\hline G & & & & & & & & & & & & & 1.0000 & 0.0000 & 0.9667 & 0.0189 & 0.9667 & 0.0189 \\
\hline $\mathrm{H}$ & & & & & & & & & & & & & 1.0010 & 0.0007 & 0.9606 & 0.0173 & 0.9606 & 0.0173 \\
\hline$P$-value & & & & & & & & & & & & & \multicolumn{2}{|c|}{0.1548} & \multicolumn{2}{|c|}{0.4022} & \multicolumn{2}{|c|}{0.4429} \\
\hline
\end{tabular}


Table A.7. (contd)

o. Release 8 - Reach survival

\begin{tabular}{|c|c|c|c|c|c|c|c|c|c|c|c|c|c|c|c|c|c|c|}
\hline & & & & & & & & & & & & & & & \multicolumn{2}{|c|}{$\begin{array}{l}\text { Release to } \\
\text { CR156.0 }\end{array}$} & \multicolumn{2}{|c|}{$\begin{array}{l}\text { CR156.0 to } \\
\text { CR113.0 }\end{array}$} \\
\hline & Est & SE & Est & SE & Est & SE & Est & SE & Est & SE & Est & SE & Est & SE & Est & SE & Est & SE \\
\hline$A$ & & & & & & & & & & & & & & & 0.9938 & 0.0049 & 0.9889 & 0.0064 \\
\hline B & & & & & & & & & & & & & & & 1.0004 & 0.0004 & 0.9954 & 0.0046 \\
\hline C & & & & & & & & & & & & & & & 0.9885 & 0.0066 & 1.0000 & 0.0000 \\
\hline D & & & & & & & & & & & & & & & 0.9967 & 0.0042 & 0.9867 & 0.0076 \\
\hline $\mathrm{E}$ & & & & & & & & & & & & & & & 0.9901 & 0.0069 & 1.0002 & 0.0002 \\
\hline $\mathrm{F}$ & & & & & & & & & & & & & & & 0.9912 & 0.0062 & 1.0001 & 0.0001 \\
\hline G & & & & & & & & & & & & & & & 0.9959 & 0.0045 & 0.9952 & 0.0048 \\
\hline H & & & & & & & & & & & & & & & 0.9908 & 0.0055 & 0.9966 & 0.0036 \\
\hline$P$-value & & & & & & & & & & & & & & & 0.7 & & & 38 \\
\hline
\end{tabular}

p. Release 8 - Cumulative survival

\begin{tabular}{|c|c|c|c|c|c|c|c|c|c|c|c|c|c|c|c|c|c|c|}
\hline & & & & & & & & & & & & & & & \multicolumn{2}{|c|}{$\begin{array}{c}\text { Release to } \\
\text { CR156.0 }\end{array}$} & \multicolumn{2}{|c|}{$\begin{array}{c}\text { Release to } \\
\text { CR113.0 }\end{array}$} \\
\hline & Est & SE & Est & SE & Est & SE & Est & SE & Est & $\mathrm{SE}$ & Est & SE & Est & SE & Est & SE & Est & SE \\
\hline A & & & & & & & & & & & & & & & 0.9938 & 0.0049 & 0.9828 & 0.0077 \\
\hline B & & & & & & & & & & & & & & & 1.0004 & 0.0004 & 0.9957 & 0.0042 \\
\hline C & & & & & & & & & & & & & & & 0.9885 & 0.0066 & 0.9885 & 0.0066 \\
\hline D & & & & & & & & & & & & & & & 0.9967 & 0.0042 & 0.9835 & 0.0082 \\
\hline$E$ & & & & & & & & & & & & & & & 0.9901 & 0.0069 & 0.9903 & 0.0069 \\
\hline$F$ & & & & & & & & & & & & & & & 0.9912 & 0.0062 & 0.9913 & 0.0062 \\
\hline G & & & & & & & & & & & & & & & 0.9959 & 0.0045 & 0.9911 & 0.0063 \\
\hline $\mathrm{H}$ & & & & & & & & & & & & & & & 0.9908 & 0.0055 & 0.9875 & 0.0063 \\
\hline$P$-value & & & & & & & & & & & & & & & 0.7 & 21 & & \\
\hline
\end{tabular}


Table A.7. (contd)

q. Release 9-Reach survival

\begin{tabular}{|c|c|c|c|c|c|c|c|c|c|c|c|c|c|c|c|c|c|c|}
\hline & & & & & & & & & & & & & & & & & \multicolumn{2}{|c|}{$\begin{array}{c}\text { Release to } \\
\text { CR113.0 }\end{array}$} \\
\hline & Est & $\mathrm{SE}$ & Est & SE & Est & $\mathrm{SE}$ & Est & SE & Est & SE & Est & $\mathrm{SE}$ & Est & $\mathrm{SE}$ & Est & $\mathrm{SE}$ & Est & $\mathrm{SE}$ \\
\hline A & & & & & & & & & & & & & & & & & 1.0000 & 0.0000 \\
\hline B & & & & & & & & & & & & & & & & & 1.0001 & 0.0001 \\
\hline C & & & & & & & & & & & & & & & & & 1.0003 & 0.0003 \\
\hline D & & & & & & & & & & & & & & & & & 1.0000 & 0.0000 \\
\hline $\mathrm{E}$ & & & & & & & & & & & & & & & & & 0.9900 & 0.0071 \\
\hline $\mathrm{F}$ & & & & & & & & & & & & & & & & & 0.9914 & 0.0060 \\
\hline G & & & & & & & & & & & & & & & & & 1.0000 & 0.0000 \\
\hline $\mathrm{H}$ & & & & & & & & & & & & & & & & & 1.0001 & 0.0001 \\
\hline$P$-value & & & & & & & & & & & & & & & & & & 604 \\
\hline
\end{tabular}

$\underset{+}{i} \quad$ r. Release 9 - Cumulative survival

\begin{tabular}{|c|c|c|c|c|c|c|c|c|c|c|c|c|c|c|c|c|c|c|}
\hline & & & & & & & & & & & & & & & & & \multicolumn{2}{|c|}{$\begin{array}{c}\text { Release to } \\
\text { CR113.0 }\end{array}$} \\
\hline & Est & SE & Est & $\mathrm{SE}$ & Est & $\mathrm{SE}$ & Est & SE & Est & $\mathrm{SE}$ & Est & $\mathrm{SE}$ & Est & $\mathrm{SE}$ & Est & $\mathrm{SE}$ & Est & SE \\
\hline A & & & & & & & & & & & & & & & & & 1.0000 & 0.0000 \\
\hline B & & & & & & & & & & & & & & & & & 1.0001 & 0.0001 \\
\hline c & & & & & & & & & & & & & & & & & 1.0003 & 0.0003 \\
\hline D & & & & & & & & & & & & & & & & & 1.0000 & 0.0000 \\
\hline $\mathrm{E}$ & & & & & & & & & & & & & & & & & 0.9900 & 0.0071 \\
\hline $\mathrm{F}$ & & & & & & & & & & & & & & & & & 0.9914 & 0.0060 \\
\hline G & & & & & & & & & & & & & & & & & 1.0000 & 0.0000 \\
\hline $\mathrm{H}$ & & & & & & & & & & & & & & & & & 1.0001 & 0.0001 \\
\hline$P$-value & & & & & & & & & & & & & & & & & 0.3 & \\
\hline
\end{tabular}




\section{A.2 Examination of Delayed Handling Effects}

\section{A.2.1 Spring Study}

The purpose of these tests was to assess whether downstream reach survivals were affected by how far upstream yearling and subyearling Chinook salmon and juvenile steelhead were released. Results were used to determine which release groups were used in the construction of virtual-release groups at John Day Dam.

One of the 10 tests (i.e., 10\%) of the reach survival comparisons was significant at $\alpha=0.10$ (Table A.8). In many instances, upriver releases of fish had equal or higher survival than fish released further downriver. Comparisons of cumulative survivals in reaches common to multiple release groups found 1 of 18 tests significant at $\alpha=0.10$ (i.e., 5.6\%) (Table A.9). Once again, there was no relationship between time in-river and cumulative downriver survival.

Consequently, no evidence was found in the spring studies that would indicate delayed handling/tag effects. Therefore, fish from releases $R_{1}, \ldots, R_{3}$ were used in forming the virtual-release group at John Day Dam. 
Table A.8. Comparison of reach survivals between tag releases from different upstream locations for a) yearling Chinook salmon and b) steelhead during the 2012 spring JSATS survival study in the Columbia River. Newly released and previously released fish were not compared within a reach (shaded).

a. Yearling Chinook salmon

\begin{tabular}{|c|c|c|c|c|c|c|c|c|c|c|c|}
\hline \multirow[b]{2}{*}{ Reach } & \multicolumn{2}{|c|}{ CR503 } & \multicolumn{2}{|c|}{ CR468 } & \multicolumn{2}{|c|}{ CR422 } & \multicolumn{2}{|c|}{ CR346 } & \multicolumn{2}{|c|}{ CR325 } & \multirow[b]{2}{*}{$P$ (F-test) } \\
\hline & Est & SE & Est & SE & Est & SE & Est & SE & Est & SE & \\
\hline Release to CR422 & 0.9060 & 0.0085 & 0.9288 & 0.0082 & & & & & & & \\
\hline CR422 to CR349 & 0.9506 & 0.0063 & 0.9743 & 0.0052 & 0.9498 & 0.0070 & & & & & 0.0037 \\
\hline CR349 to CR325 & 0.9712 & 0.0049 & 0.9568 & 0.0063 & 0.9582 & 0.0060 & 1.0004 & 0.0024 & & & 0.1500 \\
\hline CR325 to CR309 & 0.9911 & 0.0029 & 0.9908 & 0.0031 & 0.9894 & 0.0032 & 0.9844 & 0.0040 & 0.9896 & 0.0041 & 0.4547 \\
\hline CR309 to CR234 & 0.9357 & 0.0076 & 0.9434 & 0.0075 & 0.9414 & 0.0074 & 0.9474 & 0.0074 & 0.9313 & 0.0083 & 0.5960 \\
\hline CR234 to CR156 ( $\lambda)$ & 0.9271 & 0.0083 & 0.9367 & 0.0080 & 0.9274 & 0.0084 & 0.9530 & 0.0071 & 0.9369 & 0.0082 & 0.1412 \\
\hline
\end{tabular}

b. Steelhead

\begin{tabular}{|c|c|c|c|c|c|c|c|c|c|c|c|}
\hline \multirow[b]{2}{*}{ Reach } & \multicolumn{2}{|c|}{ CR503 } & \multicolumn{2}{|c|}{ CR468 } & \multicolumn{2}{|c|}{ CR422 } & \multicolumn{2}{|c|}{ CR346 } & \multicolumn{2}{|c|}{ CR325 } & \multirow[b]{2}{*}{$P($ F-test $)$} \\
\hline & Est & SE & Est & SE & Est & SE & Est & SE & Est & SE & \\
\hline Release to CR422 & 0.8521 & 0.0095 & 0.9149 & 0.0081 & & & & & & & \\
\hline CR422 to CR349 & 0.9489 & 0.0064 & 0.9335 & 0.0075 & 0.9366 & 0.0070 & & & & & 0.1183 \\
\hline CR349 to CR325 & 0.9724 & 0.0049 & 0.9783 & 0.0046 & 0.9685 & 0.0052 & 0.9860 & 0.0037 & & & 0.3637 \\
\hline CR325 to CR309 & 0.9984 & 0.0013 & 0.9950 & 0.0022 & 0.9926 & 0.0026 & 0.9940 & 0.0025 & 0.9751 & 0.0049 & 0.2897 \\
\hline CR309 to CR234 & 0.9574 & 0.0063 & 0.9523 & 0.0069 & 0.9645 & 0.0058 & 0.9599 & 0.0064 & 0.9459 & 0.0074 & 0.3157 \\
\hline CR234 to CR156 ( $\lambda)$ & 0.9054 & 0.0092 & 0.9107 & 0.0094 & 0.9124 & 0.0089 & 0.9300 & 0.0084 & 0.9237 & 0.0088 & 0.2778 \\
\hline
\end{tabular}


Table A.9. Comparison of cumulative survivals between tag releases from different upstream locations for a) yearling Chinook salmon and b) steelhead during the 2012 spring JSATS survival study in the Columbia River.

a. Yearling Chinook salmon

\begin{tabular}{|c|c|c|c|c|c|c|c|c|c|}
\hline \multirow[b]{2}{*}{ Reach } & \multicolumn{2}{|c|}{ CR503 } & \multicolumn{2}{|c|}{ CR468 } & \multirow[b]{2}{*}{$P(F$-test $)$} & & & & \\
\hline & Est & SE & Est & SE & & & & & \\
\hline CR422 to CR349 & 0.9506 & 0.0063 & 0.9743 & 0.0051 & 0.0035 & & & & \\
\hline CR422 to CR325 & 0.9232 & 0.0078 & 0.9322 & 0.0078 & 0.4146 & & & & \\
\hline CR422 to CR309 & 0.9149 & 0.0082 & 0.9236 & 0.0083 & 0.4559 & & & & \\
\hline \multirow[t]{2}{*}{ CR422 to CR234 } & 0.8561 & 0.0104 & 0.8714 & 0.0105 & 0.3005 & & & & \\
\hline & \multicolumn{2}{|c|}{ CR503 } & \multicolumn{2}{|c|}{ CR468 } & \multicolumn{2}{|c|}{ CR422 } & & & \\
\hline Reach & Est & SE & Est & SE & Est & SE & $P(F$-test $)$ & & \\
\hline CR349 to CR325 & 0.9712 & 0.0049 & 0.9568 & 0.0063 & 0.9581 & 0.0060 & 0.1482 & & \\
\hline CR349 to CR309 & 0.9625 & 0.0056 & 0.9480 & 0.0069 & 0.9480 & 0.0067 & 0.1831 & & \\
\hline \multirow[t]{2}{*}{ CR349 to CR234 } & 0.9005 & 0.0090 & 0.8943 & 0.0096 & 0.8925 & 0.0095 & 0.8182 & & \\
\hline & \multicolumn{2}{|c|}{ CR503 } & \multicolumn{2}{|c|}{ CR468 } & \multicolumn{2}{|c|}{ CR422 } & \multicolumn{2}{|c|}{ CR346 } & \\
\hline Reach & Est & SE & Est & SE & Est & SE & Est & SE & $P(F$-test $)$ \\
\hline CR325 to CR309 & 0.9911 & 0.0029 & 0.9908 & 0.0031 & 0.9894 & 0.0032 & 0.9844 & 0.0040 & 0.4547 \\
\hline CR325 to CR234 & 0.9273 & 0.0080 & 0.9346 & 0.0079 & 0.9315 & 0.0079 & 0.9325 & 0.0082 & 0.9316 \\
\hline
\end{tabular}

b. Steelhead

\begin{tabular}{|c|c|c|c|c|c|c|c|c|c|}
\hline \multirow[b]{2}{*}{ Reach } & \multicolumn{2}{|c|}{ CR503 } & \multicolumn{2}{|c|}{ CR468 } & \multirow[b]{2}{*}{$P$ (F-test) } & & & & \\
\hline & Est & SE & Est & SE & & & & & \\
\hline CR422 to CR349 & 0.9489 & 0.0064 & 0.9335 & 0.0075 & 0.1183 & & & & \\
\hline CR422 to CR325 & 0.9235 & 0.0077 & 0.9132 & 0.0085 & 0.3692 & & & & \\
\hline CR422 to CR309 & 0.9220 & 0.0078 & 0.9087 & 0.0087 & 0.2550 & & & & \\
\hline \multirow[t]{2}{*}{ CR422 to CR234 } & 0.8827 & 0.0095 & 0.8654 & 0.0104 & 0.2194 & & & & \\
\hline & \multicolumn{2}{|c|}{ CR503 } & \multicolumn{2}{|c|}{ CR468 } & \multicolumn{2}{|c|}{ CR422 } & & & \\
\hline Reach & Est & SE & Est & SE & Est & SE & $P(F$-test $)$ & & \\
\hline CR349 to CR325 & 0.9724 & 0.0049 & 0.9783 & 0.0046 & 0.9685 & 0.0052 & 0.3637 & & \\
\hline CR349 to CR309 & 0.9708 & 0.0050 & 0.9735 & 0.0051 & 0.9613 & 0.0058 & 0.2333 & & \\
\hline \multirow[t]{2}{*}{ CR349 to CR234 } & 0.9303 & 0.0078 & 0.9271 & 0.0083 & 0.9272 & 0.0079 & 0.9496 & & \\
\hline & \multicolumn{2}{|c|}{ CR503 } & \multicolumn{2}{|c|}{ CR468 } & \multicolumn{2}{|c|}{ CR422 } & \multicolumn{2}{|c|}{ CR346 } & \\
\hline Reach & Est & SE & Est & SE & Est & SE & Est & SE & $P(F$-test $)$ \\
\hline CR325 to CR309 & 0.9983 & 0.0013 & 0.9950 & 0.0022 & 0.9926 & 0.0026 & 0.9940 & 0.0025 & 0.3065 \\
\hline CR325 to CR234 & 0.9567 & 0.0064 & 0.9475 & 0.0072 & 0.9574 & 0.0063 & 0.9541 & 0.0067 & 0.7108 \\
\hline
\end{tabular}




\section{A.2.2 Summer Study}

Both the tests of homogeneous reach survival and cumulative survivals were significant in the last four or so reaches (Table A.10 and Table A.11). Further examination of the cumulative survivals indicated release groups $R_{1}, R_{2}$, and $R_{3}$ had depressed survivals in the reach CR325 and below. $P$-values for tests of homogeneous cumulative survival became nonsignificant when these release groups were omitted from analyses below CR325 (Table A.11).

Releases $R_{1}-R_{3}$ were used in the analyses conducted at McNary, John Day, and The Dalles dams but not in the Bonneville Dam survival analysis or for the associated Fish Accords at that dam. No other release groups required omission in forming virtual-release groups (i.e., $V_{1}$ ) at the other three dams. 
Table A.10. Comparison of reach survivals between tag releases from different upstream locations for subyearling Chinook salmon during the summer 2012 JSATS survival study in the Columbia River. Newly released and previously released fish were not compared within a reach (shaded).

\begin{tabular}{|c|c|c|c|c|c|c|c|c|c|c|c|c|c|c|c|c|c|c|c|}
\hline & CR503 & & CR468 & & CR422 & & CR346 & & CR325 & & CR307 & & CR275 & & CR233 & & CR156 & & \\
\hline Reach & Est & SE & Est & SE & Est & SE & Est & SE & Est & SE & Est & SE & Est & SE & Est & SE & Est & SE & $\mathrm{P}$ (F-test) \\
\hline Release to CR470 & 0.9803 & 0.0030 & & & & & & & & & & & & & & & & & \\
\hline CR470 to CR422 & 0.9147 & 0.0057 & 0.9274 & 0.0063 & & & & & & & & & & & & & & & \\
\hline CR422 to CR349 & 0.9556 & 0.0044 & 0.9558 & 0.0050 & 0.9443 & 0.0060 & & & & & & & & & & & & & 0.9760 \\
\hline CR349 to CR325 & 0.9367 & 0.0053 & 0.9437 & 0.0055 & 0.9408 & 0.0055 & 1.0005 & 0.0014 & & & & & & & & & & & 0.6578 \\
\hline CR325 to CR309 & 0.9918 & 0.0020 & 0.9894 & 0.0026 & 0.9905 & 0.0024 & 0.9962 & 0.0020 & 0.9925 & 0.0034 & & & & & & & & & 0.1576 \\
\hline CR309 to CR275 & 0.9500 & 0.0049 & 0.9414 & 0.0058 & 0.9318 & 0.0061 & 0.9382 & 0.0077 & 0.9480 & 0.0071 & 0.9952 & 0.0031 & & & & & & & 0.2535 \\
\hline CR275 to CR234 & 0.9911 & 0.0022 & 0.9875 & 0.0029 & 0.9868 & 0.0029 & 0.9908 & 0.0033 & 0.9996 & 0.0012 & 0.9929 & 0.0031 & 0.9944 & 0.0036 & & & & & 0.0121 \\
\hline CR234 to CR156 & 0.9518 & 0.0052 & 0.9593 & 0.0053 & 0.9606 & 0.0050 & 0.9670 & 0.0061 & 0.9639 & 0.0063 & 0.9725 & 0.0060 & 0.9753 & 0.0058 & 0.9992 & 0.0069 & & & 0.0606 \\
\hline CR156 to CR113 & 0.9900 & 0.0028 & 0.9842 & 0.0036 & 0.9889 & 0.0029 & 0.9942 & 0.0028 & 0.9958 & 0.0025 & 0.9962 & 0.0025 & 0.9947 & 0.0029 & 0.9962 & 0.0020 & 1.0037 & 0.0052 & 0.0155 \\
\hline CR113 to CR86 ( $\lambda)$ & 0.9855 & 0.0030 & 0.9923 & 0.0024 & 0.9926 & 0.0023 & 0.9955 & 0.0024 & 0.9885 & 0.0037 & 0.9933 & 0.0031 & 0.9975 & 0.0019 & 0.9970 & 0.0014 & 0.9991 & 0.0009 & 0.0015 \\
\hline
\end{tabular}


Table A.11. Comparison of cumulative survivals between tag releases from different upstream locations for subyearling Chinook salmon during the 2012 summer JSATS survival study in the Columbia River. $P$-values for tests of homogeneity were computed using all release groups, omitting release $R_{1}$, omitting releases $R_{1}$ and $R_{2}$, or omitting releases $R_{1}, R_{2}$, and $R_{3}$.

\begin{tabular}{cccccc}
\hline & \multicolumn{2}{c}{ CR503 (R1) } & \multicolumn{2}{c}{ CR468 (R2) } & \\
\cline { 2 - 5 } Reach & Est & SE & Est & SE & $P$ \\
\hline CR422 to CR349 & 0.9556 & 0.0048 & 0.9558 & 0.0050 & 0.9770 \\
CR422 to CR325 & 0.8952 & 0.0069 & 0.9019 & 0.0071 & 0.4986 \\
CR422 to CR309 & 0.8878 & 0.0072 & 0.8924 & 0.0074 & 0.6559 \\
CR422 to CR275 & 0.8434 & 0.0082 & 0.8401 & 0.0087 & 0.7825 \\
CR422 to CR234 & 0.8359 & 0.0086 & 0.8296 & 0.0090 & 0.6128 \\
CR422 to CR156 & 0.7956 & 0.0095 & 0.7958 & 0.0097 & 0.9882 \\
CR422 to CR113 & 0.7877 & 0.0098 & 0.7833 & 0.0099 & 0.7521 \\
\hline
\end{tabular}

\begin{tabular}{cccccccccc}
\hline & \multicolumn{1}{c}{ CR503 (R1) } & \multicolumn{2}{c}{ CR468 (R2) } & \multicolumn{2}{c}{ CR422 (R3) } & & \\
\cline { 2 - 7 } Reach & Est & SE & Est & SE & Est & SE & $P$ & $P$-r1 \\
\hline CR349 to CR325 & 0.9367 & 0.0053 & 0.9437 & 0.0055 & 0.9413 & 0.0055 & 0.6515 & 0.7577 \\
CR349 to CR309 & 0.9290 & 0.0056 & 0.9337 & 0.0060 & 0.9323 & 0.0060 & 0.8445 & 0.8690 \\
CR349 to CR275 & 0.8826 & 0.0070 & 0.8789 & 0.0078 & 0.8687 & 0.0081 & 0.4123 & 0.3644 \\
CR349 to CR234 & 0.8747 & 0.0073 & 0.8680 & 0.0082 & 0.8573 & 0.0086 & 0.3048 & 0.3679 \\
CR349 to CR156 & 0.8326 & 0.0084 & 0.8327 & 0.0091 & 0.8234 & 0.0098 & 0.7096 & 0.4868 \\
CR349 to CR113 & 0.8243 & 0.0086 & 0.8195 & 0.0093 & 0.8143 & 0.0102 & 0.7530 & 0.7064 \\
\hline
\end{tabular}

\begin{tabular}{|c|c|c|c|c|c|c|c|c|c|c|c|}
\hline \multirow[b]{2}{*}{ Reach } & \multicolumn{2}{|c|}{ CR503 (R1) } & \multicolumn{2}{|c|}{ CR468 (R2) } & \multicolumn{2}{|c|}{ CR422 (R3) } & \multicolumn{2}{|c|}{ CR346 (R4) } & \multirow[b]{2}{*}{$P$} & \multirow[b]{2}{*}{$P$-r1 } & \multirow[b]{2}{*}{$P-\mathrm{r} 1 \mathrm{r} 2$} \\
\hline & Est & SE & Est & SE & Est & SE & Est & SE & & & \\
\hline CR325 to CR309 & 0.9918 & 0.0020 & 0.9894 & 0.0026 & 0.9905 & 0.0024 & 0.9962 & 0.0020 & 0.1576 & 0.0890 & 0.0681 \\
\hline CR325 to CR275 & 0.9422 & 0.0052 & 0.9314 & 0.0063 & 0.9230 & 0.0065 & 0.9346 & 0.0079 & 0.2191 & 0.4743 & 0.2568 \\
\hline CR325 to CR234 & 0.9338 & 0.0056 & 0.9197 & 0.0070 & 0.9108 & 0.0071 & 0.9259 & 0.0084 & 0.1304 & 0.3617 & 0.1698 \\
\hline CR325 to CR156 & 0.8888 & 0.0072 & 0.8823 & 0.0085 & 0.8749 & 0.0084 & 0.8954 & 0.0099 & 0.3672 & 0.2612 & 0.1144 \\
\hline CR325 to CR113 & 0.8799 & 0.0075 & 0.8684 & 0.0090 & 0.8652 & 0.0088 & 0.8902 & 0.0101 & 0.1761 & 0.1186 & 0.0620 \\
\hline
\end{tabular}

\begin{tabular}{|c|c|c|c|c|c|c|c|c|c|c|c|c|c|c|}
\hline \multirow[b]{2}{*}{ Reach } & \multicolumn{2}{|c|}{ CR503 (R1) } & \multicolumn{2}{|c|}{ CR468 (R2) } & \multicolumn{2}{|c|}{ CR422 (R3) } & \multicolumn{2}{|c|}{ CR346 (R4) } & \multicolumn{2}{|c|}{ CR325 (R5) } & \multirow[b]{2}{*}{$P$} & \multirow[b]{2}{*}{$P-\mathrm{r} 1$} & \multirow[b]{2}{*}{$P$-r1r2 } & \multirow[b]{2}{*}{$P-r 1 r 2 r 3$} \\
\hline & Est & SE & Est & SE & Est & SE & Est & SE & Est & SE & & & & \\
\hline CR309 to CR275 & 0.9500 & 0.0049 & 0.9414 & 0.0059 & 0.9318 & 0.0061 & 0.9382 & 0.0077 & 0.9480 & 0.0072 & 0.2597 & 0.3950 & 0.2602 & 0.3526 \\
\hline CR309 to CR234 & 0.9416 & 0.0054 & 0.9296 & 0.0065 & 0.9195 & 0.0066 & 0.9295 & 0.0083 & 0.9476 & 0.0074 & 0.0356 & 0.0493 & 0.0263 & 0.1036 \\
\hline CR309 to CR156 & 0.8962 & 0.0072 & 0.8917 & 0.0081 & 0.8832 & 0.0079 & 0.8989 & 0.0100 & 0.9133 & 0.0097 & 0.1633 & 0.1089 & 0.0706 & 0.3013 \\
\hline CR309 to CR113 & 0.8873 & 0.0076 & 0.8776 & 0.0085 & 0.8735 & 0.0082 & 0.8936 & 0.0103 & 0.9095 & 0.0102 & 0.0410 & 0.0258 & 0.0296 & 0.2727 \\
\hline
\end{tabular}


Table A.11. (contd)

\begin{tabular}{|c|c|c|c|c|c|c|c|c|c|c|c|c|c|c|c|c|}
\hline \multirow[b]{2}{*}{ Reach } & \multicolumn{2}{|c|}{ CR503 (R1) } & \multicolumn{2}{|c|}{ CR468 (R2) } & \multicolumn{2}{|c|}{ CR422 (R3) } & \multicolumn{2}{|c|}{ CR346 (R4) } & \multicolumn{2}{|c|}{ CR325 (R5) } & \multicolumn{2}{|c|}{ CR307 (R6) } & \multirow[b]{2}{*}{$P$} & \multirow[b]{2}{*}{$P-\mathrm{r} 1$} & \multirow[b]{2}{*}{$P-\mathrm{r} 1 \mathrm{r} 2$} & \multirow[b]{2}{*}{$P-\mathrm{r} 1 \mathrm{r} 2 \mathrm{r} 3$} \\
\hline & Est & SE & Est & SE & Est & SE & Est & SE & Est & SE & Est & $\mathrm{SE}$ & & & & \\
\hline CR275 to CR234 & 0.9911 & 0.0023 & 0.9875 & 0.0030 & 0.9868 & 0.0029 & 0.9908 & 0.0033 & 0.9996 & 0.0012 & 0.9929 & 0.0031 & 0.0139 & 0.0091 & 0.0101 & 0.0557 \\
\hline CR275 to CR156 & 0.9434 & 0.0058 & 0.9474 & 0.0060 & 0.9479 & 0.0057 & 0.9581 & 0.0068 & 0.9635 & 0.0064 & 0.9656 & 0.0067 & 0.0490 & 0.1229 & 0.2070 & 0.7118 \\
\hline CR275 to CR113 & 0.9339 & 0.0063 & 0.9324 & 0.0067 & 0.9374 & 0.0062 & 0.9525 & 0.0072 & 0.9594 & 0.0068 & 0.9619 & 0.0070 & 0.0015 & 0.0045 & 0.0494 & 0.6166 \\
\hline
\end{tabular}

\begin{tabular}{|c|c|c|c|c|c|c|c|c|c|c|c|c|c|c|c|c|c|c|c|c|}
\hline \multirow[b]{2}{*}{ Reach } & \multicolumn{2}{|c|}{ CR503 (R1) } & \multicolumn{2}{|c|}{ CR468 (R2) } & \multicolumn{2}{|c|}{ CR422 (R3) } & \multicolumn{2}{|c|}{ CR346 (R4) } & \multicolumn{2}{|c|}{ CR325 (R5) } & \multicolumn{2}{|c|}{ CR307 (R6) } & \multicolumn{2}{|c|}{ CR275 (R7) } & \multirow[b]{2}{*}{$P$} & \multirow[b]{2}{*}{$P-\mathrm{r} 1$} & \multirow[b]{2}{*}{$P-\mathrm{r} 1 \mathrm{r} 2$} & \multirow[b]{2}{*}{$P$-r1r2r3 } & & \\
\hline & Est & SE & Est & SE & Est & SE & Est & SE & Est & SE & Est & SE & Est & SE & & & & & & \\
\hline CR234 to CR156 & 0.9518 & 0.0052 & 0.9594 & 0.0053 & 0.9606 & 0.0050 & 0.9671 & 0.0061 & 0.9639 & 0.0063 & 0.9725 & 0.0061 & 0.9753 & 0.0058 & 0.0623 & 0.2921 & 0.3769 & 0.5409 & & \\
\hline \multirow[t]{2}{*}{ CR234 to CR113 } & 0.9423 & 0.0057 & 0.9442 & 0.0060 & 0.9499 & 0.0056 & 0.9614 & 0.0066 & 0.9597 & 0.0066 & 0.9689 & 0.0065 & 0.9700 & 0.0064 & 0.0029 & 0.0207 & 0.1625 & 0.5917 & & \\
\hline & \multicolumn{2}{|c|}{ CR503 (R1) } & \multicolumn{2}{|c|}{ CR468 (R2) } & \multicolumn{2}{|c|}{ CR422 (R3) } & \multicolumn{2}{|c|}{ CR346 (R4) } & \multicolumn{2}{|c|}{ CR325 (R5) } & \multicolumn{2}{|c|}{ CR307 (R6) } & \multicolumn{2}{|c|}{ CR275 (R7) } & \multicolumn{2}{|c|}{ CR233 (R8) } & & & & \\
\hline Reach & Est & SE & Est & $\mathrm{SE}$ & Est & $\mathrm{SE}$ & Est & $\mathrm{SE}$ & Est & $\mathrm{SE}$ & Est & $\mathrm{SE}$ & Est & $\mathrm{SE}$ & Est & $\mathrm{SE}$ & $P$ & $P-r 1$ & $P-\mathrm{r} 1 \mathrm{r} 2$ & $P-\mathrm{r} 1 \mathrm{r} 2 \mathrm{r} 3$ \\
\hline CR156 to CR113 & 0.9902 & 0.0028 & 0.9841 & 0.0035 & 0.9889 & 0.0030 & 0.9942 & 0.0028 & 0.9957 & 0.0025 & 0.9963 & 0.0026 & 0.9947 & 0.0029 & 0.9961 & 0.0020 & 0.0161 & 0.0116 & 0.3612 & 0.9736 \\
\hline
\end{tabular}




\section{Appendix B}

Capture Histories Used in Estimating Dam Passage Survival 


\section{Appendix B}

\section{Capture Histories Used in Estimating Dam Passage Survival}

\section{B.1 Yearling Chinook Salmon}

\begin{tabular}{ccc}
\hline & \multicolumn{2}{c}{ V1 (Season-Wide) } \\
\cline { 2 - 3 } Capture & $\begin{array}{c}\text { Dam Passage } \\
\text { History }\end{array}$ & $\begin{array}{c}\text { BRZ-to-BRZ } \\
\text { Survival }\end{array}$ \\
\hline 111 & 2953 & 2953 \\
011 & 1 & 2 \\
101 & 4 & 4 \\
001 & 0 & 0 \\
120 & 0 & 0 \\
020 & 0 & 0 \\
110 & 257 & 257 \\
010 & 0 & 0 \\
200 & 0 & 0 \\
100 & 33 & 33 \\
000 & 128 & 133 \\
\hline Total & 3376 & 3382 \\
\hline & & \\
\hline & & \\
Capture & Season-Wide Dam Passage Survival \\
History & R2 & \\
\hline 11 & 907 & 898 \\
01 & 0 & 0 \\
20 & 0 & 83 \\
10 & 71 & 14 \\
00 & 19 & 995 \\
\hline Total & 997 &
\end{tabular}




\section{B.2 Steelhead}

\begin{tabular}{|c|c|c|}
\hline \multirow[b]{2}{*}{$\begin{array}{l}\text { Capture } \\
\text { History }\end{array}$} & \multicolumn{2}{|c|}{ V1 (Season-Wide) } \\
\hline & $\begin{array}{c}\text { Dam Passage } \\
\text { Survival }\end{array}$ & $\begin{array}{c}\text { BRZ-to-BRZ } \\
\text { Survival }\end{array}$ \\
\hline 111 & 2931 & 2932 \\
\hline 011 & 1 & 1 \\
\hline 101 & 5 & 5 \\
\hline 001 & 0 & 0 \\
\hline 120 & 0 & 0 \\
\hline 020 & 0 & 0 \\
\hline 110 & 204 & 204 \\
\hline 010 & 0 & 1 \\
\hline 200 & 0 & 0 \\
\hline 100 & 15 & 15 \\
\hline 000 & 83 & 102 \\
\hline \multirow[t]{2}{*}{ Total } & 3239 & 3260 \\
\hline & \multicolumn{2}{|c|}{ Season-Wide Dam Passage Survival } \\
\hline $\begin{array}{l}\text { Capture } \\
\text { History }\end{array}$ & $\mathrm{R} 2$ & R3 \\
\hline 11 & 928 & 902 \\
\hline 01 & 1 & 2 \\
\hline 20 & 0 & 0 \\
\hline 10 & 49 & 71 \\
\hline 00 & 22 & 25 \\
\hline Total & 1000 & 1000 \\
\hline
\end{tabular}




\section{B.3 Subyearling Chinook Salmon}

\begin{tabular}{ccc}
\hline & \multicolumn{2}{c}{ V1 (Season-Wide) } \\
\cline { 2 - 3 } Capture & $\begin{array}{c}\text { Dam Passage } \\
\text { History }\end{array}$ & $\begin{array}{c}\text { BRZ-to-BRZ } \\
\text { Survival }\end{array}$ \\
\hline 111 & 5019 & 5019 \\
011 & 2 & 2 \\
101 & 4 & 5 \\
001 & 0 & 0 \\
120 & 0 & 0 \\
020 & 0 & 0 \\
110 & 312 & 312 \\
010 & 0 & 0 \\
200 & 0 & 0 \\
100 & 52 & 52 \\
000 & 337 & 352 \\
\hline Total & 5726 & 5742 \\
\hline
\end{tabular}

\begin{tabular}{ccc}
\hline & \multicolumn{2}{c}{ Season-Wide Dam Passage Survival } \\
\cline { 2 - 3 } Capture & $\mathrm{R} 2$ & $\mathrm{R} 3$ \\
\hline History & 919 & 923 \\
11 & 0 & 0 \\
01 & 0 & 0 \\
20 & 62 & 51 \\
10 & 5 & 9 \\
00 & 986 & 983 \\
\hline Total &
\end{tabular}


PNNL-22152

\section{Distribution}

No. of

Copies

\section{OFFSITE}

3 Brad Eppard

USACE Portland District

P.O. Box 2946

Portland, OR 97204

Mike Langeslay (PDF)

USACE Portland District

P.O. Box 2946

Portland, OR 97204

3 University of Washington

Columbia Basin Research

Puget Sound Plaza

$13254^{\text {th }}$ Avenue, Suite 1820

Seattle, WA 98101

ATTN: AG Seaburg

JR Skalski

RL Townsend
No. of

\section{Copies}

\section{ONSITE}

5 Pacific Northwest National Laboratory

$\begin{array}{lr}\text { Tom Carlson (PDF) } & \text { BPO } \\ \text { James Hughes } & \text { RCH } \\ \text { Gary Johnson } & \text { NBON } \\ \text { Gene Ploskey* } & \text { NBON } \\ \text { Steve Schlahta (PDF) } & \text { RCH } \\ \text { Mark Weiland } & \text { NBON } \\ \text { Christa Woodley } & \text { NBON } \\ \text { PNNL Information Release (PDF) } & \text { P8-55 }\end{array}$

*NBON copies sent to:

Gene Ploskey

390 Evergreen Drive

P.O. Box 241

North Bonneville, WA 98639 
US Army Corps

of Engineers

Prepared for the U.S. Army Corps of Engineers, Portland District,

under an Interagency Agreement with the U.S. Department of Energy

Contract DE-AC05-76RL01830

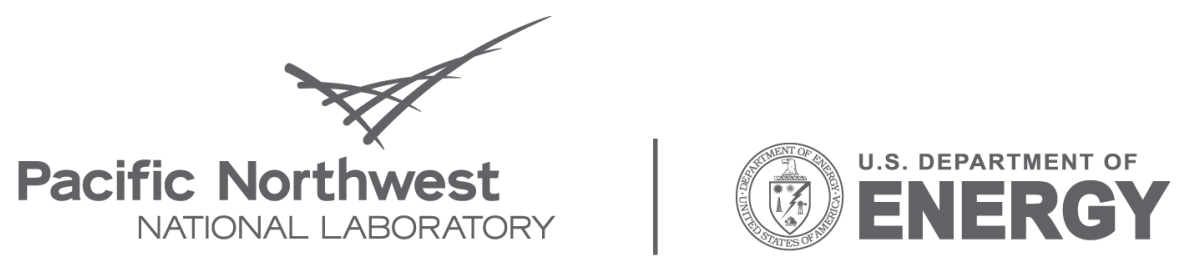

Proudly Operated by Battelle Since 1965

902 Battelle Boulevard

P.O. Box 999

Richland, WA 99352

1-888-375-PNNL (7665)

www.pnl.gov 